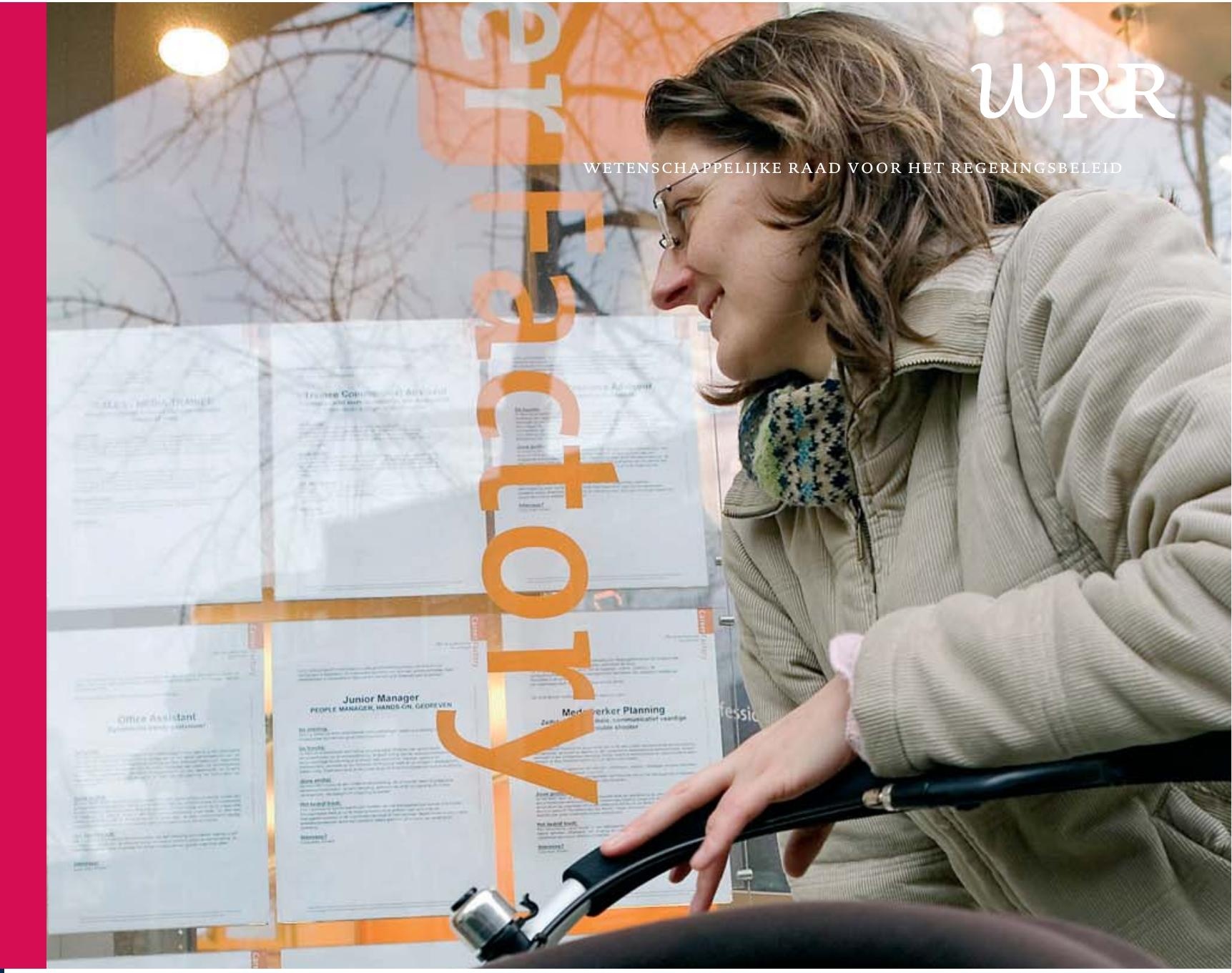

\title{
Investeren in werkzekerheid
}

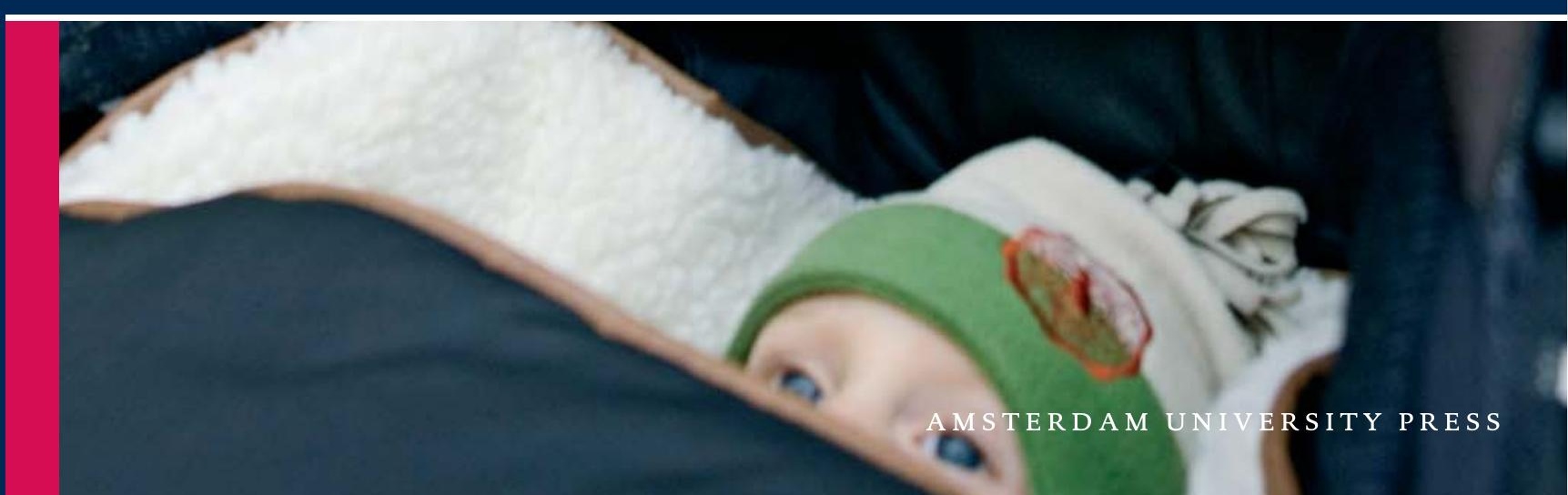


Investeren in werkzekerheid 
De Wetenschappelijke Raad voor het Regeringsbeleid werd in voorlopige vorm ingesteld in 1972. Bij wet van 30 juni 1976 (Stb. 413) is de positie van de raad definitief geregeld. De huidige zittingsperiode loopt tot 31 december 2007.

Ingevolge de wet heeft de raad tot taak ten behoeve van het regeringsbeleid wetenschappelijke informatie te verschaffen over ontwikkelingen die op langere termijn de samenleving kunnen beïnvloeden. De raad wordt geacht daarbij tijdig te wijzen op tegenstrijdigheden en te verwachten knelpunten en zich te richten op het formuleren van probleemstellingen ten aanzien van de grote beleidsvraagstukken, alsmede op het aangeven van beleidsalternatieven.

Volgens de wet stelt de WRR zijn eigen werkprogramma vast, na overleg met de minister-president die hiertoe de Raad van Ministers hoort.

De samenstelling van de raad is (tot 31 december 2007):

prof. dr. W.B.H.J. van de Donk (voorzitter)

mw. prof. dr. L. Hancher

prof. dr. P.A.H. van Lieshout

mw. prof. dr. P.L. Meurs

prof. dr. J.L.M. Pelkmans

drs. I.J. Schoonenboom

prof. dr. J.J.M. Theeuwes

prof. dr. P. Winsemius

Secretaris: prof. dr. A.C. Hemerijck

Plaatsvervangend secretaris: dr. R.J. Mulder

De WRR is gevestigd:

Lange Vijverberg 4-5

Postbus 20004

2500 EA Den Haag

Telefoon 070-356 46 oo

Telefax 070-356 4685

E-mailinfo@wrr.nl

Website http://www.wrr.nl 


\section{Investeren in werkzekerheid}


Omslagfoto: (C) WRR/Chantal Ariëns, Amsterdam

Omslagontwerp: Studio Daniëls, Den Haag

Vormgeving binnenwerk: Het Steen Typografie, Maarssen

ISBN 9789053567579

NUR $754 / 741$

(C) WRR/Amsterdam University Press, Den Haag/Amsterdam 2007

Alle rechten voorbehouden. Niets uit deze uitgave mag worden verveelvoudigd, opgeslagen in een geautomatiseerd gegevensbestand, of openbaar gemaakt, in enige vorm of op enige wijze, hetzij elektronisch, mechanisch, door fotokopieën, opnamen of enige andere manier, zonder voorafgaande schriftelijke toestemming van de uitgever.

Voor zover het maken van kopieën uit deze uitgave is toegestaan op grond van artikel 16B Auteurswet $1912 j^{\circ}$ het Besluit van 20 juni 1974, Stb. 351, zoals gewijzigd bij het Besluit van 23 augustus 1985, Stb. 471 en artikel 17 Auteurswet 1912, dient men de daarvoor wettelijk verschuldigde vergoedingen te voldoen aan de Stichting Reprorecht (Postbus 3051, $2130 \mathrm{~KB}$ Hoofddorp). Voor het overnemen van gedeelte(n) uit deze uitgave in bloemlezingen, readers en andere compilatiewerken (artikel 16 Auteurswet 1912) dient men zich tot de uitgever te wenden. 
Aan de Minister-president Voorzitter van de Ministerraad De heer mr.dr. J.P. Balkenende Postbus 20001

2500 EA Den Haag

ons kenmerk

2007004/wvdd/lt

\section{onderwerp}

WRR-rapport 77 'Investeren in werkzekerheid' doorkiesnummer 070-356 4691

email

voorzitter@wrr.nl telefax

070-356 4685

datum

12 januari 2007

Het doet mij genoegen $U$ hierbij het rapport 'Investeren in werkzekerheid' te mogen aanbieden. De arbeidsmarkt van de toekomst stelt hoge eisen aan werknemers. Om hen in staat te stellen ook in de toekomst het beste van hun loopbaan te maken, is het absoluut noodzakelijk dat de werkzekerheid van werknemers substantieel wordt versterkt. Dat vraagt om twee soorten van investeringen. Allereerst moeten werknemers meer dan ooit worden uitgedaagd in hun eigen kansen te investeren. Om hen daartoe in staat te stellen dienen de instituties van de arbeidsmarkt ook zelf op een meer toekomstbestendige wijze te worden ingericht: ook in die zin moet er worden geïnvesteerd in flexibiliteit en werkzekerheid. Bij die investeringen wordt ook van de werkgevers en de overheid het nodige gevraagd.

Nu de baanzekerheid van werknemers door uiteenlopende oorzaken geleidelijk minder absoluut wordt, en van hen meer flexibiliteit mag worden gevraagd, moet daar een ander soort van zekerheid tegenover komen te staan. Werkzekerheid, opgevat als het op positieve ervaringen gestoelde vertrouwen dat steeds wanneer daartoe aanleiding bestaat een andere functie of een andere baan bereikbaar is, biedt die zekerheid. Een dergelijke werkzekerheid vraagt om voldoende flexibiliteit op en van de arbeidsmarkt. Een flexibele arbeidsmarkt bevordert ook de productiviteitsontwikkeling en is een belangrijke voorwaarde voor de vergroting van de participatie. Een dergelijke toekomstbestendige herinrichting van de arbeidsmarktpolitiek vraagt om een cultuuromslag die vormgeeft aan instituties en arrangementen die in staat zijn de belangen van zekerheid en flexibiliteit op de arbeidsmarkt meer dan voorheen met elkaar in evenwicht te brengen.

Het rapport is gebaseerd op een onderzoek dat de Raad uitvoerde naar de flexibiliteit op de huidige Nederlandse arbeidsmarkt. Daarin wordt duidelijk dat een aantal groepen (zoals ouderen en allochtonen) en problematieken (zoals de verhouding tussen insiders en outsiders) op de arbeidsmarkt speciale aandacht vereisen.

Naar de mening van de raad vraagt een investering in werkzekerheid om een heroriëntatie van de bestaande instituties van het arbeidsmarktbeleid (cao's, re-integratie, ontslagrecht). Een toekomstgerichte herijking van de arbeidsmarktpolitiek vraagt ook om aandacht voor nieuwe risico's (combinatie van arbeid en zorg) en om een sterker accent op preventie en scholing.

Volgens de procedure van de instellingswet ziet de raad graag de reactie van de ministerraad tegemoet.

De voorzitter,

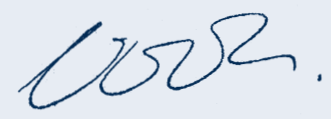

Prof.dr. W.B.H.J. van de Donk
De secretaris.

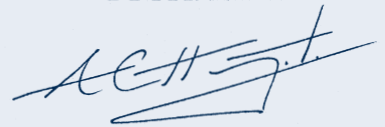

Prof.dr. A.C. Hemerijck 


\title{
INHOUDSOPGAVE
}

\author{
Samenvatting
}

I Flexibiliteit en zekerheid op de arbeidsmarkt 23

1.1 Richting en urgentie 23

1.2 Uitgangspunten voor een afweging 25

$\begin{array}{ll}\text { 1.2.1 Doelmatigheidselementen } & 26\end{array}$

$\begin{array}{ll}\text { 1.2.2 Rechtvaardigheidselementen } & 27\end{array}$

1.3 De transitionele arbeidsmarkt en werkzekerheid 30

$\begin{array}{ll}\text { 1.3.1 Drie centrale stromen } & 30\end{array}$

$\begin{array}{lll}\text { 1.3.2 Risicomanagement } & 32\end{array}$

$\begin{array}{ll}\text { 1.3.3 Drie zekerheden } & 33\end{array}$

1.4 Probleemstelling van het rapport 34

$2 \quad$ Internationale ontwikkelingen en vergelijkingen 37

$\begin{array}{lll}2.1 & \text { Inleiding } & 37\end{array}$

2.2 Externe ontwikkelingen 37

$2.3 \quad$ Internationale vergelijking 41

2.4 Het vermogen van arbeidsmarkten in de EU om de beroepsbevolking te laten participeren

2.5 Arbeidsproductiviteit en flexibele arbeidsrelaties 51

2.6 Aspecten van transities van baan naar baan 53

$\begin{array}{lll}2.7 & \text { Conclusies } & 58\end{array}$

$3 \quad$ Flexibiliteit op de externe arbeidsmarkt 59

$\begin{array}{lll}3.1 & \text { Inleiding } & 59\end{array}$

$\begin{array}{lll}3.2 & \text { Veranderingen van arbeidsmarktstatus } & 60\end{array}$

3.2.1 De transitionele arbeidsmarkt 60

3.2.2 Arbeidsmarktstromen en langdurige en herhalingswerkloosheid 62

$\begin{array}{lll}3.3 & \text { Baanwisselingen } & 63\end{array}$

$\begin{array}{lll}\text { 3.3.1 } & \text { Baancreatie en baandestructie } & 63\end{array}$

$\begin{array}{ll}3.3 .2 & \text { Onvrijwillige mobiliteit } \\ 3.3 .3 & 65\end{array}$

$\begin{array}{ll}3 \cdot 3 \cdot 3 \quad \text { Vrijwillige mobiliteit } & 67\end{array}$

3.4 Externe flexibiliteit en productiviteit $\quad 71$

3.4.1 Creatieve destructie als bron van productiviteitsstijging 71

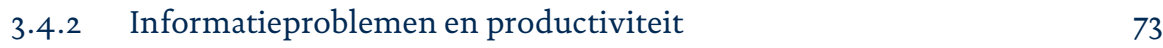

3.4.3 Externe flexibiliteit en de opbouw van human capital $\quad 74$

\begin{tabular}{ll}
3.4 .4 & Vastzitten in een baan \\
\hline
\end{tabular}

$\begin{array}{lll}3.5 & \text { Conclusies } & 76\end{array}$ 
$4 \quad$ Flexibiliteitsstrategieën van bedrijven en de interne arbeidsmarkt $\quad 77$

$\begin{array}{lll}4.1 & \text { Inleiding } & 77\end{array}$

4.2 Interne arbeidsmarkten $\quad 78$

4.3 De empirie van de interne arbeidsmarkt in Nederland $\quad 79$

4.3.1 Barsten in de baanzekerheid $\quad 79$

4.3.2 Kenmerken van de blijvers op de interne arbeidsmarkt $\quad 81$

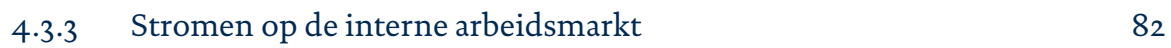

4.3.4 Het afnemend belang van interne arbeidsmarkten 84

4.4 Veranderingen op de interne arbeidsmarkt: functionele flexibiliteit 86

4.4.1 Individuele en collectieve arbeidsovereenkomsten 86

4.4.2 Investeren in mensen op de interne arbeidsmarkt 88

4.4.3 Naar een nieuw psychologisch contract? $\quad 89$

4.5 Transformatie van de interne arbeidsmarkt 90

$\begin{array}{ll}4.5 .1 & \text { Kern en periferie } 90\end{array}$

4.5.2 Outsourcing en offshoring 92

$\begin{array}{lll}4.6 & \text { Conclusies } & 93\end{array}$

$5 \quad$ Arbeidsmarktflexibiliteit, van buiten naar binnen en omgekeerd $\quad 97$

5.1 Inleiding $\quad 97$

5.2 Omvang van categorieën op de arbeidsmarkt $\quad 97$

5.3 Baanduur naar inkomen, leeftijd en geslacht 99

5.4 Vormen van externe mobiliteit: verschillen naar leeftijd, inkomen en
geslacht

5.4.1 Baanwisselingen 99

$\begin{array}{ll}\text { 5.4.2 Uittreden uit de arbeidsmarkt } & 106\end{array}$

$\begin{array}{lll}5.4 .3 & \text { Toetreden tot de arbeidsmarkt } & 107\end{array}$

$\begin{array}{lll}5.5 & \text { Specifieke groepen } & 108\end{array}$

$\begin{array}{lll}\text { 5.5.1 De specifieke positie van vrouwen } & 109\end{array}$

5.5.2 Autochtoon versus allochtoon 111

$\begin{array}{ll}5 \cdot 5 \cdot 3 \text { Mobiliteit van ouderen } & 113\end{array}$

$\begin{array}{lll}5.6 & \text { Conclusies } & 116\end{array}$

$6 \quad$ Flexibiliteit en sociaal-economische instituties $\quad 121$

$\begin{array}{lll}6.1 & \text { Inleiding } & 121\end{array}$

6.2 Ontslagbescherming 123

$\begin{array}{ll}\text { 6.2.1 Inleiding en beschrijving van de praktijk } & 123\end{array}$

$\begin{array}{ll}\text { 6.2.2 Sociaal-economische aspecten } & 125\end{array}$

$\begin{array}{ll}\text { 6.2.3 Arbeidsrelaties en ontslagbescherming } & 126\end{array}$

$\begin{array}{lll}6.2 .4 & \text { Knelpunten } & 127\end{array}$

$\begin{array}{ll}\text { 6.2.5 Slotopmerkingen } & 130\end{array}$

6.3 Het minimumloon 131

6.3.1 Inleiding 131

$\begin{array}{lll}\text { 6.3.2 Vraag- en aanbodverhoudingen } & 133\end{array}$

$\begin{array}{ll}\text { 6.3.3 Vergroting feitelijk aanbod } & 135\end{array}$

$\begin{array}{ll}\text { 6.3.4 Vergroting van de vraag } & 135\end{array}$

$\begin{array}{ll}6.3 .5 & \text { Slotopmerkingen } \\ & 136\end{array}$ 
$\begin{array}{lll}6.4 & \text { Activerend arbeidsmarktbeleid } & 137\end{array}$

$\begin{array}{lll}6.4 .1 & \text { Inleiding } & 137\end{array}$

$\begin{array}{lll}\text { 6.4.2 } & \text { Reïntegratie van uitkeringsontvangers } & 138\end{array}$

6.4.3 Recente ontwikkelingen 140

$\begin{array}{lll}6.4 .4 & \text { De effectiviteit } & 142\end{array}$

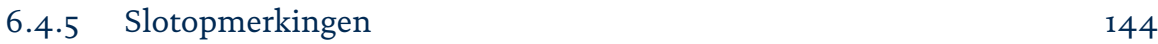

6.5 WW 145

$\begin{array}{ll}\text { 6.5.1 Inleiding } & 145\end{array}$

6.5.2 Knelpunten in de ww 146

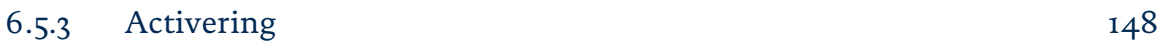

$\begin{array}{ll}6.5 .4 & \text { Sparen voor de ww }\end{array}$

6.5.5 Slotopmerkingen 150

6.6 Cao's 151

6.6.1 Inleiding 151

6.6.2 Ontwikkelingen in de Nederlandse cao's 152

6.6.3 Ontwikkelingen in Europa 154

6.6.4 De relatie tussen flexicurity en wetgeving $\quad 155$

6.6.5 Slotopmerkingen 156

$\begin{array}{lll}6.7 & \text { Concluderende opmerkingen } & 157\end{array}$

$7 \quad$ Hoofdlijnen van een toekomstbestendige arbeidsmarktpolitiek $\quad 161$

7.1 Investeren in werkzekerheid 161

7.2 Het bevorderen van werkzekerheid $\quad 164$

\begin{tabular}{ll} 
7.2.1 & Generieke uitgangspunten \\
\hline 7.2.2 & 164
\end{tabular}

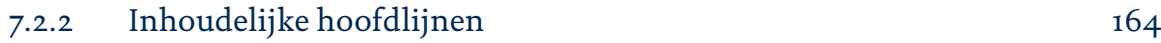

7.2.3 Investeren in levenslang leren en loopbaanregie $\quad 165$

7.2.4 Inkomensbescherming ten dienste van werkzekerheid 166

7.2.5 Bundeling van reïntegratie-inspanningen 166

$\begin{array}{ll}\text { 7.2.6 Een antwoord bieden voor de 'nieuwe risico's' } & 167\end{array}$

7.3 Werkzekerheid en de transities van functie naar functie 168

$\begin{array}{lll}\text { 7.3.1 Interne mobiliteit } & 168\end{array}$

$\begin{array}{ll}7 \cdot 3.2 & \text { Loopbaanperspectief } \\ 7 \cdot 3 \cdot 3 & 169\end{array}$

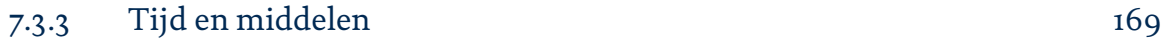

7.4 Werkzekerheid en de transitie van baan naar baan 171

7.4.1 Samenvoeging van inkomensbescherming en employability 171

7.4.2 Oriënteren, leren van reïntegreren 173

$\begin{array}{ll}\text { 7.4.3 Verankering van afspraken over employability } & 174\end{array}$

7.5 Werkzekerheid en de transities van buiten naar binnen $\quad 176$

$\begin{array}{lll}\text { 7.5.1 Oudere werknemers } & 176\end{array}$

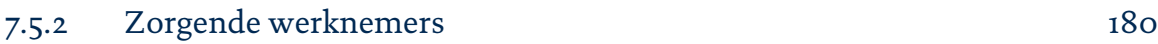

$\begin{array}{ll}\text { 7.5.3 Werknemers aan de onderkant } & 181\end{array}$

7.6 Het ontwikkelen van werkzekerheid als leerproces $\quad 184$

$\begin{array}{lll}\text { 7.6.1 Cultuurveranderingen } & 184\end{array}$

$\begin{array}{lll}\text { 7.6.2 'Nieuwe risico's' } & 185\end{array}$

7.6.3 Aanpassingen in de arbeidsorganisatie en het arbeidsvoorwaardenoverleg 
$\begin{array}{lll}\text { 7.6.4 Een ingroeimodel als overgangsfase } & 187\end{array}$

$\begin{array}{ll}\text { 7.6.5 De essentie van werkzekerheid } & 189\end{array}$

$\begin{array}{ll}\text { Literatuur } & 193\end{array}$

Bijlagen

$\begin{array}{lll}\text { Bijlage } 1 & \text { Flexibiliteit en zekerheid } & 201\end{array}$

$\begin{array}{lll}\text { Bijlage } 2 & \text { HRM-gesprekken } & 202\end{array}$

Bijlage $3 \quad$ Overzicht van het arbeidsmarktbeleid in Nederland 203 


\section{SAMENVATTING}

\section{Het investeren in werkzekerheid als nieuwe ambitie van toekomstbestendig arbeidsmarktbeleid}

De arbeidsmarkt verandert. De demografische ontwikkelingen leiden ertoe dat regelmatig perioden van krapte op de arbeidsmarkt zullen ontstaan. Tegelijkertijd hebben bedrijven in een toekomstige economische orde meer behoefte aan een grotere flexibiliteit van arbeid. In het zo ontstane klimaat is ruimte voor een herijking van de flexibiliteit en de zekerheidsarrangementen op de arbeidsmarkt. De raad heeft onderzoek gedaan naar de feitelijke stromen op de arbeidsmarkt zoals die blijken uit het Sociaal Statistisch Bestand van het Centraal Bureau voor de Statistiek. De raad komt zo tot een genuanceerd beeld van de mobiliteit op de Nederlandse arbeidsmarkt en geeft daarmee een aanvulling op de inzichten in de toekomst van de arbeidsmarkt die vanuit een overzicht van de relevante omgevingsfactoren ontstaan. Er valt, zo blijkt uit het onderzoek dat de raad heeft gedaan naar de veranderende vraag- en aanbodverhoudingen op de arbeidsmarkt door institutionele vernieuwing, voor meerdere partijen winst te behalen: werkgevers en werknemers, insiders en outsiders, jong en oud, man en vrouw. In dit rapport doet de raad onder de noemer van werkzekerheid voorstellen om flexibiliteit en zekerheid op de arbeidsmarkt op een andere leest te schoeien.

Arbeidsmarktbeleid neemt in belang toe. Arbeidsmarktbeleid is een van de weinig overgebleven velden waar nationaal beleid van doorslaggevende betekenis is.

Institutionele vernieuwing op de arbeidsmarkt is een normatief geladen onderwerp. De inzet is om de doelmatigheid van de arrangementen op de arbeidsmarkt te versterken op een wijze die ook op een breed draagvlak kan rekenen en aan in ruime kring aanvaarde rechtvaardigheidsoverwegingen voldoet. De raad maakt duidelijk welke normatieve uitgangspunten hij hanteert. Deze sluiten aan bij de rechtvaardigheidstheorie van Sen (1999) die met het oog op gelijke kansen voor ontwikkeling de nadruk legt op de vrijheid en de toerusting om te handelen. In het verband van de arbeidsmarkt houdt dat in dat individuen (personen) worden aangesproken óp en tegemoetgekomen ín het onderhoud en de versterking van hun vaardigheid om naar vermogen te participeren. Rechtvaardigheid opgevat in deze zin gaat eerder samen met doelmatigheid dan dat het daarmee strijdig is. Kansengelijkheid komt ten goede aan de soepele werking van de arbeidsmarkt, leidt ertoe dat meer mensen op de juiste plek belanden en verhoogt de participatie.

Het centrale begrip in dit rapport is werkzekerheid. Hieronder wordt verstaan dat individuen een op ervaringen gestoeld vertrouwen hebben dat zij wanneer daartoe aanleiding bestaat bij hun werkgever in een andere functie of bij een andere werkgever in een andere baan hun loopbaan kunnen vervolgen. Werkzekerheid houdt ook in dat personen die (tijdelijk) buiten het arbeidsproces staan vertrouwen kunnen hebben in de mogelijkheid om op de arbeidsmarkt te kunnen instromen. De raad meent dat de institutionele condities waaronder werkzekerheid kan 
bestaan, vragen om een toekomstbestendige herijking van de bestaande instituties.

\section{Urgentie van werkzekerheid}

Het versterken van werkzekerheid is urgent. Er is een complex van factoren dat ertoe leidt dat de baanzekerheid afneemt, zoals de internationalisering van de financiële en productmarkten al dan niet in samenhang met ontwikkelingen in EU-verband, de technologische vooruitgang en de organisatorische verandering en ontwikkelingen op HRM-gebied. Toenemende concurrentie en korter wordende omlooptijden van producten en diensten zetten druk op functieduur en baanduur. Ook de demografische ontwikkelingen zijn een reden om werkzekerheid tot speerpunt van sociaal-economisch beleid te maken. De beroepsbevolking veroudert mede vanwege de trend (en noodzaak) om langer door te werken. In dat licht is een versterkte aandacht voor het onderhoud van arbeidsvaardigheden over de levensloop van groot belang. Ook de normalisering van de combinatie van arbeid en zorg en van de combinatie van arbeid en opleiding nopen tot aandacht voor werkzekerheid.

De Nederlandse arbeidsmarkt ontwikkelt zich in vergelijking met de arbeidsmarkt in andere EU-lidstaten niet ongunstig. In vrijwel alle landen van de EU spelen de genoemde ontwikkelingen. Het absorptievermogen van de Nederlandse arbeidsmarkt is de afgelopen tien jaar verbeterd, zij het dat veel arbeid in deeltijd plaatsvindt en dat ouderen, laagopgeleiden en vrouwen nog steeds minder participeren dan gemiddeld. De arbeidsmobiliteit bevindt zich op een gemiddeld niveau. Uitkeringsontvangers weten echter maar moeizaam de weg terug naar de arbeidsmarkt te vinden. Waarnemingen van personen die van het ene jaar op het andere jaar in een uitkeringssituatie zitten, duiden niet alleen op langdurige werkloosheid maar ook op herhalingswerkloosheid. De productiviteitsontwikkeling ligt op een gemiddeld EU-niveau, maar duidelijk onder dat van andere OESO-lidstaten.

\section{Arbeidsmarktflexibiliteit}

Op de arbeidsmarkt is de nodige beweging zowel wat betreft banen als wat betreft personen. Uit het Sociaal Statistisch Bestand van het Centraal Bureau voor de Statistiek komt naar voren dat over de periode van 1999 tot 2003 jaarlijks gemiddeld 9 procent van het totaal aantal banen nieuw werd geschapen en 8 procent werd vernietigd. In bedrijven waar het aantal banen kromp, vloeiden werknemers af, maar stroomden tegelijkertijd ook werknemers toe. Werknemers die hun baan verloren stroomden in hoogconjunctuurjaren (1999-2000) meer door naar andere banen dan in laagconjunctuurjaren (2002-2003). Het blijkt verder dat baanwisselingen in het eerste deel van de loopbaan overwegend opwaartse mobiliteit met zich meebrachten en in het tweede deel van de loopbaan overwegend neerwaartse mobiliteit. In hoogconjunctuurjaren wisten meer personen vanuit een uitkeringssituatie een baan te bemachtigen dan in laagconjunctuurjaren. Op basis van Amerikaans onderzoek valt te concluderen dat de schepping en vernietiging van banen via de groei van de productievere bedrijven 
en de krimp van de minder productieve bedrijven goed is voor ongeveer de helft van de productiviteitsstijging. Er is dus nogal wat externe flexibiliteit op de arbeidsmarkt en deze leidt per saldo tot groei, maar vormt door de mogelijkheid van neerwaartse mobiliteit ook een bron van onzekerheid.

Ook op interne arbeidsmarkten binnen bedrijven is de nodige beweging. De mobiliteit van functie naar functie binnen hetzelfde bedrijf is geschat op ongeveer 4 procent van het aantal banen. Binnen grote bedrijven zijn de mogelijkheden voor interne mobiliteit groter en is ook minder externe mobiliteit. Van de 7,2 miljoen werknemers werken er 5,2 miljoen in bedrijven met meer dan 50 werknemers. De gemiddelde baanduur ligt al jaren iets boven 9 jaar. Dat betekent dat grote groepen langdurige dienstverbanden hebben. De gemiddelde functieduur is uiteraard korter en ligt op 6 jaar. De externe mobiliteit in de tweede helft van de loopbaan is laag. Veel oudere werknemers blijven zitten waar ze zitten. Ondanks verschillen tussen feitelijke en gewenste baankenmerken is er weinig zoekgedrag. Er dreigt het risico van een mid-career impasse. Dit probleem zal vanwege de vergrijzing van de beroepsbevolking vaker voorkomen. Gegeven de externe structurele veranderingen ligt het niet voor de hand dat 'de baan voor het leven' ook in de toekomst nog een lang leven beschoren zal zijn. Het is, integendeel, zeer waarschijnlijk dat steeds meer werknemers ook in de tweede helft van hun loopbaan meer en meer baanwisselingen zullen meemaken.

Een belangrijke vraag is wat de mogelijkheden en de beperkingen zijn om werknemers tot interne flexibiliteit te bewegen. Er ontwikkelt zich geleidelijk aan een rechtsnorm van 'goed werknemerschap' die werknemers verplicht tot medewerking aan functionele flexibiliteit. Binnen cao's worden steeds vaker afspraken gemaakt over functionele flexibiliteit en ook over opleiding. Er zit echter nog veel ruimte tussen wat in het overleg tussen de sociale partners wordt afgesproken en de praktijk. Vooral ten aanzien van oudere werknemers bestaat er nog veel achterstallig onderhoud waardoor de inzetbaarheid van deze groep minder is dan mogelijk zou (moeten) zijn.

In de afgelopen decennia is in grotere arbeidsorganisaties een praktijk gegroeid waarbij rond een kern van vaste medewerkers een schil van tijdelijke medewerkers hangt waarvoor contractflexibiliteit bestaat. Na een aantal jaren van groei lijkt het aandeel van deze flexwerkers nu stabiel te blijven, maar voor de toekomst is het, vooral gezien de ontwikkelingen binnen arbeidsorganisaties, niet onmogelijk dat het aandeel van flexwerkers verder zal groeien.

\section{Specifieke groepen}

Uit het onderzoek op basis van het Sociaal Statistisch Bestand van het Centraal Bureau voor de Statistiek(CBS) komt naar voren dat er sterke verschillen bestaan in de positie die specifieke groepen op de arbeidsmarkt innemen. Oudere werknemers, vrouwen en lager opgeleiden hebben in de regel een zwakkere arbeidsmarktpositie. Allochtone werknemers zijn meer dan gemiddeld lager opgeleid en ondervinden bovendien nadeel van hun afkomst. 
Oudere werknemers zijn in de regel veel minder mobiel dan jongere werknemers. Mobiliteit op latere leeftijd is veelal gedwongen en leidt vaak tot uittreding uit de arbeidsmarkt. Recentelijk is de financiële aantrekkelijkheid van de meeste routes voor vervroegde uittreding sterk verminderd. Uittreding uit de arbeidsmarkt is daardoor minder een optie dan voorheen, terwijl werkgevers weinig geneigd zijn om oudere werknemers in dienst te nemen. De hoogte van de loonsom vormt daarvoor een belangrijke belemmering. Ook leeftijdsdiscriminatie speelt een rol.

Werknemers die na de geboorte van een kind arbeid en zorg gaan combineren, veelal vrouwen, verkiezen om in deeltijd te gaan werken of geheel uit te treden. Nadat men 'uit de kinderen' is, bestaat er een voorkeur om weer te gaan werken of om meer uren te gaan werken. Herintreding op de arbeidsmarkt blijkt dan lastig te zijn en de periode van deeltijdwerk waarin arbeid en zorg werden gecombineerd, beïnvloedt de loopbaankansen in negatieve zin.

Allochtone werknemers hebben minder dan autochtone werknemers een stabiele arbeidsrelatie en een vaste baan. Naast lagere opleidingen spelen hier mogelijk ook andere belemmeringen een rol waaronder beperkte taalvaardigheid en discriminatie.

\section{Arbeidsmarktinstrumenten}

Arbeidsmarktbeleid is van invloed op de participatie op de arbeidsmarkt en op de transities die op de arbeidsmarkt gemaakt worden. Een vijftal arbeidsmarktinstrumenten is in dit rapport afzonderlijk beschreven: ontslagbescherming, minimumloon, activerend arbeidsmarktbeleid, werkloosheidwetgeving en cao's.

Het huidige duale stelsel van ontslagrecht lijkt als regel geen uitzonderlijke problemen op te leveren. Voor de relatief kleine categorie van ontslagen wegens persoonlijke reden lijken die problemen zich wel voor te doen. Op het totale aantal beëindigingen is dit een relatief kleine categorie. Aan de ene kant zijn er problemen met de veeleisende procedure via het CWI, aan de andere kant worden de door de kantonrechter toegekende ontslagvergoedingen soms als buitensporig ervaren.

Een verlaging van het minimumloon zal naar verwachting weinig extra participatie van laagopgeleiden opleveren. Wel zullen negatieve effecten gaan overheersen. Een goed alternatief om de participatie van laagopgeleiden te verhogen grijpt aan op het opleidingsniveau. In het bijzonder van leren in de context van het werk valt nog veel te verwachten.

In het arbeidsmarktbeleid is steeds meer aandacht komen te liggen op reïntegratietrajecten om de transitie naar een baan te bespoedigen. Reïntegratie aangevuld met sanctionering van oneigenlijk gebruik van uitkeringen kan effectief zijn. Bij de invulling van reïntegratietrajecten is aanbod van scholing minder effectief dan het bieden van inspraak aan de uitkeringstrekker over de vormgeving van zijn reïntegratie. Ook de overstap naar resultaatfinanciering heeft zijn vruchten afgeworpen, zij het dat verdere differentiatie in contractuele inspanningen van het 
reïntegratiebedrijf noodzakelijk is om ook de groep van moeilijk bemiddelbare werknemers te bedienen.

Met betrekking tot verbeteringen in de ww gaat de aandacht uit naar de beteugeling van oneigenlijk gebruik. Dergelijk gebruik kan tot uitdrukking komen in een grotere instroom, een geringere uitstroom en een hogere gebruiksfrequentie. De instroom is in te perken door de werkzekerheid te vergroten. De regulering van de instroom kan niet los gezien worden van het ontslagrecht. Er is in dit opzicht wat te bereiken door aan beëindiging van een arbeidsrelatie begeleiding naar een andere baan te koppelen. Dit is ook het geëigende middel om de verblijfsduur in de ww te beperken. Sanctiebeleid werkt vooral ter bestrijding van evident misbruik van uitkeringsregelingen.

In de loop van de tijd zijn andere onderwerpen dan de loonontwikkeling deel gaan uitmaken van het arbeidsvoorwaardenoverleg. Vergroting van de flexibiliteit in samenhang met de vergroting van de werkzekerheid van werknemers is het oogmerk van de nieuwe cao-bepalingen. Deze spitsen zich toe op voorwaarden voor een soepele werking van de arbeidsmarkt, op het bevorderen van employability (inzetbaarheid) en daarbij in het bijzonder op scholingsinstrumenten. Aan een feitelijke invulling van deze afspraken wil het in de praktijk nog weleens ontbreken, terwijl scholing in de meeste gevallen verbonden is met de bestaande baan. Er is weinig toename te bespeuren in de invulling van employability bevorderende afspraken. Toename is er bij interne loopbaanbegeleiding door opleidingsplannen, functioneringsgesprekken en dergelijke.

\section{Versterking van werkzekerheid}

Werkzekerheid kan in belangrijke mate met het huidige arbeidsmarktinstrumentarium vormgegeven worden. Daarvoor moeten deze instrumenten wel beter op elkaar afgestemd worden. Ook is het nodig om afzonderlijke instrumenten beter in te richten op het bereiken van werkzekerheid. Herschikkingen zijn wenselijk op een viertal terreinen:

- een leven lang leren;

- inkomensbescherming;

- reïntegratiebeleid;

- 'nieuwe risico's'.

De inspanningen op deze terreinen moeten (beter) worden afgestemd op het verwezenlijken van inzetbaarheid van individuele werknemers. Opleiding in het kader van een leven lang leren is thans overwegend gericht op de huidige functie en niet op andere functies bij dezelfde werkgever of nieuwe banen bij andere werkgevers. Inkomensbescherming heeft een te sterk 'beschermend' accent en de middelen hiervoor kunnen nu nog maar ten dele activerend worden aangewend voor het investeren in werkzekerheid. Op het terrein van het reïntegratiebeleid is veel bereikt, maar inspanningen van de verschillende partijen staan soms, qua timing en richting, los van elkaar. Ten slotte worden de nieuwe risico's, die samenhangen met het combineren van arbeid en zorg en met de hogere participa- 
tie van oudere werknemers, stiefmoederlijk behandeld in vergelijking met de klassieke risico's waarop wW, WAO en bijstand betrekking hebben. De raad meent dat een perspectiefvolle betekenis aan werkzekerheid kan worden gegeven door de oriëntatie op al deze terreinen te kantelen. Het arbeidsmarktbeleid kan veel winnen bij een activerende op de toekomstige loopbaan gerichte oriëntatie. In technische zin volstaan hiervoor bijstellingen van het instrumentarium op elk van de genoemde terreinen.

Investeren in werkzekerheid betekent ook de mogelijkheid verschaffen om nieuwe vaardigheden te verwerven. Deze vaardigheden kunnen van tweeërlei aard zijn: nieuwe vaardigheden als de bestaande verouderen of eenzijdig zijn en basale vaardigheden als het huidige niveau van productiviteit ontoereikend is.

Dit laatste betreft vooral mensen in de bijstand. Inkomensbescherming omzetten in investeringen in vaardigheden betekent hier dat kan worden vastgehouden aan het minimumloon. Investeren in vaardigheden verbetert de arbeidsmarktperspectieven van laagopgeleiden. Een verlaging van het minimumloon onder het sociaal minimum zal niet leiden tot meer inschakeling van laagopgeleiden.

In plaats van een neerwaartse aanpassing van het loonpeil bepleit de WRR het inzetten op een opwaartse aanpassing van het opleidingsniveau. De implicatie van deze keuze is dat voor deze groep meer ambitieuze integratie-inspanningen beschikbaar moeten komen.

Met betrekking tot investeren in werkzekerheid kan onderscheid worden gemaakt naar de drie hoofdvormen van transities van dit rapport.

Om de stap van functie naar functie te vergemakkelijken, bepleit de raad expliciete aandacht voor de loopbaanperspectieven van elke werknemer. Deze perspectieven dienen te worden belegd met scholingsfaciliteiten, waarbij scholing ook gericht is op een volgende functie en niet alleen op de huidige. Het uitstippelen van de gewenste loopbaan behoort primair tot de verantwoordelijkheid van de werknemer. Maar de ontwikkeling ervan vergt tijd en middelen die beschikbaar moeten worden gesteld, bijvoorbeeld in de vorm van een persoonlijk opleidingsbudget of persoonlijke leerrechten.

Met betrekking tot de overgang van baan naar baan constateert de WRR dat er bij gedwongen ontslag drie concurrerende vormen van inkomensbescherming zijn (loon gedurende opzegtermijn, ontslagvergoeding en ww), waarvan alleen de Ww mede gericht is op het verwerven van vaardigheden. Door de loondoorbetaling en de ontslagvergoeding om te zetten in een actieve zoekperiode (waarvan de lengte varieert met het arbeidsverleden) en door de reïntegratie-inspanningen van werknemer, werkgever en overheid gebundeld naar voren te halen, wordt de kans op het vinden van een nieuwe baan gemaximeerd.Als in de cao overeenstemming is bereikt over een adequate invulling van de inspanningen gedurende de zoekperiode die aan het ontslag voorafgaat, en er ook duidelijkheid is over het aangekondigde ontslag en over de duur van die zoekperiode, vervalt de reden om 
de ontslagverlening door tussenkomst van CWI of kantonrechter te laten goedkeuren. Ten behoeve van werknemers zonder cao kunnen de hoofdbestanddelen van deze cao-afspraken vervolgens in een kaderwet worden neergelegd. Deze reïntegratie-inspanningen moeten in het verlengde liggen van de scholingsactiviteiten die horen bij het loopbaanperspectief. Invullingen in cao's van de inspanningen zal daarom niet in een keer definitief kunnen worden geregeld. Het gaat om een wezenlijke breuk met traditionele vormen van het arbeidsbestel. Dit zal de nodige innovatie vergen. Om ervaring op te doen bepleit de WRR dan ook dit model in eerste aanleg toe te passen op de ontslagen vanwege het persoonlijke functioneren (verwijtbaar gedrag, disfunctioneren, verstoorde arbeidsrelatie). In de praktijk blijkt deze ontslaggrond veruit de meeste problemen op te leveren.

Voor de transitie van outsider naar insider spitst de raad toe op drie groepen met een kwetsbare arbeidsmarktpositie: allochtonen, zorgende werknemers en ouderen. Investeren in werkzekerheid betekent niet dat alleen maar aan louter cognitieve vaardigheden aandacht wordt besteed. Er is juist een duidelijke ontwikkeling gaande waarbij andere dan technische en intellectuele vaardigheden als essentieel worden beschouwd voor het succesvol uitoefenen van een baan, zoals ambitie, motivatie, integriteit, collegialiteit en loyaliteit. Ook daarin kunnen cursussen en opleidingen voorzien, wanneer men bewust is van leerwensen op deze punten. De stimulering van het zelfstandig ondernemerschap biedt eveneens perspectieven. Voor allochtonen kunnen specifieke leerwensen een rol spelen, zoals onder meer taalvaardigheden. Maar ook wordt een streng antidiscriminatiebeleid bepleit.

Investeringen in vaardigheden kunnen ook de mogelijkheden betreffen die mensen in staat stellen om bij wijzigingen in de persoonlijke omstandigheden toch te kunnen blijven functioneren. $\mathrm{Nu}$ is het zo dat het combineren van arbeid en zorg en ook het bereiken van een leeftijd hoger dan 55 of 60 jaar er niet zelden toe leidt dat de loopbaan wordt afgebroken. Voor zorgende werknemers bepleit de raad in lijn met het recente rapport over de verzorgingsstaat een verruiming van het zorgverlof en de vormgeving van kinderopvang als basisvoorziening. Voor oudere werknemers zal de hierboven aanbevolen aanpak gericht op het ontwikkelen van een loopbaanperspectief alsmede het leven lang leren als uitvloeisel daarvan, vruchten afwerpen. Op korte termijn zal dit voor de huidige generatie oudere werknemers nog weinig soelaas kunnen bieden, zodat voor deze categorie een fiscale tegemoetkoming wordt bepleit die hen in staat stelt om zonder inkomensverlies of vier dagen te werken of vijf dagen tegen een lager brutoloon. Daarnaast blijft aandacht nodig voor leeftijdsdiscriminatie.

De raad meent dat de hier voorgestelde institutionele bijstellingen zich goed laten inpassen in de wijzigingen die het Nederlandse arbeidsbestel gedurig ondergaat. Tegelijk mogen de culturele vereisten voor een succesvolle toepassing niet worden onderschat. Door ten principale in te zetten op werkzekerheid zullen de beschikbare financiële middelen in plaats van curatief voor inkomensbescherming, meer en meer preventief voor het verwerven van vaardigheden moeten worden aangewend. Door meer accent te leggen op de nieuwe risico's kan de 
overheid een verdere bijdrage leveren aan het bewerkstelligen van werkzekerheid. Voor werknemers en werkgevers betekent dit ook een omslag, omdat de focus op de bestaande baan in de huidige arbeidsmarkt steeds minder kansrijk is.

Bij de arbeidsongeschiktheid heeft de SER ervoor gekozen dat "het activeren van beschikbare arbeidsgeschiktheid voorrang krijgt op het verzekeren van arbeidsongeschiktheid". In lijn hiermee wordt hier bepleit om ook voorrang te geven aan de geschiktheid voor een nieuwe baan, in plaats van het compenseren van de ongeschiktheid van een oude baan. 




\section{TEN GELEIDE}

Dit rapport is voorbereid door een interne projectgroep van de WRR. Voorzitter was prof. dr. J.J.M. Theeuwes, lid van de raad. Verder bestond deze projectgroep ten tijde van de voltooiing van het rapport uit de volgende stafleden: prof.dr. Anton Hemerijck, drs. Paul van Leeuwe, dr. Dirk Scheele (projectcoördinator) en dr. Gerard de Vries. In een eerder stadium hebben Cindy Kroon, dr. Rob Mulder, dr. Paul Tang en Tijl Woortman van de projectgroep deel uitgemaakt. De eindredactie was mede in handen van mr. Jan de Pree.

Voor de voorbereiding van dit rapport is dankbaar gebruikgemaakt van statistisch materiaal afkomstig uit het Sociaal Statistisch Bestand van het Centraal Bureau voor de Statistiek. Op basis van dit rijke materiaal kon met name in de hoofdstukken 3 en 5 een goed beeld gegeven worden van de mobiliteit op de Nederlandse arbeidsmarkt.

Ten behoeve van de samenstelling van dit rapport zijn verder een aantal externe onderzoeken gedaan. Deze onderzoeken zijn gepubliceerd in een bundel die gelijk met dit rapport verschijnt: D. Scheele, J.J.M. Theeuwes en G.J.M. de Vries (red.), Arbeidsflexibiliteit en ontslagrecht, WRR-Verkenning 14, Amsterdam: Amsterdam University Press. In deze verkenning zijn bijdragen opgenomen van mr. Alexandra Baris, dr. Michèle Belot, drs. Arie Gelderblom, prof. dr. Jaap de Koning, dr. Marc van der Meer, prof. dr. Jan van Ours, mr. Ann-Sophie Vandenberghe, prof. mr. Evert Verhulp en prof. dr. Jelle Visser.

De projectgroep heeft zeer kunnen profiteren van een serie interviews die gevoerd zijn met verantwoordelijken voor het personeelsbeleid in een aantal grote bedrijven en instellingen. De namen van de geïnterviewde personen zijn te vinden in een bijlage van dit rapport.

Bij de voorbereiding is bovendien gebruikgemaakt van suggesties en commentaar van prof. dr. P.T. de Beer, prof. dr. J. Hartog, dr. R. Huiskamp, drs. E. Jongen, dr. M.J.M. Kerkhofs, dr. ir. P. Kooiman, dr. W. Salverda, ir. C.W.J. Wevers en prof. dr. T. Wilthagen. De raad is hen allen erkentelijk voor hun bijdrage. Voor de inhoud van dit rapport is alleen de raad verantwoordelijk. 


\section{FLEXIBILITEIT EN ZEKERHEID OP DE ARBEIDSMARKT}

\subsection{RICHTING EN URGENTIE}

Economische, technologische en demografische ontwikkelingen stellen nieuwe en hoge eisen aan de werking van de arbeidsmarkt. Verwacht wordt bovendien dat de arbeidsmarkt in de volgende decennia te kampen zal hebben met een lage of zelfs negatieve groei van het arbeidsaanbod in combinatie met een trendmatig normale, positieve groei van de vraag naar arbeid. Er zijn niet genoeg nieuwe toetreders ter vervanging van de uittreders. De arbeidsmarkt wordt dan gespannen en zal in een oplopende conjunctuur al vrij snel tekorten vertonen. Dat betekent dat in de toekomst situaties van lage werkloosheid en veel openstaande vacatures relatief vaak kunnen voorkomen. Als we er niet in slagen arbeidsmarkttransities te vergemakkelijken, zal het vraagoverschot naar arbeid uitmonden in knelpunten, vooral op deelmarkten van de arbeidsmarkt en daarmee in spanningen in het loongebouw. Die spanningen zullen dan resulteren in hogere lonen dan de productiviteit rechtvaardigt en (dus) uiteindelijk in lagere groei. De hogere lonen zullen tot meer inflatie leiden en de onvervulde vacatures tot minder banen, een combinatie die een ernstige stagnering kan inhouden. Een dergelijke aantasting van het economische draagvlak is ongewenst.

Om onder de geschetste omstandigheden de spanning op de arbeidsmarkt zo laag mogelijk te doen zijn is een optimale allocatie van de factor arbeid noodzakelijk. Om hiertoe te komen is het in de eerste plaats gewenst dat de arbeidsmarkt flexibel is, zodat de kans dat werknemers daar werken waar hun productiviteit optimaal is. In de tweede plaats is het van belang dat de arbeidsparticipatie in kwantitatieve zin maximaal is, dat wie kan werken ook daadwerkelijk aan het arbeidsproces deelneemt.

Dit rapport richt zich in het bijzonder op vergroting van de arbeidsmarktflexibiliteit, als instrument om tot optimale allocatie te komen, zodat de samenleving als geheel profiteert van de eruit voortvloeiende productiviteitswinst en economische groei. Zo gesteld is het een verandering waar niemand op tegen zou kunnen zijn. De partijen op de arbeidsmarkt hebben hierbij echter uiteenlopende, en soms ook tegenstrijdige belangen. Werkgevers hebben belang bij een flexibele inzet van arbeid, maar willen ook vasthouden aan ervaren en gemotiveerde werknemers. Zodra aan de andere kant de flexibiliteit van arbeid wordt opgerakeld, vrezen werknemers voor willekeur en de teloorgang van hun baan. Echter, het merendeel van de werknemers is vrijwillig mobiel en betere arbeidsvoorwaarden bij andere werkgevers worden gretig opgezocht. Voor sommigen zijn baanwisselingen tijdens de loopbaan de ideale manier om vooruit te komen, anderen komen moeilijk los uit een opeenvolging van onbevredigende flexibele banen afgewisseld met werkloosheidsperiodes. Wat hiervan precies zij, het is een gegeven dat grotere flexibiliteit onder de huidige institutionele omstandigheden voor 
werknemers ingrijpende consequenties kan hebben. Het bezit van een baan en een daaraan gekoppeld inkomen op een redelijk niveau is voor hen essentieel. Flexibiliteit moet daarom, willen de sociale verhoudingen niet ingrijpend verstoord worden, vergezeld gaan van reële kansen voor werknemers om zich op de arbeidsmarkt staande te houden. Er zal niet primair compensatie gezocht moeten worden in de sociale voorzieningen en de inkomenszekerheid die zij bieden: dat zou de ook beoogde maximale inzet van het arbeidspotentieel ondergraven, en, belangrijker, aan de betrokkenen de kans op maatschappelijke participatie via het werk ontzeggen.

Waar daarentegen vooral op gemikt moet worden is werkzekerheid, althans op sterke vergroting van de kans voor werknemers om op grond van hun capaciteiten steeds een arbeidsplaats te kunnen vinden. Alleen dan is ook vergroting van de flexibiliteit te rechtvaardigen. De hiervoor noodzakelijke versterking van de vaardigheden en de employability van de werknemers vereist naast hun eigen inzet ook een belangrijke bijdrage van de werkgever(s) en van de overheid. Als, na een met goede waarborgen omkleed overgangsproces, bij alle betrokkenen 'de knop omgedraaid' zal zijn, zal de stabielere economische groei die eruit voortvloeit een beloning zijn waar ieder van profiteert.

De ontwikkelingen die tot grotere flexibiliteit op de arbeidsmarkt dwingen zijn niet nieuw. Zowel in de economische werkelijkheid als in het publieke debat laten zij al langer hun sporen achter.

De vaak geuite vrees dat de 'baan voor het leven' is verdwenen verwijst naar de onzekerheid die samenhangt met een groter aantal baanwisselingen. Door reorganisaties, product- en procesvernieuwingen en kostenbesparingen is de inhoud en verdeling van functies binnen eenzelfde bedrijf voortdurend in beweging. De externe en de interne arbeidsmarkt bieden minder zekerheid voor de insider dan vroeger. Nog minder zeker is de positie van de outsiders, personen die buiten de arbeidsmarkt staan, die werkloos zijn of slechts voor onregelmatige en irreguliere baantjes in aanmerking komen.

In paragraaf 1.3 wordt kort ingegaan op de theorie van de transitionele arbeidsmarkt, die een kader biedt voor analyse van de verschillende stromen op de arbeidsmarkt. De plaats, de stromen van baan naar baan, van functie naar functie en van outsider naar insider, die in de analyses in de verdere hoofdstukken centraal staan, wordt daarin verder verduidelijkt.

In het debat blijkt vooral dat het bij flexibiliteit niet alleen om economische doelmatigheid gaat. Flexibiliteit grijpt diep in het raderwerk van de arbeidsmarkt en de samenleving. Daarom gaat een debat over arbeidsmarktflexibiliteit over veel meer dan een herziening van de ontslagregeling of een bijstelling van de wet flexibiliteit en zekerheid. Het gaat ook over de hoogte van het minimumloon, de inrichting van de cao, de activerende werking van de sociale verzekering, het op peil krijgen en houden van kennis en vaardigheden, verlofregelingen, en de 
kwaliteit en de toegankelijkheid van de maatschappelijke dienstverlening, met name de kinderopvang en het onderwijs. Het gaat kortom ook om sociale rechtvaardigheid, en in zoverre sluit dit rapport aan bij het onlangs door de raad uitgebrachte rapport De verzorgingsstaat herwogen. Flexibilisering van de arbeidsmarkt, in het bijzonder de versterking van de werkzekerheid en de bijbehorende inspanningen, behoeven en kennen ook een eigen rechtvaardiging.

In paragraaf 1.2 komen onder de noemer 'uitgangspunten voor afweging' doelmatigheid en rechtvaardigheid nader aan de orde.

Bij de keuze voor een nieuwe benadering is intussen niet alleen een theoretische onderbouwing van belang. Het functioneren van de arbeidsmarkt vindt plaats binnen kaders of instituties die gezamenlijk datgene vormen wat we verstaan onder 'arbeidsmarkt'. Zulke instituties zijn geschreven en ongeschreven regels, gewoonten en afspraken die een zodanige tijdsduur hebben dat zij als gevestigd kunnen worden beschouwd. Zij maken dat bedrijven niet volledig de vrije hand hebben bij het doorvoeren van veranderingen in de inzet van het personeel. Sommige vormen van flexibiliteit worden institutioneel aan banden gelegd. Voor een deel is dat het geval door wet- en regelgeving (Arbeidstijdenwet, Arbeidsomstandighedenwet) en voor een deel worden zaken ook in overleg met de bonden vastgelegd in collectieve arbeidsovereenkomsten. Ook personeelsvertegenwoordigingen kunnen invloed hebben op de (interne) flexibiliteit. Het is duidelijk dat het geheel van de instituties verondersteld wordt de verschillende belangen die bij de arbeidsmarkt in het geding zijn evenwichtig tot hun recht te laten komen. Omstandigheden kunnen met zich meebrengen dat ze per saldo negatief uitwerken, en dan zal naar een evenwicht gezocht moeten worden. Het is het zoeken van zo'n nieuw, toekomstbestendig evenwicht waaraan de raad in dit rapport een bijdrage wil leveren. Dat de combinatie van flexibilisering en werkzekerheid een evenwichtige oplossing kan vormen, wordt in paragraaf 1.3.3 onderstreept, en geconcretiseerd in de aanbevelingen in het slothoofdstuk.

\subsection{UITGANGSPUNTEN VOOR EEN AFWEGING}

Een centrale vraag in dit rapport is: hoe ziet de arbeidsmarkt eruit die adequaat is toegerust op de nieuwe uitdagingen van de internationale economie en de postindustriële samenleving? Discussies over flexibiliteit en zekerheid zijn sterk normatief gedreven. Verschillende belangen staan op het spel. De normatieve afweging tussen flexibiliteit en zekerheid heeft zowel een doelmatigheids- als een rechtvaardigheidscomponent. Hieronder presenteren we de essentiële elementen van beide onderdelen. Het afwegingskader is bedoeld om richting te geven aan de institutionele keuzen die in het slothoofdstuk gepresenteerd worden. Het gaat erom dat deze keuzen leiden tot ontwikkelingen die niet alleen doelmatig zijn, maar ook als rechtvaardig kunnen worden ervaren. Het gaat er bij de institutionele keuzen ook om dat de mogelijkheden en de verantwoordelijkheden voor de verschillende partijen met elkaar in evenwicht worden gebracht. 


\subsubsection{DOELMATIGHEIDSELEMENTEN}

\section{Optimale allocatie en productiviteitsgroei}

Mobiliteit op de arbeidsmarkt wordt in de eerste plaats bepaald door de zoektocht van aan de ene kant de werknemer naar de baan die het beste bij hem past en aan de andere kant van de werkgever naar de werknemer die voor zijn bedrijf het best op zijn plaats en het meest productief is. Zowel banen als werknemers zijn heterogeen en de variatie in kenmerken en individuele productiviteit is groot. Het is van tevoren niet bekend hoe een combinatie ('match') van een bepaalde werknemer en een baan zal uitpakken. Een baan is een ervaringsgoed. Men weet pas of een baan past als men er werkt. De onvermijdelijke heterogeniteit van mensen en banen en de informatieproblemen die daarmee gepaard gaan, leiden ertoe dat er altijd mensen (werkend en werkloos) op zoek zijn naar een baan en dat er altijd werkgevers met vacatures op zoek zijn naar werknemers. Ook als een werknemer een baan heeft gevonden, kan achteraf blijken dat deze niet bij hem past. Dat leidt dan tot een zoektocht naar een andere baan bij een andere werkgever (externe mobiliteit) of eventueel een verandering van functie bij dezelfde werkgever (interne mobiliteit). Een belangrijk deel van de arbeidsmobiliteit wordt veroorzaakt door deze niet te vermijden informatieproblemen.

De theoretische verwachting is dat dit zoekgedrag in een proces van succes en falen uiteindelijk leidt tot een optimale allocatie van werknemers over banen. Optimale allocatie betekent dat de werknemer gekoppeld (gematcht) wordt met de baan waar hij of zij op dat moment het meest productief is. In die zin levert arbeidsmobiliteit een belangrijke bijdrage aan de groei van de arbeidsproductiviteit. Hoe meer flexibiliteit de arbeidsmarktinstituties in zich bergen, hoe groter de mobiliteit kan zijn. Een optimale match in de zin van een meest productieve match, is meestal (niet altijd) een baan op het niveau dat het best bij deze werknemer past en daarmee leidt tot grotere baantevredenheid dan andere banen. Een optimale allocatie, het realiseren van matches met de juiste man/vrouw op de juiste plaats is dus niet alleen voor wat betreft de productiviteit van groot belang voor de economie, maar leidt ook tot grotere baantevredenheid en in die zin tot hoger welzijn.

\section{Participatie}

Het belang dat aan het niveau van de arbeidsparticipatie wordt gehecht, vormt een reden om de ontwikkeling van de arbeidsproductiviteit als gevolg van flexibiliteit niet te relateren aan de beroepsbevolking maar aan de potentiële beroepsbevolking. Als de arbeidsproductiviteit van de beroepsbevolking stijgt doordat minder productieve werknemers die eigenlijk nog kunnen werken, uit het arbeidsproces worden gestoten, dan beoordelen we die arbeidsproductiviteitstijging niet zonder meer als positief. Flexibiliteit zou niet ten koste moeten gaan van de arbeidsdeelname van de potentiële beroepsbevolking. Het maatschappelijke belang van arbeidsparticipatie vormt een reden om niet tegen elke prijs een hogere productiviteit na te streven. Bij deze overweging is ook het inzicht belangrijk dat de productiviteit door hogere participatie op korte termijn eenmalig kan dalen, maar op langere termijn het groeipotentieel veeleer zal bevorderen. 
Nog een reden om niet tegen elke prijs een hogere flexibiliteit na te streven is dat bedrijven er voordeel bij kunnen hebben om werknemers gedurende een bepaalde periode aan zich te binden. Werknemers en werkgevers investeren in elkaar en komen zo tot een hogere productie. Er zijn bijvoorbeeld altijd inwerkperioden nodig. Dergelijke investeringen moeten echter terugverdiend worden en daar is een zekere verblijfsduur in een baan voor nodig. Na verloop van tijd kan de meerwaarde van een match tussen een baan en een werknemer weer afnemen. Zoals later uit deze studie blijkt zijn lange baanduren nog steeds aan de orde van de dag.

Het instromen van geschikte werknemers, het vasthouden van deze werknemers zolang zij zich productief maken en het afvloeien van minder productieve werknemers, zijn alle van belang voor de arbeidsproductiviteit (en daarmee ook voor de winstgevendheid) van bedrijven. Flexibiliteit kan de arbeidsproductiviteit van de beroepsbevolking als geheel ten goede komen. Als banen verdwijnen is het in het belang van de economie dat de vrijgekomen arbeid elders emplooi krijgt. Of dit vervolgens voor individuele werknemers ook altijd gunstig is, is evenwel de vraag. Dit hangt immers af van het inkomen dat vertrekkende werknemers in een vervolgbaan gaan ontvangen. Dit kan hoger of lager liggen dan voorheen, samenhangend met hun productiviteit in hun oude en nieuwe baan. Vooral voor personen die aan het einde van hun loopbaan de werkzame beroepsbevolking uitstromen, kan dit een probleem zijn.

Degenen van wie de baan verdwijnt, gaan er meestal in inkomen op achteruit. Andere werknemers die vrijwillig van baan wisselen of op nieuw geschapen banen terechtkomen gaan er vaak op vooruit. Er zijn als gevolg van de teloorgang en de schepping van banen winnaars en verliezers. Structureel is het saldo van deze maatschappelijke herverdeling van welvaart altijd positief. Terugkijkend zien we dat processen van baancreatie en destructie op de lange termijn (los van conjuncturele schommelingen) leiden tot hogere economische groei, hogere productiviteit, en meer inkomen en vrije tijd per hoofd van de bevolking. Weliswaar is de winst van de winnaars groot genoeg om het verlies van de verliezers te compenseren, maar ook vanwege het gevaar van uitkeringspassiviteit is de raad van mening dat het belangrijker is dat werknemers die in een verliespositie dreigen terecht te komen, op korte termijn weer werk vinden. Het gaat erom dat er wordt geïnvesteerd in werkzekerheid.

\subsubsection{RECHTVAARDIGHEIDSELEMENTEN}

\section{Capabilities}

Arbeidsmarktbeleid kan niet zonder normatieve fundering. Iedere revisie van de institutionele inrichting van de arbeidsmarkt moet als normatief rechtvaardig kunnen worden beschouwd. In dit rapport sluit de raad aan bij Sen (1999), maar is ook aan de theorieën van Rawls (1971) en Dworkin (2000) aandacht geschonken. Bij Sen staat het optimaliseren van de kansen op ontwikkeling centraal. De meest elementaire rechtvaardigheidstheorie van de naoorlogse verzorgingsstaat 
en de gereguleerde arbeidsmarkt is die van Rawls (1971): Verandering in de verdeling van welvaart als gevolg van institutionele aanpassing is gerechtvaardigd, zolang op voorhand (van achter een sluier van onwetendheid over hoe de zaken uiteindelijk uitpakken) de verwachting is dat de positie van de groep die economisch het meest achtergesteld is, zal verbeteren. Volgens Dworkin is een bezwaar van Rawls' opvatting van sociale rechtvaardigheid dat deze weinig rekening houdt met de individuele verantwoordelijkheid. Deze kan verschillen als de verandering in de welvaart het gevolg is van wijzigingen in de externe omstandigheden of van individuele keuzes. Levenslopen en loopbanen staan bloot aan invloeden van buiten. Er kan echter ook richting aan de levensloop gegeven worden door werknemers zelf. Het is een breed geaccepteerd principe om verantwoordelijkheid te dragen voor individuele keuzes en dus ook voor keuzes betreffende de levensloop (Dworkin 20oo). De nadruk in de theorie van Rawls is erop gelegd dat de meest achtergestelde groepen ter compensatie elementaire aanspraken moeten worden toegekend. Als zodanig is Rawls' theorie gebruikt als rechtvaardiging voor de verzorgingstaat van de tweede helft van de twintigste eeuw die vooral gericht was op inkomenscompensatie via de sociale zekerheid. Materiële compensatie is weliswaar inkomenspolitiek gezien een adequaat beleid, maar vormt géén toereikende uitgangssituatie voor een eerlijke en efficiënte verdeling van loopbaankansen. In plaats van te focussen op gelijke welvaart, kan beter op gelijke kansen voor het actief verwerven van individuele welvaart geconcentreerd worden. Werkzekerheid kan bij uitstek gezien worden als een voorziening voor gelijke kansen op de arbeidsmarkt.

In de opvatting van Sen (1999) spelen vrijheid van handelen en de toerusting met middelen (capabilities) een vooraanstaande rol in het optimaliseren van kansen. Deze capabilities zijn meer dan alleen materiële middelen. Het gaat om de ontwikkeling van persoonlijke vermogens en mogelijkheden en omvat bijvoorbeeld de mogelijkheid om zorg- en ouderschapswerkzaamheden op zich te nemen. Sen wijst erop dat de toerusting ten behoeve van het ideaal van kansengelijkheid altijd plaats- en tijdgebonden is. Ook individuen verschillen in de mate waarin zij profijt kunnen trekken van hun toerusting. Sen ziet de noodzaak van een verschuiving van financiële compensatie naar compensatie via ondersteuning in de sfeer van voorzieningen. Met deze voorzieningen komt het verwerven van een arbeidsbetrekking binnen bereik. Deze betrekking is dan niet langer een kwestie van bittere noodzaak, maar dient ook het doel van maatschappelijke participatie en zelfontplooiing. Ook vestigt Sen de aandacht op de noodzaak van maatwerk; om mensen van buiten de arbeidsmarkt naar binnen te halen is een soms tot op individueel niveau gedifferentieerd beleid nodig. In termen van arbeidsmarktinstituties komt Sens pleidooi neer op minder financiële herverdelingsmechanismen en meer activerende, mobiliserende en participatiebevorderende instrumenten. Daarmee dragen de opvattingen van Sen ook bij aan het verhogen van de dynamiek op de arbeidsmarkt. Wat doorslaggevend is voor de dynamische postindustriële economie van de eenentwintigste eeuw, is de ex ante bekwaamheid van individuen om de middelen die hen ter beschikking staan om te zetten in de toestanden die ze zelf nastreven, dat wil zeggen een flexibele voorziening 
van middelen die best behoorlijk ongelijk verdeeld kan zijn, maar die alle individuen in staat stelt om de plannen te realiseren die ze met hun eigen leven hebben.

Sens opvattingen zijn niet alleen van belang voor degenen die buiten het arbeidsproces staan. Ook voor degene die al een baan hebben is het kunnen beschikken over steeds weer actuele capabilities van belang. Onzekerheid over de bestendigheid van een baan die men heeft, raakt een fundamentele waarde. Van alle omstandigheden die bepalend zijn voor het persoonlijk welbevinden, waartoe natuurlijk ook gezondheid, vrijheid en sociale contacten deel uitmaken, nemen financiële stabiliteit en het rustige bezit van een baan, belangrijke plaatsen in. Qua rangorde volgen ze onmiddellijk na de gezinssituatie, en ze scoren hoger dan de andere genoemde waarden (Layard 2005: 63). Werkloosheid wordt als nog bedreigender gezien dan financiële onzekerheid, en, verrassend genoeg, als schadelijker dan een situatie waarin men niet meer tot de werkzame bevolking wordt gerekend (ibid. 67).

\section{De openheid van de structuur van arbeidsmarktkansen}

In veel landen in de Europese Unie is sprake van een zekere overbescherming van de bepaalde groepen werknemers, de zogeheten insiders, met vaste aanstellingen en lange baanduren, naast minder ontwikkelde (of geheel ontbrekende) bescherming voor de zogeheten outsiders die werken in de meer kwetsbare sectoren in de marge van de arbeidsmarkt. Sommige groepen in de samenleving moeten voortdurend van baan wisselen en anderen zijn van onvrijwillige baanwisseling gevrijwaard. Werknemers met een vast arbeidscontract genieten een voorsprong op werknemers met een tijdelijk arbeidscontract: die laatsten wisselen vaker gedwongen - van baan. Van een onrechtvaardige verdeling zou sprake zijn als door de regelgeving de last van de mobiliteit stelselmatig bij bepaalde groepen komt te liggen. Werkzekerheid relativeert het belang van die ongelijkheid en betekent een verschuiving in van een statische notie van gelijkheid, waarin materiële bronnen (inkomen) en compensatiemiddelen centraal staan, naar een meer dynamische notie, gebaseerd op capaciteiten, kansen en empowerment (Esping Andersen 2002). Het is niet onrechtvaardig wanneer specifieke groepen voor een beperkte periode op tijdelijke contracten zijn aangewezen. Integendeel, het is in het bijzonder aanvaardbaar dat jongeren aan het begin van hun loopbaan zijn aangewezen op tijdelijke contracten als zij daardoor ervaring opdoen en de arbeidsmarkt verkennen op zoek naar een baan die bij hen past.

Concreet betekent de vertaling van die normatieve keuzen dat men zich moet richten op de effectiviteit en billijkheid waarmee middelen voor het verwerven van capabilities worden aangeboden. Deze middelen betreffen mogelijkheden om arbeidskwalificaties te verbeteren, inclusief mogelijkheden om op de arbeidsmarkt te participeren: dit kan onder meer door middel van kwaliteitsonderwijs, gezondheidszorg en sociale voorzieningen. Bij economische tegenslag gaat het dan niet meer om schadeloosstelling, maar om het aanreiken van middelen om de schade zelf te herstellen. Samengevat moeten de arbeidsmarktinstituties van de toekomst meer oog hebben voor het normatieve kader van dynamische gelijk- 
heid, de meeste aandacht schenken aan de toerusting van capabilities, zodat men meer open kan staan voor de prikkelende werking van differentiatie en flexibiliteit, en alert zijn op de vele uitzonderingen op de 'openheid' van de arbeidsmarktkansenstructuur.

Werkzekerheid impliceert dus een andere vorm van gelijkheid, niet gericht op inkomenscompensatie maar op empowerment.

Langs deze lijnen wordt in dit rapport voorgesteld om nieuwe vormen van zekerheid te ontwikkelen, die niet langer worden gezien als iets wat wordt gegeven als bescherming tegen verandering, maar als de fundering van een nieuwe vrijheid om te handelen in een snel veranderende economie en samenleving. Werkzekerheid kan dan als een actieve zekerheid worden beschouwd, die hand in hand gaat met de initiatieven van werknemers, werkgevers en overheid om de risico's te dragen van meer flexibele arbeidsrelaties.

\subsection{DE TRANSITIONELE ARBEIDSMARKT EN WERKZEKERHEID}

De drie centrale invalshoeken van dit rapport, bewegingen van baan naar baan, van functie naar functie en van buiten naar binnen, zijn onderdeel van een breder stromenmodel van de arbeidsmarkt. Arbeidsmarktstromen kunnen op een aantal manieren worden beschreven. Een benadering die recentelijk veel aandacht heeft gekregen zowel in wetenschapskringen als in kringen van beleidsmakers is die van de transitionele arbeidsmarkt.

\subsubsection{DRIE CENTRALE STROMEN}

De benadering van de transitionele arbeidsmarkt legt er de nadruk op dat loopbanen steeds minder via de geijkte patronen verlopen (Schmid 1995). Er vinden dus vaker transities plaats tussen verschillende arbeidsmarktstatussen. De transitionele arbeidsmarkttheorie concentreert zich op de beheersing van de risico's van deze arbeidsmarkttransities.

In de benadering van de transitionele arbeidsmarkt worden vijf toestanden of statussen onderscheiden waarin mensen zich op enig moment kunnen bevinden: huishouden (zorg), scholing, werkloosheid, pensionering en arbeid. Die toestanden zijn in figuur 1.1 weergegeven. Mensen kunnen van de ene naar de andere toestand overstappen. De relevante stromen zijn in figuur 1.1 genummerd van I tot en met V. Een stroom is de verzameling van alle mensen die in een bepaalde periode dezelfde transitie maken. Stroom I zijn mensen die binnen de betaalde arbeid een overgang maken (van de ene baan naar de andere, van arbeid in loondienst naar zelfstandige arbeid of omgekeerd). Stroom II zijn werknemers die werkloos (werkzoekend) worden of blijvend in de inactiviteit terechtkomen (volledig arbeidsongeschikt) dan wel werklozen en inactieven die betaalde arbeid vinden. Stroom III is tussen school en arbeid, stroom IV tussen huishouden en arbeid en stroom $\mathrm{V}$ gaat van arbeid naar pensioen. 
Hoe passen de drie centrale stromen van dit rapport in het transitionele arbeidsmarktmodel? De overgang van baan naar baan speelt op de externe arbeidsmarkt, in de figuur aangeduid met I. De overgang van functie naar functie speelt op de interne arbeidsmarkt binnen bedrijven en dus eveneens in het blok aangeduid met I. De mobiliteit van inactiviteit naar activiteit heeft in eerste instantie te maken met de stromen tussen de arbeidsmarkt en de werkloosheid (blok II), maar kan ook ruimer gezien worden. De problematiek van flexibilisering raakt ook aan de combinatie van zorg en arbeid, aan de verbinding tussen scholing en arbeid en aan de pensionering. In de figuur zijn dat de stromen horend bij III tot en met V. Voor het overgrote deel is de beleidsproblematiek die samenhangt met de zorg, scholing, pensioen en arbeid in het recente rapport over de verzorgingsstaat aan bod gekomen en behandeld. In dit rapport concentreren we ons alleen op deze transities, voor zover ze betrekking hebben op de flexibiliteit op de arbeidsmarkt.

\section{Figuur 1.1 Stromen op de transitionele arbeidsmarkt}

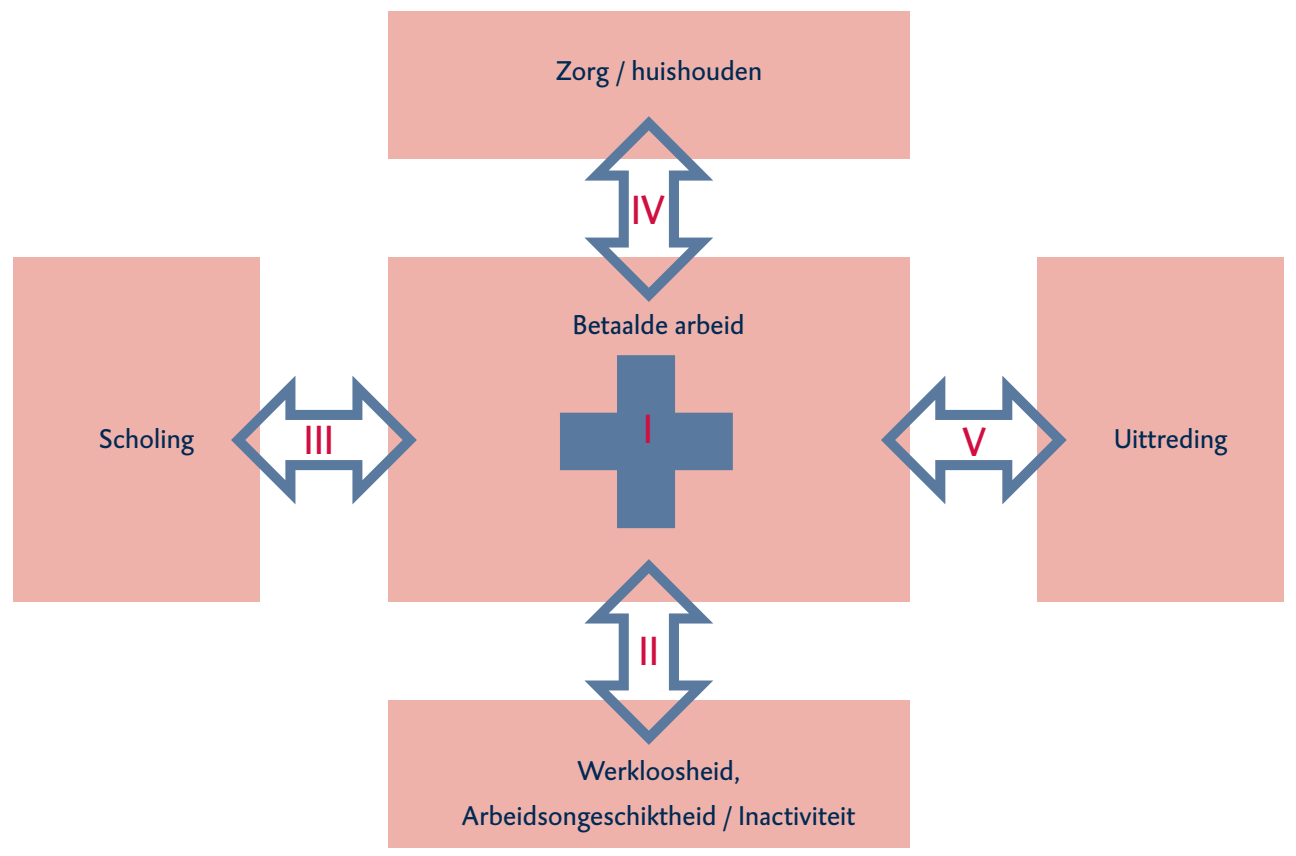

Bron: Wilthagen (2003)

In sommige studies wordt onderscheid gemaakt tussen numerieke flexibiliteit of flexibiliteit in de volumina en functionele flexibiliteit of veranderingen in de inhoud van het werk. Bij numerieke flexibiliteit kan worden gedacht aan het aantal werknemers dat van baan verandert of aan een verandering in het aantal uren dat werknemers werken (bijv. korter werken in slechte tijden of overuren in goede tijden). Bij functionele flexibiliteit kan gedacht worden aan een verandering in de aard van de werkzaamheden of in de inhoud van de functie van een werknemer. Naast deze kwantitatieve en kwalitatieve aspecten van flexibiliteit is 
er ook loon- of beloningsflexibiliteit. Loonflexibiliteit is een reactie op overschotten en tekorten op de arbeidsmarkt. Maar ook variatie in de wijze van beloning van werknemers (bijv. introductie van elementen van prestatieloon in een regime van vaste lonen) is een vorm van flexibiliteit. Dit rapport wordt heel specifiek op de drie eerdergenoemde centrale overgangen gefocust. De overgangen hebben vooral een kwantitatieve dimensie. Maar ook de andere kwalitatieve vormen van flexibiliteit en de beloningsflexibiliteit komen hier ter sprake. We streven ernaar om ter plekke duidelijk te definiëren over welke vormen van flexibiliteit we het hebben. Gerelateerd aan flexibiliteit is mobiliteit. Mobiliteit heeft specifiek betrekking op stromen, van functie naar functie, van baan naar baan en van buiten de arbeidsmarkt naar binnen vice versa. De mobiliteit van werknemers kan om verschillende redenen beperkt zijn, bijvoorbeeld doordat men deel uitmaakt van een huishouden waar andere leden ook bindingen mee hebben.

\subsubsection{RISICOMANAGEMENT}

Er zijn redenen waarom nu meer dan voorheen moet worden nagedacht over flexibiliteit en zekerheid. Er vinden op verschillende niveaus veranderingen plaats die van invloed zijn op baan- en functiemobiliteit. Een aantal ontwikkelingen heeft een internationaal karakter of een internationale herkomst. In het volgende hoofdstuk wordt een aantal van deze veranderingen uitgewerkt. Hierbij worden vijf categorieën onderscheiden: economische, technologische en demografische veranderingen, ontwikkelingen op het terrein van het human resource management en Europese veranderingen. Naast deze veranderingen met een sterk extern karakter zijn er voorts de risico's die vooral maatschappelijk en sociaal van aard zijn. Op de arbeidsmarkt is een aantal risico's helder te onderscheiden: (a) de risico's van sociale uitsluiting als gevolg van gebreken aan opleiding en training; (b) de risico's van onzekerheid als gevolg van het voortdurend aangewezen zijn op tijdelijk werk; (c) de risico's van gecomprimeerde arbeidscarrières vanwege de combinatie van arbeid en zorg, en (d) de groeiende risico's van langdurige werkloosheid of gedwongen inactiviteit als gevolg van de erosie van de baan voor het leven.

Deze externe en sociale veranderingen impliceren een veelheid aan veranderingen op de arbeidsmarkt en overgangen naar nieuwe arrangementen. De 'transitionele arbeidsmarkttheorie' houdt zich ook bezig met deze verschillende vormen van overgangen, en behelst een benadering van deze transities vanuit het perspectief van het risicomanagement (Schmid 2005). In plaats van zich uitsluitend te concentreren op de rechtvaardigheid van de situatie die ontstaat na het doormaken van arbeidsmarkttransities, moet volgens deze theorie ook aandacht geschonken worden aan de mate waarin personen zijn voorbereid op de genoemde risico's.

Het anticiperen op transitierisico's kent vele gedaanten. Om de combinatie van arbeid en zorg mogelijk te maken is flexibiliteit met betrekking tot de arbeidsduur noodzakelijk en zijn voorzieningen rond de opvang van kinderen gewenst. De 
beperkingen op de autonome keuzeruimte verdienen om te worden tegemoetgekomen. Om door te groeien op interne arbeidsmarkten en door te stromen op externe arbeidsmarkten of om over te gaan tot zelfstandig ondernemerschap, zijn niet aflatende investeringen in de inzetbaarheid van werknemers nodig.

De uitbreiding van het begrip werkzekerheid in de richting van een institutioneel verankerde employability vraagt om een actievere rol van de sociale partners. Met de ontwikkeling van een betrouwbare set van met elkaar verbonden instituties kan irrationele risicoaversie die leidt tot suboptimale arbeidscarrières worden voorkomen. Afhankelijk van het gegeven of transitierisico's zijn veroorzaakt door een individuele keuze of door externe omstandigheden, en of de consequenties van de risico's individueel gedragen kunnen worden of de mogelijkheden van het individu te boven gaan, kunnen risico's worden gemitigeerd op individueel, privaat collectief (cao's) en publiek niveau. Het gaat erom de verantwoordelijkheden zo te verdelen dat een effectieve prikkelstructuur ontstaat. De betrokken partijen moeten op een doelmatige wijze op hun eigen verantwoordelijkheid worden aangesproken.

\subsubsection{DRIE ZEKERHEDEN}

Voortbouwend op het rapport De verzorgingsstaat herwogen, en in navolging van Sens capabilities-benadering, wordt in dit rapport voorgesteld om nieuwe institutionele vormen van flexibiliteit en zekerheid te ontwikkelen als de fundering van een nieuwe vrijheid om te handelen. Werkzekerheid wordt in dit rapport gezien als een dergelijke vrijheid van handelen. De institutionele voorwaarden waaraan voldaan moet zijn om werkzekerheid te scheppen zijn geconcentreerd rond de investeringen die een werknemer tijdens zijn loopbaan in zichzelf moet doen om een aantrekkelijke partij op een veranderende arbeidsmarkt te blijven. Het mogelijk maken om deze investeringen te doen, vergen, in termen van tijd, geld en begeleiding, ook institutionele aanpassingen die de werknemer, de werkgever en de overheid raken.

Zekerheid en flexibiliteit kunnen in elkaars verlengde liggen. Beide hebben te maken met arbeidsmarktinstituties. Sommige arbeidsmarktinstituties kunnen flexibiliteit in de weg staan. Weer andere voorzien daarentegen in stevig verankerde randvoorwaarden die individuele burgers stimuleren om risico's te nemen, bedrijven aanmoedigen om te investeren in fysieke productiecapaciteiten en in de opschaling van menselijk kapitaal, en beleidsmakers stimuleren zich te concentreren op de modernisering van de arbeidsverhoudingen, arbeids- en verlofregulering, de sociale zekerheid en de maatschappelijke dienstverlening.

Zekerheid wordt geboden door de 'verzekering' dat de nadelige gevolgen van flexibiliteit kunnen worden opgevangen. Zekerheid gerelateerd aan arbeidsflexibiliteit werd tot voor kort gezocht in 'baanzekerheid' en 'inkomenszekerheid'. Baanzekerheid wordt vormgegeven door maatschappelijke instituties (zoals de interne arbeidsmarkt en de ontslagbescherming) waardoor insiders erop mochten 
vertrouwen dat de baan die ze hadden voor zover mogelijk voor het leven kon worden bezet. De vakbeweging heeft zich historisch sterk gemaakt voor baanzekerheid. Inkomenszekerheid kreeg vorm door sociale zekerheidsregelingen die bij het wegvallen van een baan zorgden voor inkomen. De veranderingen die hierboven zijn geschetst maken dat baanzekerheid geleidelijk op de tocht komt te staan. Ervaringen met de sociale regelingen voor inkomenszekerheid hebben ons geleerd dat deze regelingen vaak leiden tot een langdurige uitkeringsafhankelijkheid. In dit rapport staat het begrip werkzekerheid centraal. Dit houdt in dat als een bestaande arbeidsrelatie verbroken wordt, er dankzij de voortdurende aandacht voor investering in en op peil houden van capabilities de voorwaarden aanwezig zijn waaronder de werknemer het vertrouwen kan hebben weer (snel) werk te vinden bij een andere werkgever en dus niet (lang) in de werkloosheid terecht te komen. De analyses van dit rapport zijn erop gericht om in het beleidshoofdstuk aan het eind te kunnen definiëren wat het betekent om werkzekerheid institutioneel vorm te geven in een arbeidsmarkt met intense baanwisseling en functiewisseling en hoe we niet alleen werkzekerheid kunnen bieden aan de insiders maar ook aan de outsiders, de mensen die nu nog buiten de reguliere banen vallen. Flexibilisering leidt in deze zin niet alleen tot doelmatigheid maar ook tot rechtvaardigheid.

\subsection{PROBLEEMSTELLING VAN HET RAPPORT}

De centrale focus in het arbeidsmarktbeleid van de afgelopen regeerperioden was het verhogen van de arbeidsparticipatie en activering van mensen met een uitkering. De raad heeft hier onder andere met de rapporten Een werkend perspectief (1990), Tweedeling in perspectief (1996) en Doorgroei van arbeidsparticipatie (2000) aan bijgedragen. Bevolkingsgroepen die nog buiten de arbeidsmarkt stonden werden tot participatie gestimuleerd (denk aan de verhoging van de participatie van vrouwen in de jaren negentig), vervroegd uittreden door vijftigplussers werd niet langer begunstigd en reïntegratie van mensen zonder werk werd gestimuleerd. Deze participatieverhoging is, met variatie, redelijk succesvol geweest. De participatiedoelstelling is nog altijd van kracht. Er is nog ruimte voor hogere participatie (van bijvoorbeeld mensen in de bijstand, oudere werknemers, vrouwen, werknemers met kleine banen). Het is met het oog op de toekomst echter noodzakelijk om aan beleid te denken dat verder gaat dan participatie. Er is bij hoge participatie behoefte aan een optimale inzet van het arbeidspotentieel. Daarbij gaat het om een kwalitatieve verbetering van de manier waarop de talenten van werknemers op de arbeidsmarkt worden aangewend. Hoe en waar mensen op de arbeidsmarkt worden ingezet valt onder de brede term flexibiliteit van arbeid. Arbeidsflexibiliteit is overigens zelf ook weer gunstig voor meer participatie. Een flexibele en betere aansluiting van het aanbod op de vraag naar arbeid creëert mogelijkheden voor meer vraag naar arbeid en dus meer arbeidsplaatsen. Het blijkt dat grote flexibiliteit op de arbeidsmarkt en hoge arbeidsparticipatie vaak samengaan (Bradley en Stephens 20o6). Op dit punt is er weinig verschil tussen de liberale markteconomie van de Verenigde Staten en die van de Zweedse verzorgingsstaat. 
Werkzekerheid vereist dat de samenleving investeert in preventie en inzetbaarheid en in een aanpassing van haar instituties. De beleidsimplicaties voor nieuwe institutionele vormen van flexibiliteit en zekerheid betreffen een breed palet van arbeidsmarktinstituties, waaronder arbeidsmarktregulering, het minimumloon, de cao, de sociale verzekeringen, investeren en behoud van capabilities, verlofregelingen en maatschappelijke dienstverlening. Daarbij is de samenhang tussen institutionele arrangementen van groot belang. Bij de realisatie van 'werkzekerheid' zijn alle instituties van belang die betrokken zijn bij de overgang van de ene baan naar de andere. De realisatie van werkzekerheid betekent onder meer dat al deze instituties in hun onderling verband moeten worden bekeken en dat het geen zin heeft om een daarvan, namelijk het regime van ontslagbescherming, daar apart uit te lichten. In termen van verantwoordelijkheid veronderstelt werkzekerheid de betrokkenheid van alle partijen die employability kunnen bevorderen. Zowel de werknemer, de werkgever als de overheid is belangrijk. Overleg tussen werkgevers en werknemers op bedrijfsniveau (via vakbonden en in de ondernemingsraden) heeft invloed op de mogelijkheden van flexibilisering op het niveau van het bedrijf. Afspraken over scholing in cao's kunnen interne en externe flexibiliteit bevorderen. Toegankelijke en kwalitatief hoogstaande publieke kinderopvang kan de inzet en flexibiliteit van zorgwerkers bevorderen. Ten slotte moet werkzekerheid voor de verschillende arbeidsmarktsegmenten en -groepen adequaat zijn, hetgeen ruimte veronderstelt voor maatwerk en differentiatie.

De hierboven geschetste problematiek leidt tot de volgende vraagstelling voor het rapport: Hoe zijn de institutionele condities te creëren om, gegeven de veranderende omgeving nu en in de toekomst, voor verschillende groepen op de arbeidsmarkt werkzekerheid te scheppen en tegelijkertijd tegemoet te komen aan de behoefte aan flexibilisering met het oog op een zo groot mogelijke arbeidsparticipatie en een voortgaande groei van de arbeidsproductiviteit?

De beantwoording van deze vraag wordt in een aantal stappen voorbereid. Eerst wordt de arbeidsmarkt verkend op zijn flexibiliteit en worden daarin knelpunten gesignaleerd. Daarbij worden de drie invalshoeken van baan naar baan, van functie naar functie en van buiten naar binnen aangehouden. De raad heeft hiervoor gebruikmakend van het Sociaal Statistisch Bestand van het Centraal Bureau voor de Statistiek onderzoek verricht naar de mobiliteit op de Nederlandse arbeidsmarkt. Vervolgens wordt ingegaan op de arbeidsmarktinstituties die mede bepalend zijn voor de werking van de arbeidsmarkt. De opbouw van dit rapport is als volgt. In het tweede ('internationale') hoofdstuk worden de belangrijkste ontwikkelingen geschetst die tot grotere arbeidsmarktflexibiliteit dwingen; voorts worden er op basis van een internationale vergelijking van arbeidsmarktindicatoren de arbeidsmarktprestaties van Nederland beoordeeld. Het arbeidsmarktbeleid is een terrein waar het nationaal beleid doorslaggevend is. In het licht van de internationalisering van productmarkten en financiële markten neemt het ook in belang toe. In het derde hoofdstuk wordt de mobiliteit van baan naar baan op de arbeidsmarkt (externe flexibiliteit) besproken. Winnaars en 
verliezers worden in beeld gebracht en de relatie met stijging van de productiviteit wordt gelegd. In het vierde hoofdstuk wordt de mobiliteit van functie naar functie (interne flexibiliteit) aan de orde gesteld. In het vijfde hoofdstuk gaat het over de bewegingen van buiten naar binnen op de arbeidsmarkt en wordt de positie van een aantal specifieke groepen bezien. De relevante instituties van de arbeidsmarkt worden in het zesde hoofdstuk besproken. In het zevende en laatste hoofdstuk worden, bouwend op de bevindingen van de vorige hoofdstukken, enkele hoofdrichtingen aangeduid die de komende jaren kunnen leiden tot een vergroting van werkzekerheid, als noodzakelijke voorwaarde voor een aanvaardbare flexibilisering van de arbeidsmarkt. In dit laatste hoofdstuk worden daartoe aanbevelingen gedaan die zowel de externe als de interne flexibiliteit van werkende personen betreffen, als de inzet van personen die zich momenteel bevinden in de marge van de arbeidsmarkt. Daarbij worden aanbevelingen gedaan om de relevante arbeidsmarktinstituties beter op elkaar af te stemmen en daarbij een oriëntatie op werkzekerheid te verankeren in het arbeidsbestel. Een hoeksteen van het beleidsadvies is de toerusting van de partijen op de arbeidsmarkt om aan een grotere werkzekerheid daadwerkelijk gestalte te geven. 


\section{INTERNATIONALE ONTWIKKELINGEN EN VERGELIJKINGEN}

\subsection{INLEIDING}

In dit hoofdstuk komen allereerst een aantal internationale ontwikkelingen aan de orde die voor de arbeidsmarkt van belang zijn. Deze ontwikkelingen hebben of een internationale herkomst of een internationale verschijningsvorm. Het vervolg van dit hoofdstuk gaat over de prestaties van de Nederlandse arbeidsmarkt in vergelijking met die in andere EU-lidstaten. Een soepel werkende arbeidsmarkt draagt ertoe bij dat werknemers daar tewerkgesteld zijn waar zij het best renderen c.q. het meeste verdienen. Ook moet de arbeidsmarkt de wensen van werknemers accommoderen, zoals die welke voortvloeien uit het combineren van zorgtaken met arbeid, of die voortkomen uit de behoefte aan nieuwe kansen op de arbeidsmarkt (SCP 2004). Niet minder belangrijk is dat de arbeidsmarkt in staat is om werknemers die gedwongen zijn hun baan te verlaten voor het arbeidsproces te behouden, en degenen die willen toetreden tot de arbeidsmarkt ook daadwerkelijk op te nemen. Op deze essentiële functies zullen de prestaties van de Nederlandse arbeidsmarkt worden vergeleken met die van de lidstaten van de EU.

\subsection{EXTERNE ONTWIKKELINGEN}

\section{Economische ontwikkelingen}

De noodzaak van flexibilisering wordt de laatste tijd steeds nadrukkelijker verbonden met de door de globalisering aangewakkerde concurrentiedruk. Aziatische landen manifesteren zich nadrukkelijk op de wereldmarkt. Ook dichter bij huis neemt de concurrentie toe. De economie van de landen in Midden- en OostEuropa raakt steeds meer verweven met de economie van de landen in WestEuropa. Flexibilisering van productiestructuren brengt met zich mee dat delen van de productie uit West-Europa verplaatst worden naar landen waar kostenvoordelen zijn te behalen. Deze veranderingen hebben gemeen dat ze leiden tot een intensivering van de concurrentieverhoudingen op de afzetmarkten van bedrijven. Ook de modernisering van het concurrentietoezicht in Nederland en Europa vanaf de jaren negentig dwingt betere concurrentieverhouding af op nationale en Europese afzetmarkten. Reële loonstijgingen aan de onderkant van de arbeidsmarkt gaan minder hard dan in het verleden. Er zijn aanwijzingen dat de onderkant van het loongebouw steeds meer beïnvloed wordt door de internationale verschuivingen in de productie (Acemoglu 2002).

Hoe meer concurrentie, hoe meer bedrijven worden gedwongen tot een scherpere kostencalculatie, productiviteitsverbetering, innovatie, meer efficiëntie van de inzet van arbeid en daarmee ook meer arbeidsflexibiliteit Meer concurrentie betekent minder marktmacht voor bedrijven en minder 'vetrandjes' voor werknemers. Een bedrijf met marktmacht hoeft zijn arbeidsorganisatie niet snel aan te passen. Hogere kosten worden doorberekend in de afzetprijzen en worden afgewenteld op de rest van de samenleving. In een concurrerende omgeving moeten 
arbeidsorganisaties zich aanpassen aan de wensen van de afnemers en de bedreiging van de concurrenten. Ze kunnen ze zich geen 'vetrandjes' meer veroorloven. Deze externe druk wordt in de toekomst niet minder; integendeel. Niet alleen productmarkten maar ook kapitaalmarkten worden steeds meer mondiaal. Internationale fusies en overnames hebben invloed op de arbeidsorganisatie en de interne flexibiliteit van de betrokken bedrijven. Organisatorische verandering in de concurrerende sectoren wordt bovendien geleidelijk overgenomen door de beschermde sectoren.

\section{Technologische ontwikkelingen}

De invloed van ICT reikt ver. Het is een 'doorbraaktechnologie' die zich op alle plaatsen in de economie doet gelden (Castells 1996; СРB 2000). De computer en de communicatienetwerken zorgen voor meer transparantie. Het wordt makkelijker om prijzen te vergelijken. Tussenpersonen worden uitgeschakeld. De toepassing van ICT intensiveert daarom de werking van de markt: de onderlinge concurrentie verhevigt, toetreding tot bestaande markten en het aanboren van nieuwe markten worden vergemakkelijkt, traditionele schaalvoordelen verdwijnen, terwijl ze in netwerkbedrijven juist toenemen. De steeds verder doordringende introductie van ICT in de productie- en distributieprocessen heeft gevolgen voor de flexibiliteit van arbeid.

De invloed van ICTgeldt ook voor de logistiek. Het voordeel van ICT voor handel tussen bedrijven is goed te zien aan de pijlsnelle opbloei van de business to business e-commerce. ICT helpt om de voordeligste leverancier te vinden, contracten af te sluiten en minder voorraad aan te houden. ICT vergemakkelijkt de just in time productie door efficiëntere communicatie met de toeleveranciers. Volgens het Centraal Economisch Plan 2000 is dit merkbaar aan de veel lagere voorraadvorming bij bedrijven (СРВ 2000). Dit houdt in dat bedrijven minder dan vroeger productieschommelingen opvangen met voorraadaanpassingen. Blijven werken voor het aanvullen van voorraden in een laagconjunctuur komt minder voor. Productieschommelingen komen daardoor veel meer bij de werknemers terecht.

Er zijn natuurlijk meer innovaties dan alleen die gerelateerd zijn aan ontwikkelingen op het terrein van ICT. Product- en procesinnovatie worden voortdurend geïnitieerd. Bijvoorbeeld in 2004 betrof 4 procent van de omzet nieuwe producten. Bekend is ook dat de levenscyclus van nieuwe producten en diensten steeds korter wordt. De noodzaak van flexibilisering word t ook gekoppeld aan technologische ontwikkelingen in de productieprocessen, waardoor de vraag naar arbeid relatief meer verschuift in de richting van hoger geschoolde arbeid en minder in de richting van laaggeschoolde arbeid (Jacobs 2004). Deze verschuivingen veroorzaken spanning op de arbeidsmarkt die tot uiting komt in een grotere ongelijkheid in de beloningen tussen geschoolde en ongeschoolde arbeid en een relatieve verslechtering van de arbeidsmarktkansen voor minder geschoolde werkzoekenden. De vraag naar hoger opgeleiden vanuit de bedrijven groeit de laatste jaren sneller dan het aanbod. Dit geldt niet voor lager opgeleiden. Door deze relatieve verschuivingen in de vraag naar arbeid nemen de aansluitingsproblemen op de arbeidsmarkt toe. 


\section{Ontwikkelingen op het gebied van human resource management}

Veranderingen van de arbeidsorganisatie en de behoefte aan arbeidsflexibiliteit komt ook van binnen de bedrijven in de vorm van reorganisaties, innovaties, afsplitsing en andere operaties. In de jaren zeventig en ook nog in de jaren tachtig was de meeste bedrijvigheid in Europa geschoeid op concepten van centraal aangestuurde industriële massaproductie. Door nieuwe ontwikkelingen in de manier waarop bedrijven hun activiteiten organiseerden kwamen deze organisatieconcepten onder druk te staan. Gaandeweg zijn de mogelijkheden voor flexibele specialisering en gedifferentieerde kwaliteitsproductie opgepakt (Piore en Sabel 1984; Hall en Soskice 2001).

In het verlengde van de organisatorische vernieuwingen vindt ook een moderniseringsslag plaats op het gebied van human resource management. Een aantal trends vormt een uitdaging voor de te maken keuzen op HRM-gebied (Van der Heijden en Bochhah 2006). De transparantie van ondernemingen is door de digitalisering sterk toegenomen, zowel van binnen naar buiten (mass-customization) als van buiten naar binnen (customer control). Vaste patronen vervagen onder meer in relatie met telewerken en arbeidstijden en op het vlak van functie-inhouden. De pluriformiteit van werknemers heeft onder meer gevolgen op hun vertegenwoordiging door vakbonden en ondernemingsraden. Er is onzekerheid met betrekking tot de ontwikkeling van de sociale zekerheid. Er is een trend naar meer autonomie en verantwoording op allerlei gebied. In dat verband worden de resultaten van bedrijfsonderdelen vastgelegd en wordt intern op prestaties afgerekend. Het bewustzijn van de relatie tussen gezondheid en werk is sterk toegenomen. En ten slotte is ook meer nadruk komen te liggen op het eigen initiatief en de ondernemendheid van de werknemer.

Een uitdaging voor het human resource management in een tijd van krapte op de arbeidsmarkt is het binden van werknemers. Een voorwaarde voor binding is dat werknemers een zekere autonomie hebben om hun werk in overeenstemming met hun voorkeuren en omstandigheden vorm te geven. Een steeds belangrijker factor is ook dat werknemers zich in hun werk kunnen ontplooien. Het recht van werknemers om zich in hun werk te kunnen ontwikkelen is wellicht de belangrijkste secundaire arbeidsvoorwaarde van de toekomst.

\section{Demografische ontwikkelingen}

De vergrijzing van de beroepsbevolking heeft voor de werking van de arbeidsmarkt in de volgende decennia een aantal ingrijpende gevolgen. Het aandeel van de oudere werknemers in de personeelsopbouw van bedrijven en instellingen neemt toe, mede doordat de mogelijkheden voor vervroegde uittreding sterk zijn verschraald. Oudere werknemers $\left(45^{+}\right)$maken nu ongeveer 31 procent van het totale arbeidsaanbod uit. Het aandeel oudere werknemers stijgt tot meer dan 40 procent in 2020 en daalt dan in de volgende twee decennia weer enigszins, terwijl het babyboom-effect uit de arbeidsmarkt verdwijnt. In 2000 zijn ongeveer 2,3 miljoen werkenden tussen de 45 en de 74 jaar. In 2020 worden dat er 3 miljoen dan wel 3,7 miljoen (Centraal Planbureau 2004). 
Er zal onvermijdelijk meer aandacht uitgaan naar het personeelsbeleid voor de productieve inzet van deze werknemers. De instroom van jongeren en schoolverlaters op de arbeidsmarkt wordt over de jaren minder. Bedrijven en instellingen die in het verleden verjonging en verversing van hun personeelsbestand probleemloos hebben kunnen uitvoeren door het vervangen van uitstromende oudere werknemers door jongere werknemers kunnen dit in de toekomst in mindere mate.

Hier komt bij dat de inactiviteit onder ouderen aanzienlijk hoger is dan onder jongeren. Als de participatiecijfers van ouderen niet verder toenemen, daalt straks de omvang van de Nederlandse beroepsbevolking. En er is meer. Oudere werknemers zijn over het algemeen minder flexibel. Het zijn vaak de oudere werknemers die het veld moeten ruimen als het personeelsbestand van een bedrijf inkrimpt. Oudere werknemers $\left(45^{+}\right)$die hun baan kwijtraken hebben slechte arbeidsmarktkansen. Zonder verdere maatregelen zal de flexibiliteit van de arbeid door de vergrijzing worden aangetast. De arbeidsmarkt voor oudere werknemers functioneert op dit moment vrijwel niet. De arbeidsmarkt voor oudere werknemers vereist daarom bijzondere zorg voor de toekomst.

De arbeidsmarkt van de toekomst kent een grote variatie in de beroepsbevolking. Tweeverdiener- en anderhalfverdienerhuishoudens zullen nog meer dan nu het beeld bepalen van de arbeidsmarkt en het arbeidsmarktbeleid. Jongere generaties vrouwen die nu werken, blijven werken ook als ze ouder worden. Jonge vrouwen die nu uitstromen uit het onderwijs zullen meer nog dan hun moeders, hun hele actieve leven op de arbeidsmarkt participeren. De arbeidsmarktparticipatie van vrouwen gaat steeds meer op die van mannen lijken. Of dat tot een volledige gelijkschakeling van mannen en vrouwen zal leiden is niet gezegd.

In de toekomst zal de arbeidsmarkt ook kleurrijker worden. Door het verschil in vruchtbaarheid neemt het aandeel allochtonen in de Nederlandse bevolking en dus ook in de beroepsbevolking toe. De arbeidsparticipatie van allochtonen is in de afgelopen jaren flink gestegen. Velen verwachten in de volgende decennia een toestroom van immigranten uit de nieuwe lidstaten van de Europese Unie, uit Oost- en Centraal-Europese landen, Turkije en Noord-Afrika. Deze immigranten komen uit landen met een relatief jonge bevolking, worden aangetrokken door het te verwachten vraagoverschot op de Nederlandse en Europese arbeidsmarkt en door het verschil in per capita inkomen in hun eigen land ten opzichte van West-Europa.

De grotere heterogeniteit van de arbeidsmarkt betekent ook dat vanuit de aanbodkant andere behoeften worden geformuleerd betreffende de inzet van arbeid. De moeilijke combinatie van zorg en arbeid is daar een duidelijk voorbeeld van.

\section{Europese veranderingen: Stabiliteitspact en Lissabon}

Een laatste aanleiding om de noodzaak van debat over de flexibilisering van arbeid verder te benadrukken ligt in de monetaire eenwording. Hierdoor zijn de lidstaten van de Europese Unie hun monetaire beleid als beleidsinstrument en 
daarmee ook het aanpassingsmechanisme van de wisselkoersen kwijtgeraakt. Of dit voor Nederland nog een krachtig instrument was, valt overigens te betwijfelen. Verder is door de invoering van het Stabiliteits- en Groeipact eveneens het budgettaire beleid aan banden gelegd. Budgettaire druk heeft, sinds het begin van de jaren tachtig, weliswaar bijgedragen aan een cumulatie aan hervormingen en reorganisaties gericht op de afslanking van de bestaande structuren. Met het wegvallen van deze twee beleidsinstrumenten die voorheen veelvuldig werden ingezet om schokken op te vangen, is meer druk komen te staan op aanpassingen via de arbeidsmarkt.

De intensivering van economische internationalisering en de verregaande europeanisering van macro-economisch beleid (interne markt en EMU) hebben de grenzen verlegd waarbinnen binnenlandse coördinatie mogelijk is en stellen nieuwe eisen aan slagvaardig arbeidsmarktbeleid. Bovenstaande ontwikkelingen confronteren beleidsmakers met een netelig vraagstuk: hoe kan Europa's normatieve ambitie voor sociale rechtvaardigheid in lijn worden gebracht met het streven, geformuleerd tijdens de Raad van Lissabon in 2000, om in 2010 "de meest concurrerende en dynamische kenniseconomie van de wereld te worden met hogere en betere werkgelegenheid en meer sociale cohesie" (Europese Raad, 22 en 23 maart 200o)? Die doelstelling gaat nadrukkelijk gepaard met arbeidsflexibiliteit. Hierboven is een groot aantal (toekomstige) veranderingen de revue gepasseerd. Deze veranderingen maken dat baan- en functiewisselingen waarschijnlijk vaker zullen voorkomen. De samenleving moet meer dan ooit leren omgaan met flexibiliteit op de arbeidsmarkt en de activering van mensen die buiten de boot vallen.

Een optimale institutionele vormgeving van flexibiliteit op de arbeidsmarkt moet ertoe bijdragen dat de hierboven geschetste veranderingen leiden tot een betere re-allocatie van arbeid tussen bedrijven (van baan naar baan), tot een betere reallocatie van arbeid binnen bedrijven (van functie naar functie) en een hogere inschakeling van de beroepsbevolking op de arbeidsmarkt (van buiten naar binnen). Maatregelen die ertoe leiden dat bepaalde groepen die thans minder dan gemiddeld deelnemen aan de arbeidsmarkt (ouderen, vrouwen en laagopgeleiden), gemakkelijker hun weg (kunnen) vinden naar de arbeidsmarkt, zijn hierbij belangrijk. Omdat zekerheden ook op korte termijn grenzen kunnen stellen aan flexibiliteit, verdient het aanbeveling om werkzekerheid en flexibiliteit als complementaire begrippen te beschouwen en te zoeken naar een optimale institutionele combinatie.

\subsection{INTERNATIONALE VERGELIJKING}

Aan het functioneren van de arbeidsmarkten worden in de komende jaren hoge eisen gesteld, om het hoofd te kunnen bieden aan de vele economische veranderingen en het toenemende beslag op de verzorgingsstaat. Van de arbeidsmarkt wordt verwacht dat ze deze veranderingen op soepele wijze mogelijk maakt. Een soepel werkende arbeidsmarkt draagt ertoe bij dat werknemers daar tewerkgesteld zijn waar zij het best renderen c.q. het meeste verdienen. Ook moet de 
arbeidsmarkt de wensen van werknemers accommoderen, die vooral met het combineren van zorgtaken met arbeid te maken hebben, maar ook met de behoefte aan nieuwe kansen (SCP 2004). Niet minder belangrijk is dat de arbeidsmarkt in staat is om werknemers die gedwongen zijn hun baan te verlaten voor het arbeidsproces te behouden.

\section{Beoordeling van arbeidsmarkten}

Om het functioneren van arbeidsmarkten te beoordelen kan men verschillende benaderingen volgen. Een eerste mogelijkheid is het maken van een vergelijking met de prestaties uit het verleden. De recente prestaties van de Nederlandse arbeidsmarkt wijzen dan op een hoge mate van kwetsbaarheid. De werkgelegenheid, zowel in personen als in mensjaren, is in 2006 nog steeds lager dan in 2001. Ook slaagt de Nederlandse arbeidsmarkt er niet goed in om de uitkeringsafhankelijkheid te doen verminderen. Ondanks vele maatregelen gericht op activering, is de verhouding tussen uitkeringsontvangers en werkenden in 2006 even hoog als vijf jaar geleden. Een tweede mogelijkheid is het vergelijken van groepen en deelmarkten. Er blijken dan aanzienlijke verschillen te bestaan. Zo is de arbeidsdeelname van de laagst opgeleiden ongeveer de helft van die van de hoger opgeleiden. De participatie van vrouwen bedraagt driekwart van die van mannen. De participatie van de leeftijdscategorie van 60 jaren en ouder bedraagt nog niet eens een derde van de generatie jonger dan 55 jaren. Mensen met een uitkering blijken, zelfs in tijden van spanningen op de arbeidsmarkt, slechts in beperkte mate de overgang naar een betaalde baan te maken (СРВ 2000: 139). Een derde mogelijkheid is het functioneren te bezien in het licht van nieuwe ontwikkelingen. De externe ontwikkelingen kwamen hierboven al aan de orde. Daarnaast zijn er sociale ontwikkelingen. Het aanbod van werknemers is steeds beter opgeleid, maar heeft ook andere wensen op het gebied van loopbanen, vrije tijd en werktijden dan voor de traditionele mannelijke werknemer het geval was. De arbeidsmarkt vereist in de toekomst niet alleen voldoende flexibiliteit om de dynamiek te pareren waar demografische, economische en sociale ontwikkelingen om vragen, maar ook om te voorzien in de wensen en voorkeuren van een hoger opgeleid arbeidspotentieel. Een vierde mogelijkheid is de waardering van de verschillende aspecten van het functioneren ervan door de deelnemers. Evaluatieonderzoek is vaak gekoppeld aan instituties, waaronder wetgeving. In hoofdstuk 6 over instituties komen evaluerende onderzoeken ter sprake die ruimte voor verbetering aantonen.

\section{Internationale vergelijking}

Internationale vergelijking biedt een vijfde mogelijkheid om het functioneren van de arbeidsmarkt te beoordelen. Tekortkomingen van nationale arbeidsmarkten, zoals er zojuist enkele van de Nederlandse arbeidsmarkt werden aangestipt, kunnen hierdoor beter in perspectief worden geplaatst.

Er is een vrij lange traditie waarin arbeidsmarktprestaties in de eerste plaats worden verklaard door de mate van arbeidsmarktregulering en, ruimer, door de omvang van de verzorgingsstaat. De OECD verklaarde de hoge werkloosheid uit 
het midden van de jaren negentig uit "an inability ...to adapt rapidly and innovatively to a World of rapid structural change” (OECD 1994: I, vii). Omdat de eerste constatering in deze studie is dat de werkgelegenheidsgroei in de jaren tachtig in Noord-Amerika driemaal zo hoog is als in de landen van de EU (OECD 1994: I, 2), worden de verschillen tussen de sociaal-economische arrangementen in deze gebieden als belangrijke verklaringen beschouwd. Deze OECD Jobs Studies bevatten ook recepten om tot betere arbeidsmarktprestaties te komen, die, zoals reeds opgemerkt, sterk gefocust waren op de arbeidsmarktinstituties. Zou men de impact hiervan weten te vermijden dan zou het allengs beter gaan.

"Remove labour-market regulations, eliminate job-protection laws, reduce unemployment benefits, weaken unions, decentralize wage-setting, and presto! European unemployment would vanish. That, at least is the crude version of the conventional wisdom of the decade. In a more sophisticated form, this is the message of the OECD Jobs Study" (Freeman 1995).

Het eenzijdig en in isolatie bezien van afzonderlijke instituties is inmiddels achterhaald; instituties vertonen interdependenties. Een actief arbeidsmarktbeleid kan bijvoorbeeld nadelen van een genereus werkloosheidsregime of van een liberaal ontslagstelsel wegnemen. In het algemeen geldt dat een introductie van flexibiliteit die gepaard gaat met maatregelen die inkomens- en/of werkzekerheid bieden, de bezwaren van de onzekerheid die flexibiliteit teweegbrengt, kan wegnemen. Het gaat dan om een combinatie van pressie om deel te nemen aan reïntegratie-inspanningen teneinde de verleiding om te profiteren van hoge werkloosheidsuitkeringen te neutraliseren, en ondersteuning die moet leiden tot betere matches op de arbeidsmarkt dan werklozen op eigen kracht zouden kunnen realiseren. Een belangrijke conclusie van het vele onderzoek van de laatste decennia naar de rol van het sociale beleid voor de economische prestaties is, dat sociaal beleid een productieve functie kan hebben voor het bereiken van de economische doelen. Het is ook juist tegen deze achtergrond dat in het recente WRR-rapport De verzorgingsstaat herwogen een vergelijking van verzorgingsstaatarrangementen in verschillende landen gekoppeld is aan een vergelijking van de economische prestaties (WRR 2006: hoofdstuk 4).

Internationale vergelijkingen nemen ook een belangrijke plaats in de European Employment Strategy. Verbanden tussen instituties/beleid en bepaalde prestaties blijven daarbij een belangrijke plaats innemen. Zo toont bijvoorbeeld een rapport van de Europese Commissie voor negen van de dertien gepresenteerde EU-lidstaten een vrijwel volledige correlatie tussen het werkloosheidspercentage en het percentage van het bbp dat per werkende wordt besteed aan actief arbeidsmarktbeleid (EC 2005: fig. 12.3a).

Sociaal-economische relaties worden door veel factoren bepaald, en een vergelijking van diverse onderwerpen die de flexibiliteit en zekerheid van deelnemers aan de arbeidsmarkt in de verschillende landen belichten, is dan ook gewenst. Zo'n vergelijking kan duidelijk maken waar sterke en zwakke punten zitten, en 
aldus nuttig zijn om het verdere onderzoek richting te geven. De bundeling van de gegevens in de paragrafen 2.4-2.6 is overeenkomstig de thema's van de hoofdstukken 3-5, zij het in omgekeerde volgorde, teneinde met macro-economische kengetallen te kunnen beginnen. Ten aanzien van de insider-outsider-problematiek zal allereerst gekeken worden naar het vermogen van de arbeidsmarkten om de beroepsbevolking te absorberen. In het bijzonder zal daarbij gelet worden op de participatie van de kwetsbare groepen: ouderen, vrouwen (vanwege de combinatie van zorg en arbeid) en uitkeringsontvangers (par. 2.4). Met betrekking tot de overgang van de ene functie naar de andere, welke een betere allocatie van arbeid binnen een bedrijf tot doel heeft, wordt ingegaan op de arbeidsproductiviteit en op de verschillende flexibele vormen van arbeidscontracten (par.2.5). Ten slotte komt een vijftal aspecten aan de orde die met de overgang van baan naar baan te maken hebben: het activerend arbeidsmarktbeleid, de werkloosheidsregimes, de ontslagstelsels, de baancreatie en -vernietiging en de mobiliteit (par. 2.6). In de slotparagraaf (2.7) volgen enkele conclusies.

\subsection{HET VERMOGEN VAN ARBEIDSMARKTEN IN DE EU OM DE BEROEPSBEVOLKING TE LATEN PARTICIPEREN}

Het vergelijken van arbeidsmarktregimes in de vijftien lidstaten van de Europese Unie kan tot zoveel informatie leiden dat het overzicht eronder lijdt. Daarom is het gebruikelijk lidstaten onder te brengen in min of meer homogene clusters. In het rapport De verzorgingsstaat herwogen worden vier clusters onderscheiden, het Scandinavische, het continentale, het Angelsaksische en het mediterrane cluster. Voor de gehanteerde criteria, die met name institutionele arrangementen op een aantal terreinen betreffen, wordt verwezen naar dat rapport (WRR 2006: 76; zie ook Ferrera et al. 2003). Omdat Nederland in de bespreking toch voortdurend afzonderlijk zal worden belicht, wordt vanwege de continuïteit de indeling uit De verzorgingsstaat herwogen aangehouden.

\section{Werkgelegenheid en participatie}

Vanwege de wens te komen tot draagvlakversterking zal de participatiegraad zo hoog mogelijk moeten zijn. De participatiegraad zal hoger zijn naarmate de arbeidsmarkt er beter in slaagt mensen die nog niet werken op te nemen in het arbeidsproces, en mensen die werken voor het arbeidsproces te behouden.

Verschillen in participatiegraden illustreren niet alleen de prestaties van de nationale arbeidsmarkten. Er kunnen ook culturele verschillen aan ten grondslag liggen. Opvattingen over wie er wel en niet zou moeten en zou kunnen werken, lopen sterk uiteen als het gaat om mensen die werkloos zijn geworden, mensen die alleen maar laagbetaalde (en dus niet zelden onaantrekkelijke) arbeid kunnen verrichten, mensen die arbeidsongeschikt zijn, ouderen en moeders van jongere kinderen. De inrichting van de arbeidsmarkten kan deze verschillen in voorkeuren vergroten of verminderen. Maar ook kan de arbeidsmarkt toe- of herintreding vergemakkelijken dan wel tegengaan. 


\begin{tabular}{|l|l|l|} 
& 1985 & 2003 \\
Scandinavisch & & \\
Denemarken & & 75,1 \\
Finland & 73,9 & 67,4 \\
Zweden & 72,3 & 74,3 \\
Continentaal & 80,2 & \\
Duitsland & & 64,6 \\
Frankrijk & 61,6 & 62,5 \\
Nederland & 59,5 & 72,7 \\
België & 50,6 & 59,3 \\
Oostenrijk & 52,8 & 68,7 \\
Angelsaksisch & & \\
lerland & & 65 \\
Verenigd Koninkrijk & 50,1 & 72,6 \\
Mediterraan & 66,7 & 60,7 \\
Italië & & 56,9 \\
Portugal & 51,9 & 5,1 \\
Griekenland & 63,6 & \\
Spanje & 55,2 & \\
\hline
\end{tabular}

Bron: OECD

Hoewel de uitgangspunten of beleidsdoelen gelijkelijk prioriteit genieten in alle EU-lidstaten, zijn er op het punt van de participatiegraden interessante verschillen. Op het niveau van de clusters hebben de Scandinavische en de Angelsaksische landen een participatiegraad van 65 tot 75 procent, terwijl drie van de vier mediterrane landen een participatiegraad hebben van hooguit 60 procent. De continentale landen zitten globaal tussen 60 tot 70 procent met als uitschieter Nederland in 2003 met bijna 73 procent. Vergelijkt men afzonderlijke landen, dan varieert de participatie van ruim 56 procent (Italië) tot 75 procent (Denemarken).

Uit tabel 2.2 blijkt dat als in mensjaren in plaats van aantal personen wordt gemeten de verschillen kleiner worden. Deeltijdarbeid verkleint de bandbreedte tot 54-69 procent, en het grootste verschil tussen clusters van 20 tot 15 procentpunten. De meting in voltijdsequivalenten doet de achterstand van de mediterrane landen ten opzichte van de continentale verdwijnen, maar 'creëert' ook een verschil tussen de Scandinavische en Angelsaksische landen. Deeltijdbanen komen in de mediterrane landen sporadisch voor, dit vooral vanwege de daar relatief slechte bijbehorende arbeidsvoorwaarden. 
Tabel 2.2 Werkgelegenheid in voltijdsequivalenten als percentage van de beroepsbevolking

\begin{tabular}{|l|c|c|} 
& 1995 & 2004 \\
Scandinavisch & & \\
Denemarken & & 68,6 \\
Finland & 66,8 & 64,8 \\
Zweden & 56,5 & 66,2 \\
Continentaal & 63,9 & \\
Duitsland & & 56,6 \\
Frankrijk & 59,7 & 58,7 \\
Nederland & 56,6 & 56,5 \\
België & 51,4 & 55,8 \\
Oostenrijk & 53,4 & 61,6 \\
Angelsaksisch & 65,8 & \\
lerland & & 61,0 \\
Verenigd Koninkrijk & 50,8 & 61,6 \\
Mediterraan & 59,2 & 58,3 \\
Italië & & 54,3 \\
Portugal & 49,8 & 66,3 \\
Griekenland & 51,9 & 5,8 \\
Spanje & 54,2 & \\
\hline
\end{tabular}

Bron: Eurostat

De verschillen in participatie kunnen worden onderscheiden naar participatie van mannen en vrouwen. Terwijl de deelneming van alle personen 20 procentpunten uiteenloopt, is dit verschil maar de helft als het gaat om mannen. Dit weerspiegelt het grotere verschil in de deelneming van vrouwen waarbij de bandbreedte maar liefst 30 procentpunten bedraagt (van 43 tot 73 procent) met Italië in de laagste positie en Zweden aan top, zie tabel 2.3. 
Tabel 2.3 Werkgelegenheid vrouwen van 15-64 jaar

\begin{tabular}{|l|c|c|} 
& 1985 & 2003 \\
Scandinavisch & & \\
Denemarken & 57,4 & 70,5 \\
Finland & 69,8 & 65,7 \\
Zweden & 76,8 & 72,8 \\
Continentaal & & \\
Duitsland & 47,7 & 58,7 \\
Frankrijk & 48,5 & 56,5 \\
Nederland & 35,5 & 64,9 \\
België & 37,0 & 51,4 \\
Oostenrijk & & 61,5 \\
Angelsaksisch & & \\
lerland & 32,4 & 55,4 \\
Verenigd Koninkrijk & 55,6 & 66,4 \\
Mediterraan & & 46,5 \\
Italië & 33,4 & 42,7 \\
Portugal & 49,4 & 60,6 \\
Griekenland & 36,1 & 4,5 \\
Spanje & 25,8 & \\
\hline
\end{tabular}

Bron: OECD Labour Force Statistics

Een toespitsing op de participatiegraden van oudere werknemers (vanaf 55 jaar)

laat zien dat deze in alle Europese landen lager ligt dan het gemiddelde (figuur 2.1).

\section{Figuur 2.1 Werkgelegenheid oudere vrouwen en oudere mannen}

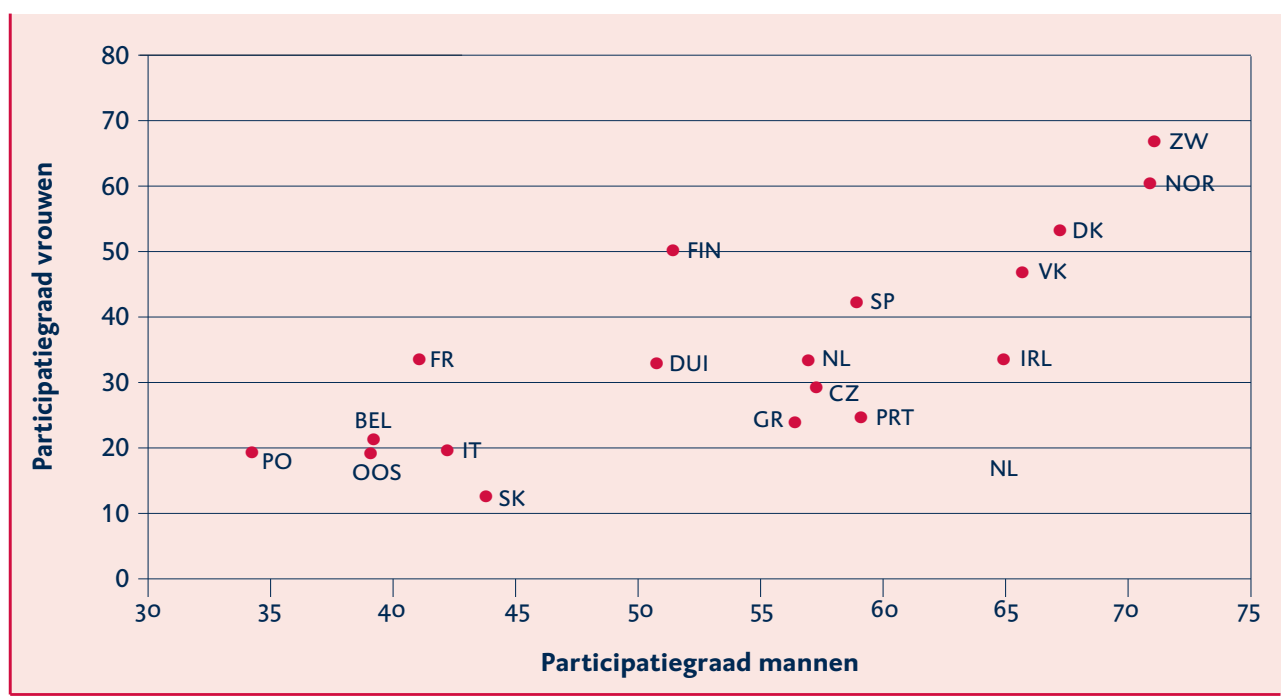

Bron: Eurostat, Structural Indicators 
De dominantie op de arbeidsmarkt van mannen in de mediterrane landen neemt nauwelijks af bij het vorderen van de leeftijd. Hun participatie is in Portugal, Griekenland en Spanje vrijwel gelijk aan die in Denemarken, Ierland en het VK. Alleen de Scandinavische landen en het VK vertonen voor deze leeftijdsgroep een voor mannen en vrouwen vergelijkbare score. De continentale landen scoren relatief slecht op beide categorieën.

\section{De rol van arbeidsmarktinstituties}

De invloed van arbeidsmarktinstituties blijkt onder meer uit de omvang van de groepen die de arbeidsmarkt hebben verlaten en een beroep doen op een publieke voorziening. De instroom, de verblijfsduur en de uitstroom van inkomensregelingen die een gederfd arbeidsinkomen compenseren zijn onderwerpen die zich gevoelig tonen voor de hoogte van de tegemoetkomingen en de condities waaronder zij worden verstrekt. Zijn de uitkeringen laag en de condities streng, dan zal dit de beslissing om van deze regelingen gebruik te maken, negatief beïnvloeden. Een goede maatstaf om betaalde inactiviteit te meten is de zogenaamde uitkerings-

Figuur 2.2 De uitkeringsafhankelijkheidsratio tot 65 jaar verdeeld naar mannen en vrouwen (1999)

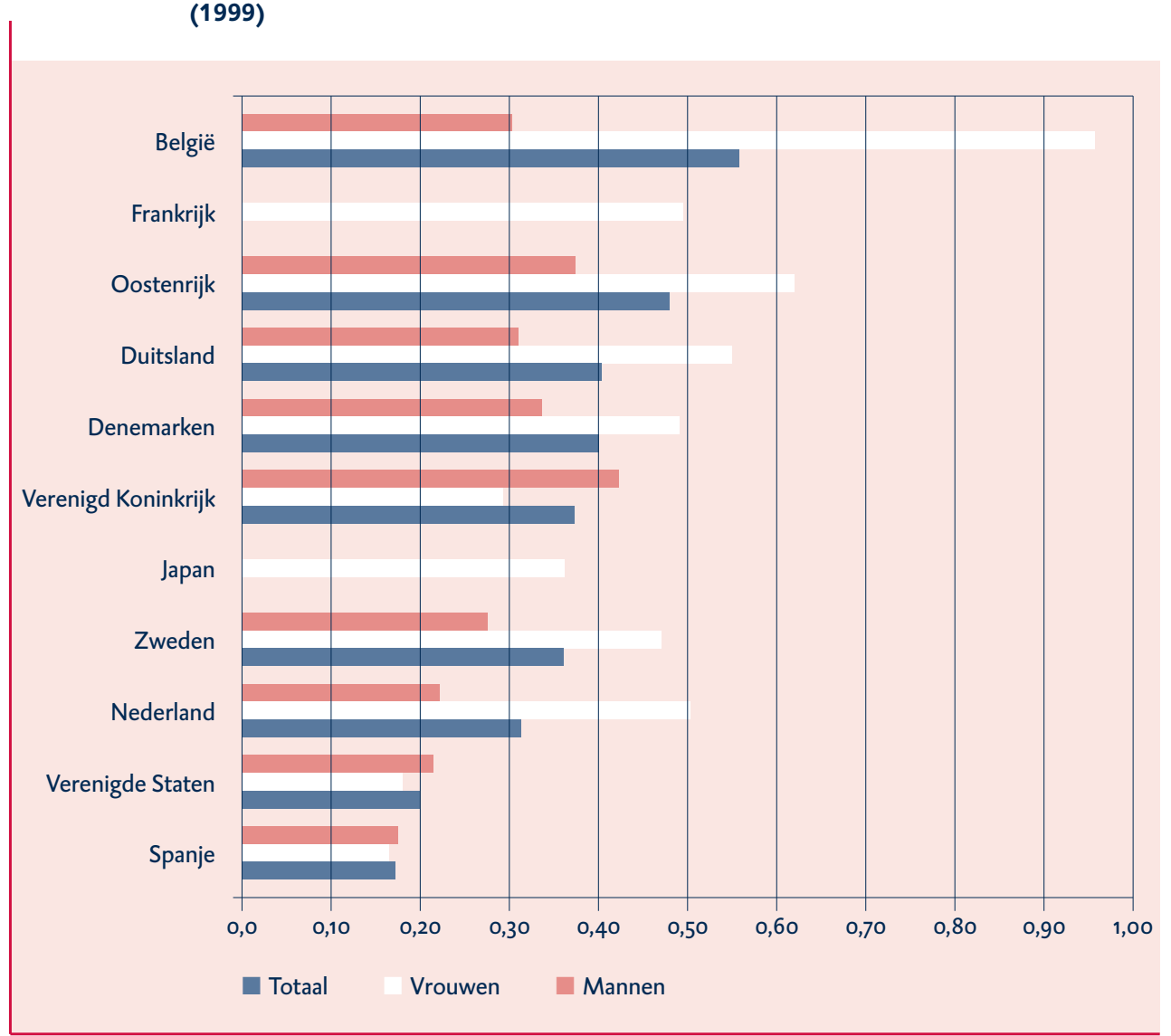

Bron: Moore et al. (200o) blz. 25 
afhankelijkheidsratio. Deze ratio geeft de verhouding aan van het aantal uitkeringsjaren in een land ten opzichte van het aantal arbeidsjaren. Voor wat betreft de werking van de arbeidsmarkt is het interessant om uitsluitend de uitkeringsjaren te bezien die worden verleend aan personen tot de leeftijd van 65 jaren (zie figuur 2.2).

Het totaal van uitkeringsjaren en arbeidsjaren is niet gelijk aan de beroepsbevolking, omdat er ook personen zijn die niet participeren maar ook geen beroep (kunnen) doen op een uitkering. In Nederland gaat het hierbij om circa i miljoen personen. Grosso modo (de afbakening van de bevolkingsgroep is afhankelijk van het wel of niet meenemen van leerplichtigen en studerenden) betreft dit tien procent van de beroepsbevolking, met andere woorden de inkomensdichtheid onder volwassenen is in ons land zo'n 90 procent. In Spanje, het enige land van het mediterrane cluster waarvan de uitkeringsafhankelijkheidsratio bekend is, is de situatie nogal anders. De ratio daar is met 17 procent belangrijk lager dan de Nederlandse 31 procent. Omdat ook de participatie er laag is zijn er dus veel personen zonder inkomen, die in hun levensonderhoud voorzien middels het huishouden waartoe zij behoren, en is de inkomensdichtheid met ongeveer 6 o procent ook duidelijk lager (Moor et al., tabel 2.1).

Figuur 2.2 toont uitkeringsafhankelijkheidsratio's die (in 1999) variëren van 56 procent in België tot 17 procent in Spanje; de Nederlandse 32 procent betekent een middenpositie. Variaties in deze ratio verdienen meer aandacht dan ze tot nu toe hebben gekregen. Het valt niet op voorhand te begrijpen waarom de kans op ziekte, arbeidsongeschiktheid of werkloosheid in de EU-lidstaten fors zou uiteenlopen. Het voorkomen van ziekte is niet met landsgrenzen verbonden en datzelfde geldt in zekere mate voor de economische conjunctuur die van veel invloed is op de kans op werkloosheid. Wel is het aannemelijk dat landen met een lage participatiegraad, en daarmee relatief weinig personen met een primair inkomen, een groter beroep op bijstandsregelingen vertonen dan landen met juist een hoge primaire inkomensdichtheid. De vergelijking van de ratio's van Spanje en Denemarken van 17 respectievelijk 40 procent laat evenwel zien dat deze verklaring weinig gewicht in de schaal legt. Van de andere kant zou een hogere arbeidsparticipatie tot een meer dan evenredig beroep op uitkeringen kunnen leiden, omdat de grotere participatie personen zou kunnen betreffen die minder gemotiveerd of toegerust zouden kunnen zijn dan de personen die zich tout court kwalificeren voor de arbeidsmarkt. Deze verklaring is eveneens ontoereikend, omdat de ratio's niet progressief toenemen met het stijgen van de arbeidsparticipatie. Ook de verschillen in participatie naar sekse zijn niet gemakkelijk te duiden. Het beroep op uitkeringen door vrouwen is over het algemeen tweemaal zou groot als dat door mannen. Voor zover het gaat om zwangerschapsverlof is dit verschil gemakkelijk te verklaren. Maar de verklaring dat de dubbele belasting van vrouwen tot meer uitval leidt uit hoofde van ziekte en arbeidsongeschiktheid, zou weer impliceren dat landen met de hoogste participatie van vrouwen ook de hoogste ratio kennen, hetgeen niet het geval blijkt te zijn. Nationale verschillen in generositeit van de inkomensvoorzieningen lijken een onmisbare verklaringsgrond voor een belangrijk deel van de verschillen. 
In internationale vergelijkingen wordt de werkloosheid vaak als een belangrijke maatstaf gezien om het functioneren van arbeidsmarkten te beoordelen. Werkloosheidsstatistieken registreren het aantal personen zonder een baan, dat actief op zoek is naar betaalde arbeid. Omdat conjuncturele schommelingen een belangrijke internationale component hebben, registreren verschillen in werkloosheid in belangrijke mate het vermogen van landen om evenwicht aan te brengen tussen vraag en aanbod op hun arbeidsmarkten. Omdat vraag en aanbod naar regio, werkervaring, opleiding en werktijden kunnen uiteenlopen, zegt het werkloosheidspercentage dus bij uitstek wat over het aanpassingsvermogen van de verschillende lidstaten. Werkloosheidspercentages variëren sterk in de EU. De meeste mediterrane en continentale landen zitten in een bandbreedte van 7,5 tot 1o procent, de Scandinavische en Angelsaksische landen in een range van 4 tot 5 procent (zie tabel 2.4). De langdurige werkloosheid geeft een nog betere indicatie voor de prestaties van het arbeidsmarktbeleid. Uit tabel 2.4 blijkt immers dat de hoogte van de werkloosheid niet van invloed is op de hoogte van de langdurige werkloosheid.

\section{Tabel 2.4 Werkloosheid}

\begin{tabular}{|c|c|c|c|c|c|c|c|c|}
\hline & 1995 & 2000 & 2003 & $\begin{array}{r}1995- \\
2003\end{array}$ & 1995 & 2000 & 2003 & $\begin{array}{r}1995 \\
2003\end{array}$ \\
\hline & \multicolumn{4}{|c|}{ Totaal } & \multicolumn{4}{|c|}{ Langdurig } \\
\hline Scandinavisch & & & & & & & & \\
\hline Denemarken & 6,8 & 4,4 & 5,6 & $-1,2$ & 27,9 & 20 & 19,9 & -8 \\
\hline Zweden & 8,8 & 5,6 & 5,6 & $-3,2$ & 27,8 & 26,4 & 17,8 & -10 \\
\hline Continentaal & & & & & & & & \\
\hline Duitsland & 8 & 7,8 & 9,3 & 1,3 & 48,7 & 51,5 & 50 & 1,3 \\
\hline Nederland & 6,6 & 2,9 & 3,8 & $-2,8$ & 46,8 & 26,7 & 29,2 & $-17,6$ \\
\hline België & 9,7 & 6,9 & 8,1 & $-1,6$ & 62,4 & 51,7 & 46,3 & $-16,1$ \\
\hline Anglo-Saksisch & & & & & & & & \\
\hline lerland & 12,3 & 4,3 & 4,6 & $-7,7$ & 61,4 & 33,1 & 35,4 & -26 \\
\hline Verenigd Koninkrijk & 8,5 & 5,4 & 5 & $-3,5$ & 43,7 & 28 & 23 & $-20,7$ \\
\hline
\end{tabular}

* Langdurige werkloosheid staat voor langetermijn werkloosheid ( $>1$ jaar) als percentage van het totaal aantal werklozen

Bron: OECD Employment Outlook 2005

Een andere illustratie van de kwaliteit van arbeidsmarkten kan worden ontleend aan de Nairu. De Nairu ('Non accelerating inflation rate of unemployment'), ofwel de structurele werkloosheid geeft het (minimale) werkloosheidspercentage aan waarbij zich nog geen knelpunten voordoen die leiden tot inflatoire druk. Hoe lager de Nairu-waarde, hoe beter een land in staat is om met weinig aanbod van werkzoekenden toch de arbeidsmarkt adequaat te kunnen voorzien. De Nairu 
wordt bepaald door structurele kenmerken van de arbeidsmarkt, zoals de sociale zekerheid, ontslagbescherming en het arbeidsmarktbeleid. Volgens een recente studie behoort de Nairu in Nederland tot de laagste in Europa (EC 2006).

Ondanks het feit dat werkloosheidspercentages een duidelijke indicator vormen van het aanpassingsvermogen van de arbeidsmarkten in de onderscheiden landen, is deze indicator wel beperkt tot het absorptievermogen van de arbeidsmarkt van werkzoekenden. Wie wel wil werken, maar niet beschikbaar is, of wie wil werken maar daar in actieve zin geen blijk van geeft, valt buiten de werkloosheidsstatistieken. Zo blijkt voor Nederland dat de werkloosheidsdefinitie op iets minder dan de helft van alle werkwilligen betrekking heeft (СРВ 2006: 100). Zij willen in beginsel wel werken, maar vertonen te geringe zoekactiviteiten om als werkloos te boek te staan. Een arbeidsmarktregime dat zo passief is dat het geen eisen stelt aan beschikbaarheid of aan actief zoekgedrag, zal daarom een lagere werkloosheid kennen dan een land dat zich in deze opzichten minder passief betoont.

Geconcludeerd kan worden dat de uitkeringsafhankelijkheid een te ruime maatstaf vormt, omdat ook zieken en volledig arbeidsongeschikten die niet beschikbaar kunnen zijn voor de arbeidsmarkt worden meegeteld, terwijl de gehanteerde werkloosheid te eng lijkt om de werking van de arbeidsmarkten te beoordelen.

\subsection{ARBEIDSPRODUCTIVITEIT EN FLEXIBELE ARBEIDSRELATIES}

De arbeidsproductiviteit meet de hoeveelheid nationaal product die per werknemer wordt voortgebracht. Omdat voltijdbanen in verschillende landen tot verschillende aantallen gewerkte uren optellen en vanwege de aanwezigheid van deeltijdbanen, lopen de aantallen gewerkte uren fors uiteen, van 1.350 per jaar in Nederland tot bijna 1.950 in Griekenland. Daarom vormt de arbeidsproductiviteit per gewerkt uur de beste vergelijkingsmaatstaf. Nederland behoort tot de Europese landen met de hoogste arbeidsproductiviteit, beduidend hoger dan de Scandinavische landen. Omdat in de Scandinavische landen meer gewerkt wordt dan in Nederland, zou men er een hoger inkomen per hoofd verwachten. Dit is evenwel niet het geval (СРB 2006: 35). Naast algemene factoren zoals de hoeveelheid fysiek en menselijk kapitaal waarover een land kan beschikken, is de flexibiliteit bij uitstek medebepalend voor de hoogte van de arbeidsproductiviteit. Wanneer de flexibiliteit zodanig is dat productiemiddelen steeds op de meest rendabele wijzen kunnen worden ingezet, zal de arbeidsproductiviteit hierdoor sneller toenemen. In zoverre zegt de hoogte van de Nederlandse arbeidsproductiviteit dus ook wat over de flexibiliteit op de arbeidsmarkt.

Wordt gekeken naar de ontwikkeling in de tijd van de arbeidsproductiviteit, dan is het beeld bij vergelijking van Nederland met het OESO-gebied wat minder geruststellend. Voor de periode 1997 tot en met 2006 beloopt de productiviteitsontwikkeling in ons land gemiddeld één procent, tegenover 1,7 procent voor de OESO als geheel. Dit verschil verandert niet als we niet tien maar vijf jaar terugkijken 
Figuur 2.3 Productiviteit per werknemer en per gewerkt uur

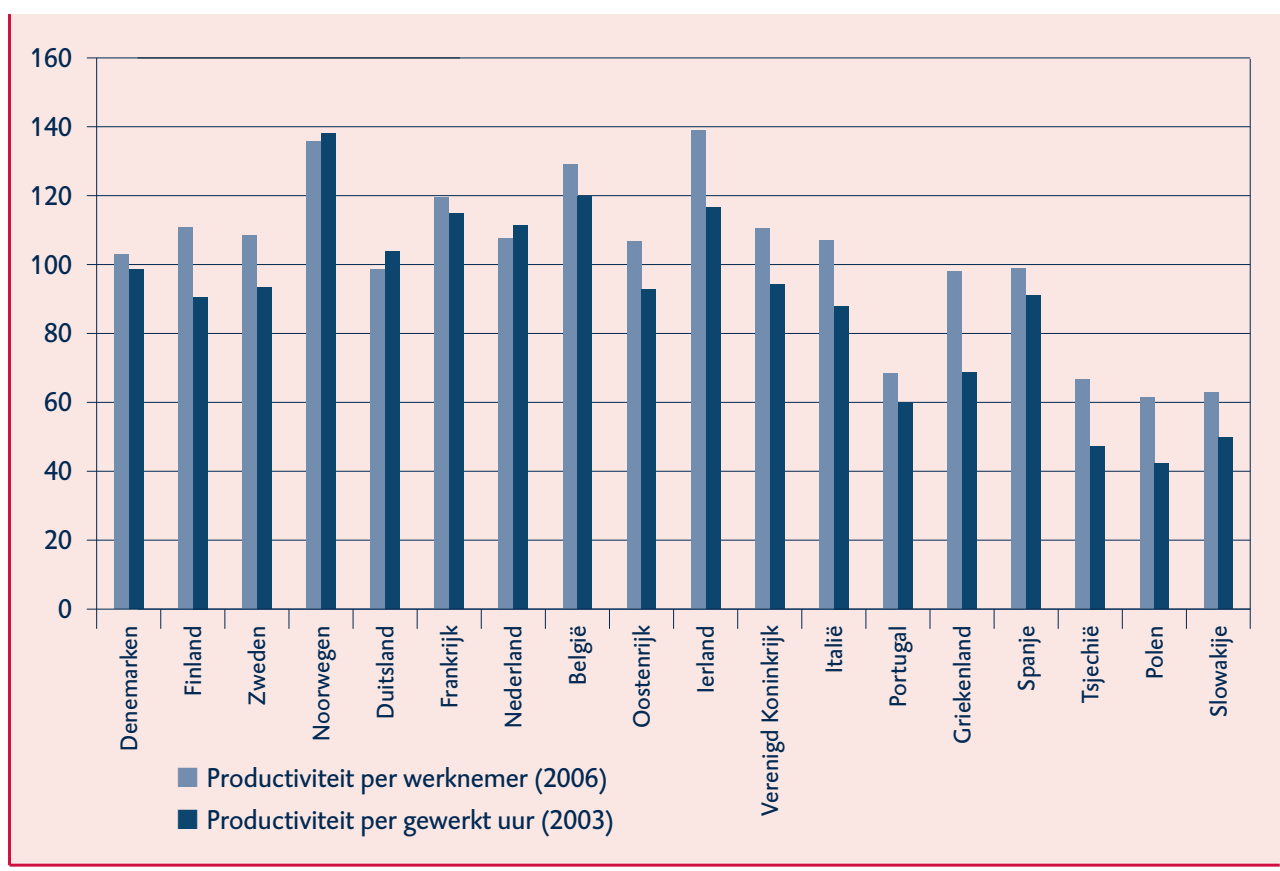

Bron: Eurostat, Sustainable Development Indicators

(OECD 2006: 176). Dat de Nederlandse productiviteitsontwikkeling het wat beter doet ten opzichte van het eurogebied (o.8 procent) is nauwelijks een relativering in een context waarbij de globalisering de uitdaging vormt.

De meest voorkomende vorm van een arbeidscontract is er een voor onbepaalde tijd, met andere woorden een vast contract. Vaste contracten kunnen voltijdbanen en deeltijdbanen betreffen. Naast vaste contracten zijn er tijdelijke contracten en uitzendbanen. Tijdelijke banen, proeftijden en uitzendbanen kunnen de aanloop vormen van een vast contract. Als de arbeidsrelatie niet voldoet, kan de werkgever op grond van de overeengekomen beperkte duur afscheid nemen van de werknemer. Daarnaast kan de werkgever ook personeel inhuren voor bepaalde tijd omdat de werkzaamheden tijdsgebonden zijn. Tijdelijke banen en uitzendbanen hebben in die gevallen een evident voordeel. In de volgende tabel worden de beschikbare data op dit punt gepresenteerd. Duidelijk blijkt dat Nederland de hoogste score heeft van deeltijdbanen en tijdelijke banen ten opzichte van de landen die zijn gepresenteerd. De deeltijdbaan is een contractvorm die primair de arbeidsdeelname van werknemers vergemakkelijkt, en als zodanig bijdraagt aan de flexibiliteit van de arbeidsmarkt. 
Tabel 2.5 Vormen van flexibele arbeidsrelaties

\begin{tabular}{|c|c|c|c|c|c|c|c|c|}
\hline & \multicolumn{2}{|c|}{ Deeltijdbanen } & \multicolumn{2}{|c|}{$\begin{array}{l}\text { Tijdelijke } \\
\text { contracten }\end{array}$} & \multicolumn{2}{|c|}{$\begin{array}{l}\text { Uitzend- } \\
\text { werknemers }\end{array}$} & \multicolumn{2}{|c|}{$\begin{array}{l}\text { Aandeel zelf- } \\
\text { standige arbeid }\end{array}$} \\
\hline & 2003 & $\begin{array}{l}1994- \\
2003\end{array}$ & 2003 & $\begin{array}{l}1993- \\
2003\end{array}$ & 2004 & $\begin{array}{l}1999- \\
2004\end{array}$ & 2003 & $\begin{array}{l}1993- \\
2003\end{array}$ \\
\hline \multicolumn{9}{|l|}{ Scandinavië } \\
\hline Denemarken & 15,8 & $-1,3$ & 9,3 & $-1,3$ & 1,2 & 1 & 7,1 & $-2,1$ \\
\hline $\begin{array}{l}\text { Zweden } \\
\text { Continent }\end{array}$ & 14,1 & $-1,7$ & 15,5 & 3,5 & 1 & 0,5 & 4,9 & $-0,6$ \\
\hline Nederland & 34,5 & 8 & 14,5 & 4 & 2,5 & -2 & 13,9 & $-1,7$ \\
\hline Duitsland & 19,6 & 6,1 & 12 & 1,7 & 1 & 0,3 & 10,2 & 0,5 \\
\hline $\begin{array}{l}\text { Frankrijk } \\
\text { Angelsaksisch }\end{array}$ & 12,9 & 0,6 & 12,7 & 1,8 & 2,1 & 0,1 & 8,8 & $-2,8$ \\
\hline Verenigd Koninkrijk & 23,3 & 1,1 & 6,1 & $-0,2$ & 5 & 1,4 & 12,7 & $-0,8$ \\
\hline Verenigde Staten & \multicolumn{2}{|c|}{$\begin{array}{l}\text { (als \% van alle } \\
\text { banen) }\end{array}$} & \multicolumn{2}{|c|}{$\begin{array}{l}\text { (als \% van alle } \\
\text { contracten) }\end{array}$} & \multicolumn{2}{|c|}{$\begin{array}{l}\text { (als \% van alle } \\
\text { werknemers) }\end{array}$} & 7,6 & $-1,2$ \\
\hline
\end{tabular}

Bron: Visser (2006)

\subsection{ASPECTEN VAN TRANSITIES VAN BAAN NAAR BAAN}

Veel overheidsbeleid heeft als oogmerk het reguleren van de arbeidsmarkt of heeft daar op indirecte wijze invloed op. Op dit moment krijgen met name drie arrangementen de aandacht van beleidsmakers en wetenschappers, vanwege hun onderlinge interdependenties: het activerende arbeidsmarktbeleid, de ontslagwetgeving en de werkloosheidsregelingen. Voor Denemarken wordt, met een verwijzing naar de veronderstelde goede balans tussen deze drie arrangementen, gesproken van 'de gouden driehoek' (OECD 2004: 97). Het beeld van de driehoek duidt op de onderlinge afhankelijkheid. Verschillende combinaties zijn denkbaar. Zo zou een hoge mate van ontslagbescherming een erg genereuze werkloosheidsregeling overbodig maken, terwijl een lage mate goed zou samengaan met een gunstige werkloosheidsregeling. Ook op deze aspecten wordt hier ingegaan.

Voor wat betreft het activerende arbeidsmarktbeleid toont tabel 2.6 dat Nederland samen met Denemarken het hoogste percentage van het bbp hiervoor reserveert. 
Tabel 2.6

Publieke sociale uitgaven als percentage van het BBP

\begin{tabular}{|c|c|c|}
\hline & Totaal & $\begin{array}{r}\text { Actief arbeids- } \\
\text { marktbeleid }\end{array}$ \\
\hline \multicolumn{3}{|l|}{ Scandinavisch } \\
\hline Denemarken & 29,2 & 1,52 \\
\hline Finland & 24,8 & 0,95 \\
\hline Zweden & 28,9 & 1,36 \\
\hline \multicolumn{3}{|l|}{ Continentaal } \\
\hline Duitsland & 27,4 & 1,11 \\
\hline Frankrijk & 28,5 & 1,29 \\
\hline Nederland & 21,8 & 1,54 \\
\hline België & 27,2 & 1,26 \\
\hline Oostenrijk & 26,0 & 0,52 \\
\hline \multicolumn{3}{|l|}{ Angelsaksisch } \\
\hline lerland & 13,8 & 0,70 \\
\hline Verenigd Koninkrijk & 21,8 & 0,35 \\
\hline \multicolumn{3}{|l|}{ Mediterraan } \\
\hline Italië & 24,4 & 0,47 \\
\hline Griekenland & 24,3 & 0,18 \\
\hline Portugal & 21,1 & 0,59 \\
\hline Spanje & 19,6 & 0,83 \\
\hline
\end{tabular}

Bron: OECD Social Expenditure Database

Hoewel, zoals ook blijkt uit deze tabel, Nederland minder kwijt is aan het totaal van de sociale uitkeringen (hetgeen te maken heeft met de relatief gunstige uitkeringsafhankelijkheidsratio), geldt dat niet voor de werkloosheidsuitkeringen, zoals figuur 2.4 duidelijk maakt. Zeker wanneer dit gerelateerd wordt aan de relatief lage werkloosheid, geeft Nederland meer uit aan werkloosheidsuitkeringen dan andere Europese landen. Overigens is er juist op dit onderdeel recent veel nieuwe wetgeving tot stand gebracht die naar verwachting een matigend effect op de uitgaven voor de ww zal hebben. 
Figuur 2.4 Werkloosheidsuitkeringen als percentage van het BNP en gestandaardiseerde werkloosheidscijfers (2003)

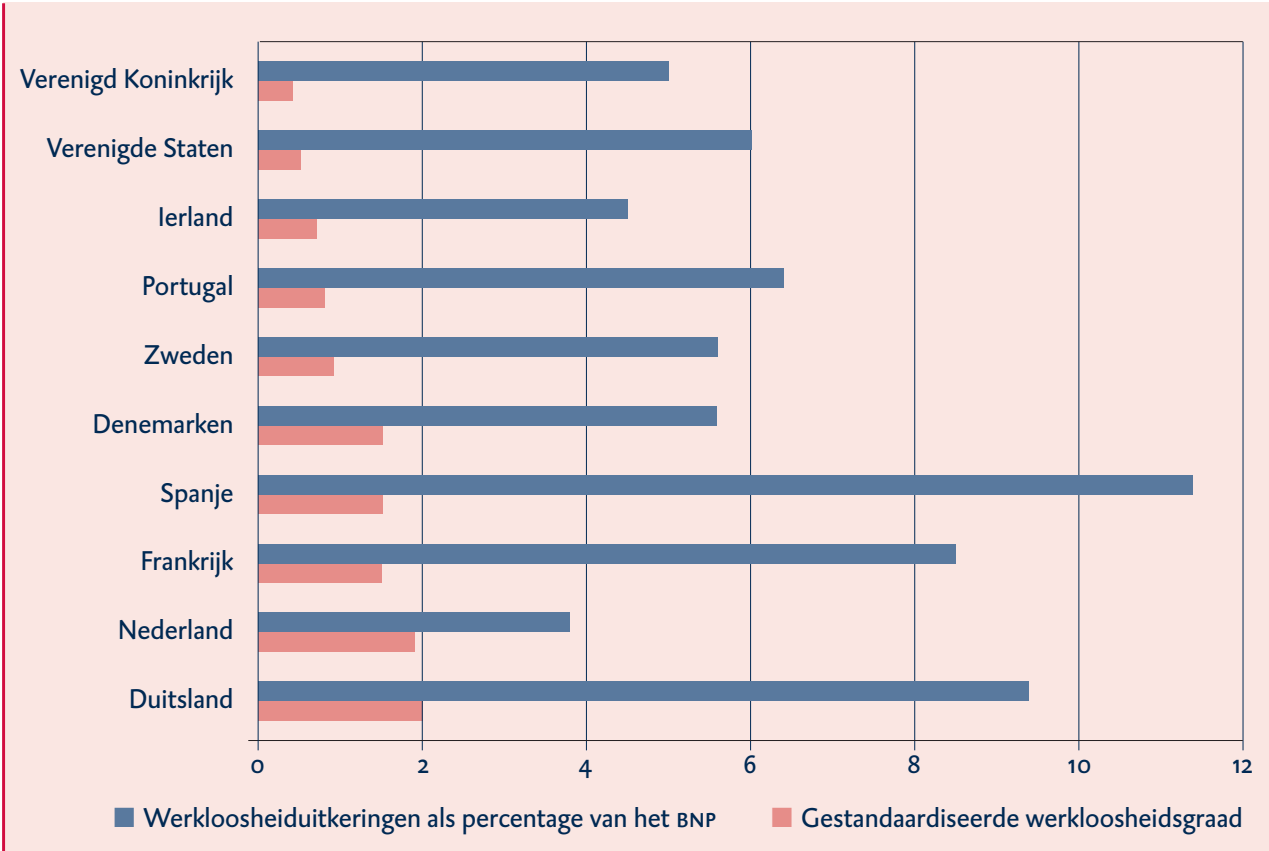

Bron: R.A. de Mooij, Towards efficient unemployment insurance in the Netherlands, СРВ Memorandum, 13 oktober 2004

Voor wat betreft de ontslagbescherming geeft figuur 2.5 (EPL = Employment Protection Regulation) de posities van de verschillende landen weer, waaruit blijkt dat Nederland een middenpositie inneemt. De oEso heeft in haar analyses van de ontslagbescherming ook onderscheid gemaakt naar vaste en tijdelijke banen, waaruit blijkt dat de verandering in de afgelopen decennia vooral het gevolg is van de versoepelingen die in Nederland zijn aangebracht ten aanzien van de ontslagmogelijkheden uit tijdelijke banen. Voorts blijkt dat het vooral de hoogte van de ontslagvergoedingen is die de relatief hoge positie van Nederland verklaart (Deelen et al. 20o6: 17). 
Figuur 2.5 OESO indicator van ontslagbescherming, eind jaren 80 en 2003

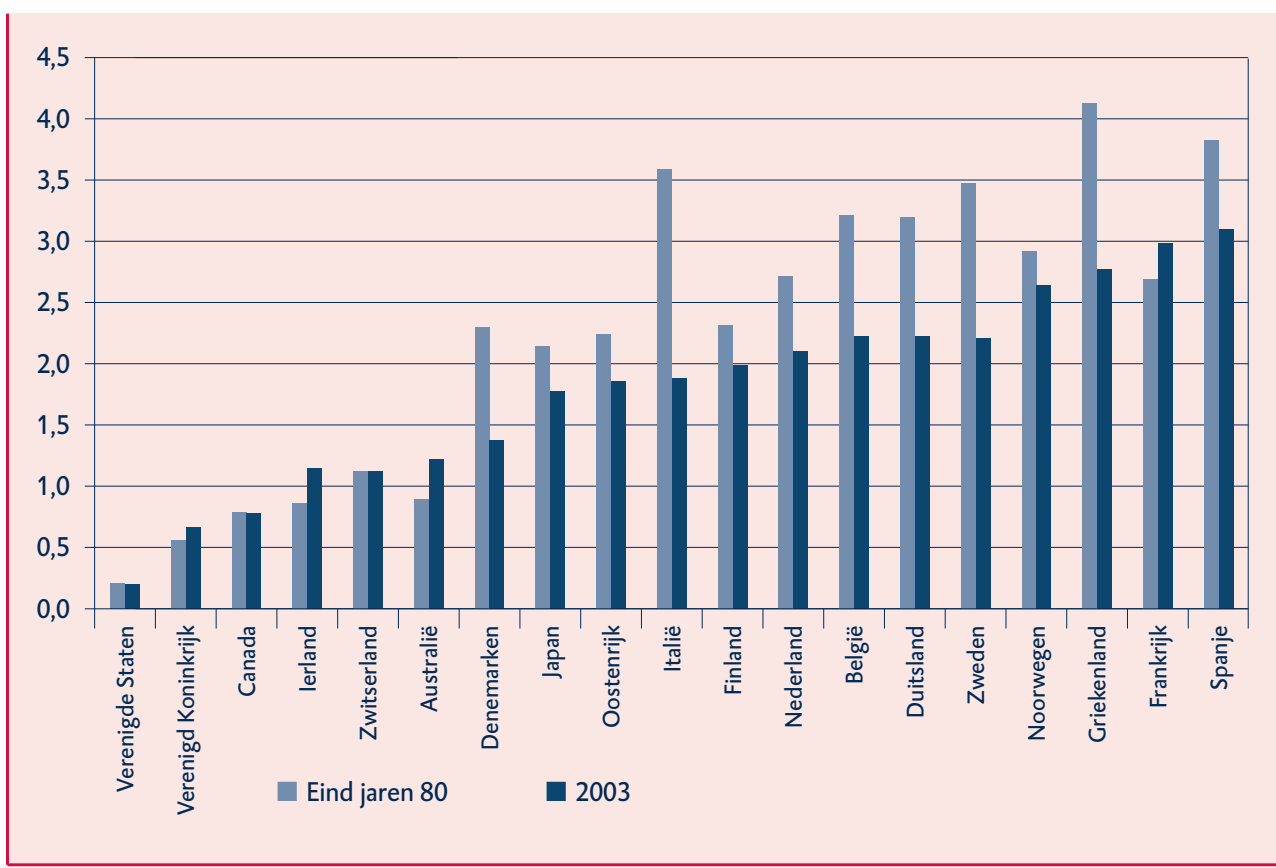

Bron: OESO

De hierboven genoemde factoren dragen, naast de economische ontwikkelingen, bij aan de arbeidsmarktdynamiek. Figuur 2.6 geeft de algemene indicatoren van arbeidsmarktdynamiek: baancreatie en baandestructie.

\section{Figuur 2.6 Internationale Baancreatie en - destructie}

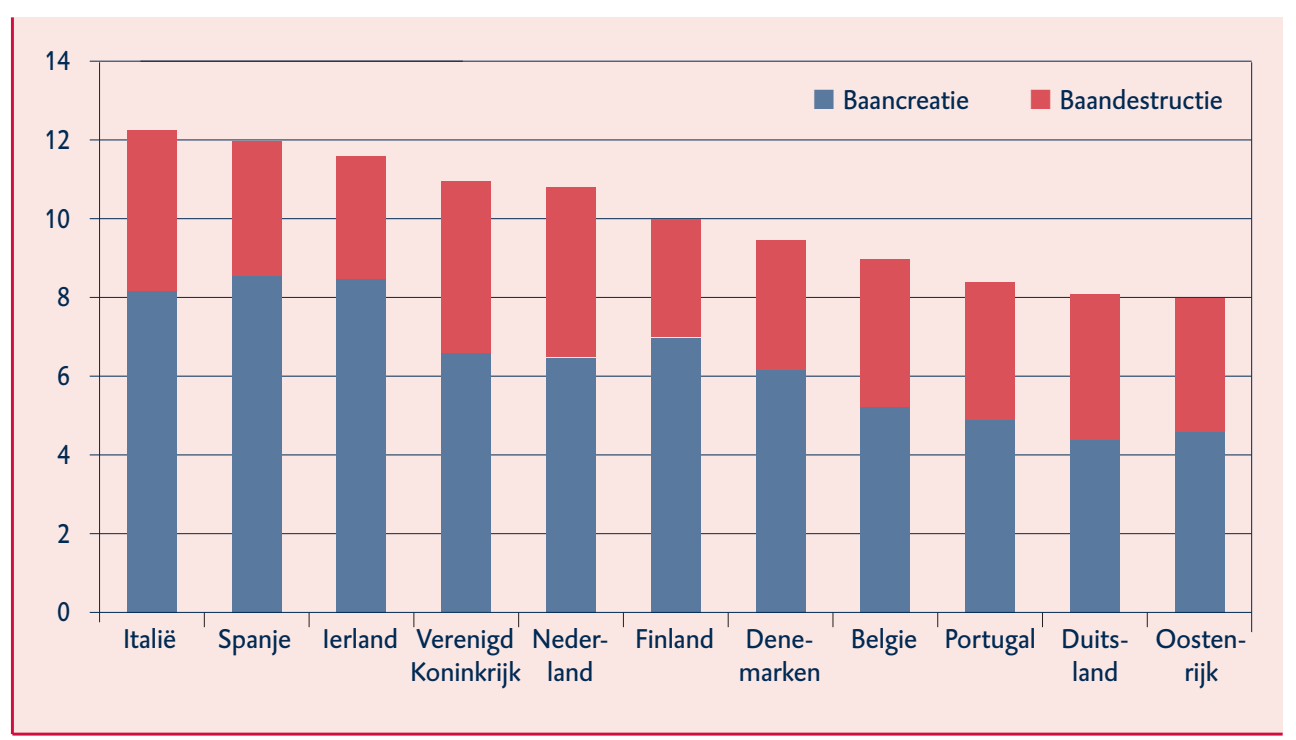

Bron: Gomez-Salvador et al. 2004 
Voor wat betreft baancreatie neemt Nederland de exacte middenpositie in, maar met betrekking tot baandestructie is de positie van Nederland relatief ongunstig, namelijk, samen met Engeland het hoogste percentage. Immers, hoe geringer de baandestructie, hoe groter, gegeven de baancreatie, de werkgelegenheidsgroei. Baancreatie zal door een fase van opgaande conjunctuur worden versterkt, terwijl baandestructie juist door een neergaande conjunctuur wordt gestimuleerd. Het feit dat Nederland, in afwijking van de meeste andere EU-landen, in de tweede helft van de jaren negentig een enigszins dalende banengroei kende, zullen de cijfers voor Nederland derhalve in ongunstige zin zijn beïnvloed (Gómez-Salvador et al. 2004: fig. 1). Het is aannemelijk dat de externe flexibiliteit mede wordt beïnvloed door de arbeidsmarktinstituties. Een strikte ontslagbescherming en een genereuze werkloosheidsuitkering zullen de dynamiek op de arbeidsmarkt niet ten goede komen.

Het ontstaan van nieuwe banen en het verdwijnen van bestaande banen leiden onvermijdelijk tot mutaties. Daarnaast zullen er ook veel veranderingen van banen optreden als gevolg van mutaties die niet samenhangen met de hoeveelheid banen maar wel met de bezetting ervan. In tabel 2.7 staan de cijfers voor het procentuele aantal baanwisselingen. Geteld zijn degenen die de afgelopen twee jaren van baan zijn veranderd zonder dat zij langer dan drie maanden werkloos zijn geweest (SCP 2005: 16). Samen met de Angelsaksische en Scandinavische landen behoort Nederland tot de groep van landen met de meeste baanwisselin-

Tabel 2.7 Externe baanmobiliteit in Europa 1994-2001 in \%

\begin{tabular}{|c|c|c|c|c|}
\hline & Rang 1994-2001 & 1994 & 2001 & Rang 2001 \\
\hline \multicolumn{5}{|l|}{ Scandinavië } \\
\hline Denemarken & 2 & 13,6 & 21 & 4 \\
\hline Finland & 5 & & 20 & 6 \\
\hline \multicolumn{5}{|l|}{ Continent } \\
\hline Oostenrijk & 8 & & 11,2 & 8 \\
\hline België & 10 & 5,2 & 10,6 & 9 \\
\hline Duitsland & 10 & 5,8 & 9,3 & 10 \\
\hline Nederland & 6 & 6,7 & 20,1 & 5 \\
\hline \multicolumn{5}{|l|}{ Angelsaksisch } \\
\hline Verenigd Koninkrijk & 1 & 15,9 & 24 & 1 \\
\hline lerland & 3 & 11,6 & 23,4 & 2 \\
\hline \multicolumn{5}{|l|}{ Mediterraan } \\
\hline Italië & 12 & 4,2 & 8,8 & 11 \\
\hline Griekenland & 9 & 7,2 & 8,2 & 12 \\
\hline Spanje & 4 & 7,6 & 21,8 & 3 \\
\hline Portugal & 7 & 6,6 & 13,3 & 7 \\
\hline
\end{tabular}

Bron: SCP (2005) 
gen. (Spanje vormt een wat vreemde eend in de bijt, omdat in dit land de banengroei samen met die in Ierland beduidend hoger was dan in de andere landen.)

\subsection{CONCLUSIES}

In paragraaf 2.3 zijn diverse tekortkomingen van de Nederlandse arbeidsmarkt gesignaleerd. Kwetsbare groepen zoals ouderen, laagopgeleiden en vrouwen vertonen veel lagere participatiecijfers dan het gemiddelde. Uitkeringsontvangers weten slechts moeizaam de weg naar de arbeidsmarkt te vinden. De arbeidsmarkt lijkt ook onvoldoende klaar voor de uitdagingen in de toekomst.

De internationale vergelijking laat zien dat Nederland met deze problemen bepaald niet alleen staat. Ten aanzien van vier indicatoren, participatie van ouderen, ontslagbescherming, baancreatie en mobiliteit, nemen we een middenpositie in. Ten aanzien van de werkloosheid, uitkeringsafhankelijkheid, flexibele arbeidsrelaties en de sociale uitgaven scoren we gunstig. Met betrekking tot de totale werkgelegenheid is de situatie opmerkelijk: in personen gemeten is onze participatiegraad op twee landen na het hoogst. Maar in voltijdbanen gemeten is deze op twee landen na het laagst. Vanuit het oogpunt van het economisch draagvlak bezien, telt dit laatste, omdat de hoeveelheid gewerkte uren telt en niet de spreiding over de populatie.

Juist met het oog op de vergrijzing is dit zorgelijk. Thans doet zich opnieuw een toenemende krapte op de arbeidsmarkt voor, met als gevolg druk op de lonen. Deze krapte wordt in de komende jaren steeds groter door de vergrijzing.

In 2007 daalt daardoor het arbeidsaanbod met 40.000 personen. Omdat de werkgelegenheid met 100.0oo toeneemt, zal dus door een verhoging van de participatie in de vacatures (voor bestaande en voor nieuwe banen) voorzien moeten worden (СРB 2006a: 95-105). Dit illustreert helder de sterk toegenomen noodzaak om de transities op de arbeidsmarkt te vergemakkelijken, de uitstroom tegen te gaan en de instroom te bevorderen. 
Externe flexibiliteit betreft volumeaanpassingen in de inzet van arbeid binnen bedrijven. Het gaat aan de ene kant om aanpassingen in de arbeidstijd van werknemers, aan de andere kant om aanpassingen in het aantal werknemers dat in dienst is. Externe flexibiliteit heeft als zodanig veel van doen met externe mobiliteit. Onder externe mobiliteit op de arbeidsmarkt worden de werknemersstromen in en uit bedrijven en instellingen verstaan. De aandacht in dit hoofdstuk gaat vooral uit naar de externe mobiliteit.

Externe mobiliteit kan voor werkgevers en werknemers zowel nadelen als voordelen inhouden. Werkgevers hebben voor aanpassingen van het personeelsbestand aan veranderingen in de vraag naar arbeid baat van externe mobiliteit. Door het vertrek van werknemers ontstaan echter vacatures die weer vervuld moeten worden. Externe mobiliteit dient ook werknemers bij het verbeteren van hun positie op de arbeidsmarkt. Het kan echter ook het verlies van een baan betekenen.

\section{$3.1 \quad$ INLEIDING}

Onder de oppervlakte van de veranderingen in de omvang van de werkzame beroepsbevolking gaan stromen schuil van werknemers in en uit bedrijven en instellingen die de veranderingen in de beroepsbevolking vele malen overtreffen. Ook de veranderingen in de omvang van de werkgelegenheid zijn vele malen kleiner dan de veranderingen in de omvang van de baanvernietiging en de baanschepping. In dit hoofdstuk worden de verschillende stromen op de arbeidsmarkt in kaart gebracht.

Externe mobiliteit op de arbeidsmarkt is sterk verbonden met de loopbaan van werknemers. Aan het begin van de loopbaan dient externe mobiliteit onder meer om de eigen capaciteiten en preferenties ten aanzien van arbeid te verkennen en om een baan te vinden waarin men zich op zijn plek voelt. Gedurende de loopbaan kunnen werknemers afhankelijk van de met de levensloop samenhangende preferenties tijdelijk of gedeeltelijk de arbeidsmarkt verlaten in verband met activiteiten als zorg en onderwijs. Aan het einde van de loopbaan trekken werknemers zich via diverse routes en in wisselend tempo van de arbeidsmarkt terug.

Arbeidsmarktstromen hebben een relatie met het thema van flexibiliteit en zekerheid. Externe flexibiliteit is een van de wegen waarlangs werkgevers aanpassingen aan veranderde omstandigheden kunnen bewerkstelligen. Externe flexibiliteit is een belangrijke bron van productiviteitsgroei. Voor werknemers is externe flexibiliteit van belang om speelruimte te scheppen in verband met activiteiten buiten het domein van de arbeid, terwijl het tegelijkertijd ook sterk verbonden is met de zekerheid van werknemers. Het verlies van baan en inkomen en de vraag of een nieuwe baan kan worden gevonden hebben immers alle met die zekerheid te maken. 
In dit hoofdstuk is de vraag aan de orde hoe groot de externe mobiliteit in Nederland is en wat de ontwikkeling in de tijd is geweest. Wat voor invloed heeft de externe mobiliteit op de productiviteit van de bedrijvigheid en wat betekent externe mobiliteit voor de werknemer?

Het hoofdstuk is als volgt opgebouwd. In paragraaf 3.2 wordt ingegaan op de stromen in en uit de arbeidsmarkt en in en uit werkloosheid. In de derde paragraaf komen baanwisselingen aan de orde; er wordt een relatie gelegd tussen de creatie en de destructie van banen en vrijwillige en onvrijwillige mobiliteit van werknemers. In paragraaf 3.4 wordt ingegaan op de bijdrage van creatieve destructie van banen en van baanwisselingen aan de productiviteitsgroei. Verder wordt de relatie van externe flexibiliteit met de opbouw van menselijk kapitaal besproken. In paragraaf 3.5 worden enkele conclusies getrokken.

\subsection{VERANDERINGEN VAN ARBEIDSMARKTSTATUS}

Het stromenmodel van de transitionele arbeidsmarkt (Schmid 1995), dat in hoofdstuk 1 al in hoofdlijnen is beschreven, brengt de veranderingen van arbeidsmarktstatus van werknemers in beeld. Vaak hebben werknemers een meervoudige status waarin activiteiten binnen en buiten de arbeidsmarkt worden gecombineerd. De kern van de arbeidsmarktstatus is echter of men tot de beroepsbevolking gerekend kan worden of dat er sprake is van werkloosheid.

\subsubsection{DE TRANSITIONELE ARBEIDSMARKT}

Wisselingen van arbeidsmarktstatus zijn vanouds verbonden met de levensloop. Onder arbeidsmarktstatus wordt de relatie met de arbeidsmarkt verstaan: werkend, werkzoekend, niet werkend. Na een periode van initiële scholing volgt een toetreding tot de arbeidsmarkt. In verband met zorgtaken kan na verloop van tijd (gedeeltelijke) uittreding uit het arbeidsproces plaatsvinden, eventueel na enige tijd weer gevolgd door herintreding. Veroudering leidt aan het einde van de loopbaan tot een terugtrekking van de arbeidsmarkt en pensionering. Gedurende de loopbaan kunnen verder veranderingen van arbeidsmarktstatus plaatsvinden door werkloosheid of door arbeidsongeschiktheid. Ook deze veranderingen kunnen gerelateerd zijn aan de levensloop: veroudering en arbeidsongeschiktheid bijvoorbeeld gaan vaak samen. Ten slotte vinden overgangen plaats tussen de werknemerstatus en die van zelfstandige; werknemers kunnen na het opdoen van ervaring voor het zelfstandige ondernemerschap kiezen.

De individuele wisselingen van de ene arbeidsmarktstatus naar de andere die in een bepaalde periode plaatsvinden, tellen op tot stromen op de arbeidsmarkt. De omvang van die stromen is medebepalend voor de externe flexibiliteit van de Nederlandse arbeidsmarkt. Deze stromen zullen in beeld worden gebracht. Het cijfermateriaal dat wij vooral gebruiken in dit hoofdstuk, bestaat uit individuele gegevens van alle ingezetenen van Nederland die over een aantal perioden in het Sociaal Statistisch Bestand (SSB) van het Centraal Bureau voor de Statistiek bijeen zijn gebracht. 
In het stromenmodel van de transitionele arbeidsmarkt worden arbeidsmarktstatussen onderscheiden waarin mensen zich op enig moment kunnen bevinden: huishouden, scholing, werkloosheid, pensionering en arbeid. In deze paragraaf concentreren we ons op de stromen van baan naar baan, van baan naar werkloosheid, van werkloosheid naar baan en de stromen in en uit de beroepsbevolking. Deze stromen zijn in figuur 3.1 weergegeven.

\section{Figuur 3.1 Stromen op de transitionele arbeidsmarkt}

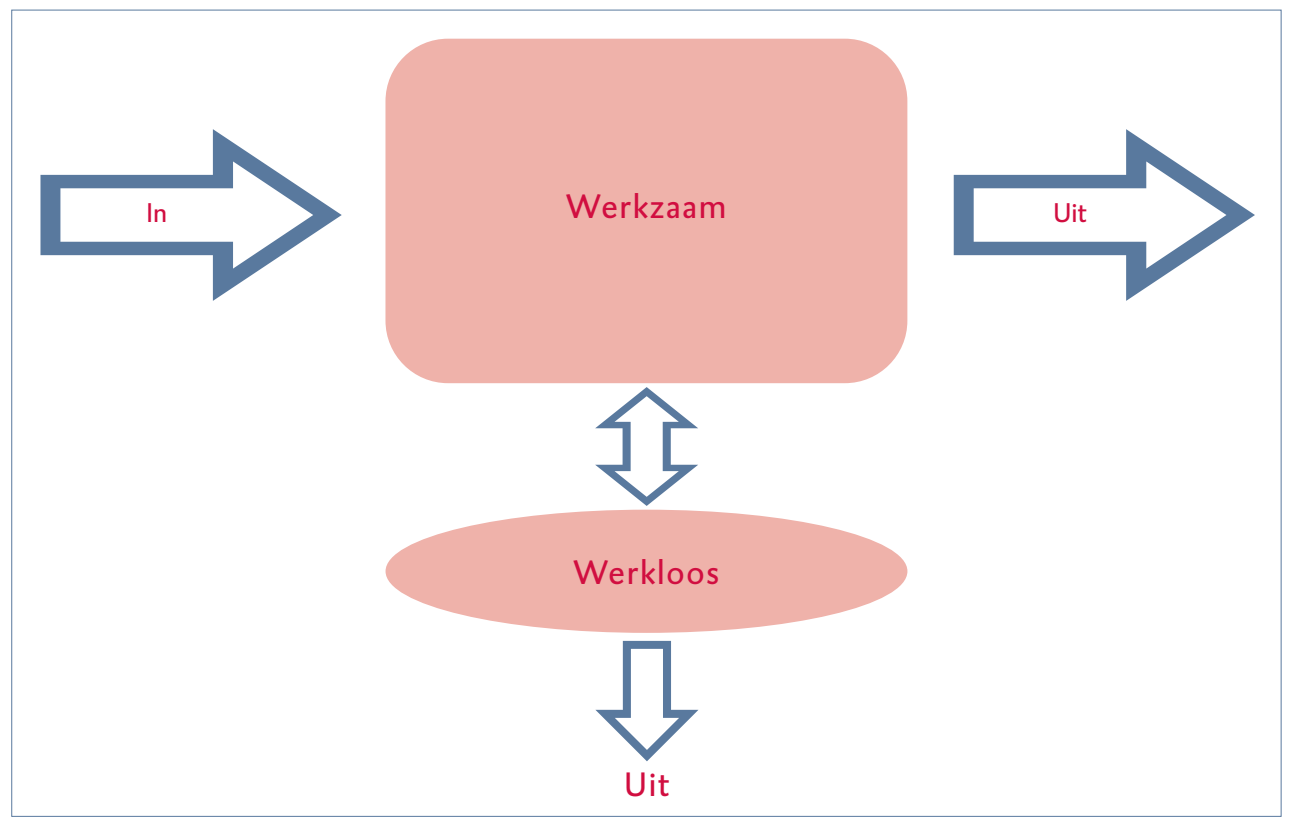

In de transitionele arbeidsmarktbenadering wordt de aandacht erop gevestigd dat de traditionele door de levensloop bepaalde patronen waarlangs transities op de arbeidsmarkt plaatsvinden, geleidelijk doorbroken worden. Levenslopen worden meer heterogeen. Het verlaten van het mannelijke kostwinnersmodel, een grotere heterogeniteit van het arbeidsaanbod en uiteenlopende preferenties leiden ertoe dat de mobiliteit minder strikt langs de geijkte paden verloopt.

Het is van belang te constateren dat vanaf de jaren negentig zich een demografische ommezwaai op de arbeidsmarkt voltrekt. De instroom van jongeren en schoolverlaters wordt relatief kleiner. Vrouwen zijn in relatief sterke mate toegetreden in de jaren negentig en het is steeds minder gebruikelijk om bij de geboorte van kinderen weer uit te treden. Er vindt een uitstroom van omvangrijke cohorten van oudere werknemers plaats. Deze uitstroom wordt enigszins gematigd door de geleidelijke toename van de participatiegraden van oudere werknemers. Een combinatie van relatieve afname in de instroom op de arbeidsmarkt van jongeren, schoolverlaters en vrouwen en een relatieve 
toename van de uitstroom van de oudere werknemers moet uiteindelijk leiden tot een afname van de nettogroei van het arbeidsaanbod. Het is de verwachting dat de groei van het arbeidsaanbod afvlakt. Indien de vraag naar arbeid onveranderd blijft groeien, ontstaat in de nabije toekomst een krappe arbeidsmarkt (CPB 2006).

\subsubsection{ARBEIDSMARKTSTROMEN EN LANGDURIGE EN HERHALINGS- WERKLOOSHEID}

In tabel 3.1 is weergegeven hoe personen in de periode oktober 2002-oktober 2003 veranderden van arbeidsmarktstatus. De tabel laat zien dat van de 6.547.0oo personen die eind september 2002 een baan hadden, 5.999.00o eind september 2003 ook een baan hadden, 86 .0oo werkloos waren, 39.000 als zelfstandige werkzaam waren en 423.000 uit de beroepsbevolking waren gestroomd. Ook laat de tabel zien dat er van de 631.000 zelfstandigen in de loop van het jaar 33.000 ingestroomd waren als werknemer, 555.000 in 2003 nog steeds als zelfstandige werkzaam waren en 42 .ooo uit de beroepsbevolking waren gestroomd. Vergelijkbare stromen staan in de andere rijen en kolommen. Op de diagonaal staat het aantal mensen dat op beide meetmomenten dezelfde status had.

Tabel 3.1 Stromen op de arbeidsmarkt, relatief (2002-2003)

\begin{tabular}{|l|r|r|r|r|r|} 
Van / naar & In 2002 & Werknemer & WW & $\begin{array}{r}\text { Zelfstandig } \\
\text { In 2003 }\end{array}$ & $\begin{array}{r}\text { Niet beroeps- } \\
\text { bevolking }\end{array}$ \\
Werknemer & & \multicolumn{4}{|c|}{ In } \\
WW & 6.546 .830 & 5.998 .550 & 85.870 & 38.980 & 423.430 \\
Zelfstandig & 116.750 & 26.300 & 61.150 & 2.330 & 26.970 \\
Niet beroepsbevolking & 9.557 .130 & 33.460 & 850 & 555.390 & 41.750 \\
Totaal in 2003 & & 439.350 & 27.420 & 27.620 & 9.062 .740 \\
& & 6.497 .660 & 175.290 & 624.320 & 9.554 .890 \\
\hline
\end{tabular}

Bron: CBS SSB

Opvallend is dat iets meer dan de helft van de mensen die eind september 2002 werkloos waren dat een jaar later nog steeds (of opnieuw) was; in het eerste geval is er sprake van langdurige werkloosheid, in het laatste van herhalingswerkloosheid. Slechts een kwart van de werklozen is in de betrokken periode uitgestroomd als werknemer of als zelfstandige; het laatste kwart is in een andere uitkeringssituatie terechtgekomen. De langdurige werkloosheid in Nederland is in de afgelopen periode sterk teruggelopen (Belot en Van Ours 2007). Ook uit andere bronnen blijkt dat een van de opmerkelijke resultaten van de hoogconjunctuur van de jaren negentig was dat de arbeidsmarkt zo gunstig uitpakte dat langdurige werkloosheid terugliep of in elk geval niet of nauwelijks werd aangevuld met nieuwe instroom. Wat we in tabel 3.1 zien is dus vermoedelijk herha- 
lingswerkloosheid, dezelfde mensen zijn werkloos in oktober 2002 en opnieuw in oktober 2003.

Het relatieve belang van herhalingswerkloosheid wordt bevestigd door een studie van De Koning, Kroes en Van der Steen (2006). In deze studie is gebruikgemaakt van individuele belastinggegevens van burgers over een periode van 12 jaar (1989-2000) om het gebruik dat mensen maken van uitkeringen boven tafel te krijgen. Een belangrijke conclusie uit deze studie is: "Van de gehele bevolking heeft 17 procent een ww-uitkering gehad. De overgrote meerderheid van de bevolking heeft geen beroep hoeven te doen op de ww. Ook binnen de groep van uitkeringsgerechtigden is het gebruik van de ww niet gelijk verdeeld. Het deciel (tien procent) van de mensen met het hoogste wW-beslag neemt 36 procent van het beslag in tijd en 47 procent van het beslag in inkomen voor hun rekening." Met andere woorden: de meeste werknemers maken tijdens hun loopbaan nooit gebruik van de werkloosheidsvoorziening. Werkloosheid is heel sterk geconcentreerd bij een relatief kleine groep werknemers. Tien procent van de kleine groep verklaart bijna de helft van alle ww-uitkeringen.

\section{$3 \cdot 3$ BAANWISSELINGEN}

Baanwisselingen hebben deels te maken met het verdwijnen van banen en deels met nieuwe kansen door het ontstaan of het vrijkomen van banen. Daarnaast is er een voortdurende in- en uitstroom op de arbeidsmarkt die ook kansen biedt voor doorstroom.

\subsubsection{BAANCREATIE EN BAANDESTRUCTIE}

De processen die leiden tot groei en krimp van bedrijven noemen we samen 'creatieve destructie'. Dat gebeurt onder invloed van externe ontwikkelingen zoals technologische en organisatorische veranderingen; het gebeurt ook onder invloed van de concurrentie, binnenlandse of internationale. Er vindt als gevolg van de creatieve destructie een niet ophoudende herschikking van werknemers van de ene baan naar de andere plaats (baanwisselingen). Werknemers stromen verder in en uit de werkloosheid en op en af de arbeidsmarkt (arbeidsmarktstatuswisselingen). Bij grote bedrijven en conglomeraten speelt creatie en destructie ook intern binnen het bedrijf. Bij kleinere bedrijven vinden de herschikkingen eerder via de externe arbeidsmarkt plaats.

In de internationale literatuur wordt in navolging van Davis, Haltiwanger en Schuh (1998) creatie van banen gedefinieerd als de som van de nettobanengroei in de groeiende bedrijven plus de baancreatie van nieuw opgerichte bedrijven. Destructie van banen wordt gedefinieerd als de som van de (netto)banendestructie bij krimpende bedrijven plus het verlies van banen bij opgeheven bedrijven. De baanmutaties zijn gedefinieerd op bedrijfsniveau, wat impliceert dat de aantallen een ondergrens zijn van de werkelijke baanmobiliteit. In figuur 3.2 brengen we aldus de procentuele baancreatie en destructie in beeld. 
Figuur 3.2 Creatie en destructie van banen 1999-2003

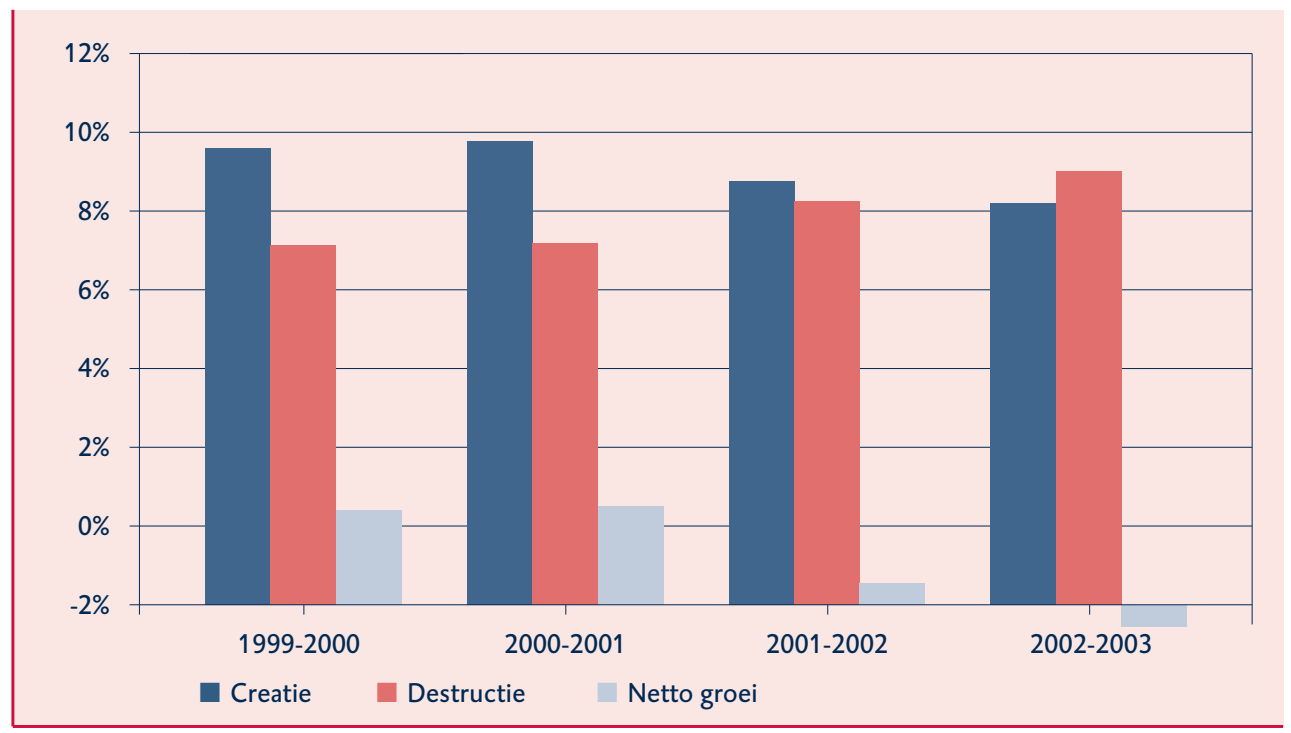

Bron: CBS SSB

Creatie en destructie van banen worden gemeten door het aantal banen in een bedrijf op een dag in een bepaald jaar te vergelijken met het aantal banen op dezelfde dag een jaar later. Het aanzetten van de recessie aan het begin van deze eeuw is duidelijk te zien in deze data; de creatie van banen neemt af en de destructie neemt toe. Het verschil tussen creatie en destructie is de netto groei (de 'derde' staaf in figuur 3.2). In de twee eerste perioden van hoogconjunctuur (1999-2000 en 2000-2001) stijgt de creatie boven de destructie uit (ruwweg 9 procent versus 7 procent) en is de nettogroei 2,4 procent. In de derde periode, 2001-2002 is de recessie in aantocht en is het verschil tussen creatie en destructie nog altijd positief, maar het verschil (de nettogroei) is slechts 0,4 procent.

In de periode 2002-2003 zitten we in een laagconjunctuur; er worden meer banen vernietigd dan gecreëerd en netto daalt het aantal banen met -o,7 procent. Duidelijk is dat er zowel in de hoog en de laagconjunctuur creatie en destructie van banen plaatsvindt. De creatieve destructie houdt nooit op. Wat met de conjunctuur verandert, is het verschil tussen creatie en destructie. Naarmate recessie dichterbij komt stijgt de destructie van banen en daalt de creatie. De creatie is door de tijd heen gemiddeld 9 procent van het totale aantal banen, destructie is gemiddeld 8 procent. Gemiddeld 17 procent van de banen (de som van creatie en destructie) verandert in de loop van een jaar.

We onderscheiden voor bedrijven vijf verschillende situaties wat betreft de nettoverandering in werkgelegenheid van het ene jaar op het andere. Bedrijven waar de werkgelegenheid netto toeneemt zijn groeiende bedrijven. Bedrijven met een nettoafname van de werkgelegenheid zijn krimpende bedrijven. Bij neutrale bedrijven verandert de totale werkgelegenheid van het ene jaar op het 
andere niet. Nieuwe bedrijven zijn er in de loop van het jaar bijgekomen en hebben alleen maar nieuwe banen gecreëerd. Opgeheven bedrijven zijn in de loop van het jaar verdwenen; zij hebben enkel banen vernietigd. In tabel 3.2 is voor deze bedrijfssituaties de creatie en de destructie van banen weergegeven volgens de definitie van Davis, Haltiwanger en Schuh (1998). De baancreatie en de baandestructie in neutrale bedrijven zijn per definitie gelijk aan nul.

Tabel 3.2 Baancreatie en baandestructie naar groeicategorie (2002-2003)

\begin{tabular}{|l|r|r|} 
& Baancreatie & Baandestructie \\
Nieuwe bedrijven & 178.780 & 0 \\
Groeiende bedrijven & 404.310 & 0 \\
Neutrale bedrijven & 0 & 0 \\
Krimpende bedrijven & 0 & 533.250 \\
Opgeheven bedrijven & 0 & 103.120 \\
\hline
\end{tabular}

Bron: CBS SSB

Zowel de creatie als de destructie van banen gaat gepaard met het gelijktijdig komen en gaan van werknemers. Groeiende bedrijven trekken niet alleen mensen aan, ze stoten ook mensen af. Krimpende bedrijven nemen in de loop van het jaar nog nieuwe mensen aan, terwijl ze tegelijk mensen afstoten en kwijt raken. Creatie en destructie vinden voor het overgrote deel plaats bij bestaande bedrijven (die groeien of krimpen). Opstartende bedrijven zijn goed voor ruim een kwart van het totaal aantal gecreëerde banen en failliete bedrijven veroorzaken ruim 15 procent van het totaal aantal vernietigde banen.

\subsubsection{ONVRIJWILLIGE MOBILITEIT}

Baandestructie betekent dat werknemers hun baan verliezen. Als zij een andere baan vinden noemen wij dit een onvrijwillige baanwisseling, immers deze is onder druk van de omstandigheden tot stand gekomen. De andere mogelijkheid is dat werknemers geen baan vinden of daar ook niet naar op zoek gaan. Het is interessant om te zien waar de werknemers die vertrekken vanuit een vernietigde baan naartoe gaan. Exacte gegevens hebben we daar niet over. We kunnen het saldo van vertrekkende en binnenkomende baanwisselaars bij krimpende en opgeheven bedrijven als een indicatie zien van de stroom van werknemers die vanuit een vernietigde baan naar een andere baan gaan. En we kunnen het saldo van binnenkomende werknemers van buiten de arbeidsmarkt en vertrekkende werknemers naar buiten de arbeidsmarkt als een indicatie zien van de stroom van werknemers die vanuit een vernietigde baan buiten de arbeidsmarkt raken. In figuur 3.3 laten we dat zien voor het hoogconjunctuurjaar 1999-200o en voor het laagconjunctuurjaar 2002-2003. 
Figuur 3.3 Bestemming vanuit een vernietigde baan

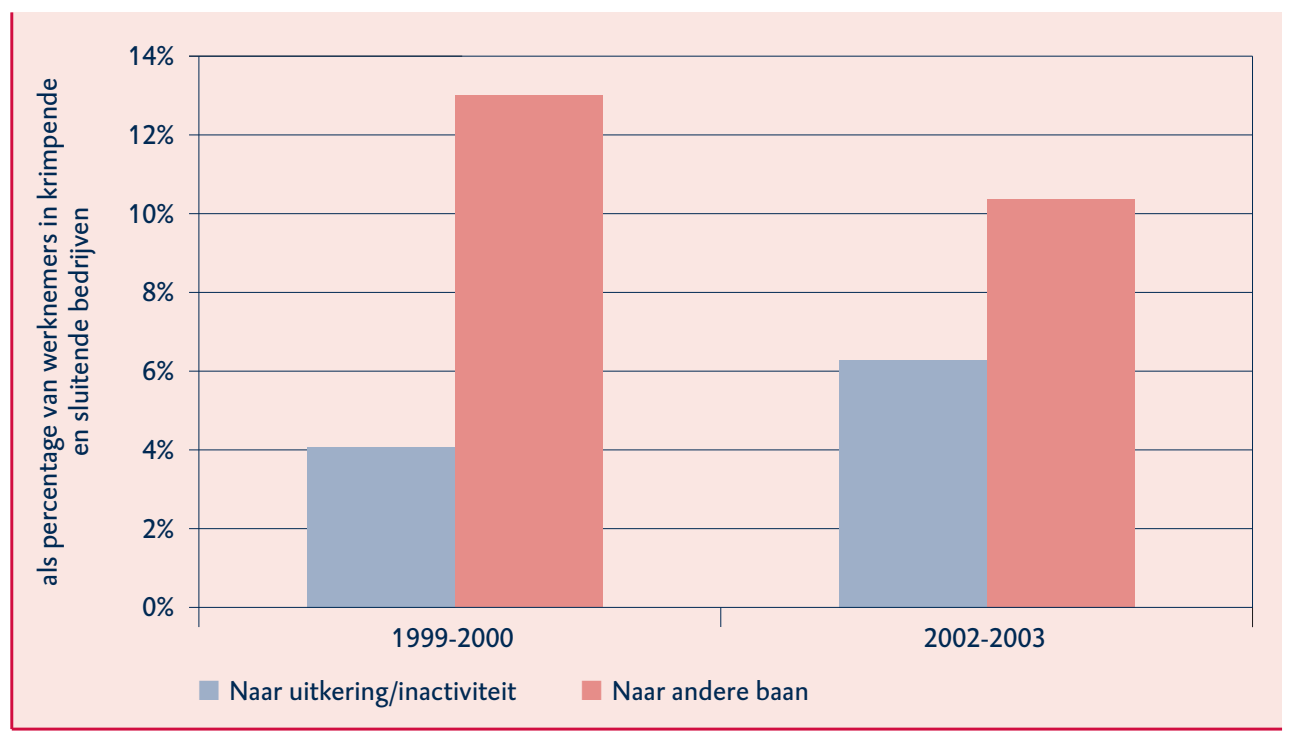

Bron: CBS SSB

Het is conform de verwachting dat er in een periode van hoogconjunctuur meer personen waarvan de baan vernietigd is, van baan naar baan gaan dan in een periode van laagconjunctuur. Tegelijkertijd verdwijnen er in een periode van hoogconjunctuur minder personen van wie de baan vernietigd is naar een uitkering of inactiviteit. De stroom naar buiten de arbeidsmarkt is divers samengesteld. Werknemers en zelfstandigen stromen uit naar werkloosheid en naar statussen buiten de beroepsbevolking, waarbij het kan gaan om pensionering, om arbeidsongeschiktheid, om het volgen van onderwijs en een terugtrekking uit de arbeidsmarkt voor bijvoorbeeld zorgtaken. Uit tabel 3.1 bleek dat van 2002 op 200386 duizend personen van de status werkzaam naar de status werkloos zijn doorgestroomd. Dat is 1,2 procent van het totaal aantal werkzame personen in 2002 en 2,7 procent van het aantal werkzame personen in krimpende en sluitende bedrijven.

De vernietiging van banen is voor werknemers een belangrijke oorzaak van neerwaartse mobiliteit, dat wil zeggen instroom in werkloosheid of via inkomensachteruitgang de neerwaartse mobiliteit in. Inkomensvooruitgang of -achteruitgang is voor baanwisselaars sterk verbonden met de fase van de loopbaan waarin zij zich bevinden. Baanwisseling kan in elke fase van de loopbaan zowel vooruitgang als achteruitgang opleveren. Vanaf halverwege de loopbaan leveren baanwisselingen voor werknemers echter overwegend inkomensachteruitgang op. Aan het begin van de loopbaan is er overwegend inkomensvooruitgang bij baanwisseling. Het is te danken aan het feit dat baanwisselingen hoofdzakelijk aan het begin van de loopbaan plaatsvinden dat baanwisseling per saldo voor de meeste werknemers een inkomensvooruitgang oplevert. In hoofdstuk 5 zal hierop verder worden ingegaan. 
Over de inkomensontwikkeling van gedwongen baanwisselaars is geen specifieke informatie beschikbaar. Wel kan de inkomensontwikkeling bij een bepaalde baanduur worden onderscheiden voor baanwisselaars en voor blijvers. In tabel 3.3 is eerst voor baanwisselaars en daarna voor blijvers aangegeven in hoeverre werknemers van 2002 op 2003 een inkomensachteruitgang (negatief), een gelijk inkomen (neutraal) of een inkomensvooruitgang (positief) meemaakten. De rijen tellen op tot 100 procent. In de eerste kolom staat aangegeven hoe lang de werknemer in 2002 al bij zijn huidige werkgever werkte. In de tweede kolom staat dit aangegeven voor 2003. Als de baanduur in 2003 korter is dan in 2002 is er logischerwijs sprake van een baanwisseling.

Tabel 3.3 Richting van de inkomensontwikkeling naar baanduur (percentages)

\begin{tabular}{|c|c|c|c|c|}
\hline $\begin{array}{l}\text { Baanduur } \\
2002\end{array}$ & 2003 & $\begin{array}{l}\text { Negatief } \\
\text { Baanwisselaars }\end{array}$ & Neutraal & Positief \\
\hline$>10$ jaar & $<1$ jaar & 63,9 & 8,1 & 28,0 \\
\hline $3-10$ jaar & $<1$ jaar & 49,9 & 5,9 & 44,1 \\
\hline \multirow[t]{2}{*}{$<3$ jaar } & $<1$ jaar & 39,0 & 5,1 & 55,9 \\
\hline & & Blijvers & & \\
\hline$<3$ jaar & $<3$ jaar & 22,1 & 12,8 & 65,1 \\
\hline$<3$ jaar & $3-10$ jaar & 29,4 & 16,6 & 54,0 \\
\hline $3-10$ jaar & $3-10$ jaar & 32,6 & 19,5 & 47,9 \\
\hline $3-10$ jaar & $>10$ jaar & 34,0 & 22,0 & 43,9 \\
\hline$>10$ jaar & $>10$ jaar & 35,8 & 25,0 & 39,3 \\
\hline
\end{tabular}

Bron: CBS SSB

Het is opvallend dat baanwisselingen van werknemers die al lang op een baan zitten, in zeer overwegende mate een negatieve inkomensontwikkeling betekenen. Blijvers die nog maar kort op een baan zitten maken echter grote kans op een inkomensvooruitgang. De kans op een positieve inkomensontwikkeling neemt af naarmate men langer op een baan zit. Een negatieve inkomensontwikkeling kan overigens ook vrije keuze zijn, bijvoorbeeld als werknemers zelf besluiten om minder te gaan werken.

\subsubsection{VRIJWILLIGE MOBILITEIT}

\section{Conjunctuur en mobiliteit}

Per jaar wisselen gemiddeld circa 1 miljoen werknemers van baan. In tabel 3.4 wordt aangegeven hoeveel mensen jaarlijks van baan wisselen. Zoals blijkt uit deze tabel ligt dat percentage in de periode 1999-2003. tussen de 12 en de 16 procent. In een conjunctureel goed jaar (bijv. 1999-2000) is het aantal baanwisselaars 
relatief hoog (16 procent); in een conjunctureel minder goed jaar (bijv. 20022003) zakt het naar 12 procent (nog altijd 1 op de 8 werknemers). In een conjunctureel goed jaar zijn er relatief veel vacatures waardoor er voor werknemers meer mogelijkheden zijn voor een nieuwe baan die aantrekkelijker is (of lijkt) dan de huidige baan. Met relatief veel vacatures gaan werkgevers ook op zoek naar nieuwe werknemers die ze soms van andere bedrijven losweken. In een conjunctureel minder goed jaar zijn er veel minder mogelijkheden om zich via een nieuwe baan te verbeteren en dan zakt het aantal baanwisselaars ook in.

Tabel 3.4 Baanwisselaars in de periode 1999-2003

\begin{tabular}{|l|c|c|c|} 
Periode & $\begin{array}{c}\text { Banen } \\
(\mathbf{x} 1.000)\end{array}$ & $\begin{array}{c}\text { Baanwisselaars } \\
(\mathbf{x ~ 1 . 0 0 0 )}\end{array}$ & $\begin{array}{c}\text { Baanwisselaars } \\
\text { percentage }\end{array}$ \\
$1999-00$ & 7.282 & 1.129 & $16 \%$ \\
$2000-01$ & 7.456 & 1.118 & $15 \%$ \\
$2001-02$ & 7.631 & 1.045 & $14 \%$ \\
$2002-03$ & 7.660 & 885 & $12 \%$ \\
\hline
\end{tabular}

Bron: CBS SSB

Dat ook het totale aantal baanwisselaars met de conjunctuur meebeweegt (hoog in hoogconjunctuur en laag in laagconjunctuur) geeft ook al aan dat de baanwisseling meestal vrijwillig is. Stel dat baanwisseling meestal onvrijwillig en gedwongen was, dan zou het patroon eerder tegen de cyclus ingaan: veel baan-

Figuur 3.4 Cyclisch patroon percentage baanwisselaars

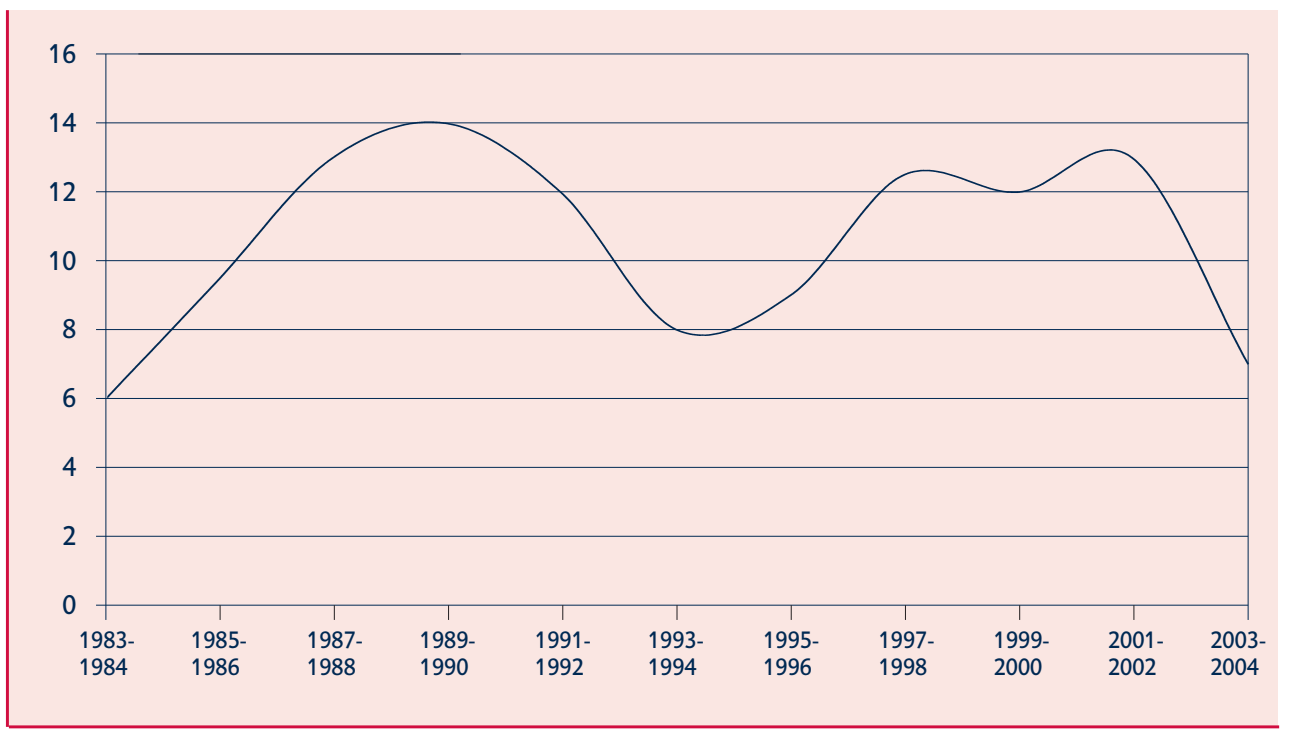

Bron: OSA (Arbeidsaanbodpanel 1988-2004) 
wisseling in slechte conjuncturele tijden en weinig in conjunctureel goede tijden. In figuur 3.4 is het percentage baanwisselingen over een langere periode weergegeven en komt het procyclische verband met de conjunctuur nog duidelijker tot uitdrukking.

Het conjuncturele patroon van de baanwisseling is zeer duidelijk. De Nederlandse economie bevond zich in een conjunctureel gunstige situatie aan het eind van de jaren tachtig, begin jaren negentig. In de eerste helft van de jaren negentig zakte de conjunctuur in. Vanaf 1995-1996 begon een van de langste naoorlogse conjuncturele groeiperiodes, die in de eerste jaren van dit decennium weer inzakte. Het percentage baanwisselaars sluit naadloos aan bij deze conjunctuurgolf. Opmerkelijk is dat de externe mobiliteit over de beschouwde periode niet structureel is toegenomen.

\section{Vrijwillige mobiliteit}

Mobiliteit betreft niet alleen de gedwongen mobiliteit. Het grootste gedeelte van de baanwisselingen is vrijwillig (SCP 2005). In figuur 3.5 is de ontwikkeling in de verhouding tussen vrijwillige en gedwongen mobiliteit weergegeven. Het is opvallend, maar niet verrassend dat die verhouding sterk door de conjunctuur beïnvloed wordt.

Vrijwillige mobiliteit in het algemeen is mogelijk door het bestaan van vacatures. Die ontstaan door het vertrek van werknemers of door het creëren van nieuwe banen. Door het vertrek van werknemers van de arbeidsmarkt is er een continue doorstroom. Een niet onbelangrijke reden voor het vertrek van de arbeidsmarkt is

\section{Figuur 3.5 Vrijwillige en gedwongen mobiliteit van werknemers}

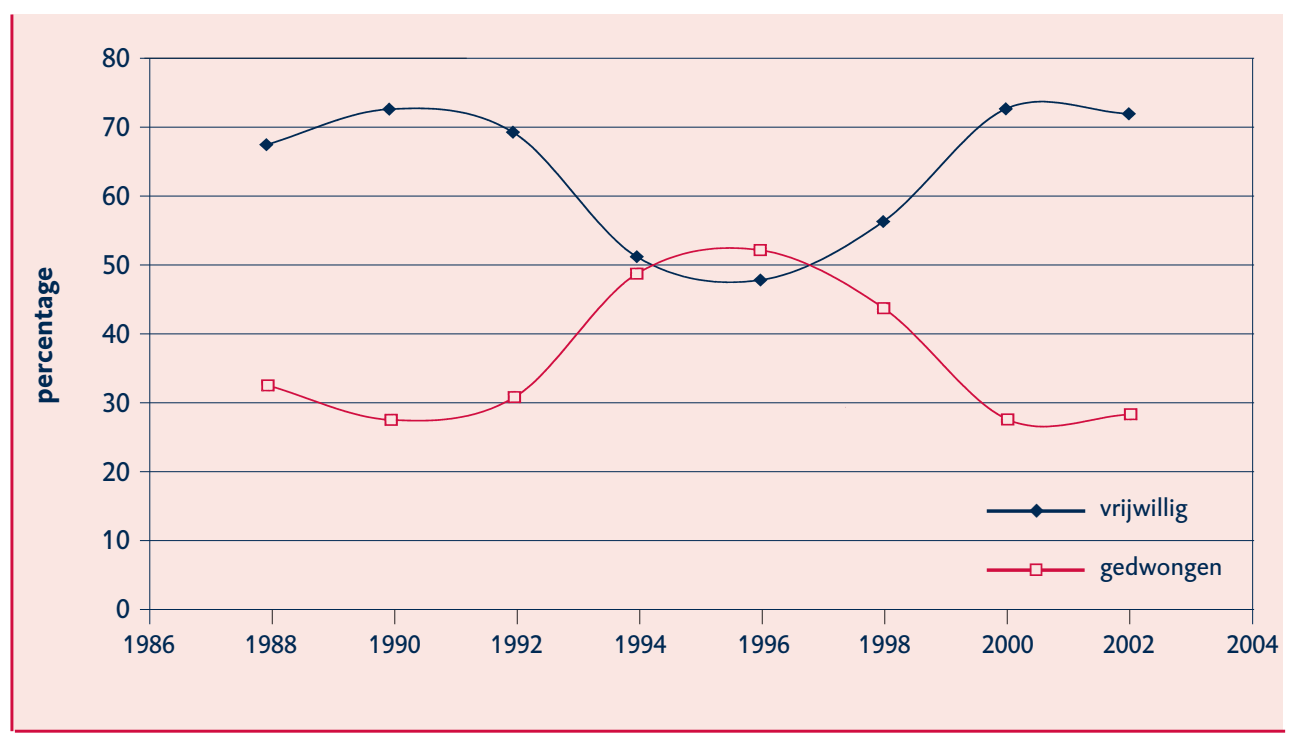

Bron: SCP (2005) 
pensionering. Het vertrek van oudere werknemers van de arbeidsmarkt biedt ruimte voor jongere werknemers om de arbeidsmarkt te betreden. In de regel nemen jongere werknemers niet een op een de arbeidsplaats van oudere werknemers in. Door het ontstaan van een aantrekkelijke vacature kan een hele keten van baanwisselingen op gang gebracht worden. Nieuwkomers op de arbeidsmarkt nemen de plek in van werknemers die kans gezien hebben om opwaartse mobiliteit te realiseren door van baan te wisselen.

\section{Bezetting van nieuwe banen}

Vacatures ontstaan ook doordat banen gecreëerd worden. De vorige subparagraaf begonnen we met de vraag waar werknemers van vernietigde banen terechtkomen. Deze subparagraaf wordt beëindigd met de vraag waar werknemers die nieuw geschapen banen bezetten vandaan komen, vanuit een andere baan of van buiten de arbeidsmarkt. In figuur 3.6 is de herkomst van werknemers op gecreëerde banen weergegeven als percentage van het totaal aantal werknemers in nieuwe bedrijven en in groeiende bedrijven.

\section{Figuur 3.6 Herkomst voor een gecreëerde baan}

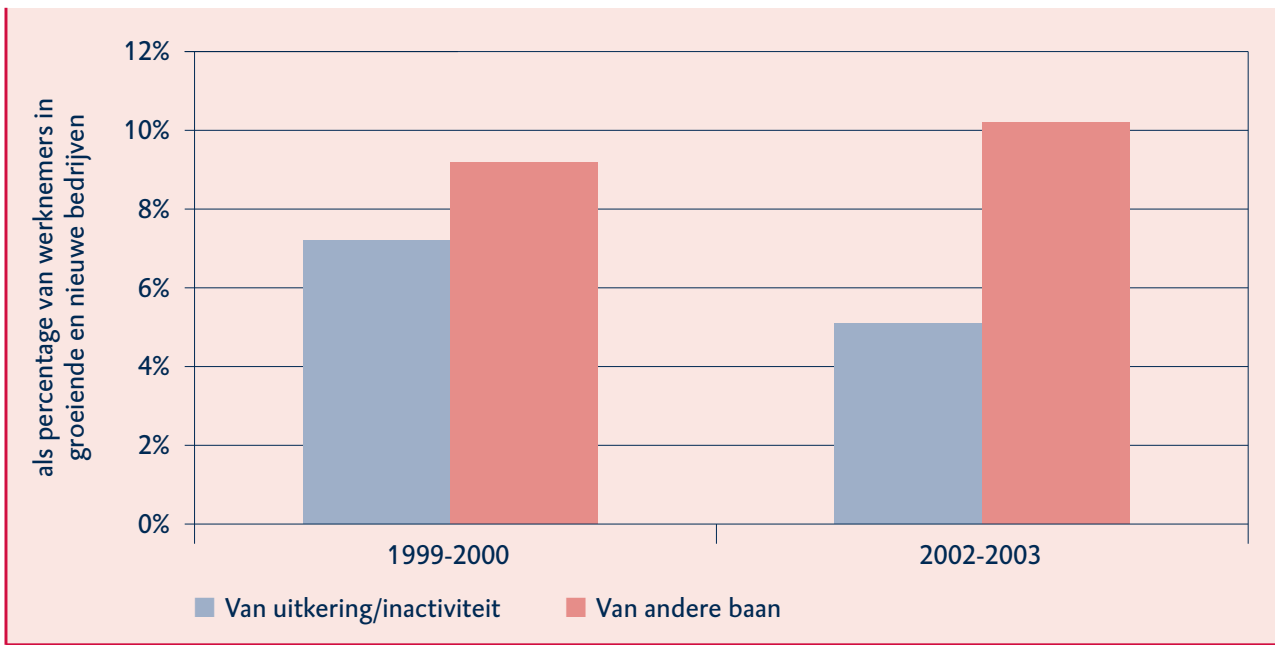

Bron: CBS SSB

Een nieuw gecreëerde baan kan bezet worden door iemand die uit een uitkering of de inactiviteit komt, of door iemand die uit een andere baan komt. Wat figuur 3.6 duidelijk maakt is dat de mobiliteit naar en uit een andere baan altijd belangrijker is dan de mobiliteit in en uit een uitkering of inactiviteit. Het grootste deel van de re-allocatie ten gevolge van baancreatie gebeurt door direct van de ene naar de andere baan over te stappen en minder via de route van de uitkering en de inactiviteit. In de hoogconjunctuurperiode (1999-2000) blijken er meer mogelijkheden te zijn om van buiten de arbeidsmarkt een baan te vinden, en ook voor mobiliteit van en naar een andere baan zijn er meer mogelijkheden; in een laagconjunctuur wordt het wisselen van baan flink afgeremd. 


\subsection{EXTERNE FLEXIBILITEIT EN PRODUCTIVITEIT}

Creatieve destructie en externe mobiliteit hebben effect op de groei van de productiviteit. Productieve bedrijven groeien en minder productieve bedrijven krimpen. Werknemers zijn aan het begin van hun loopbaan op zoek naar de baan die het beste bij hen past en verhogen daardoor hun productiviteit. Externe mobiliteit en bedrijfsinvesteringen in human capital met het oog op productiviteitsverbetering hangen met elkaar samen. En de productiviteitsontwikkeling wordt ten slotte belemmerd wanneer werknemers op een punt in hun loopbaan vastlopen.

\subsubsection{CREATIEVE DESTRUCTIE ALS BRON VAN PRODUCTIVITEITSSTIJGING}

De instroom in bedrijven is groter dan alleen het percentage baanwisselaars suggereert. Hier moet immers ook de instroom op de arbeidsmarkt bij opgeteld worden. Voor de uitstroom uit bedrijven geldt eenzelfde verhaal. In figuur $3.7 \mathrm{zijn}$ beide stromen voor ingaande werknemers en uitgaande werknemers bij elkaar opgeteld.

Figuur 3.7 Inkomende en uitgaande stroom van werknemers

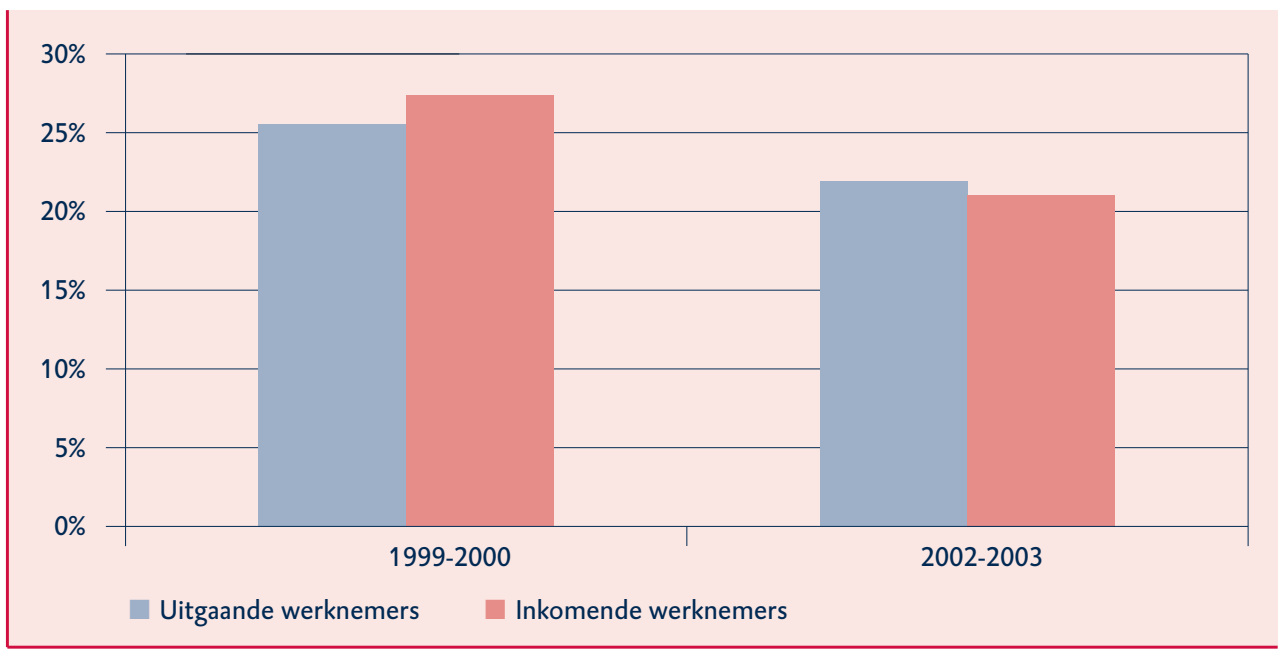

Bron: CBS SSB

Voor elk van de perioden liggen de inkomende en de uitgaande stroom jaarlijks tussen 20 en 25 procent van alle werkzame personen. Dat is een vrij grote mobiliteit van personen. Vergelijk dit met de omvang van de creatie en destructie van banen in figuur 3.2 hierboven. Ongeveer 8 procent van de banen wordt jaarlijks vernietigd, en circa 9 procent komt er aan nieuwe banen bij. Deze creatie en destructie van banen veroorzaken een herschikking van werknemers die tweetot driemaal zo groot is. Voor elke baan die er bijkomt of verdwijnt verwisselen twee tot drie personen van positie. De verklaring dat de werknemersflexibiliteit 
groter is dan de banenflexibiliteit is te vinden bij het keteneffect dat door creatie en destructie wordt veroorzaakt.

Herschikking van arbeid draagt in relatie tot het verdwijnen en het scheppen van banen onder voorwaarden bij aan de welvaart van de samenleving. Een voorwaarde is dat verdwenen banen minder productief zijn dan geschapen banen. Het kan zijn dat een werknemer die van een verdwenen baan komt een hogere productiviteit heeft op een geschapen baan. Het kan ook zijn dat een andere werknemer de geschapen baan gaat bezetten, terwijl de werknemer die van de verdwenen baan komt een baan met een geringere productiviteit gaat bezetten. Per saldo kan er dan nog sprake zijn van welvaartswinst. Er is dan alleen een situatie waarin er zowel winnaars als verliezers zijn. Herschikking van arbeid kan ook aan de welvaart bijdragen zonder dat er banen verdwijnen of worden geschapen. Instroom en uitstroom op de arbeidsmarkt kunnen ertoe leiden dat beter opgeleide werknemers de arbeidsplaatsen van minder opgeleide en minder productieve werknemers innemen.

'Productiviteit' moet ruim worden geïnterpreteerd. Meer productiviteit betekent niet alleen dat een baanwisselaar per uur meer produceert op de nieuwe baan dan op de oude, maar kan ook betekenen dat hij op de nieuwe baan werkt aan de productie van producten waaraan de samenleving een grotere behoefte heeft. Op die manier draagt baanwisseling bij aan de toename van de welvaart, de economische groei en de groei van de arbeidsproductiviteit. Van een betere herschikking profiteren zowel de werknemer (die krijgt een baan die beter bij hem of haar past), de werkgever (die krijgt een werknemer die beter bij het bedrijf past) als de samenleving (die krijgt een productievere allocatie van de factor arbeid).

In een laagconjunctuur gaan relatief veel bedrijven failliet en verdwijnen er arbeidsplaatsen, in een hoogconjunctuur worden nieuwe bedrijven opgericht en scheppen bestaande bedrijven nieuwe arbeidsplaatsen. Het werkloosheidsniveau is hoog in de laagconjunctuur en laag in de hoogconjunctuur. Verschillende groepen op de arbeidsmarkt hebben andere werkloosheidservaringen. Sommige groepen (laaggeschoolden, jongeren) hebben door de cyclus heen meer kans op werkloosheid dan andere groepen. In de werkloosheid en ook in het feit dat mensen noodgedwongen op minder productieve banen terechtkomen zitten de negatieve aspecten van de creatieve destructie (van fabrieksarbeider naar hamburgerflipper).

Recent empirisch onderzoek naar productiviteitsontwikkelingen op het niveau van individuele bedrijven onderstreept dat de re-allocatie van middelen (waaronder arbeid) van minder productieve naar meer productieve bedrijfsactiviteiten een significante en kwantitatief belangrijke bijdrage levert aan de groei van de arbeidsproductiviteit in een land. In de verbetering van de arbeidsproductiviteit schuilen de baten van het proces van baanvernietiging en baanschepping. Bartelsman en Doms (200o) stellen dat over een periode van tien jaar in de Verenigde Staten een kwart van de groei (total factor productivity) voor rekening komt van 
sluitende en opgerichte bedrijven, de helft van de groei voor rekening van factoren binnen bedrijven zelf en de rest van de groei voor rekening van herschikkingen in het marktaandeel en de omvang van groeiende en krimpende bedrijven. Dit neemt niet weg dat er in het proces van creatieve destructie winnaars en verliezers zijn.

Tijdens een hoogconjunctuur, wanneer de vraag naar arbeid groter is dan het aanbod van arbeid, kan een krappe arbeidsmarkt ontstaan waarin werkgevers zitten te springen om werknemers. Zij gaan die vervolgens wegkopen bij andere werknemers. Op de top van een hoogconjunctuur kan er letterlijk een tekort aan werknemers ontstaan (denk aan lang openstaande onvervulbare vacatures). Mobiliteit wordt dan een zero-sum game voor de samenleving, er komt geen extra productiviteit bij. De oververhitte arbeidsmarkt kent alleen maar looninflatie.

\subsubsection{INFORMATIEPROBLEMEN EN PRODUCTIVITEIT}

Het is voor de baanwisselaar van tevoren moeilijk te zeggen of een baan zal bevallen. Hij beschikt bij het aanvaarden van een nieuwe baan over relatief weinig informatie over de baan en de werkomgeving. Ook de werkgever die een nieuwe medewerker in dienst neemt, gaat ervan uit dat het selectieproces goed is verlopen en dat de nieuwe werknemer zal bevallen. Maar of de baan echt bevalt en of de nieuwe werknemer inderdaad een succes is, kan alleen uit ervaring blijken. Een aantal baanwisselingen blijkt achteraf geen succes. Na verloop van tijd kunnen werkgever en werknemer besluiten om weer uit elkaar te gaan. Het zoekproces begint dan opnieuw.

Een deel van de mobiliteit die we waarnemen op de arbeidsmarkt wordt gedreven door het gebrek aan informatie bij werkgevers en werknemers, door foute beslissingen en herstel daarvan. Aan het zoeken naar een geschikte baan door een werknemer zijn kosten en tijd verbonden. Aan het werven van een nieuwe werknemer door een werkgever zijn eveneens kosten en tijd verbonden. Een aantal baanwisselingen op de arbeidsmarkt is verspilde moeite en gaat dus niet de richting uit van hogere productiviteit en meer welvaart. Voor een deel zijn deze informatieproblemen niet op te lossen (een baan blijft een ervaringsgoed, volledige informatie komt pas na de baan te hebben ervaren), voor een deel kunnen de zoekprocessen worden verbeterd door het gebruik van zoekkanalen en door een hogere professionaliteit in werving en selectie.

Informatieproblemen kunnen zowel tot te veel als te weinig mobiliteit leiden. Te veel mobiliteit omdat een aantal baanwisseling dat heeft plaatsgevonden achteraf toch niet goed blijkt te zijn. De juiste man/vrouw is niet op de juiste plaats terechtgekomen. Verkeerde mobiliteit draagt niet bij aan de verhoging van de welvaart. Er kan ook te weinig mobiliteit zijn door de informatieproblemen. De kosten en moeite die door werknemers moeten worden gedaan om een betere baan te vinden (en door werkgevers om een betere werknemer te vinden) kunnen een belemmering zijn om van baan te wisselen. Deze kosten kunnen producti- 
viteits- en welvaartsverhogende transities afremmen, en ook kunnen zij werknemers in een monopsoniesituatie brengen.

Ook zijn er voor werkgevers kosten wanneer een werknemer weggaat en een andere daarvoor wordt aangetrokken. Het vertrek van de werknemer leidt tot verlies aan productie zolang de vacature blijft openstaan, terwijl het gemis van een ervaren kracht ook kan betekenen dat de productiviteit van blijvende werknemers minder wordt. Het kost ook tijd en geld om een nieuwe, capabele werknemer aan te trekken, bijvoorbeeld doordat een advertentie geplaatst moet worden en sollicitatiegesprekken gevoerd moeten worden. Vervolgens moet de nieuwe werknemer gedurende een bepaalde periode ingewerkt worden. In deze periode is de productiviteit laag.

Uit studies blijkt ook dat werkgevers veel zuiniger zijn in het loslaten van hun goed geschoolde werknemers dan hun minder goed geschoolde werknemers. Er wordt ook gesproken van arbeid als een quasi fixed factor. Het is niet zo dat werknemers arbeid laten meebewegen met de veranderingen in de productie.

\subsubsection{EXTERNE FLEXIBILITEIT EN DE OPBOUW VAN HUMAN CAPITAL}

Een hoge externe mobiliteit kan leiden tot onderinvesteringen in menselijk kapitaal. Wanneer een werkgever er niet zeker van is dat de werknemer voorlopig in dienst blijft, zal deze terughoudend zijn om de werknemer te scholen. Een hoge omloop van het personeelsbestand vermindert daarom de investeringen in menselijk kapitaal, hetgeen een negatief effect op de productiviteit heeft.

Becker (1993) maakt onderscheid tussen investeringen in algemeen en specifiek menselijk kapitaal. Algemeen menselijk kapitaal bestaat uit vaardigheden die in meerdere bedrijven en bedrijfstakken productief kan worden aangewend.

Bijvoorbeeld een administratieve medewerker die getraind wordt in het omgaan met veelgebruikte software. Bij specifiek menselijk kapitaal gaat het om vaardigheden die alleen maar nuttig zijn voor één specifiek bedrijf of sector. Omdat een algemene investering bruikbaar is in meerdere bedrijven en de werknemer diegene is die profiteert van de opbrengsten van deze investeringen (in de vorm van hogere productiviteit en hoger loon) zullen de kosten van algemene investeringen in menselijk kapitaal eerder door de werknemer worden betaald dan door de werkgever. Bij investeringen in specifiek menselijk kapitaal zal eerder de werkgever dan de werknemer de kosten dragen; immers, de werknemer kan een hierdoor verhoogde productiviteit niet realiseren bij een andere werkgever. Wel kan de werknemer na zijn training dreigen het bedrijf te verlaten waardoor hij de werkgever de kans ontneemt om het rendement op de investering in het (specifieke) menselijk kapitaal van die werknemer terug te verdienen. Om dit te vermijden biedt de werkgever een deel van de opbrengsten van de investering aan de werknemer aan, in ruil voor een bijdrage in de kosten van investering. In het model van Becker wordt door zowel de werkgever als de werknemer in specifiek menselijk kapitaal geïnvesteerd en ze profiteren samen van de opbrengsten 
(zie ook Leuven 2003). Een gezamenlijke investering van werkgever en werknemer is ook realistisch, omdat de kennis en vaardigheden die tijdens een training on the job worden overgebracht meestal een mix van algemene en specifieke elementen betreft.

Becker (1993) veronderstelt een perfect werkende arbeidsmarkt. In een imperfect werkende markt met imperfecte contracten echter, doen zich meestal twee vormen van marktfalen voor die beide suboptimale investeringen in menselijk kapitaal tot gevolg hebben: de poaching externality en het hold up probleem. Het laatste, dat inhoudt dat de werknemer dreigt op te stappen als hij door opleiding meer waard is geworden, blijft hier buiten beschouwing. Onderinvestering wegens de poaching externaliteit is in zekere zin het spiegelbeeld en dreigt wanneer de werkgever minder zal investeren in het menselijk kapitaal van zijn werknemers, omdat er een kans is dat de werknemer voortijdig het bedrijf verlaat en in een ander bedrijf gaat werken. Als een werkgever goed kan schatten wat de kansen zijn dat een werknemer wordt weggekocht of zelf weggaat na de investering, dan zal hij daarmee rekening houden en een deel van de investeringskosten bij de werknemer leggen. De omvang van de poaching externaliteit hangt dus samen met de externe flexibiliteit op de arbeidsmarkt.

\subsubsection{VASTZITTEN IN EEN BAAN}

De vrijwillige mobiliteit van de ene vaste baan naar de andere is minder groot dan werknemers zouden wensen. De meeste werknemers ervaren wel verschillen tussen wat zij van een baan verwachten en de baan die zij in werkelijkheid hebben. Het kan gaan om onvrede over de werkuren, om de aansluiting tussen arbeidsvaardigheden en functie-inhoud of om een gebrek aan waardering. Dergelijke verschillen zijn een drijfveer voor transities naar een andere baan (De Koning et al. 2003). Die verschillen leiden er echter niet bij iedereen toe dat men daadwerkelijk naar een andere baan zoekt. Gesthuizen en Dagevos (SCP 2005) signaleren dat laagopgeleiden, ouderen en werkenden met kinderen relatief vaak wel verschillen ervaren tussen feitelijke en gewenste baankenmerken, maar dat zij geen zoekgedrag vertonen. $\mathrm{Zij}$ signaleren dat zoekgedrag ook niet bij alle groepen tot dezelfde resultaten leiden. In het bijzonder leidt het zoekgedrag van lager opgeleiden tot minder resultaat.

Voor werknemers die ontevreden zijn met hun werk maar daarop geen actie nemen valt de kostenbaten balans van het zoeken naar een andere baan negatief uit. Daar zijn verschillende factoren verantwoordelijk voor. Het kan te maken hebben met het wegzakken van alternatieve mogelijkheden voor deze werknemer. Bijvoorbeeld iemand die jarenlang als bedrijfsjurist heeft gewerkt, heeft minder mogelijkheden om zich als advocaat te vestigen of rechter te worden dan jaren geleden toen zij net klaar was met haar studies. Vastzitten heeft vaak ook te maken met persoonlijke omstandigheden van de werknemer. Denk aan een werknemer met een werkende partner en van wie de kinderen op school zitten. Deze werknemer is min of meer gebonden aan de plek waar ze woont. Hij of zij 
kan natuurlijk forenzen naar een andere werkplek, maar dat is ook niet altijd aantrekkelijk en beperkt qua afstand. Van deze vastzittende werknemers wordt vaak gezegd dat hun werkgever monopsoniemacht over hen heeft. Naarmate een werknemer minder mobiliteitsmogelijkheden heeft wordt de monopsoniemacht over hem van de werkgever groter. Met mobiliteitsmogelijkheden bedoelen we dat de werknemer snel een andere baan kan vinden of daar in elk geval mee kan dreigen. Een werknemer zonder alternatieven op de arbeidsmarkt is machteloos. Omgekeerd: de macht van de werkgever wordt kleiner naarmate de werknemer meer mogelijkheden tot mobiliteit heeft.

\section{$3 \cdot 5$ CONCLUSIES}

Een perfect werkende arbeidsmarkt zou leiden tot het optimale niveau van baanwisseling. Maar de markt werkt niet perfect en door gebrek aan informatie, door kosten van mobiliteit, coördinatieproblemen en externe effecten van investeringen in menselijk kapitaal op bedrijfsniveau kan er maatschappelijk gesproken zowel te veel als te weinig mobiliteit bestaan op de arbeidsmarkt. Over een langere periode blijkt dat de externe mobiliteit op de arbeidsmarkt relatief constant is. De druk die een aantal trendmatige ontwikkelingen op de arbeidsmarkt zetten heeft blijkbaar niet geresulteerd in een grotere externe mobiliteit. In zekere mate afhankelijk van de stand van de conjunctuur is de externe mobiliteit overwegend vrijwillig. Onvrijwillige mobiliteit leidt behalve tot werkloosheid ook tot neerwaartse mobiliteit. Dit is vooral het geval wanneer de werknemer een langere baanduur had. Aan de andere kant zijn er ook werknemers die wel mobiel zouden willen zijn maar daar niet in slagen. 


\section{FLEXIBILITEITSSTRATEGIEËN VAN BEDRIJVEN EN DE INTERNE ARBEIDSMARKT}

\subsection{INLEIDING}

Bedrijven opereren in een dynamische omgeving. Ze ontmoeten concurrentie op hun afzetmarkten en worden daardoor aangezet om scherp op prijs en kwaliteit te letten en hun producten en processen aan te passen. De afzet van bedrijven is meestal conjunctuurgevoelig, dalend in een recessie en stijgend in een opleving. Overheidsinstellingen en andere arbeidsorganisaties zijn minder afhankelijk van de tucht van de markt, maar ook budgetten blijven niet onveranderd en politieke beslisprocessen zijn soms net zo grillig als de conjunctuur in de markt. De dynamiek van de afzetmarkt en de budgettaire discipline stellen eisen aan de flexibiliteit van de factor arbeid. Voor een belangrijk deel wordt die flexibiliteit gevonden op de externe arbeidsmarkt. Via het aantrekken of ontslaan van werknemers kan een bedrijf of instelling zijn werkgelegenheid aanpassen aan de veranderingen in de productie. Verder is er ook natuurlijk verloop van medewerkers. Het betreft hier de externe flexibiliteit die primair in het vorige hoofdstuk is behandeld. Het accent lag daar op de stromen op de arbeidsmarkt van baan naar en baan, en de processen en overwegingen die daarbij een rol spelen.

Naast flexibiliteit via de externe arbeidsmarkt is interne flexibiliteit, die gerealiseerd wordt binnen bedrijven met het zittende personeelsbestand, van belang. Hierbij wordt meestal onderscheid gemaakt tussen numerieke flexibiliteit en functionele flexibiliteit. Functionele flexibiliteit doet zich voor wanneer werknemers van functie wisselen, andere taken gaan verrichten binnen het team of de afdeling, of op andere projecten inzetbaar zijn. De feitelijke mogelijkheden tot functionele flexibiliteit hangen van verschillende factoren af, zoals de ruimte die de formele arbeidsverhouding biedt, de omvang van het bedrijf en de geschiktheid van werknemers om een andersoortige functie te vervullen. Numerieke flexibiliteit is een ruim begrip, dat primair betrekking heeft op veranderingen in de inzet van de vaste kern van werknemers door hun arbeidsuren aan te passen, bijvoorbeeld door de roosters en werktijden te variëren. Een andere vorm van numerieke flexibiliteit ontstaat wanneer bedrijven gebruikmaken van andere contractvormen dan vaste standaardarbeidsovereenkomsten, bijvoorbeeld door oproepcontracten en deeltijdovereenkomsten.

Sinds enkele decennia blijkt er een nog steeds groeiende behoefte bij bedrijven en instellingen te bestaan aan flexibilisering van de factor arbeid. Deze behoefte lijkt blijvend te zijn, en is dus niet uitsluitend ingegeven door conjuncturele veranderingen. Het gaat hier om structurele ontwikkelingen waarop in hoofdstuk 2 al is ingegaan. Waar het in dit hoofdstuk om gaat, is dat die structurele ontwikkelingen hun invloed hebben op de werking van de interne arbeidsmarkt en de daarbij geldende randvoorwaarden, op de manier waarop bedrijven de inzet van de factor arbeid regelen en soms zelfs op de bedrijfsorganisatie zelf. 
Op het punt van de functionele flexibiliteit op de interne arbeidsmarkt staan de beperkingen van de traditionele, individuele en collectieve arbeidsovereenkomsten ter discussie; en krijgen de maatregelen ter vergroting van de inzetbaarheid (employability) van werknemers meer aandacht. Beide ontwikkelingen bieden overigens ook aanknopingspunten voor een grotere externe mobiliteit. Bij de numerieke flexibiliteit zijn de veranderingen ingrijpender, in die zin dat de grens tussen de interne en de externe arbeidsmarkt ook werkelijk vervaagt. Door opkomst van tijdelijke en flexibele contracten en de inschakeling van uitzendkrachten, freelancers en zelfstandige professionals (zzp'ers) is er als het ware een flexibele schil ontstaan rond de vaste kern van medewerkers met een contract voor onbepaalde tijd. In feite wordt in dit soort gevallen dus gebruikgemaakt van de externe arbeidsmarkt. Ook bij outsourcing en offshoring, waarbij door werk naar binnen- of buitenlandse bedrijven over te dragen een onderneming zich op haar kernactiviteit toespitst, komt de externe arbeidsmarkt in beeld, zeker als 'oude' werknemers met het werk meeverhuizen. Tegelijk zijn deze verschijnselen te beschouwen als veranderingen die de flexibiliteit op de interne arbeidsmarkt verkleinen, doordat daar de variatie in functies vermindert.

De aangestipte ontwikkelingen zijn, naar het zich laat aanzien, nog niet afgerond. Dat de zekerheid en duurzaamheid van de arbeidsverhouding gemiddeld minder vanzelfsprekend zijn dan nog niet zo lang geleden, en dat zij dat voorlopig zullen blijven, is echter duidelijk.

Het hoofdstuk ${ }^{1}$ begint met een bespreking van de ontwikkeling van de interne arbeidsmarkt (par. 4.2). ${ }^{2}$ Dan volgt een empirische analyse van interne flexibiliteit, een beschrijving van de kenmerken van de werknemers op de interne arbeidsmarkt in Nederland, en een aanduiding van enkele signalen van het afnemend belang van de interne arbeidsmarkt (par. 4.3). In de volgende twee paragrafen worden veranderingen uitgewerkt. In paragraaf 4.4 wordt aandacht besteed aan twee aspecten die vooral voor de functionele flexibiliteit van belang zijn, arbeidsovereenkomsten en andere instituties op de interne arbeidsmarkt (subpar. 4.4.1), en het investeren in medewerkers op de interne arbeidsmarkt (subpar. 4.4.2). De transformatie van de interne arbeidsmarkt door andere organisatievormen en inschakeling van buitenstaanders vormen het thema van paragraaf $4 \cdot 5$. Conclusies staan in paragraaf 4.6 .

\subsection{INTERNE ARBEIDSMARKTEN}

In de jaren vijftig en zestig publiceerde een aantal meer institutioneel georiënteerde arbeidseconomen empirische studies die duidelijk maakten dat allocatie van arbeid niet alleen verloopt volgens het eenvoudige vraag- en aanbodmodel van de externe arbeidsmarkt. Werknemers bewegen niet vrijelijk tussen bedrijven en banen; lonen convergeren niet maar verschillen afhankelijk van de omvang en sector van het bedrijf. De meeste werknemers blijven bij hun werknemer, zelfs als ze op een andere plaats meer kunnen verdienen, en werkgevers verlagen de lonen niet voor oudere en minder productieve werknemers, zelfs niet als de lonen bij de concurrentie lager zijn. Doeringer en Piore definieerden in hun 
standaardwerk over de interne arbeidsmarkt uit 1971 deze als "an administrative unit within which pricing and allocation of labor is governed by a set of administrative rules and procedures" (Doeringer en Piore 1971). De interne arbeidsmarkt heeft eigen administratieve regels voor de inzet en het belonen van arbeid die niet onmiddellijk worden beïnvloed door de wetten van vraag en aanbod van de externe arbeidsmarkt. De interne arbeidsmarkt wordt gekenmerkt door 'interne baanladders', regels voor interne promotiekansen, aangewezen plaatsen voor zijwaartse instroom, hiërarchische classificaties van taken en banen, bedrijfsspecifieke scholing, impliciete of expliciete regels voor beloning, bevordering en ontslagbescherming naar anciënniteit en secundaire arbeidsvoorwaarden die het vertrek van werknemers moeten ontmoedigen en de loyaliteit aan het bedrijf versterken.

Later is verder genuanceerd door introductie van het begrip 'bedrijfsgebonden interne arbeidsmarkt', die zich kenmerkt door een zekere mate van geslotenheid. Verwezen wordt dan naar de positie van alle werknemers in bijvoorbeeld een bank, een fabriek, een productiebedrijf of een ziekenhuis. Bij een bedrijfsinterne arbeidsmarkt heeft de werkgever doorgaans sterk geïnvesteerd in de vaardigheden van de medewerkers. Hun kwalificaties hebben in dat geval een sterk bedrijfsspecifiek karakter en bij grotere bedrijven bestaat in Nederland niet zelden een eigen bedrijfs-cao. Bij dergelijke bedrijven met een bedrijfsinterne arbeidsmarkt bestaat meestal een sterke organisatiecultuur, men is Heinekengroen, Randstad-blauw, of men maakt carrière in de publieke dienst. In dergelijke organisaties bestaan doorgaans allerlei verticale loopbaankansen, maar voor het bereiken van de toplagen in de organisatie moeten personen niet alleen over uitstekende vaardigheden beschikken, maar ook beantwoorden aan de bedrijfsspecifieke codes en verwachtingen. ${ }^{3}$

Volgens Doeringer en Piore (1971) hebben zowel werkgevers als werknemers baat bij de wijze waarop de interne arbeidsmarkt is georganiseerd. Naast het terugdringen van het verloop van ervaren en net ingewerkte werknemers en de besparing op rekruteringskosten, zijn werkgevers gebaat bij informele on-the-job training van nieuwkomers door ervaren werknemers. Oudere werknemers zullen dat alleen doen als hun baan zeker is en ze niet pardoes door de net ingewerkte goedkopere arbeidskrachten zullen worden vervangen. Vanuit het perspectief van de werknemer biedt de interne arbeidsmarkt de belofte van hogere beloning en mogelijk promotie na jaren van trouwe dienst en zekerheid tegen het risico van ontslag op oudere leeftijd.

\subsection{DE EMPIRIE VAN DE INTERNE ARBEIDSMARKT IN NEDERLAND}

\subsubsection{BARSTEN IN DE BAANZEKERHEID}

Al geruime tijd wordt vrij algemeen geaccepteerd dat de baan voor het leven zijn langste tijd gehad heeft. Eigenlijk heeft de baan voor het leven nooit voor iedere werknemer bestaan en is deze voorbehouden aan een beperkt deel van de 
beroepsbevolking. Er is aan de ene kant een aantal grote bedrijven ( $>500$ personen) waar gedwongen ontslagen in het verleden praktisch nooit voorkwamen (Jacobs 2004). Deze bedrijven nemen ruwweg een derde van de werkgelegenheid voor hun rekening. Hier werden langdurige loopbanen opgebouwd. Schommelingen in de vraag naar arbeid werden opgevangen door natuurlijk verloop en vanaf een gegeven moment ook door vervroegde uittreding.

Ondertussen zijn ook bij de grote bedrijven barsten in de baanzekerheid gekomen. Ook grote bedrijven voeren nu van tijd tot tijd reorganisaties door waarbij gedwongen ontslagen onvermijdelijk zijn. Niettemin zijn werkgevers in Nederland volgens Jacobs (2004) over het algemeen terughoudend met het doorvoeren van gedwongen ontslagen.

Werknemers werken gemiddeld ruim negen jaar bij dezelfde baas. Volgens cijfers van het CBS schommelde tussen 1992 en 2001 het gemiddelde aantal dienstjaren van de werkzame beroepsbevolking tussen de 9 en de 9,5 jaar (CBS 2003). In figuur 4.1 komt naar voren dat de overgrote meerderheid van de nog werkende 55- tot 64-jarigen al langer dan 20 jaar een dienstverband bij dezelfde werkgever heeft. De staven tellen per leeftijdscategorie op tot 100 procent. Verder werkt een ruime meerderheid van de 45- tot 54-jarigen al langer dan 1o jaar bij dezelfde werkgever. Zelfs is het zo dat al ruim 40 procent van de 35 - tot 44 -jarigen al langer dan 1o jaar bij dezelfde werkgever in dienst is.

\section{Figuur 4.1 Anciënniteit in bedrijven naar leeftijd (1999)}

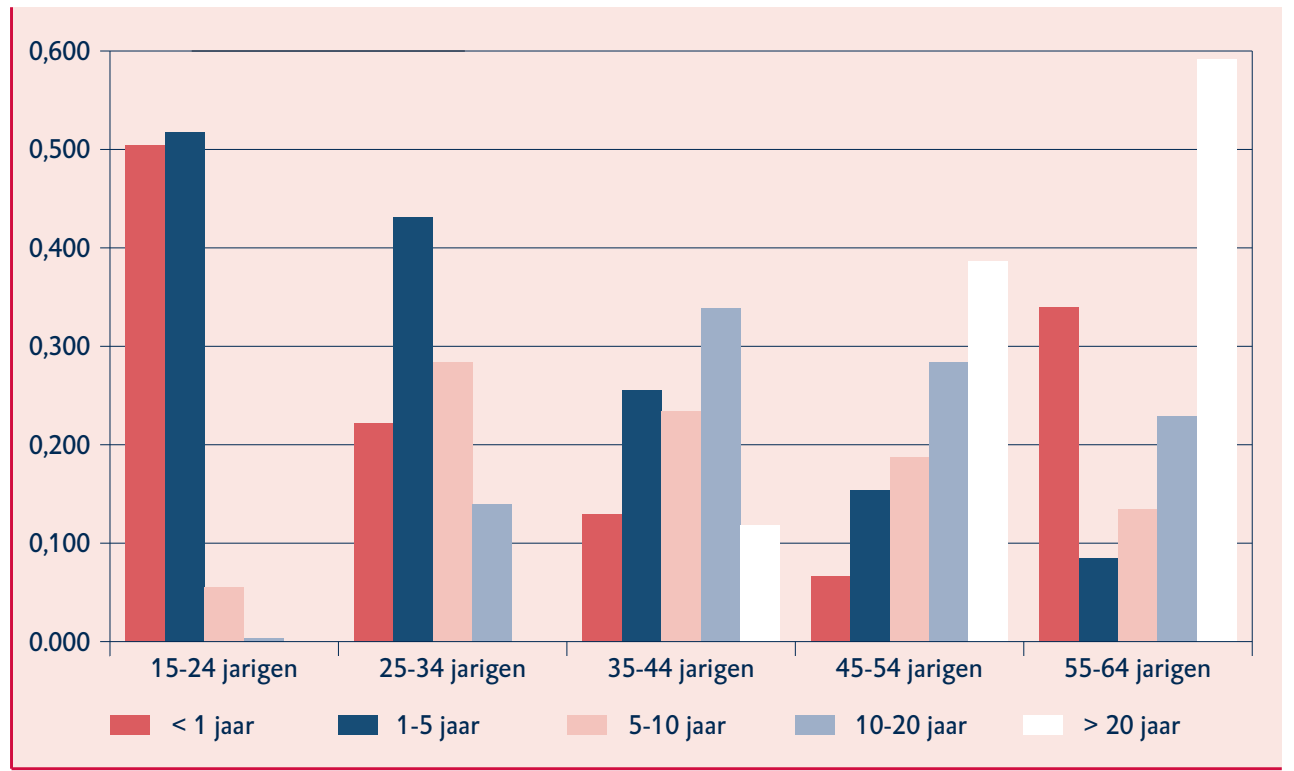

Bron: CBS SSB 
Opvallend is dat van de 55- tot 64-jarigen ruim een op de tien korter dan vijf jaar bij dezelfde werkgever in dienst is. Werknemers zijn behoorlijk honkvast, maar er is blijkbaar ook op hogere leeftijd nog wel enige mobiliteit mogelijk. Hier staat echter tegenover dat de participatie met de leeftijd afneemt, vooral na het vijftigste levensjaar. De participatie van ouderen is de laatste jaren wel sterk gegroeid, maar de uitval van oudere werknemers uit het arbeidsproces is nog steeds groter dan het aandeel baanwisselaars.

\subsubsection{KENMERKEN VAN DE BLIJVERS OP DE INTERNE ARBEIDSMARKT}

Interne arbeidsmarkten worden bevolkt door blijvers. Daarmee bedoelen we werknemers die al langer bij een bepaald bedrijf werkzaam zijn. Langdurige dienstverbanden zijn vooral te vinden bij de grotere bedrijven. Voor een interne arbeidsmarkt is een minimum bedrijfsgrootte vereist; bij een bedrijf met een enkele medewerker zijn er geen loopbaanpaden. In Nederland heeft slechts een klein deel van de bedrijven een grootte van meer dan 50 personen. Toch is het grootste gedeelte van de werkgelegenheid geconcentreerd bij 19 duizend bedrijven met meer dan 50 banen. In totaal bedraagt de werkgelegenheid hier 5,2 miljoen werknemers, tegen 2,2 miljoen banen in 347 duizend kleinere bedrijven (<50 banen). Externe mobiliteit komt vaker voor bij kleine dan bij grote bedrijven. Van de totale baanwisseling vindt ruim 40 procent plaats bij die kleinere bedrijven (terwijl ze goed zijn voor niet meer dan 30 procent van de werkgelegenheid). De industrie kent veel relatief grote bedrijven en daar hebben veel mannelijke werknemers een lange baanduur. Er zijn ook uitzonderingen op de regel. In de gezondheidszorg, een sector met relatief grote bedrijven, overheersen korte dienstverbanden. Het is opmerkelijk dat dit een bedrijfstak is met relatief veel vrouwelijke werknemers. In de bouw werken veel werknemers ( 55 procent) bij relatief kleine bedrijven en desondanks kennen mannelijke werknemers hier een lange baanduur bij hetzelfde bedrijf. Een korte baanduur, voor zowel mannen als vrouwen, komt vaak voor bij de groothandel, de horeca en de detailhandel. Deze korte baanduur is bovendien geconcentreerd bij deeltijders. Het bankwezen, de zakelijke dienstverlening, het onderwijs en de overheid kennen alle lange baanduren voor zowel mannen als vrouwen, in voltijd en deeltijd.

In het kleinbedrijf bestaat wel grote functionele flexibiliteit. Medewerkers ondersteunen elkaar en vangen pieken en dalen in de productie gezamenlijk op.

Blijvers hebben een aantal opvallende kenmerken. Blijvers zijn relatief vaker man dan vrouw, en werken vaker voltijd dan deeltijd. Hiermee staat in verband dat blijvers eerder in de hoogste decielen van de inkomensverdeling voorkomen dan in de laagste decielen: Niet minder dan 70 procent van degenen die al langer dan 1o jaar bij eenzelfde werkgever zit, heeft een inkomen dat in een van de bovenste drie decielen valt. Overigens bevinden zich bij bedrijven waar veel langdurige dienstverbanden zijn, ook altijd werknemers met kortdurende dienstverbanden die in de laagste decielen van de inkomensverdeling te plaatsen zijn. Zoals reeds eerder aangegeven is er blijkbaar in bedrijven met een kern van vaste werknemers ook een schil aanwezig van flexibele werknemers. 


\section{Tekstbox 4.1 De duale economie}

De theorie van de duale economie legt de nadruk op verschillen tussen sectoren en bedrijven. Een groep bedrijven bezit duidelijke gemeenschappelijke kenmerken die wordt aangemerkt als behorende tot de kern. Als typische kenmerken gelden: groot van schaal en dominant op de markt. De rest van de bedrijven, dus klein, blootgesteld aan concurrentie zit in de periferie. Belangrijkste oorzaken van die differentiatie zijn vooral concentratie en technologie.

De arbeidsmarkt wordt daarmee als het ware verdeeld in een beperkt aantal segmenten: een 'hoge lonen' kern die is samengesteld uit bedrijven met een interne arbeidsmarkt en een lage lonen periferie, die bestaat uit bedrijven die hun arbeid verkrijgen op de externe markt. Het belangrijke onderscheid tussen die soorten bedrijven loopt via de relatie goede en slechte banen en niet via geschoolde en ongeschoolde medewerkers. Werknemers die aangewezen zijn op de periferie ontwikkelen een patroon van baaninstabiliteit: wisselingen, statuswisselingen naar werkloosheid en inactiviteit. Verder valt op dat de mobiliteit tussen kern en periferie beperkt zo niet afwezig is, waardoor geschoolde werkers die aangewezen zijn op een perifere markt tegen lage lonen beperkt geschoold werk moeten doen. Omdat de lonen binnen een interne arbeidsmarkt hoger zijn dan op de externe, roept dit de vraag op naar de allocatieve efficiency.

In de periferie is er geen prikkel voor werkgevers en werknemers om een stabiele werkrelatie te ontwikkelen. Werknemers die hier terechtkomen zijn in het begin even goed als die in de kern. $\mathrm{Na}$ een periode gewerkt te hebben in de instabiele en laagbetaalde periferie gaat het mis en ontstaat kwaliteitsvermindering. De kwalitatief slechte banen leiden tot tekortkomingen in de werkhouding en motivatie, en tot ongevoeligheden voor opleidingsmogelijkheden.

\subsubsection{STROMEN OP DE INTERNE ARBEIDSMARKT}

Een van de eerste empirische metingen van creatie en destructie van banen en van de in-, uit- en doorstroom in individuele personen in Nederland is van de hand van Hamermesh, Hassink en Van Ours (1996). Ze maten de instroom van nieuwe werknemers in het bedrijf, de (vrijwillige en onvrijwillige) uitstroom uit het bedrijf en de doorstroom binnen hetzelfde bedrijf van de ene werkplek of functie naar de andere. De instroom vanuit de externe arbeidsmarkt naar banen binnen een bedrijf bedraagt 11,9 procent (als een percentage van de werkgelegenheid). De uitstroom naar de externe arbeidsmarkt bedraagt 10,1 procent. De totale doorstroom binnen het bedrijf van de ene baan naar de andere, die een indruk geeft van de omvang van de functionele flexibiliteit, wordt gemeten op 3,4 procent.

In een empirische studie over de flexibiliteit op de Nederlandse arbeidsmarkt vergelijken de auteurs het niveau van de flexibiliteit van baan tot baan met die van functie naar functie (beide gemeten als een percentage van de beroepsbevolking) voor de periode 1986-1996 (Zant et al. 200o). In figuur 4.2 zijn beide vormen van flexibiliteit samengebracht. Duidelijk is dat de externe flexibiliteit van baan naar baan bijna twee keer zo omvangrijker is als de interne mobiliteit van functie naar functie. De flexibiliteit van baan naar baan schommelt rondom 9 procent van de beroepsbevolking. De flexibiliteit van functie naar functie schom- 
Figuur 4.2 Externe en interne wisselingen

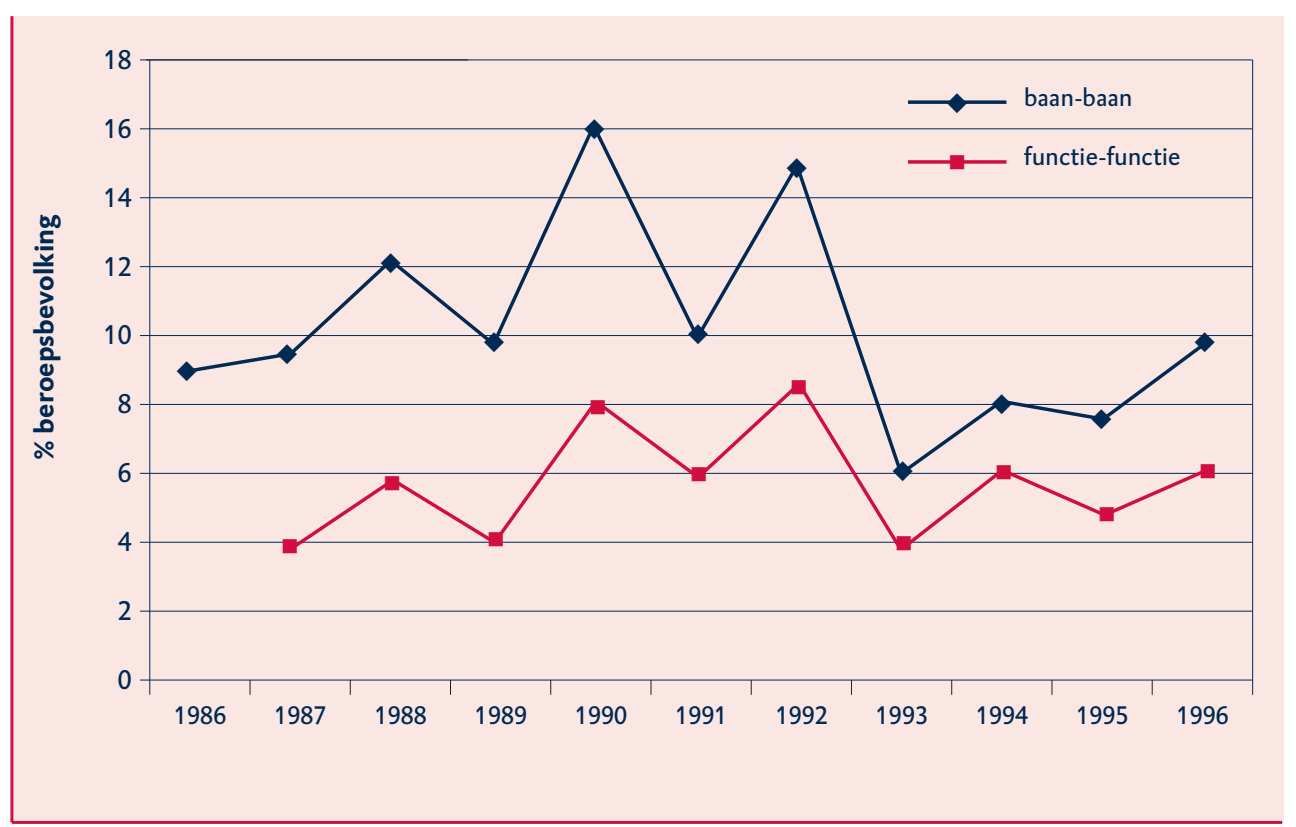

Bron: WRR op basis Zant et al. (200o: fig. 2.1 en 2.2)

melt rondom de 5,5 procent. Beide vormen van flexibiliteit vertonen een vergelijkbaar cyclisch patroon (hoog in een hoogconjunctuur, laag in een recessie).

De twee behandelde empirische studies definiëren flexibiliteit van functie naar functie niet op exact dezelfde manier. Maar beide maken duidelijk dat de beweeglijkheid van de interne arbeidsmarkt kleiner is dan de beweeglijkheid van en naar de externe arbeidsmarkt. In de oorspronkelijke theorie over de interne arbeidsmarkt werd gesteld dat een interne arbeidsmarkt slechts een beperkt aantal toegangspoorten (entry ports) kende, die meestal gesitueerd waren aan de onderkant van de competentieverdeling en dat de vervulling van banen vooral via interne doorstroom en promotie zou worden gerealiseerd. Die oorspronkelijke hypothese is in de loop van de tijd verlaten. De cijfers die hier worden getoond ontkrachten ook het relatieve belang van dergelijke toegangspoorten. Uit figuur 4.2 blijkt duidelijk dat externe en interne flexibiliteit eerder complementen zijn (ze vullen elkaar aan en zijn beide op hetzelfde moment hoog dan wel laag) dan substituten (die eerder tegengestelde bewegingen in de tijd zouden laten zien).

Gebruikmakend van gegevens over oudere werknemers (tussen 43 en 63 jaar oud), onderzochten Hebbink c.s. de mobiliteit van oudere werknemers (Hebbink et al. 1996). Daarbij werd ook aandacht besteed aan interne functiewisselingen. Uit hun gegevensbestand blijkt dat ongeveer 44 procent van de werknemers in loondienst naar eigen zeggen ooit (tijdens hun loopbaan) binnen het bedrijf van functie is veranderd. Een kwart van de functiewisselaars deed dat zelfs meerdere 
malen. Meestal vinden functiewisselingen (net als baanwisselingen in het vorige hoofdstuk) op jongere leeftijd plaats. Er worden ook gegevens gepubliceerd over de gemiddelde functieduur. Dat is de duur dat een werknemer bij dezelfde werkgever in dezelfde functie blijft werken. De gemiddelde functieduur is 6 jaar (de gemiddelde baanduur circa 9 jaar). Meestal gaan werknemers er qua inkomen op vooruit na een functiewisseling. Dat geldt ook voor de oudste leeftijdgroepen.

Het Sociaal en Cultureel Planbureau heeft verschillende OSA-data bijeengebracht in de studie Arbeidsmobiliteit in goede banen (SCP 2005). Daaruit blijkt dat over een periode van twee jaar van alle mensen die zijn blijven werken, bijna twee derde $(64,1$ procent) bij dezelfde werkgever en in dezelfde functie blijft. Binnen hetzelfde bedrijf heeft 11,7 procent een andere functie gekregen en 17,3 procent is overgestapt naar een andere werkgever. Zoals ook al eerder bleek, dalen zowel de externe als de interne mobiliteit met de leeftijd. Tussen het veertigste en het vijftigste levensjaar bereiken veel werknemers een eindpunt binnen de organisatie waar ze werken. Hun kansen op het vinden van een betere baan op de externe markt worden ook kleiner. Dit zou kunnen wijzen op het probleem van een midcareer impasse (Diprete et al. 1987). Visser en Van der Meer (2007) bespreken de voorbeelden van ambulancebroeders en brandweerlieden die na twintig jaar fysiek belastende beroepsuitoefening toe zijn aan ander werk, dat ze alleen kunnen krijgen indien ze daarvoor ook geschoold en voorbereid worden. Het vraagstuk van de mid-career impasse is ook regelmatig aan de orde geweest in de gesprekken met HR-managers, die ter voorbereiding van dit rapport gevoerd zijn (zie bijlage II). Daar werd onder meer naar deze problematiek verwezen als de 'gouden kooi' waarin werknemers van 45 + vast komen te zitten. Ook werd gesteld dat een bouwvakker van 40 jaar na twintig jaar misschien beter een ander vak zou kunnen gaan uitoefenen. ${ }^{4}$

\subsubsection{HET AFNEMEND BELANG VAN INTERNE ARBEIDSMARKTEN}

Op basis van een uitvoerige literatuurstudie concluderen Visser en Van der Meer (2007) dat er vanaf de jaren tachtig sprake is van een trendbreuk in de groei van de interne arbeidsmarkt. Voorheen was de dominante bedrijfsstrategie gericht op internalisering, bijvoorbeeld door verticale integratie, van bedrijfsonderdelen. Hierdoor neemt de omvang van bedrijven toe en hebben de werknemers door de bedrijfsgroei interne loopbaankansen. Dit verandert als bedrijven van strategie veranderen en overgaan op externalisering, waarbij bedrijfsonderdelen worden afgestoten en de arbeidsverhoudingen steeds flexibeler worden. Hierdoor worden interne bedrijfsmarkten kleiner in omvang waardoor de toegang van werknemers tot de interne arbeidsmarkt ook steeds moeilijker wordt, terwijl tevens de loopbaankansen binnen een organisatie dalen, doordat er steeds minder hiërarchische niveaus zijn. Zij wijzen erop dat de traditioneel strak georganiseerde arbeidsorganisatie nog wel voorkomt in de industrie, bijvoorbeeld met ploegendiensten en lopendebandwerk, maar in de dienstensector steeds vaker wordt vervangen door nieuwe arbeidsarrangementen binnen bedrijven die meer aansluiten bij de eisen van moderne productieprocessen en de voorkeuren van nieuwe generaties werk- 
nemers. Zij bespreken voor acht landen een aantal indicatoren die deze ontwikkeling onderstrepen, waarbij overigens de erosie in de Verenigde Staten veel sterker is dan in Nederland.

Als eerste indicator zien Visser en Van der Meer de opkomst van tijdelijk en uitzendwerk, en het toenemende gebruik van inleenbedrijven en freelancewerk. Op zichzelf betekent deze ontwikkeling niet dat de interne arbeidsmarkt verdwijnt, wel dat ze kleiner wordt. Het naast elkaar werken van werknemers die soms dezelfde activiteiten verrichten of in teams met elkaar samenwerken maar verschillende rechten en vooruitzichten hebben, is op macroniveau een uitdaging aan het arbeidsrecht en de sociale zekerheid en op microniveau, binnen de onderneming, een HRM-probleem dat vragen oproept met betrekking tot competentiemanagement, scholing en mobiliteit van personeel.

Een tweede indicator voor de veranderingen in de aard van de arbeidsverhouding is de toegenomen perceptie van baanonzekerheid. Bij interne arbeidsmarkten past een 'impliciete' of onuitgesproken overeenkomst van baanzekerheid in ruil voor loyale en plichtsgetrouwe inzet. Het bijpassende 'psychologische contract' is gestoeld op de overtuiging dat er een garantie van een blijvend dienstverband bij dezelfde werkgever is gegeven. Veranderingen in de perceptie van baanzekerheid vormen daarom een directe aanwijzing dat in de beleving van werknemers de zekerheden die horen bij een interne arbeidsmarkt, geleidelijk verdwijnen. In de meeste westerse landen beleven werknemers volgens eigen opgave een toename van de onzekerheid van hun werk. Deze stijging wordt in verband gebracht met de toename van de werkloosheid, de opkomst van tijdelijk werk en bedrijfsreorganisaties. Op individueel niveau hangt de perceptie van baanonzekerheid onder meer samen met (hogere) leeftijd, een laag scholingsniveau, en persoonlijke ervaringen met reorganisaties en werkloosheid. Baanonzekerheid gaat ook gepaard met gevoelens van machteloosheid en onvrede over het werk. Dit kan verklaren dat bijvoorbeeld in Nederland in 1998, bij een dalende trend in de werkloosheid, naar verhouding twee keer zoveel werknemers zich onzeker voelden over de toekomst van hun werk als in Denemarken, waar de werkloosheid toen hoger lag.

De derde indicator betreft de afnemende gemiddelde en modale baanduur. Vooral in de Verenigde Staten blijkt in de periode 1983 tot 2001 de modale baanduur sterk teruggelopen te zijn. Voor mannen in de oudste leeftijdsgroep nam de modale baanduur af van 16 tot 11 jaar. De daling was het sterkst voor de groep van laagopgeleide mannen die over het algemeen werkzaam zijn in de industrie. Opmerkelijk zijn de verschillen tussen mannen en vrouwen. De modale baanduur van vrouwen blijkt te stijgen, mogelijk omdat vrouwen vaker doorwerken na het krijgen van een kind (Stone 2004). Voor Nederland ontbreken zulke gedetailleerde tijdreeksen. Eerder in dit hoofdstuk bleek dat hier een lange baanduur nog steeds veelvuldig voorkomt, en dat de verandering naar een kortere baanduur empirisch nog niet duidelijk zichtbaar is. 


\subsection{VERANDERINGEN OP DE INTERNE ARBEIDSMARKT: FUNCTIONELE FLEXIBILITEIT}

\subsubsection{INDIVIDUELE EN COLLECTIEVE ARBEIDSOVEREENKOMSTEN}

De formele (juridische) en informele vormgeving van de interne arbeidsmarkt worden aangestuurd door de arbeidsovereenkomst tussen de werkgever en de werknemer, de collectieve arbeidsovereenkomst en formele en informele regels die gelden binnen de arbeidsorganisatie van het bedrijf of de instelling. Bij die formele regels gaat het om de bepalingen van het arbeidsrecht, de sociale wetgeving en cao's, bij de informele regels om bepaalde gedragsnormen en onuitgesproken verwachtingen die, zoals in elke relatie, de omgang tussen de betrokkenen beïnvloeden. In deze institutionele vormgeving van de interne arbeidsmarkt treden in de afgelopen decennia verschuivingen op. Een aantal hier relevante verschuivingen bij de inhoud en betekenis van de individuele en collectieve arbeidsovereenkomst komt in deze paragraaf aan de orde.

\section{De arbeidsovereenkomst en flexibiliteit van functie naar functie}

Belangrijk voor interne flexibiliteit is het gemak waarmee werkgever en werknemer tot veranderingen in inzet en inhoud van functies kunnen komen binnen de grenzen die door hun gemeenschappelijke arbeidsovereenkomst worden gesteld. Binnen de juridische doctrine wordt onderscheid gemaakt tussen de contractuele visie op de relatie tussen werkgever en werknemer en de meer institutionele benadering (Nagelkerke et al. 2006). In het eerste geval is het contractuele altijd bepalend en moeten alle veranderingen contractueel en in overeenstemming tussen beide partijen worden vastgelegd. Flexibilisering kan alleen op basis van consensus plaatsvinden. In de institutionele benadering wordt het contract gezien als een 'toegangsbewijs' tot een arbeidsorganisatie en worden veranderingen doorgevoerd in het belang van de organisatie. Er wordt eerder van uitgegaan dat de werknemer is opgenomen in een arbeidsorganisatie die zijn productieve bestaan wil continueren. Van de werknemer wordt gevraagd daar de best mogelijke bijdrage aan te leveren, en inhoud en vorm van die bijdrage kunnen in de loop van de tijd worden gewijzigd. De werkgever (als leidinggevende) heeft binnen grenzen de mogelijkheid om interne flexibiliteit van de werknemer te verlangen. Zoals gebruikelijk in de Nederlandse rechtstraditie wordt zowel de contractvisie als de institutionele visie gemitigeerd door eisen van redelijkheid en billijkheid.

Uit de studie van Nagelkerke c.s. (2006) wordt duidelijk dat de juridische aspecten van interne flexibilisering in beweging zijn. De verschuiving gaat van een enigszins strikte toepassing van de contractvisie in het verleden naar een meer institutionele visie. In de loop van de jaren heeft de werkgever binnen bepaalde grenzen de mogelijkheid verworven om de werknemer, binnen grenzen, andere taken en werkzaamheden op te dragen en als het ware eenzijdig de arbeidsomstandigheden te veranderen. Een belangrijke ontwikkeling binnen de rechtstheorie is het begrip 'goed werknemerschap', dat de werknemer binnen redelijke en 
billijke grenzen tot flexibiliteit verplicht. Dit betekent nog altijd niet dat interne flexibilisering nu zonder problemen kan worden doorgevoerd op de Nederlandse arbeidsmarkt: soms moet (met instemming van het CWI) het personeel eerst worden ontslagen om vervolgens met een nieuw contract opnieuw in dienst te worden genomen.

\section{Personeelsbeleid en de cao}

Elke arbeidsorganisatie heeft zijn eigen cultuur. Die bedrijfscultuur heeft een zekere bestendigheid en verandert slechts langzaam in de loop van de tijd. Uit de reeks gesprekken met HR-managers mag voorzichtig geconcludeerd worden dat bedrijfsculturen in Nederland veranderen. De indruk bestaat dat jongere generaties anders en soepeler omgaan met veranderingen dan de oudere generaties. Hoewel Nederland een sterke wettelijke traditie kent (arbeidsovereenkomstenrecht, arbeidstijdenrecht en arbeidsomstandigheden- en ontslagwetgeving), zijn het vooral de veranderingen in generaties van werknemers die toch voor een verschuiving in de bedrijfscultuur zorgen.

In de interviews is ook aan de orde gekomen in welke mate cao's en personeelsreglementen de flexibilisering ten goede komen. Hierbij werden twee tegengestelde bewegingen geconstateerd. Enerzijds bevatten veel cao's zodanig gunstige rechten dat ze de externe mobiliteit van medewerkers belemmeren, een verschijnsel dat bij sommige bedrijven versterkt wordt door extra rechten die daarboven na enkele jaren dienstverband verworven worden. Anderzijds worden in cao's en in sociale plannen afspraken gemaakt om de interne mobiliteit te bevorderen. Bij grotere bedrijven wordt gewerkt met outplacementbureaus en uitzendbureaus bij het vinden van een nieuwe baan, binnen en buiten de organisatie. Soms worden daarvoor aparte 'mobiliteitscao's' afgesproken en worden 'mobiliteitscentra' ingericht die moeten zorgen voor interne en externe herplaatsing van medewerkers die met ontslag worden bedreigd. Vaak worden financiële prikkels ingezet voor werknemers die snel zelf een andere baan vinden. ${ }^{5}$

Sommige bedrijven hanteren flexibiliteiteisen alleen voor hoger opgeleide medewerkers. Andere bedrijven eisen een flexibele inzet van al hun medewerkers.

Sommige bedrijven hanteren een 'mobiliteitstoeslag': een premie voor de werknemer die binnen het bedrijf flexibel is.

Tijdens en Van der Meer (200o) zijn in een survey nagegaan hoe personeelsmanagers denken over de mogelijkheden die de cao biedt voor de flexibilisering van hun personeelsbestand. Zij concluderen dat de cao nauwelijks belemmeringen biedt, maar ook dat bedrijven maar in geringe mate gebruikmaken van de mogelijkheden die de bestaande kaders hen bieden. Dat is ook niet zo vreemd als we in aanmerking nemen dat in veel cao's er ruimte is voor flexibele werktijden en variabele roosters, voor overwerk, het kopen en verkopen van tijd en geld, alsook voor de scholing, persoonlijke ontwikkeling, loopbanen, en inzetbaarheid. 


\subsubsection{IN VESTEREN IN MENSEN OP DE INTERNE ARBEIDSMARKT}

Zoals eerder in dit hoofdstuk is aangegeven, zijn veel dienstverbanden van lange duur, aangezien werkgever en werknemer investeren in een wederzijdse relatie. Het gaat daarbij vooral om de investering van de werknemer in kennis en vaardigheden die nuttig zijn voor zijn productiviteit op de arbeidsmarkt en in het huidige bedrijf in het bijzonder. De discussie over levenslang leren en over inzetbaarheid (employability) sluit hier op aan. In deze discussie wordt altijd gesteld dat de investeringen in het menselijk kapitaal van de werknemer een gezamenlijke verantwoordelijkheid zijn van werkgever en werknemer. De werknemer heeft een verantwoordelijkheid, omdat het de eigen loopbaan betreft en ook het risico dat zelf wordt gelopen. De werkgever heeft een verantwoordelijkheid jegens de werknemer, omdat tekorten in de inzetbaarheid problemen opleveren bij een noodzakelijke wijziging in de personele samenstelling. In deze paragraaf wordt aandacht besteed aan inzetbaarheid en investeringen in menselijk kapitaal op de interne arbeidsmarkt; in het beleidshoofdstuk 7 wordt erop teruggekomen.

\section{Bedrijfsopleidingen}

De laatste jaren is de aandacht voor investeringen in de kennis en competenties van werknemers in de vorm van bedrijfsopleidingen en training on the job toegenomen. Volgens het CBS hebben in 1999 vier van de tien werknemers in het bedrijfsleven één of meer bedrijfsopleidingen gevolgd (tegenover 25 procent zes jaar eerder). Mannen gaan iets vaker op cursus dan vrouwen (44 procent tegenover 34 procent). Er wordt gemiddeld ruim 8 oo euro per werknemer per jaar aan bedrijfsopleidingen besteed in de particuliere sector. Bij de bedrijven, waarmee in de interviewronde gesproken is, variëren de opleidingsbudgetten van 1,4 procent tot 7,5 procent van de loonsom.

Tijdens de interviews kwam het belang van bedrijfsopleidingen ook steeds ter sprake. De mogelijkheden die een baan biedt aan de werknemer om zichzelf verder te ontwikkelen zijn voor de huidige generaties schoolverlaters en jonge werknemers van essentieel belang als arbeidsvoorwaarden. Bij grote bedrijven is het investeren in mensen meestal geen kostenprobleem. Bij het midden- en zeker bij het kleinbedrijf is er vaak geen geld voor opleiding. Hier liggen kansen voor de o\&O-fondsen die niet altijd ten volle worden benut.

Tegelijk moet dit beleid ook enigszins worden genuanceerd; de nadrukkelijke aandacht voor investeringen in werknemers is van vrij recente datum. Volgens de respondenten ontbreekt vaak een duidelijk beleid achter de besteding van de opleidingsbudgetten. Een keuze die niet altijd expliciet wordt gemaakt is of men alleen wil investeren in de high potentials of in alle werknemers. Ook wordt er nog steeds niet of bijzonder weinig geïnvesteerd in werknemers vanaf 40 jaar. Dit heeft een extra negatief effect waar mensen door gedemotiveerd worden en niet meer in zichzelf investeren. Men realiseert zich ook dat men de oudere generaties $\left(55^{+}\right)$in het verleden geheel en al verwaarloosd heeft wat betreft opleiding. Dat is iets wat men nu betreurt. Voor een deel wordt het beleid om in werknemers te 
investeren aangejaagd door de jongere werknemers, die dikwijls bijzonder geïnteresseerd zijn in opleiding. Dit heeft af en toe als resultaat dat bedrijfscursussen (een week op de hei) eerder de vorm hebben van een aantrekkelijke arbeidsvoorwaarde (leuk om te doen) dan dat zij een werkelijke investering zijn. Vooral grote bedrijven willen door opleidingsbudgetten gezien worden als aantrekkelijke werkgever.

\section{Inzetbaarheid van de oudere werknemer}

Tijdens de gesprekken met HR-managers werden vrij veel opmerkingen gemaakt over de 'vastgeroeste' medewerker van veertig en ouder. In Nederland is men gewend om tussen 25 ste en 4 oste levensjaar carrière te maken. Daarna is er weinig doorgroei meer. Bij een ander bedrijf zou men 10-15 procent minder betaald krijgen, dus men blijft (en door het oprekken van de pensioenleeftijd blijft men extra lang). Overigens raken bedrijven er pas de laatste jaren van doordrongen dat oudere werknemers langer moeten blijven werken. Vroeger gingen werknemers er bij grote bedrijven gemiddeld met 55 jaar uit, maar de mogelijkheden tot vervroegde afvloeiing worden steeds beperkter, en de effectieve pensioenleeftijd neigt steeds meer naar 65 jaar.

Er zijn nog veel slagen te maken bij de inzetbaarheid van ouderen. Lange dienstverbanden maken dat men werknemers niet aanspreekt op kwaliteit van werk en prestatie. Bij veel bedrijven is de werkcultuur zodanig dat men mensen niet wijst op slechte prestaties of op de noodzaak te veranderen. Dit heeft geleid tot het ontbreken van urgentiegevoel bij werknemers. Gesprekken met oudere werknemers over hoe ze de laatste jaren van hun carrière zien worden vaak niet eens gevoerd, en in oudere werknemers van boven de 40 jaar wordt vaak niet geïnvesteerd. De belangrijkste lering die men de laatste jaren heeft getrokken is dat men de dure, oudere generaties heeft vergeten mee te trekken in de moderne tijd. In de gesprekken werd opgemerkt dat de oudere werknemers vaak zeer beschermd worden door vakorganisaties, hetgeen soms tot onvrede leidt bij jongere arbeidskrachten op de werkvloer. Ook werd gesteld dat werken voor werknemers van 55-65 jaar over het algemeen niet zo problematisch is als vaak buiten de werkomgeving wordt gedacht. Als het werk toch fysiek belastend is, bijvoorbeeld door de nachtdiensten, dan kunnen roosteroplossingen worden gevonden.

\subsubsection{NAAR EEN NIEUW PSYCHOLOGISCH CONTRACT?}

Organisatiepsychologen gebruiken het begrip 'psychologisch contract' voor de perceptie en verwachtingen die werknemers ten aanzien van hun arbeidsverhouding hebben. Het drukt uit in hoeverre de werknemer gelooft of verwacht dat werknemer en werkgever verplichtingen jegens elkaar hebben die verder gaan dan hun geschreven overeenkomst. Het psychologische contract wordt daarbij gedefinieerd als ..."iemands overtuiging dat er een soort van belofte is gedaan en de contractuele voorwaarden door beide partijen zijn aanvaard." Zo'n psychologisch contract kan gestoeld zijn op de perceptie, verwachting of overtuiging dat 
de tegenpartij een vaste baan in het vooruitzicht heeft gesteld, voorrang zal geven bij bevordering, een vast inkomen garandeert, scholing zal verzorgen of zal helpen bij het vinden van een nieuwe baan. Deze inhouden kunnen verschillen, sommige onderdelen ervan kunnen geformaliseerd en in afspraken vastgelegd zijn, maar doorgaans is het psychologisch contract "impliciet, onuitgesproken en zelden bediscussieerd".

Er is een behoorlijk grote consensus onder organisatiedeskundigen in de Amerikaanse literatuur en praktijk dat het oude psychologische contract, gebaseerd op de belofte van baanzekerheid, interne promotie en een stabiel en groeiend (pensioen)inkomen, niet meer bestaat. Eigen verantwoordelijkheid voor carrièreontwikkeling en sterkere binding aan (de inhoud van) het werk nemen de plaats in van binding aan de organisatie. De verwachtingen tegenover het werk richten zich op de ontplooiingskansen die het werk biedt en op de gelegenheden voor netwerken naar een volgende baan.

\subsection{TRANSFORMATIE VAN DE INTERNE ARBEIDSMARKT}

In deze paragraaf worden enkele ontwikkelingen geschetst die aangeven hoezeer de onderneming die bijna uitsluitend werkt met 'eigen' arbeidskrachten op contracten van onbepaalde duur aan het verdwijnen is; zij illustreren de verkleining en daarmee het afnemende belang van de interne arbeidsmarkt.

\subsubsection{KERN EN PERIFERIE}

De verschuiving van de bedrijfsstrategie van internalisering naar externalisering leidt ertoe dat er binnen arbeidsorganisaties meer aandacht kwam voor de flexibele inzet van de vaste medewerkers. In Nederland is de ontwikkeling overigens lang niet zo ver doorgevoerd als in de Verenigde Staten. Dat komt ongetwijfeld door de positie van de vakbeweging, de grote dekking van cao's en de rechten van werknemers op advies, informatie en consultatie met de ondernemingsleiding (zie Visser en Van der Meer 2007).

In de literatuur wordt gesteld dat de numerieke flexibilisering eerder ontstond dan functionele flexibilisering (zie Schippers et al. 2001). Een uitzendbedrijf als Randstad ging vanaf midden jaren zestig personeelsdiensten aanbieden aan bedrijven. Zieke werknemers konden worden vervangen, en bij pieken in de productie konden uitzendkrachten vaste werknemers bijstaan. Deze vorm van externe numerieke flexibilisering maakt het mogelijk dat de personeelsomvang varieert met de afzetmarkt. Na een geleidelijke groei, is het uitzendwerk vooral in de jaren negentig sterk gestegen, om na de conjuncturele neergang van het begin van de nieuwe eeuw weer enigszins te dalen.

Na de externe flexibilisering kwam er overigens meer aandacht voor interne of functionele flexibilisering, die de totstandkoming van optimale personeelsinzet kan bevorderen. Als reden werd genoemd dat de wal van de noodzakelijke 
bedrijfscontinuïteit het schip van de voortgaande flexibilisering keerde (Schippers et al. 2001). Bedrijven hebben belang bij gemotiveerde en loyale arbeidskrachten, en die loyaliteit zou op de proef gesteld kunnen worden als er te veel uitzendkrachten werkzaam zijn in een organisatie. ${ }^{6}$ Bovendien willen werknemers in vaste dienst zich verder ontwikkelen en een groei doormaken in hun loopbaan.

Uit de interviews met HR-managers blijkt dat veel bedrijven beschikken over een vaste kern en daaromheen een schil van flexibele medewerkers. Deze flexibele schil varieert bij de betrokken bedrijven tussen de 10 en 20 procent van het personeelsbestand. De samenstelling van de schil kan variëren. Uitzendkrachten zijn er meestal onderdeel van, maar er zijn ook andere vormen van flexwerkers, zoals werknemers gedetacheerd uit een arbeidspool of van detacheringsbedrijven. Een dergelijke constructie met een flexibele schil gaat gepaard met uitgaven voor de bemiddeling en detachering, reden waarom in het MKB minder gebruik wordt gemaakt van uitzendkrachten, en meer van flexibele arbeidstijden en deeltijdcontracten.

Tot de flexwerkers worden meestal gerekend: de thuiswerkers, uitzendkrachten, seizoenswerkers, vakantiewerkers en andere tijdelijke arbeidskrachten. Maar er zijn nog andere mogelijkheden zoals het uitbesteden van werk aan freelancers en zzp'ers, het inlenen van medewerkers van andere werkgevers (detachering) en het opzetten van arbeidspools. De Nederlandse arbeidsmarkt telt relatief veel flexwerkers en het aantal zzp'ers en freelancers neemt toe. Flexibele arbeid komt relatief veel voor onder jongere werknemers. Relatief veel personen met een algemeen vormende of een voorbereidende opleiding (havo/vwo of vmbo) als hoogst genoten opleiding hebben flexibele arbeidscontracten. Flexibele contracten komen ook aanzienlijk meer voor bij onderwijs volgende jeugdigen dan bij niet onderwijs volgende jeugdigen. Flexibele arbeid van jeugdigen betreft hoofdzakelijk arbeid op het elementaire en lagere beroepsniveau. In de leeftijdscategorie ouder dan 45 jaar komt flexibele arbeid betrekkelijk weinig voor; de toename van de arbeidsparticipatie vindt daar plaats in vaste dienstverbanden of als zelfstandige.

Het lijkt er echter op dat het gebruik van flexibele arbeid na een aanvankelijke sterke opkomst tegen zijn grenzen oploopt (Oeij et al. 2002). Dit heeft deels conjuncturele redenen, maar heeft waarschijnlijk ook te maken met de strengere eisen die aan flexwerk worden gesteld in de Wet flexibiliteit en zekerheid uit 1999. Het ligt voor de hand dat het gebruik van flexibele arbeid afhankelijk is van de conjunctuur. Als de economie na een recessie opveert, zullen werkgevers aanvankelijk terughoudend zijn met het aannemen van werknemers in vaste dienst en de voorkeur geven aan flexibele contracten. Ook is het aannemelijk dat tijdens een recessie tijdelijke contracten worden beëindigd. Flexibele arbeid vormt een buffer tegen vraaguitval.

$\mathrm{Na}$ afloop van een recessie zal dus het aandeel van flexibele arbeid toenemen. Dit is ook het patroon dat na de recessie van begin jaren negentig waargenomen is. 
Volgens cijfers van de Enquête Beroepsbevolking van het Centraal Bureau voor de Statistiek is het aantal flexibele contracten sterk gegroeid tot in 1999 een hoogtepunt bereikt werd. Het is denkbaar dat als gevolg van de krapte op de arbeidsmarkt die zich toen voordeed, de groei van het aantal flexibele banen is gestagneerd. Werknemers konden daardoor een vaste baan bedingen. In de daaropvolgende laagconjunctuur is het aantal flexibele banen weer sterk afgenomen. Het is ook vaak zo dat flexibele banen een functie vervullen om vanuit werkloosheid uiteindelijk een vaste baan te bemachtigen. Door een tijdelijke baan te aanvaarden verhogen werklozen de kans op instroom in een vaste baan aanzienlijk (Zijl et al. 2004). Dat geldt voor vrijwel alle categorieën werknemers, inclusief degenen met een zwakke arbeidsmarktpositie. Er wordt echter relatief weinig gebruikgemaakt van deze route. Daardoor blijven kansen op instroom in een vaste baan onbenut. Goed beschouwd zouden langdurig werklozen en, voor zover daartoe aanleiding bestaat, schoolverlaters meer van flexibele banen gebruik kunnen maken. Mogelijk is het probleem van langdurige werklozen dat zij ook voor banen met een flexibel contract nauwelijks in aanmerking komen.

\section{Figuur 4.3 Ontwikkeling van flexibele en zelfstandige arbeid}

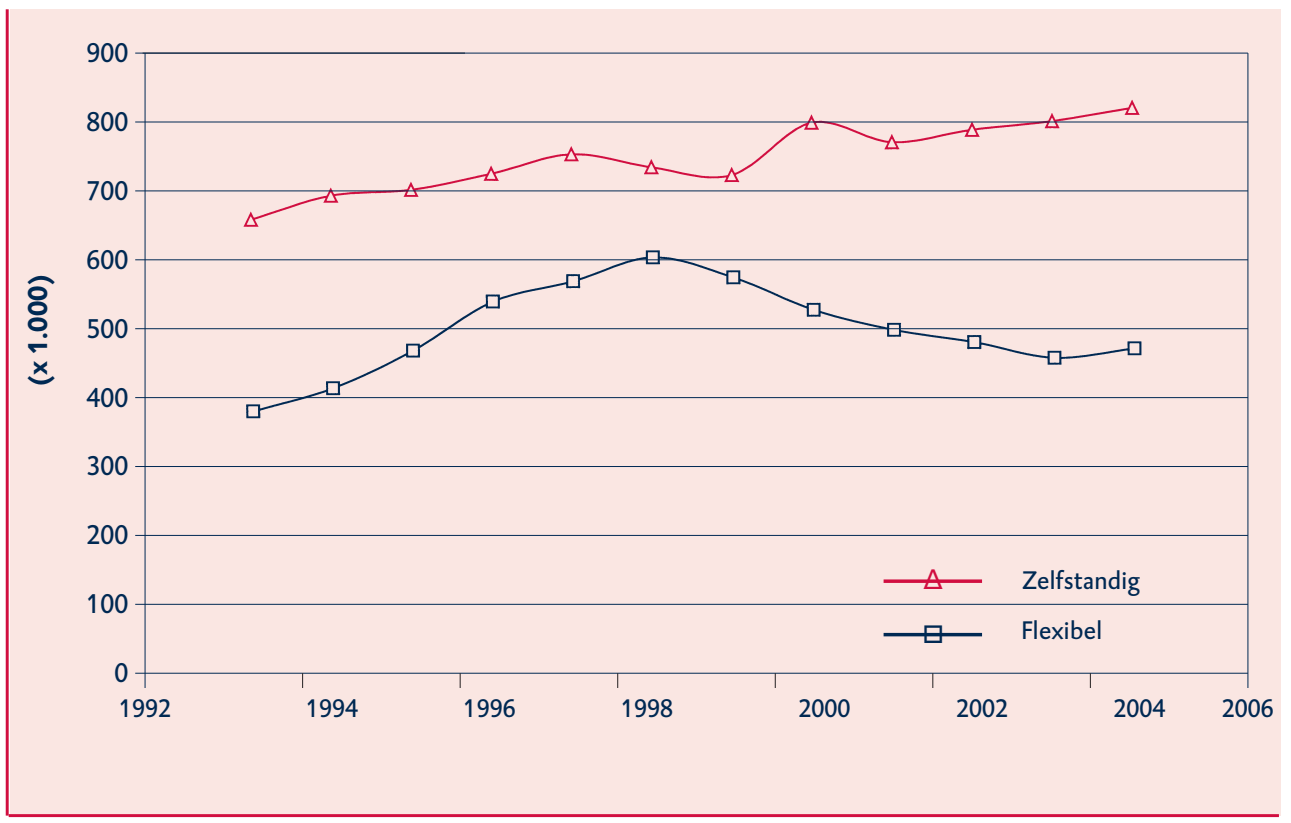

Bron: CBS Statline

\subsubsection{OUTSOURCING EN OFFSHORING}

Betrekkelijk nieuwe verschijnselen, die men als zeer vergaande vormen van interne flexibiliteit zou kunnen beschouwen, zijn outsourcing en offshoring. Outsourcing doet zich voor wanneer bedrijfsonderdelen worden afgesplitst en ingekocht van een ander bedrijf (bijv. door de bedrijfskantine niet meer met eigen personeel te laten werken maar cateringdiensten in te huren). Offshoring is het 
verplaatsen (door middel van outsourcing) van productieonderdelen over de landsgrenzen heen. Deze afsplitsingsprocessen zijn al decennialang gaande. Ze krijgen thans meer aandacht, omdat outsourcing vaker de vorm van offshoring krijgt, en omdat het niet langer alleen bij industriële ondernemingen plaatsvindt maar ook bij dienstverlenende bedrijven. Bij uitbesteding of outsourcing worden interne gezagsverhoudingen en controles vervangen door markttransacties en contracten. Dit raakt uiteraard ook de werknemers; bij een uitbesteding gaan ze soms over naar het bedrijf dat het uitbestede werk gaat doen. De afweging die bij uitbesteding wordt gemaakt hangt samen met transactiekosten. Het gebruik van de markt en het opstellen, uitvoeren en controleren van een opdrachtovereenkomst brengt transactiekosten met zich mee. Deze worden vergeleken met de transactiekosten verbonden aan het aannemen, motiveren en monitoren van het eigen personeel. Offshoring doet veel stof opwaaien in de media. Bij het CBS zijn geen nationale gegevens beschikbaar die een indruk kunnen geven van de omvang van dit fenomeen. De schattingen over de omvang worden meestal uitgevoerd door contractonderzoeksbureaus. Onderzoek van Deloitte en Touche, waarin gevraagd werd naar de voornemens van Nederlandse producenten om hun productie over de landsgrenzen te verplaatsen, leverde vrij hoge percentages op (Deloitte en Touche 2002-2004). Onderzoek van het SEO naar het schaarse beschikbare cijfermateriaal kwam op basis van gegevens over foreign direct investment tot meer geruststellende conclusies (Poort et al. 2004). Een artikel van A. Blinder (2006) wijst erop dat ICT de mogelijkheden van offshoring voor administratieve werkzaamheden vergroot. Het laatste oordeel is nog niet geveld. Er verdwijnen banen uit Nederland, maar er komen ook banen bij van buitenlandse bedrijven die in Nederland investeren.

\subsection{CONCLUSIES}

In dit hoofdstuk is gebleken dat op de Nederlandse arbeidsmarkt langdurige arbeidsrelaties nog steeds de norm zijn. Ook is echter duidelijk dat langdurige arbeidsrelaties niet behoeven te botsen met grote mobiliteit op de arbeidsmarkt. Op de interne arbeidsmarkt zijn belangrijke veranderingen merkbaar. Deze veranderingen worden voor een deel ingezet door externe omstandigheden, zoals de toepassing van nieuwe technologie, het opengaan van markten en de entree van nieuwe generaties jongeren op de arbeidsmarkt met andere wensen en voorkeuren ten aanzien van werk en vrije tijd. Ook veranderen bedrijfsstrategieën in de loop van de tijd om concurrenten op de productmarkten het hoofd te bieden. Daartoe zijn investeringen in menselijk kapitaal en kennis een noodzakelijke voorwaarde.

De psychologische binding van voorheen, met aandacht voor werknemersloyaliteit in ruil voor werkzekerheid, verschuift steeds meer in de richting van flexibele inzetbaarheid.

In dit hoofdstuk bleek ook dat arbeidsorganisaties veel meer dan vroeger gebruikmaken van een flexibele schil om hun kern van vaste medewerkers heen. Naast deze vorm van numerieke flexibiliteit, maken bedrijven ook gebruik van functio- 
nele flexibiliteit. Er worden meer eisen gesteld aan de inzetbaarheid (employability) van de werknemers. De eigen verantwoordelijkheid voor carrièreontwikkeling en de sterkere binding aan (de inhoud van) het werk nemen de plaats in van binding aan de organisatie. De verwachtingen tegenover het werk richten zich op de ontplooiingskansen die dat biedt. Die verwachtingen betreffen zowel de kansen op de interne als de externe arbeidsmarkt. De werknemer heeft hierbij zijn of haar eigen verantwoordelijkheid, maar de werkgever faciliteert de inzetbaarheid op de interne en de externe arbeidsmarkt.

Ten slotte, de vraag of de gemiddelde baanduur in de tijd genomen daalt, is relevant voor het arbeidsmarktbeleid. Van dit beleid mag verwacht worden dat het de risico's van baanmobiliteit beheersbaar houdt. Een arbeidsmarkt met een hoge baanmobiliteit stelt andere eisen dan een arbeidsmarkt waar de baan voor het leven nog een zekere realiteitswaarde heeft. Aangezien de verdeling van stabiele dienstverbanden duidelijk aan verandering onderhevig is, komen we op dit thema terug in hoofdstuk 7. 


\section{NOTEN}

Bij het schrijven van dit hoofdstuk is dankbaar gebruikgemaakt van de uitkomsten van een groot aantal gesprekken met personeelsmanagers van grote bedrijven en andere arbeidsorganisaties in Nederland. De gesprekspartners zijn vermeld in bijlage II bij dit rapport.

2 Deze paragraaf bouwt voort op enkele inzichten uit studie van Jelle Visser en Marc van der Meer over interne arbeidsmarkten (Visser en Van der Meer 2007).

3 De geslotenheid heeft de interne arbeidsmarkt gemeen met de 'beroepsgebonden arbeidsmarkt' voor een bepaalde beroepsgroep. Een beroepsbeoefenaar kan achtereenvolgens of tegelijkertijd bij verschillende organisaties tewerkgesteld zijn. Het gaat dan echter om externe mobiliteit die buiten het bestek van dit hoofdstuk valt. Wel zijn doktoren, verpleegsters, metselaars en timmerlieden mensen die, doordat hun deskundigheden niet bedrijfsgebonden zijn, betrekkelijk eenvoudig van werkplaats kunnen veranderen, en dus eerder geschikt zijn voor flexwerk, optreden als zzp'er e.d. (zaken die in par. 4.5. aan de orde komen).

4 De scholingsinstituten in de bouw staan dat overigens ook toe. Alle werknemers in de bouwnijverheid kunnen zich in het kader van hun employability laten omen bijscholen voor een baan buiten de bedrijfstak.

$5 \quad$ Men krijgt bijvoorbeeld de kantonrechtersformule 'mee' indien men snel zelf een baan vindt. Soms wordt bij herplaatsing het verschil in salaris nog voor een lange periode ( 4 jaar) aangepast.

6 Ferry Koster (2005) heeft dit argument in zijn proefschrift overigens gefalsificeerd, in teams werken vaste en tijdelijke medewerkers volgens hem uitstekend samen. 


\section{ARBEIDSMARKTFLEXIBILITEIT, VAN BUITEN NAAR BINNEN EN OMGEKEERD}

\section{$5.1 \quad$ INLEIDING}

Dit hoofdstuk handelt over groepen op de arbeidsmarkt, over hun positie en ervaringen met flexibiliteit en vooral mobiliteit. Voor sommige groepen blijkt het bezit van bepaalde kenmerken vaak samen te vallen met een meer dan gemiddeld percentage inactieven en/of uitkeringsgerechtigden. Zijn deze groepen omvangrijk, dan dreigt er een buitenrand in de arbeidsmarkt te ontstaan, bestaande uit groepen werknemers met een laag inkomen, die vaak wisselen van baan en van arbeidsmarktstatus. Eenmaal behorend tot die categorie wordt het moeilijk in het 'reguliere' deel van de arbeidsmarkt te komen. Naast het persoonlijke nadeel daarvan voor hun inkomen en ontwikkelingsmogelijkheden betekent dit voor betrokkenen een beroep op collectieve voorzieningen en de collectieve middelen. Een punt dat steeds nadrukkelijker aandacht vraagt, betreft de arbeidsmarktpositie en arbeidsmarktvooruitzichten van personen die - gedurende een periode in het arbeidsleven - verschillende taken proberen te combineren, waarvan de combinatie van arbeid en (kinder)zorg de belangrijkste is (WRR 2006). In dat rapport wordt in navolging van Schmid (2005) een zestal 'nieuwe risico's' benoemd, die vooral betrekking hebben op de bijzondere groepen die in dit hoofdstuk behandeld worden. Het gaat onder anderen om werknemers in het spitsuur van hun leven die arbeid en zorg of arbeid en opleiding moeten combineren, om laagopgeleiden en om oudere werknemers.

In dit hoofdstuk wordt een beeld geschetst van verschillende groepen op de arbeidsmarkt. Verschillen in mobiliteit, statusverandering, baanduur en inkomen worden vergeleken tussen jongeren en ouderen, tussen mannen en vrouwen, voltijders en deeltijders, tussen de boven- en onderkant van de inkomensverdeling en tussen autochtonen en allochtonen. Voorts wordt bezien welke groepen getroffen worden door baandestructie of baat hebben bij baancreatie. Ook wordt gekeken naar kenmerken van werknemers die niet van baan zijn gewisseld, maar op hun plek zijn blijven zitten.

\subsection{OMVANG VAN CATEGORIEËN OP DE ARBEIDSMARKT}

Van de ruim 16 miljoen personen in Nederland vormen 11 miljoen de beroepsgeschikte bevolking van $15-65$ jaar. Hun arbeidsmarktstatus wordt weergegeven in tabel 5.1.

In de leeftijd van 15 tot 30 jaar is bijna 60 procent (werknemer of zelfstandige) actief. Dat loopt op tot 75 procent tussen de 30 en 55 jaar, om vervolgens scherp te dalen. Die daling van de activiteit na 55 jaar gaat gepaard met een verdubbeling van het beroep op uitkeringen (+ 20 procentpunten), waarbij vooral het beroep op prepensioen vanaf $55+$ opvalt. 


\begin{tabular}{|l|r|r|r|r|r|r|r|} 
& Totaal & $\begin{array}{r}\text { Werk- } \\
\text { nemer }\end{array}$ & $\begin{array}{r}\text { Zelf- } \\
\text { standig }\end{array}$ & $\begin{array}{r}\text { Uit- } \\
\text { kering }\end{array}$ & $\begin{array}{r}\text { Pen- } \\
\text { sioen }\end{array}$ & $\begin{array}{r}\text { Scho- } \\
\text { lier }\end{array}$ & $\begin{array}{r}\text { In- } \\
\text { actief }\end{array}$ \\
& & & & & & & \\
& & & & & & & \\
15 - 29 jaar & 3.071 & $57 \%$ & $2 \%$ & $5 \%$ & $0 \%$ & $27 \%$ & $8 \%$ \\
30 - 54 jaar & 6.296 & $68 \%$ & $7 \%$ & $11 \%$ & $0 \%$ & $0 \%$ & $13 \%$ \\
$\mathbf{5 5}$ - 59 jaar & 954 & $41 \%$ & $6 \%$ & $19 \%$ & $13 \%$ & $0 \%$ & $20 \%$ \\
$\mathbf{6 0}-\mathbf{6 4}$ jaar & 770 & $8 \%$ & $3 \%$ & $20 \%$ & $48 \%$ & $0 \%$ & $19 \%$ \\
Totaal in \% & 11.055 & 6.538 & 624 & 1.170 & 515 & 849 & 1.395 \\
Personen (x 1000) & & $58 \%$ & $6 \%$ & $10 \%$ & $5 \%$ & $8 \%$ \\
\hline
\end{tabular}

Bron: CBS/SSB, bewerking WRR

Uit deze en verdere gegevens blijkt dat van de beroepsgeschikte bevolking 7,1 miljoen personen werken (nettoarbeidsparticipatie 64 procent), waarvan 4,7 miljoen in voltijd (d.w.z. 41 procent nettoarbeidsparticipatie) en de overigen (23 procent van de participatie) in deeltijd.

Van de resterende 4 miljoen niet-werkenden in de beroepsgeschikte bevolking hebben ruim 1,5 miljoen een sociale of pensioenuitkering, bijna 1 miljoen volgen onderwijs en bijna 1,5 miljoen, met name vrouwen, zijn anderszins inactief.

Figuur 5.1 brengt de verschillen in arbeidsmarktstatus naar leeftijd in beeld. Jongeren tot begin twintig behoren meestal - bezien vanuit de arbeidsmarkt - tot de groep inactieven.

\section{Figuur 5.1 Arbeidsmarktstatus naar leeftijd (2001)}

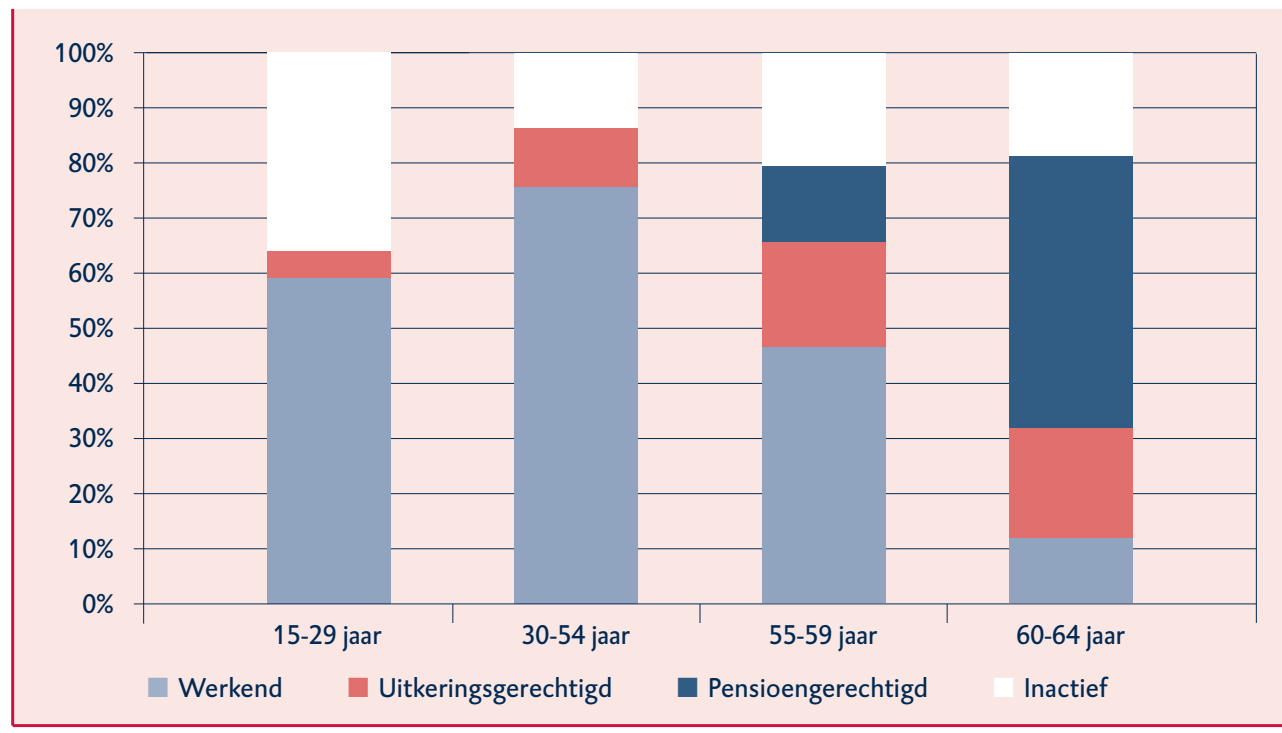

Bron: CBS/SBB, bewerking WRR 
Ze zitten op school of studeren. Rond de twintig treden ze toe tot de arbeidsmarkt en 'werkend' wordt dan de dominante status tot ongeveer de leeftijdsgroep van 55 jaar en ouder. Dan volgt een snelle toename van de toestand 'pensioen- en uitkeringsgerechtigd'. Duidelijk is dat binnen ieder van de leeftijdscategorieën de arbeidsmarktposities en arbeidsmarktmogelijkheden van personen verschillen.

\subsection{BAANDUUR NAAR INKOMEN, LEEFTIJD EN GESLACHT}

In de vorige hoofdstukken is al uitgebreid ingegaan op het belang van een zekere duur van een baan. Het ingroeien in een baan en het opdoen van ervaring, kennis van de werkomgeving, het learning-by-doing en de daarmee verbonden individuele productiviteitstoename en de daaraan gekoppelde inkomensstijging zijn daarbij de kernelementen. De eerstgenoemde onderdelen vergen tijd, dat wil zeggen voor het overgrote deel van de werknemers een aantal jaren eenzelfde baan. In tabel 5.2 worden, aan de hand van het SSB-bestand van het CBS, werknemers toegespitst op de baanduur bezien naar een aantal andere kenmerken: leeftijd, geslacht, voltijd/deeltijd en inkomen. Uit deze tabel komt een aantal saillante punten naar voren. Zo werken 2,5 van de 6,5 miljoen werknemers korter dan 3 jaar in de huidige baan, terwijl bijna 1,8 miljoen werknemers, bijna 30 procent van het totaal, al langer dan 10 jaar bij dezelfde werkgever zit. Vooral jeugdigen hebben, begrijpelijkerwijs, een korte baanduur.

Van de 2,8 miljoen vrouwen hebben maar 6 oo duizend, ruim 2 procent, een baanduur van langer dan 1o jaar, tegenover bijna 1,2 miljoen mannen, bijna 32 procent. Van deeltijders heeft de helft een baanduur korter dan 3 jaar. De samenloop van baanduur en met name leeftijd is bij jeugdige werknemers ook duidelijk zichtbaar in de cijfers over de inkomensverdeling. Een aantal van deze zaken is op zichzelf goed verklaarbaar. Zo staan jongeren aan het begin van hun loopbaan; zij hebben hun toekomst, qua werkervaring, productiviteitsstijging en inkomensontwikkeling nog voor zich. De verschillen in tabel 5.2 hebben echter meer oorzaken, die in het vervolg van dit hoofdstuk aan de orde komen.

\subsection{VORMEN VAN EXTERNE MOBILITEIT: VERSCHILLEN NAAR LEEFTIJD, INKOMEN EN GESLACHT}

Iedereen beweegt tijdens het werkzame leven op de arbeidsmarkt. Mensen treden toe, houden die betrekking en krijgen promotie, nemen of krijgen ontslag, vinden een andere baan, krijgen een uitkering of worden inactief en uiteindelijk gaat iedereen met pensioen. De belangrijkste bewegingen worden hierna behandeld.

\subsubsection{BAANWISSELINGEN}

\section{Baanwisseling naar leeftijd}

Figuur 5.2 toont het verschil tussen baanwisselaars, blijvers en werkenden naar leeftijd voor de periode 2002-2003. Weergegeven worden het relatieve aandeel van het aantal werkenden, het aantal blijvers en het aantal baanwisselaars per leef- 
Tabel 5.2 Baanduur van werknemers naar leeftijd, geslacht, voltijd/deeltijd en inkomen (2003)

\begin{tabular}{|c|c|c|c|c|c|}
\hline \multicolumn{6}{|c|}{ TOTAAL WERKNEMERS (in \% totaal) } \\
\hline & $<3$ jaar & $3-<10$ jaar & $>10$ jaar & Eindtotaal & in pers. \\
\hline $15-29$ jaar & $15 \%$ & $8 \%$ & $0 \%$ & $24 \%$ & 1.572 .310 \\
\hline $30-55$ jaar & $21 \%$ & $23 \%$ & $22 \%$ & $67 \%$ & 4.370 .780 \\
\hline $55-59$ jaar & $2 \%$ & $2 \%$ & $4 \%$ & $7 \%$ & 486.340 \\
\hline $60-64$ jaar & $1 \%$ & $0 \%$ & $1 \%$ & $2 \%$ & 99.960 \\
\hline Eindtotaal & $39 \%$ & $34 \%$ & $27 \%$ & $100 \%$ & \\
\hline & 2.531 .630 & $\begin{array}{r}2.232 .100 \\
\text { waarvan: }\end{array}$ & 1.765 .660 & & 6.529 .390 \\
\hline & $<3$ jaar & $3-<10$ jaar & $>10$ jaar & Eindtotaal & in pers. \\
\hline mannen & $34 \%$ & $35 \%$ & $31 \%$ & & 3.724 .500 \\
\hline vrouwen & $40 \%$ & $37 \%$ & $23 \%$ & & 2.804 .400 \\
\hline \multicolumn{6}{|c|}{ W.V. VOLTIJDERS } \\
\hline & $<3$ jaar & $3-<10$ jaar & $>10$ jaar & Eindtotaal & in pers. \\
\hline 15 - 29 jaar & $17 \%$ & $7 \%$ & $0 \%$ & $25 \%$ & 1.359 .760 \\
\hline $30-55$ jaar & $22 \%$ & $22 \%$ & $22 \%$ & $66 \%$ & 3.676 .030 \\
\hline 55 - 59 jaar & $1 \%$ & $2 \%$ & $4 \%$ & $8 \%$ & 427.100 \\
\hline $60-64$ jaar & $0 \%$ & $1 \%$ & $1 \%$ & $2 \%$ & 84.440 \\
\hline Eindtotaal & $40 \%$ & $32 \%$ & $28 \%$ & $100 \%$ & \\
\hline in pers. & 2.202 .890 & 1.801 .800 & 1.542 .640 & & 5.547 .330 \\
\hline \multicolumn{6}{|c|}{ W.V. DEELTIJDERS } \\
\hline & $<3$ jaar & $3-<10$ jaar & $>10$ jaar & Eindtotaal & in pers. \\
\hline $15-29$ jaar & $17 \%$ & $4 \%$ & $0 \%$ & $22 \%$ & 212.550 \\
\hline $30-55$ jaar & $31 \%$ & $22 \%$ & $18 \%$ & $71 \%$ & 694.750 \\
\hline 55 - 59 jaar & $2 \%$ & $2 \%$ & $2 \%$ & $6 \%$ & 59.240 \\
\hline 60 - 64 jaar & $0 \%$ & $1 \%$ & $1 \%$ & $2 \%$ & 15.520 \\
\hline Eindtotaal & $50 \%$ & $29 \%$ & $21 \%$ & $100 \%$ & \\
\hline in pers. & 490.250 & 286.730 & 205.080 & & 982.060 \\
\hline \multicolumn{6}{|c|}{ TOTAAL WERKNEMERS } \\
\hline \multicolumn{6}{|c|}{ in deciel 1 tot 4 (net boven minimuml. en lager) } \\
\hline & $<3$ jaar & $3-<10$ jaar & $>10$ jaar & Eindtotaal & in pers. \\
\hline 15 - 29 jaar & $57 \%$ & $32 \%$ & $32 \%$ & $48 \%$ & 756.550 \\
\hline $30-55$ jaar & $41 \%$ & $28 \%$ & $19 \%$ & $29 \%$ & 1.285 .010 \\
\hline $55-59$ jaar & $39 \%$ & $30 \%$ & $18 \%$ & $26 \%$ & 125.140 \\
\hline $60-64$ jaar & $40 \%$ & $39 \%$ & $23 \%$ & $34 \%$ & 33.830 \\
\hline Eindtotaal & $47 \%$ & $29 \%$ & $19 \%$ & $34 \%$ & \\
\hline in pers. & 1.204 .330 & 656.700 & 343.850 & & 2.204 .880 \\
\hline \multicolumn{6}{|c|}{ in deciel 8 tot 10 ( $120 \%$ modaal en hoger $)$} \\
\hline & $<3$ jaar & $3-<10$ jaar & $>10$ jaar & Eindtotaal & in pers. \\
\hline $15-29$ jaar & $7 \%$ & $15 \%$ & $15 \%$ & $10 \%$ & 161.520 \\
\hline $30-55$ jaar & $29 \%$ & $40 \%$ & $49 \%$ & $40 \%$ & 1.726 .840 \\
\hline 55 - 59 jaar & $37 \%$ & $44 \%$ & $55 \%$ & $48 \%$ & 234.890 \\
\hline $60-64$ jaar & $38 \%$ & $40 \%$ & $52 \%$ & $43 \%$ & 43.010 \\
\hline Eindtotaal & $21 \%$ & $34 \%$ & $49 \%$ & $33 \%$ & \\
\hline in pers. & 528.370 & 768.670 & 871.740 & & 2.166 .260 \\
\hline
\end{tabular}

Bron: CBS/SSB, bewerking WRR 
tijdsgroep. Uit deze figuur blijkt duidelijk dat baanwisseling vooral iets is voor de jongere leeftijdsgroepen. Jongeren tussen de 15 en de 24 jaar waren goed voor 39 procent van het totale aantal baanwisselingen in deze periode, en de groep jongeren tot 29 jaar zelfs voor meer dan de helft van het totale aantal. Jongeren hebben niet alleen een kortere baanduur omdat zij een kortere periode werkzaam zijn, maar ook omdat zij in die korte periode relatief ook nog eens vaak van baan wisselen (Van Leeuwe et al. 20o6). OSA-onderzoek laat zien dat jongeren niet alleen mobieler zijn dan ouderen, maar ook mobieler zijn wanneer ze worden vergeleken met de jongeren van een decennium geleden (Bekker et al. 2003).

Figuur 5.2 Leeftijdsverdeling totale beroepsbevolking versus baanwisselaars, naar leeftijd (als \% totaal)

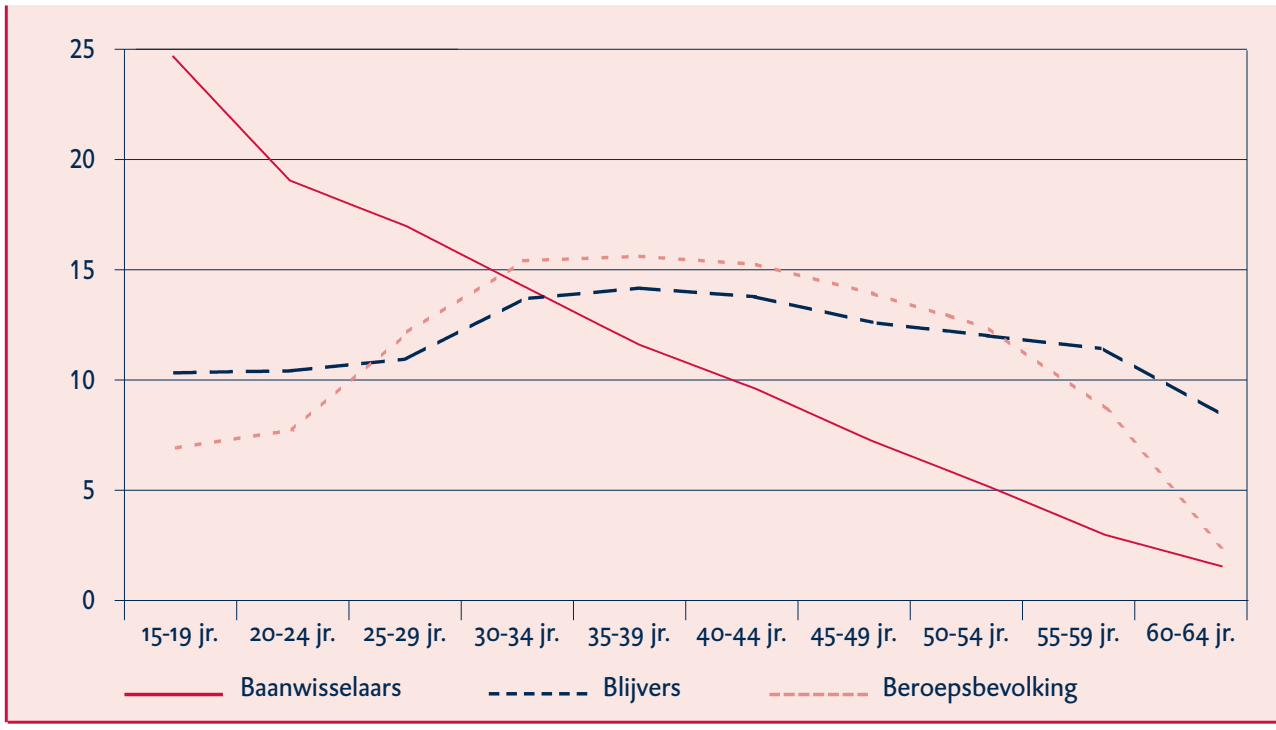

Bron: CBS/SBB, bewerking WRR

De hoge mobiliteit van jongeren heeft enerzijds te maken met zoeken naar de werkgever en de baan die bij hen past. Daarnaast is het feit dat jongeren vaker een contract voor bepaalde tijd hebben en daardoor gedwongen zijn meer van baan te wisselen, een verklarende factor (Bekker et al. 2005).

Voor veruit de meeste jongeren geldt dat zij of een kleine deeltijdbaan vervullen of een fulltimebaan hebben. Studenten (voor de hoger opgeleiden tot de leeftijd van ca. 25 jaar) hebben naast hun studie vaak nog een bijbaantje. Zo volgen in de leeftijdscategorie 20-24 jaar ruim 200.000 personen onderwijs. In die leeftijdscategorie bevinden zich ook circa 150.000 deeltijdbanen Waarschijnlijk zijn er nog meer kleine banen, omdat dit getal betrekking heeft op banen van 12 uur en langer (Steijn en Hofman 1999). Deze bijbaantjes kenmerken zich door flexibele en tijdelijke contracten. Het gaat hierbij om lager opgeleid werk, dat studenten 
een aantal uren per week (gemiddeld zo'n 12) naast hun studie hebben. Ook uitzendwerk is een typische aangelegenheid voor jongeren: bijna de helft van de uitzendkrachten is tussen de 15 en 24 jaar oud (Bekker et al. 2003).

Salverda (2003) laat zien dat tussen 1987 en 2002 een enorme verschuiving is opgetreden naar deeltijdarbeid. Het aantal fulltimers daalde met 28 procent, en hier stond een stijging van de parttime werkgelegenheid tegenover. Per hoofd van de jeugdige bevolking (15-24 jaar) verdubbelde deze van 17 tot 35 procent. Hiermee samenhangend steeg ook het aantal flexibele banen onder jongeren.

De klassieke groep 'werkende jongeren', eveneens in de leeftijd van 15 tot 24 jaar, zoekt werk om in hun onderhoud te voorzien. Ze zijn meestal op zoek naar een vaste, fulltimebaan. De leeftijdscategorie 15-24 omvat in totaal bijna 2 miljoen personen. Daarvan volgen 600.000 onderwijs, terwijl circa 700.000 een fulltimebaan hebben. Bijna 15 procent van deze leeftijdscategorie ontvangt een uitkering en nog eens 15 procent is inactief (geen werk/geen uitkering/niet schoolgaand). Voor een belangrijk deel gaat het hier om laagopgeleide (maximaal mavo of vbo) jongeren, zonder verdere en/of additionele opleidingen.

Van de 1,4 miljoen 'werkende jongeren' wisselen jaarlijks circa 160.00o van baan. Nog eens 50.000 per jaar verlaten de arbeidsmarkt met een uitkering, ongeveer 30.000 worden inactief, terwijl bijna 20.000 terugkeren in het onderwijs. Een tegengestelde beweging van bijna dezelfde omvang is zichtbaar bij toetreders in deze leeftijdscategorie van 15-24 jaar. Al met al blijkt bijna 40 procent van de groep werkende jongeren te bewegen tussen banen, maar ook tussen baan, uitkering en inactiviteit.

Het feit dat studenten beter gekwalificeerd en flexibeler inzetbaar zijn, zou erop kunnen duiden dat 'klassieke' werkende jongeren van de arbeidsmarkt worden verdrongen. Studenten geven aan dat het werk dat ze doen ook door een laagopgeleide gedaan zou kunnen worden. Hun werkgevers bevestigen dat, en geven te kennen dat zij vooral voor parttimebanen bewust kiezen voor de volgens hen meer flexibele, sneller ingewerkte en communicatief sterkere student. Functies voor fulltimers hebben de voorkeur van laagopgeleide jongeren, omdat deze groep meer uren per week beschikbaar is. Wanneer de inzet van studenten in flexibele, parttimebanen echter wordt omgezet in fulltime equivalents (fte's), kan worden geconcludeerd dat in de gezondheidszorg, detailhandel, horeca en industrie een aanzienlijk aantal fte's (gemiddeld zo'n 14.0oo) wordt ingevuld door studenten en niet door laagopgeleide jongeren (Steijn en Hofman 1999).

Jongeren zijn dus voor een significant deel verantwoordelijk voor de flexibiliteit op de Nederlandse arbeidsmarkt, doordat ze actief zijn in flexibele dienstverbanden, in deeltijdbanen én ook als zij in voltijd werken, nog vaak van baan en arbeidsmarktstatus wisselen (Salverda 2003). Het is niet zo dat de jongeren van tegenwoordig hun hele leven in flexibele en deeltijdcontracten willen werken. Wanneer zij weten wat ze zoeken in een baan en een werkgever, en als ze uiteindelijk de volgens hen optimale match te pakken hebben, is het hun bedoeling een vast contract voor een voltijdbaan te bemachtigen. 
Uit onderzoek blijkt wel dat flexibele arbeid een grote kans op doorstroming naar een vast contract biedt. Tijdelijk en flexibel werk wordt dan ook vaak een tussenstation. Twintig tot zelfs dertig procent van de mensen die nu werkzaam zijn op basis van een tijdelijk contract, heeft over een jaar een vaste baan. Dit geldt voor mensen met een contract voor bepaalde tijd, en ook voor uitzendkrachten. Van de werklozen die tijdelijk werk aannemen heeft na vijf jaar 8 o procent een vaste baan. Hadden zij dat tijdelijk werk niet aangenomen, dan zou dit percentage slechts 50 zijn. Het versnellingseffect van tijdelijk werk wordt ook wel 'het springplankeffect' of het steppingstone effect genoemd (SCP 2005; Zijl en Van Leeuwen 2004). Het steppingstone-effect geldt voor werknemers met bepaalde kenmerken en is dus niet evenredig verdeeld over de verschillende bevolkingsgroepen. Zo zijn het vooral jongeren die van de springplank gebruik kunnen maken. Verschillen tussen mannen en vrouwen zijn er niet of nauwelijks. Hoger opgeleiden hebben op voorhand meer kans op een vast contract wanneer ze tijdelijk werk aannemen dan lager opgeleiden en ook is een voorafgaande periode van werkloosheid van belang. Wanneer men langere tijd werkloos is geweest, neemt de kans op een vaste baan af. De wens tot en motivatie voor het vinden van vast werk (en het daardoor eerder accepteren van een tijdelijke baan als opstap of ingang voor vast werk) is ook een significante positieve factor voor het krijgen van een vaste baan (Zijl en Budil-Nadvorníková 2001).

\section{Baanwisselingen naar inkomen}

Baanwisselingen zijn niet alleen geconcentreerd bij jongeren. De tabellen en figuren in de rest van deze paragraaf betreffen andere factoren die ten minste even belangrijke zijn.

Tabel 5.3 Baanwisselaars naar leeftijd en inkomen (2002-2003)

\begin{tabular}{|c|c|c|c|c|c|c|c|}
\hline & & & & & Totaal & Totaal & \\
\hline & $15-29$ & $30-54$ & $55-59$ & $60-65$ & (in \%) & & $\begin{array}{r}\text { Als \% aantal } \\
\text { personen } \\
\text { in deciel }\end{array}$ \\
\hline DECIEL 1-3 & $63 \%$ & $28 \%$ & $30 \%$ & $59 \%$ & $48 \%$ & 421.520 & $28 \%$ \\
\hline DECIEL 4-7 & $33 \%$ & $42 \%$ & $29 \%$ & $17 \%$ & $36 \%$ & 320.030 & $11 \%$ \\
\hline DECIEL 8-10 & $4 \%$ & $31 \%$ & $40 \%$ & $24 \%$ & $16 \%$ & 140.690 & $6 \%$ \\
\hline Totaal Personen & 493.450 & 369.340 & 16.210 & 3.240 & & 882.240 & $13 \%$ \\
\hline Als $\%$ totale & & & & & & & \\
\hline Ift.groep & $31 \%$ & $8 \%$ & $3 \%$ & $3 \%$ & $14 \%$ & & \\
\hline
\end{tabular}

Bron: CBS/SSB, bewerking WRR

Tabel 5.3 geeft de verdeling van bijna 9oo.ooo baanwisselaars. Meer dan de helft behoort tot de jongste leeftijdscategorie, waarvan meer dan 60 procent in deciel 1 tot 3. Zoals hiervoor al is aangegeven, is dit begrijpelijk omdat de eerste baan in 
iemands loopbaan niet de beste match zal zijn. Jongeren wisselen relatief veel. De rest van de populatie wisselaars behoort hoofdzakelijk tot de categorie 30-6o jaar. Hier zien we dat juist de middengroepen qua inkomen (30-55 jaar) en de hoogste inkomensgroepen (55-60 jaar) de meeste baanwisselaars kennen, maar de verschillen zijn niet groot. Uit de laatste kolom blijkt dat van de totale populatie in deciel 1-3 bijna 30 procent van baan wisselt. Voor de hogere decielen loopt dit percentage baanwisselaars sterk terug.

Kenmerken die bepalend zijn voor het inkomen zijn leeftijd, etniciteit, flexibel werk en tijdelijke dienstverbanden. Een cumulatie in ongunstige zin van deze kenmerken betreft werknemers die actief zijn aan de onderkant van de arbeidsmarkt. Jongeren, allochtonen en laagopgeleiden zijn sterk oververtegenwoordigd aan de onderkant (De Beer 1996).

\section{Baanwisseling met inkomensvoor-en achteruitgangen naar leeftijd}

Wanneer vervolgens gekeken wordt naar inkomensvoor- en achteruitgangen van baanwisselaars en blijvers naar leeftijd (figuur 5.3), worden ook weer leeftijdseffecten zichtbaar. Tot de leeftijd van 25 jaar gaan de meeste baanwisselaars er wat inkomen betreft op vooruit, ondanks het feit dat deze leeftijdscategorie samen met ouderen het vaakst gedwongen mobiel is (SCP 2005). Dit heeft te maken met het zoekgedrag dat jongeren vertonen wanneer ze uit de schoolbanken op de arbeidsmarkt terechtkomen. Ze moeten als het ware hun plek op de arbeidsmarkt zien te vinden, waardoor ze vaker van baan wisselen. Men kan er van uitgaan dat men van baan wisselt totdat de optimale match tussen werknemer en baan is gevonden. Het is bij het verbeteren van die match niet gek dat ook het inkomen erop vooruitgaat.

Figuur 5.3 Inkomensveranderingen baanwisselaars naar leeftijd (2002-2003)

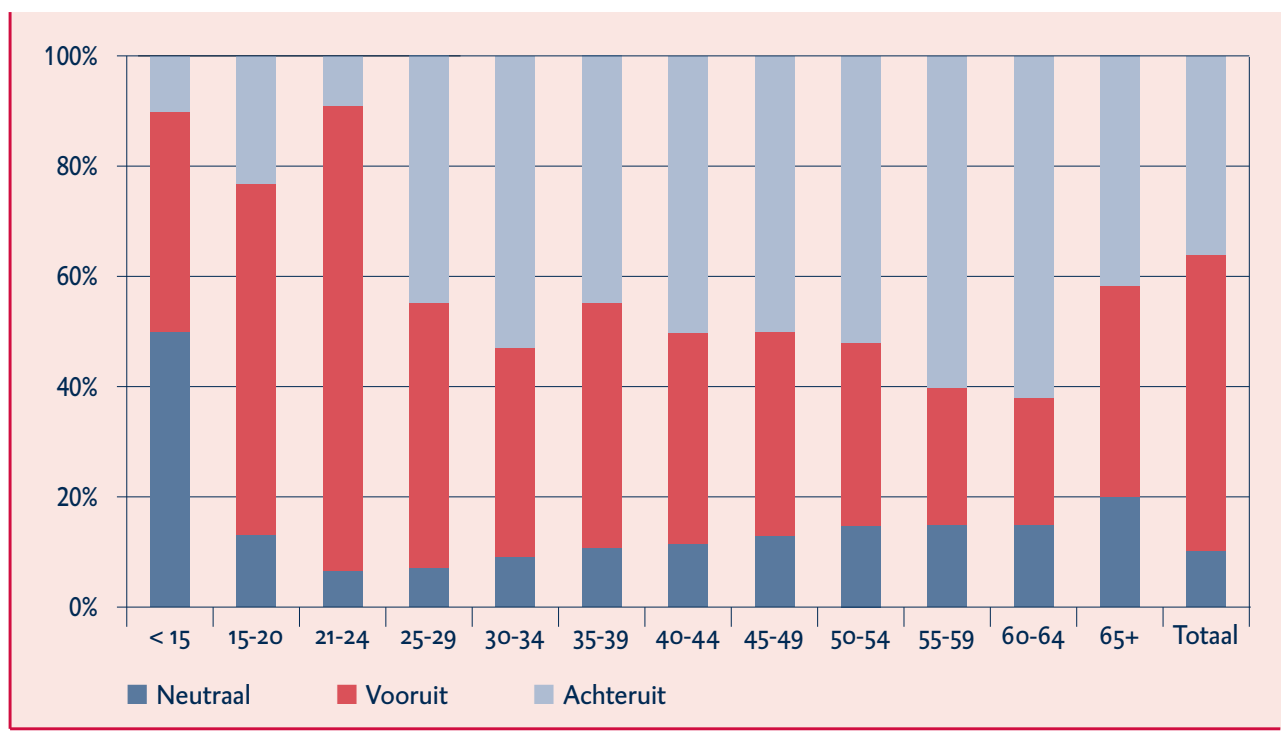

Bron: CBS/SBB, bewerking WRR 
Voor het leeftijdscohort 25 tot ongeveer 60 jaar geldt dat baanwisselaars er voor het overgrote deel op achteruitgaan. Er kan zelfs gezegd worden dat men er meer op achteruit, en minder op vooruitgaat wanneer de baanwisselaar ouder is. Bedacht moet worden dat dit betrekking heeft op 'ongewogen' cijfers. Uit tabel 5.3 blijkt dat 500.000 van de bijna 900.000 baanwisselaars jonger zijn dan 30 jaar. Als dit gegeven gecombineerd wordt met figuur 5.3, dan tekent zich de conclusie af dat de meeste baanwisselaars in ons land er qua inkomen op vooruitgaan. Dit wordt bevestigd door de totaalkolom in figuur 5.3. Overigens moet bedacht worden dat achter de baanwisselingen andere factoren schuil kunnen gaan, zoals een overgang van voltijd naar deeltijd. Daarnaast moet rekening worden gehouden met het feit dat het inkomen conjunctuurafhankelijk is, en dat er in 2002-2003 sprake was van een recessie.

\section{Baanwisseling bij mannen en vrouwen}

Het is plausibel dat er ook verschillen in mobiliteit bestaan tussen mannen en vrouwen. We weten dat mannen vaak fulltime werken, en dat vrouwen daarentegen vaak deeltijdbanen vervullen (Salverda 2003). Figuur 5.4 geeft aan dat een derde van de mannelijke baanwisselaars een inkomen heeft in deciel 1-3. Bij vrouwen behoort meer dan de helft van de baanwisselaars tot die laagste inkomenscategorieën. Slechts een derde van de vrouwen werkte in 2003 in een voltijdbaan. Van de mannen werkte 86 procent voltijd. Maar de helft van de vrouwen in de leeftijd van 20 tot 30 jaar werkt voltijds. Vanaf de leeftijd van 30 jaar gaan vrouwen, meestal door gezinsuitbreiding, meer in deeltijd werken.

\section{Figuur 5.4 Baanwisselaars mannen en vrouwen naar inkomen (2002-2003)}

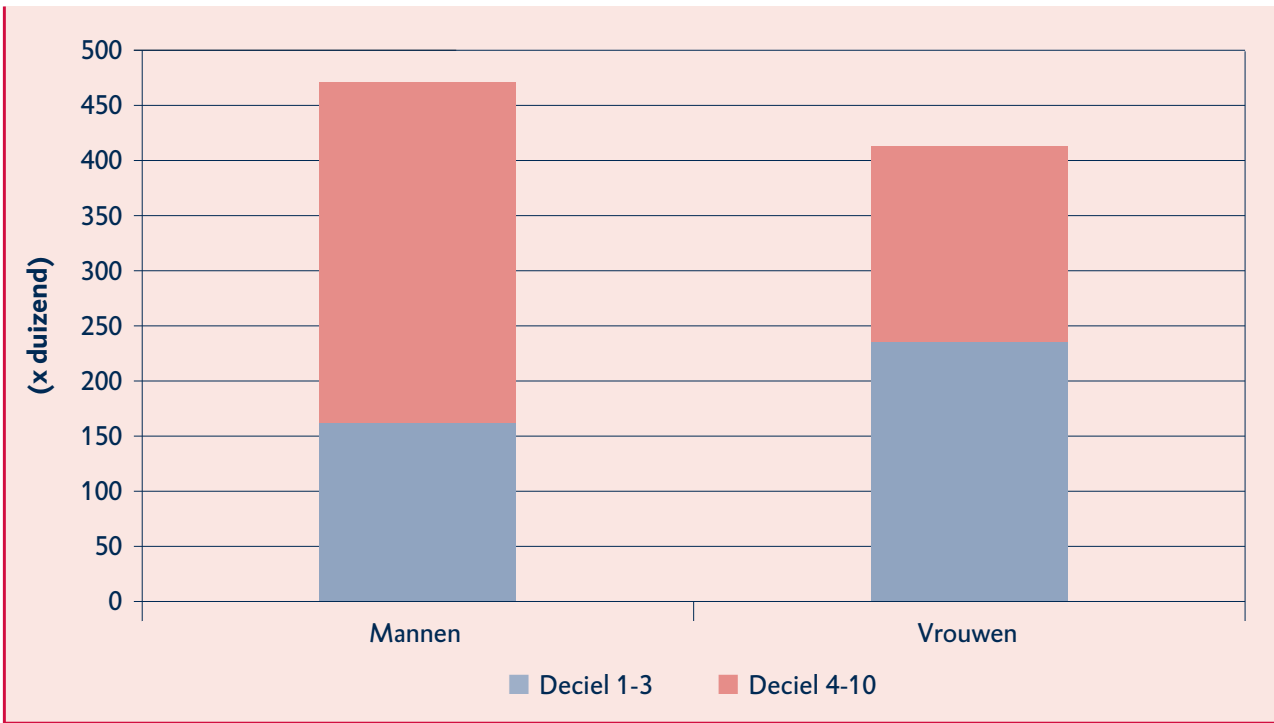

Bron: CBS/SBB, bewerking WRR 
Bij vrouwen cumuleren kortom verschillende factoren die op relatief frequente baanwisseling wijzen, meer dan bij mannen. Dat zij, gemiddeld, daadwerkelijk vaker van baan wisselen dan mannen is hiermee zeer waarschijnlijk (al ontbreken cijfers, dus 'directe' gegevens).

Concluderend kan gesteld worden dat jongeren, deeltijders, vrouwen en lagere inkomens relatief veel van baan wisselen. Als men kijkt naar het spiegelbeeld daarvan in de zin van langere en hogere baanduur, leeftijd en inkomen, dan blijkt dat naarmate de leeftijd stijgt, ook de baanduur en het inkomen stijgen.

\subsubsection{UITTREDEN UIT DE ARBEIDSMARKT}

Mobiliteit heeft niet alleen betrekking op de beweging van baan naar baan. Ieder jaar vertrekken ongeveer 500.00o personen van de arbeidsmarkt. De leeftijdsverdeling van deze uittreders én hun bestemming is als volgt: van de werknemers jonger dan 30 jaar keert een fors deel van de uittreders terug naar het onderwijs. Ruim 30 procent van de uittreders wordt inactief (d.w.z. heeft geen werk én geen eigen inkomen), vooral geconcentreerd in de leeftijdscategorieën 15-30 en 30-55 jaar.

\section{Figuur 5.5 Uittreders naar leeftijd en bestemming (2002-2003)}

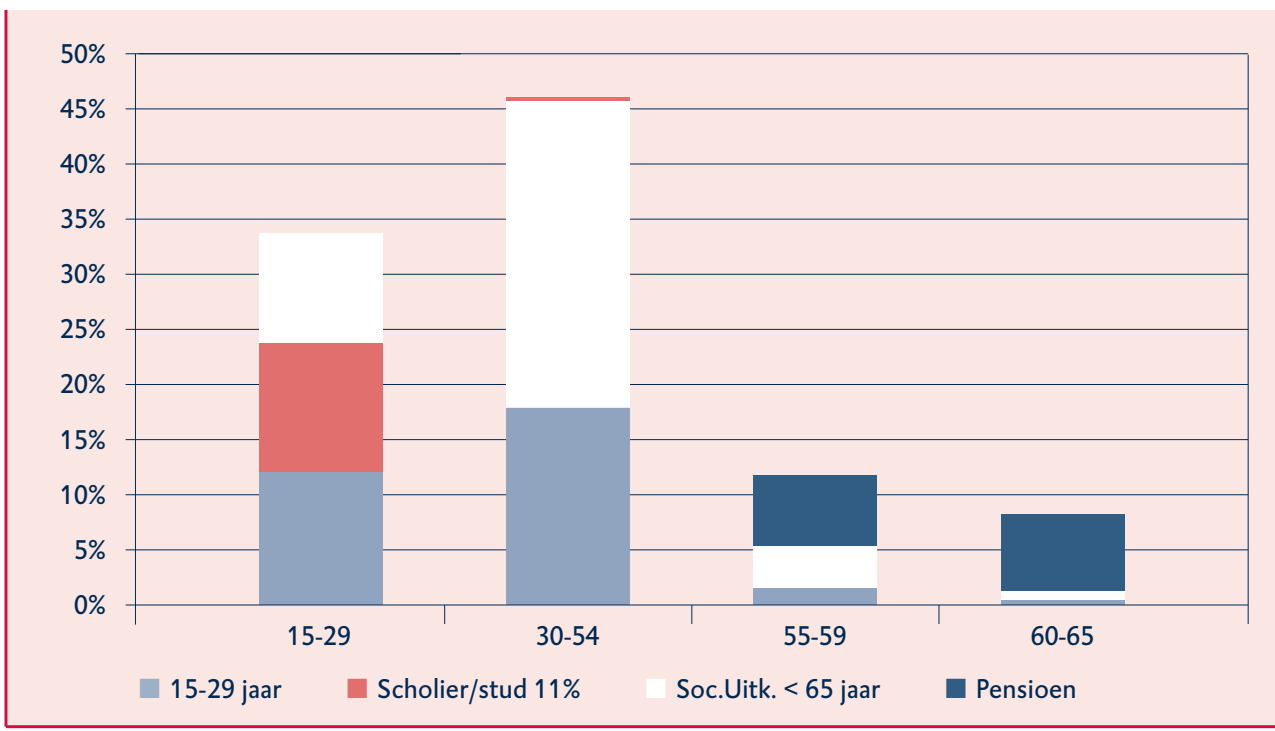

Bron: CBS/SBB, bewerking WRR

Bij die laatste gaat het vooral om uittredende vrouwen, naar verwachting met zorgtaken. Het merendeel van de uittreders in de leeftijd van 30-55 jaar doet een beroep op een inkomensvervangende regeling. Van de categorie $55+$ verdwijnt het merendeel naar pensioen- en vervroegde uitkeringsregelingen.

Uit gegevens van CBS/ssB blijkt dat bijna de helft van de uittreders behoort tot de laagste inkomenscategorieën. De helft van de uittreders die inactief worden en 
90 procent van de groep die terugkeert naar het onderwijs behoort tot de laagste inkomenscategorie. Bijna 75 procent van de middeninkomens doet bij uittreding een beroep op een inkomensvervangende regeling of gaat met pensioen. Bij de hoogste inkomens is dat ruim 60 procent.

Verder blijkt dat van de uittreders bijna 300.000 (65 procent) een baanduur hebben korter dan 3 jaar. Ook het overgrote deel van het beroep op inkomensvervangende regelingen vindt plaats bij die kortere baanduur (én lagere inkomens).

Daarentegen heeft 90 procent van de uittreders die met pensioen gaan een langere baanduur. Zij die terugkeren naar het onderwijs hebben een korte baanduur en een laag inkomen. Voor wat betreft de terugkeer naar de inactiviteit is het beeld gemengd. Uittreders, naar verwachting met name vrouwen met zorgtaken, treden uit iedere inkomenscategorie en iedere baanduurklasse.

Concluderend kan gesteld worden dat uittreden uit de arbeidsmarkt redelijk gelijk gespreid is over leeftijdscategorieën. Jongeren keren vooral terug naar het onderwijs, de oudste leeftijdscategorie verdwijnt in de pensioenregelingen. Tussen 30 en 55 jaar wordt vooral een beroep gedaan op inkomensvervangende regelingen. In alle leeftijdscategorieën verlaat in totaal bijna een derde van de uittreders de arbeidsmarkt naar inactiviteit. Aangenomen mag worden dat dit vrouwen met zorgtaken betreft.

\subsubsection{TOETREDEN TOT DE ARBEIDSMARKT}

Spiegelbeeldig aan de uittreders stromen er ieder jaar ook weer grote groepen naar de arbeidsmarkt. Het kan gaan om nieuwe toetreders, met name schoolverlaters die niet eerder gewerkt hebben, maar ook om herintreding van uittreders. Tabel 5.4 geeft de verdeling van de toetreders in 2003.

Het overgrote deel van de toetreders betreft schoolverlaters en inactieven. Met 80.000 is de terugkeer uit de inkomensvervangende regelingen iets groter dan de omvang van de uittreding naar die regelingen. Voor wat betreft toetreders vanuit

Tabel 5.4 Herkomst toetreders op de arbeidsmarkt (2003)

\begin{tabular}{|l|r|r|r|r|r|r|} 
& \multicolumn{2}{|c|}{ Mannen en vrouwen } & Mannen & & Vrouwen & (in \%) \\
& & & & (in \%) & & \\
Inactief & 144.390 & 33 & 54.380 & 26 & 90.010 & 39 \\
Onderwijs & 176.020 & 40 & 89.870 & 43 & 86.140 & 37 \\
Zelfstandig & 33.460 & 8 & 21.610 & 10 & 11.840 & 5 \\
Uitkering & 80.910 & 18 & 39.870 & 19 & 41.000 & 18 \\
Pensioen & 3.600 & 1 & 2.350 & 1 & 1.200 & 1 \\
Totaal & 438.380 & 100 & 208.080 & 100 & 230.190 & 100 \\
\hline
\end{tabular}

Bron: CBS/SSB, bewerking WRR 
het onderwijs zijn vrouwen- en mannenpopulaties nagenoeg even groot. Relatief veel vrouwen die eerder inactief waren treden toe. Figuur 5.6 geeft de leeftijdsverdeling van de toetreders. Ook hier blijkt weer de invloed van de schoolverlaters. Wat ook opvalt, is de grote groep toetreders uit de inactiviteit in de leeftijdsklasse 50-55 jaar. Herintredende vrouwen maken hiervan het merendeel uit. De terugkeer uit de inkomensvervangende regelingen is met 33 procent vanaf 30-55 jaar gelijk verdeeld.

\section{Figuur 5.6 Herkomst en leeftijdsverdeling toetreders op de arbeidsmarkt (2003)}

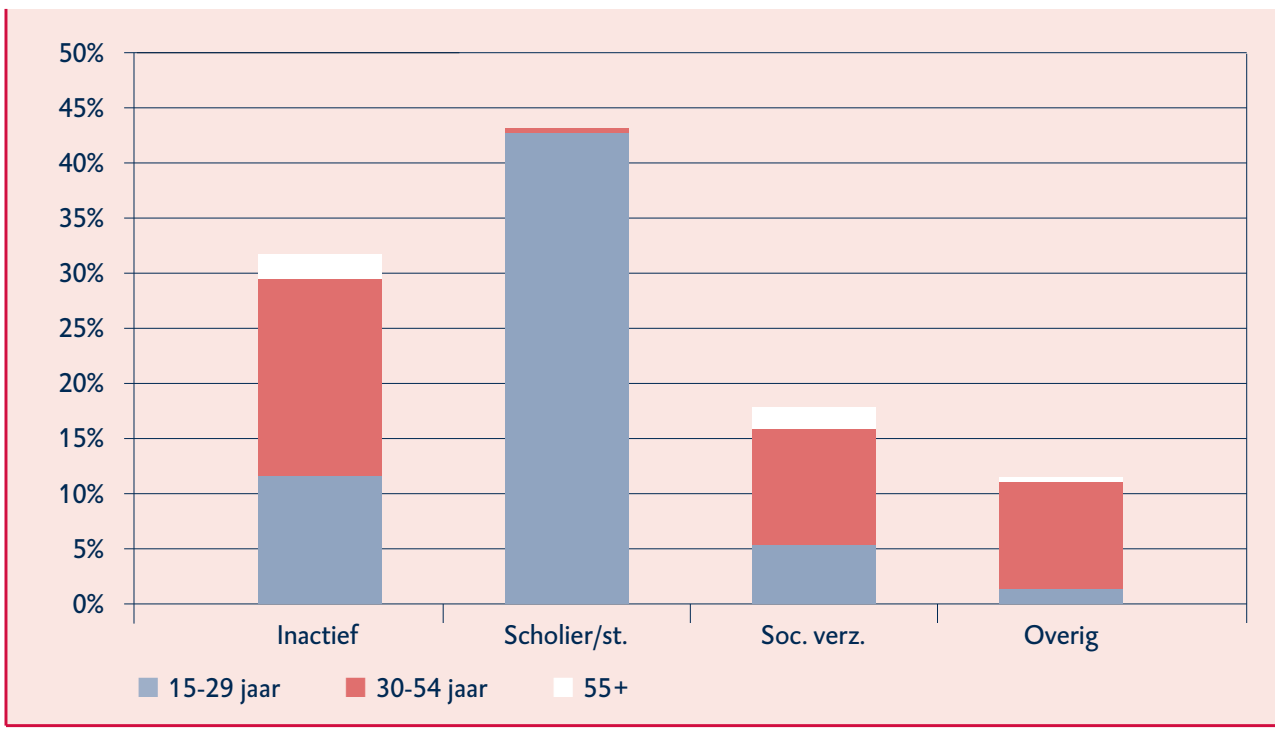

Bron: CBS/SBB, bewerking WRR

Geconstateerd kan worden dat ieder jaar een groot aantal personen erin slaagt actief te worden op de arbeidsmarkt. Wat opvalt is dat nog geen derde daarvan behoort tot de uitstroom uit de inkomensvervangende regelingen. Gezien de omvang van het beroep op die regelingen (zie ook par.5.1) kan dit als zorgelijk beschouwd worden, zeker afgezet tegen het succes en de omvang van de groepen die er wel in slagen een plaats op de arbeidsmarkt te verwerven.

\section{$5 \cdot 5$ SPECIFIEKE GROEPEN}

Veel van de verschillen in mobiliteit in de vorige paragrafen zijn uitsplitsbaar naar factoren als leeftijd, inkomen en baanduur. In deze paragraaf wordt een drietal groepen behandeld waarbij de negatieve aspecten van verschillende van die kenmerken cumuleren, te weten: vrouwen, allochtonen en oudere werknemers. 


\subsubsection{DE SPECIFIEKE POSITIE VAN VROUWEN}

Voor wat betreft het krijgen van een baan lijken vrouwen in het algemeen geen slechtere uitgangspositie te hebben dan (vergelijkbare) mannen. Wel verandert er veel tijdens de baan- c.q. levensloop, dat wel van wezenlijke invloed is op de carrièreontwikkeling. Dit kan voor een belangrijk deel verklaard worden uit het feit dat vrouwen nog altijd belast zijn met zorgtaken, met name de opvoeding van kinderen. Voor een belangrijk deel leidt dat tot een nog steeds omvangrijke afwezigheid van vrouwen op de arbeidsmarkt in juist die leeftijdsperioden, waarin op de arbeidsmarkt kansen tot loopbaanontwikkeling bestaan. Vrouwen die gedurende de zorg voor kinderen wel blijven werken doen dit in het algemeen in deeltijd. Van de vrouwen in de beroepsgeschikte bevolking werken er circa I miljoen minder dan van de mannen ( $3 \mathrm{om} 4 \mathrm{mln}$.). Tabel 5.5 geeft de verdeling van vrouwen over huishouden en de arbeidsdeelname. Zo'n 3,5 miljoen vrouwen in de leeftijd tussen de 15-65 jaar vormen samen met een partner een huishouding.

Tabel 5.5 Verdeling vrouwen over typen huishoudens naar voltijdse en deeltijdse arbeidsinkomens

\begin{tabular}{|l|r|r|r|r|r|r|r|} 
& Totaal & $\mathbf{1}$ vol & 1 deel & 2 vol & $\begin{array}{r}\text { 1 vol } \\
\mathbf{1} \text { deel }\end{array}$ & 2 deel & geen \\
Kind & & & & \multicolumn{2}{|c|}{$(\times 1000$ vrouwen $)$} & & \\
$<\mathbf{1 8 ~ j r}$ & 1.686 & 599 & 72 & 101 & 748 & 94 & 71 \\
$\geq \mathbf{1 8} \mathbf{~ j r}$ & 378 & 138 & 31 & 27 & 126 & 14 & 42 \\
Geen & 1.454 & 310 & 109 & 353 & 391 & 57 & 234 \\
Totaal & 3.518 & 1.047 & 212 & 481 & 1.265 & 165 & 347 \\
\hline
\end{tabular}

Bron: CBS STATLINE

Van de samenwonende vrouwen werkt bij meer dan 1 miljoen gevallen maar één partner, meestal de man. In 200.0oo gevallen wordt alleen parttime gewerkt. Bij 480.0oo huishoudingen werken beide partners voltijd, overwegend in paren zonder kinderen. Zijn er kinderen jonger dan 18 jaar, dan wordt in 1,2 miljoen paren fulltime én parttime gewerkt. Parttime vrijwel altijd door vrouwen. Van de 3,5 miljoen vrouwen die samenwonen, werken nauwelijks 500.0oo voltijd (tegenover 380.000 van de 790.000 alleenstaande vrouwen).

Internationaal gezien is Nederland de koploper op het gebied van deeltijdarbeid. Het aandeel deeltijdbanen in de totale werkgelegenheid is van 40 procent in 1995 gestegen tot 46 procent in 2003 ( $\mathrm{CPB} 2004$ ). In sectoren waar deeltijdwerk meer regel dan uitzondering is, zoals de zorg- en welzijnssector en het onderwijs, werken dan ook de meeste vrouwen (Bekker et al. 2003). 
Figuur 5.7 Wekelijkse arbeidsduur vrouwen in 2004, als percentage van leeftijdscategorie

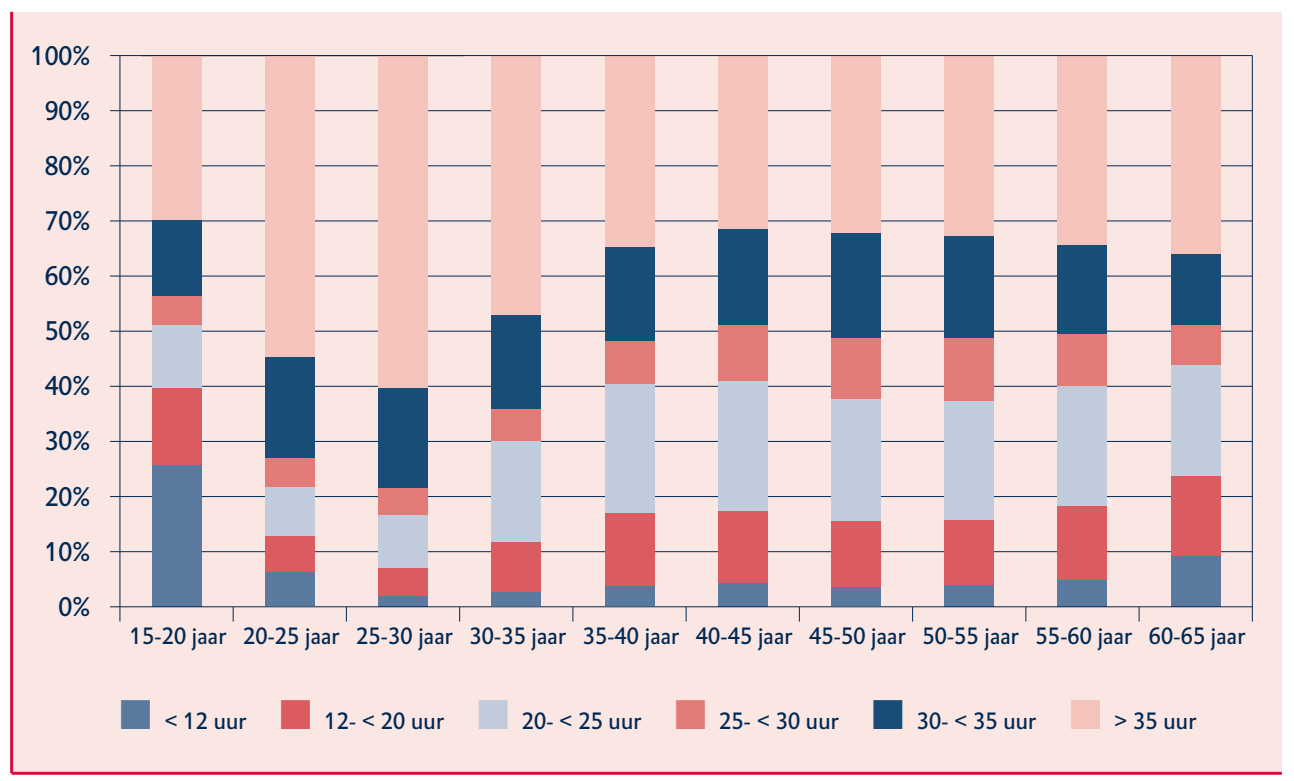

Bron: CBS/SBB, bewerking WRR

Een oorzaak van de populariteit van deeltijdwerk in Nederland is dan ook dat vrouwen de opvoeding van kinderen vaak op deze manier kunnen combineren (DNB 2005). Vrouwen werken over het algemeen voltijds tot de (eventuele) geboorte van een eerste kind. Figuur 5.7 laat zien dat het aantal vrouwen dat voltijd werkt vanaf 30 jaar terugloopt. Tegelijkertijd groeit vanaf die leeftijd het aantal vrouwen dat werkt in deeltijdbanen van 12 tot 25 uur per week. Het aantal gewerkte uren per week wordt bij het krijgen van het eerste kind dus meestal naar beneden bijgesteld. Uittreding is, anders dan enkele decennia geleden, allang geen regel meer. Het percentage vrouwen uit oudere generaties dat bij het krijgen van het eerste kind de arbeidsmarkt verliet was stukken hoger. Dit geldt voor elk opleidingsniveau (zie figuur 5.8). Hoewel voor elk opleidingsniveau geldt dat men, na de geboorte van het eerste kind, vaker blijft werken dan een aantal decennia geleden, zijn er wel verschillen tussen opleidingsniveaus. Vooral veel laagopgeleide vrouwen verlaten de arbeidsmarkt, terwijl hoogopgeleide vrouwen in deeltijd gaan werken (DNB 2005; Vlasblom en Schippers 2004). Dit verschil in uittreding tussen hoog- en laagopgeleide vrouwen kan samenhangen met een kosten-batenafweging. Voor hoger opgeleiden is de prijs om te stoppen met werken hoog. Door hun hogere loon is de opbrengst van werken relatief hoog. Voor laagopgeleiden geldt dit niet. Voor wie de arbeidsmarkt heeft verlaten is terugkeer niet altijd even gemakkelijk. Het vinden van een baan is namelijk ook afhankelijk van eerdere werkervaring. Dit wordt ook wel de 'mommy track' genoemd (Lommerud en Vagstad 200o). Vaak wordt daarom aanbevolen het voor (laagopgeleide) vrouwen makkelijker te maken om een binding met de arbeidsmarkt te behouden in de vorm van een (kleine) deeltijdbaan. 
Figuur 5.8 Werkende vrouwen voor en na geboorte eerste kind, naar opleidingsniveau (2003)

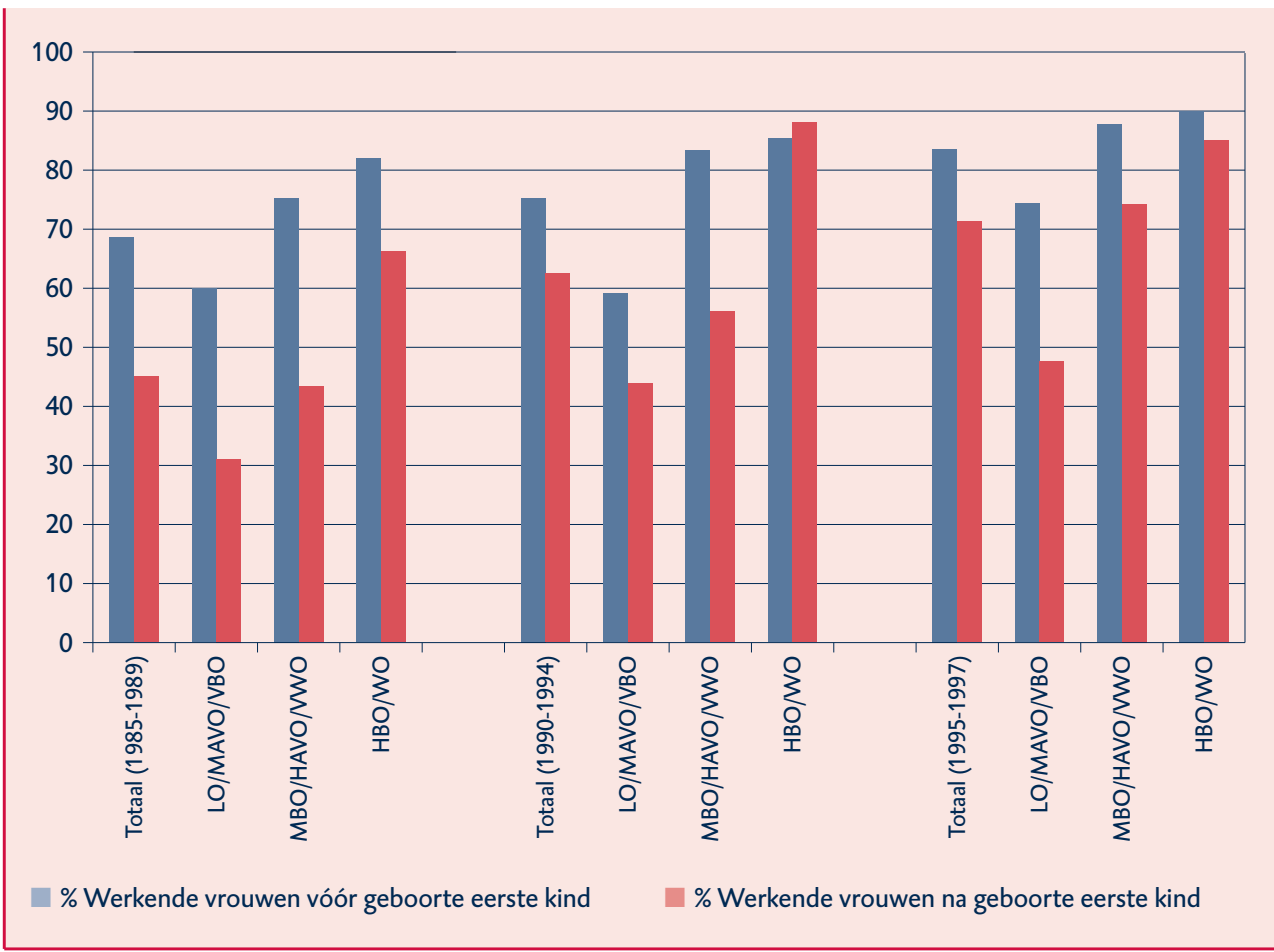

Bron: CBS/STATLINE

De vraag is echter of de uittreding of verminderde participatie van vrouwen vrijwillig is, of het gevolg is van (on)mogelijkheden om kinderen en werk te combineren. De uitkomsten van een onderzoek over het jaar 1998 van de Europese Stichting tot verbetering van levens- en arbeidsomstandigheden (2001) naar geslacht, werkgelegenheid en voorkeuren voor werktijden in Europa laten zien dat vrouwen met jonge kinderen een deeltijdbaan prefereren. Dit geldt voor alle opleidingsniveaus. De voorkeur voor een deeltijdbaan bij het krijgen van kinderen is tijdelijk en niet voor onbepaalde tijd. Moeders van oudere kinderen verkiezen een langere werkweek (Europese Stichting 2001).

\subsubsection{AUTOCHTOON VERSUS ALLOCHTOON}

In 2004 heeft 41 procent van de niet-westerse allochtonen tussen de 15 en 64 jaar een stabiele arbeidsmarktpositie (hier gedefinieerd als een vaste baan of een onderneming die langer dan 1 jaar bestaat). Voor de groep autochtonen ligt dit percentage hoger: hier heeft 61 procent een stabiele arbeidsmarktpositie (SCP 2005a). Uit figuur 5.9 blijkt dat allochtonen vaker van baan wisselen dan het gemiddelde van 12,4 procent. Vooral bij Marokkanen, Antillianen en overige nietwesterse werknemers is het percentage hoog; Surinamers en Turken zitten iets lager, maar nog steeds boven het nationale gemiddelde. 
Niet-westerse allochtonen hebben minder vaak dan autochtonen een vast dienstverband. Bijzonder hierbij is dat, hoewel bij autochtonen geldt dat mannen vaker een vast contract hebben dan vrouwen, het tegenovergestelde het geval is als het gaat om allochtonen (SCP 2005a). Voor allochtone jongeren geldt dat ze minder vaak in een voltijdbaan werken, minder vaak een vaste aanstelling hebben en minder vaak werkzaam zijn in een tijdelijke baan met uitzicht op een vaste aanstelling in vergelijking met autochtone jongeren (Van Ours et al. 2002).

Figuur 5.9 Baanwisselaars naar etniciteit als \% van herkomstgroep, 2002-2003

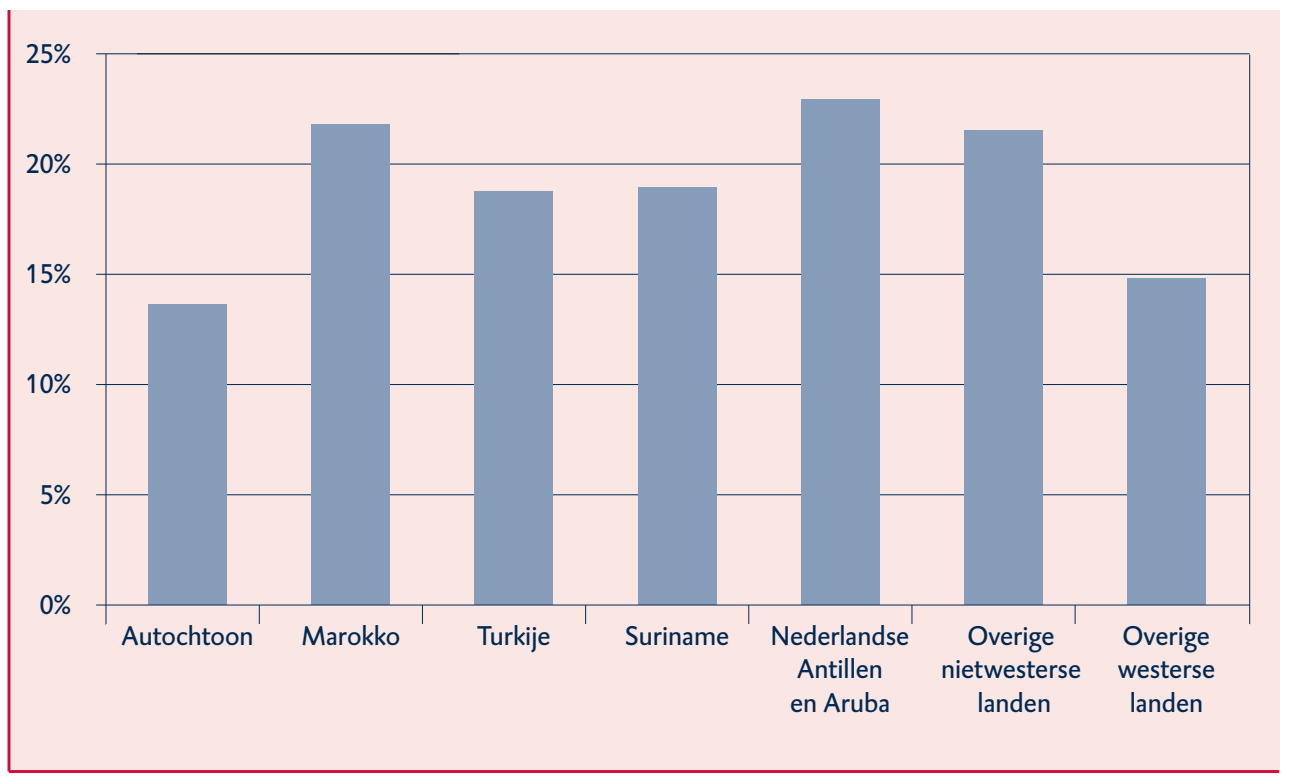

Bron: CBS/SBB, bewerking WRR

Sinds 1994 is de gemiddelde positie van allochtonen op de arbeidsmarkt verbeterd (SCP 2005a). Het aandeel allochtonen met een stabiele arbeidsmarktpositie was toen slechts 31 procent. De toename (tot 41 procent) in de daaropvolgende 10 jaar is te verklaren door een gestegen arbeidsparticipatie en ook door een toename in het aantal zelfstandige ondernemers. Het is echter niet zo dat er sprake is van een groter aandeel niet-westerse allochtonen met een vast dienstverband. Dit bleef tussen 1994 en 2004 constant; de stijging in de werkgelegenheid voor allochtonen aan het eind van de jaren negentig is grotendeels te verklaren door tijdelijke banen (SCP 2005a).

De verschillen tussen allochtonen en autochtonen kunnen voor het overgrote deel worden toegeschreven aan verschillen in opleidingsniveau en sociaal-economische achtergronden. Toch verdwijnen de verschillen in kansen op de arbeidsmarkt niet volledig wanneer men corrigeert voor de individuele kenmerken. Ook het verschil in zoekgedrag en de manier waarop men zich op een baan oriënteert zijn waarschijnlijk redenen voor de genoemde verschillen tussen de twee groe- 
pen. In hoeverre discriminatie ook een rol speelt bij het verklaren van de verschillen, is niet eenduidig aan te geven. Werkgevers schatten de arbeidsinzet van allochtonen lager in en brengen een zekere mate van differentiatie aan in de voorkeur van allochtonen groepen (SCP 2006).

\subsubsection{MOBILITEIT VAN OUDEREN}

Al eerder is aangegeven dat mobiliteit scheef over leeftijden verdeeld is. Twintigers zijn dynamisch en kennen veel loopbaanveranderingen. Dertigers kennen veelal een stabiel patroon, en uiteindelijk is op dezelfde plek blijven zitten dominant voor de middelbare leeftijd. Oudere leeftijdsgroepen worden noch door baanwisseling noch door een hoog percentage werkenden gekenmerkt. Vooral vanaf 50-54 jaar daalt de mobiliteit significant. Slechts vijf procent van het totaal aantal baanwisselingen wordt in de leeftijdscategorie 50+ gevonden. Veel ouderen zijn inactief en/of uitkeringsgerechtigd. Daarnaast ligt het percentage ouderen dat vrijwillig vertrekt op zo'n vijf procent (bij jongeren is dat 20 procent) (Gielen en Van Ours 2006). Bovendien werft slechts één op de vijf organisaties oudere werknemers. Ouderen worden, samen met allochtonen, het minst gevraagd en bij economisch minder goede tijden verwacht men zelfs dat ouderen plaatsmaken voor jongere werknemers (Van Dalen en Henkens 2003).

Het effect van baancreatie en -destructie pakt totaal anders uit voor de verschillende leeftijdsgroepen op de arbeidsmarkt (Van Leeuwe et al. 2006). Figuur 5.10 laat de leeftijdseffecten zien van baandestructie voor jongeren (tot 24 jaar), middelbare leeftijd (24-49) en oudere werknemers (50+).

\section{Figuur 5.10 Baandestructie en de bestemming van overbodige werknemers naar leeftijd}

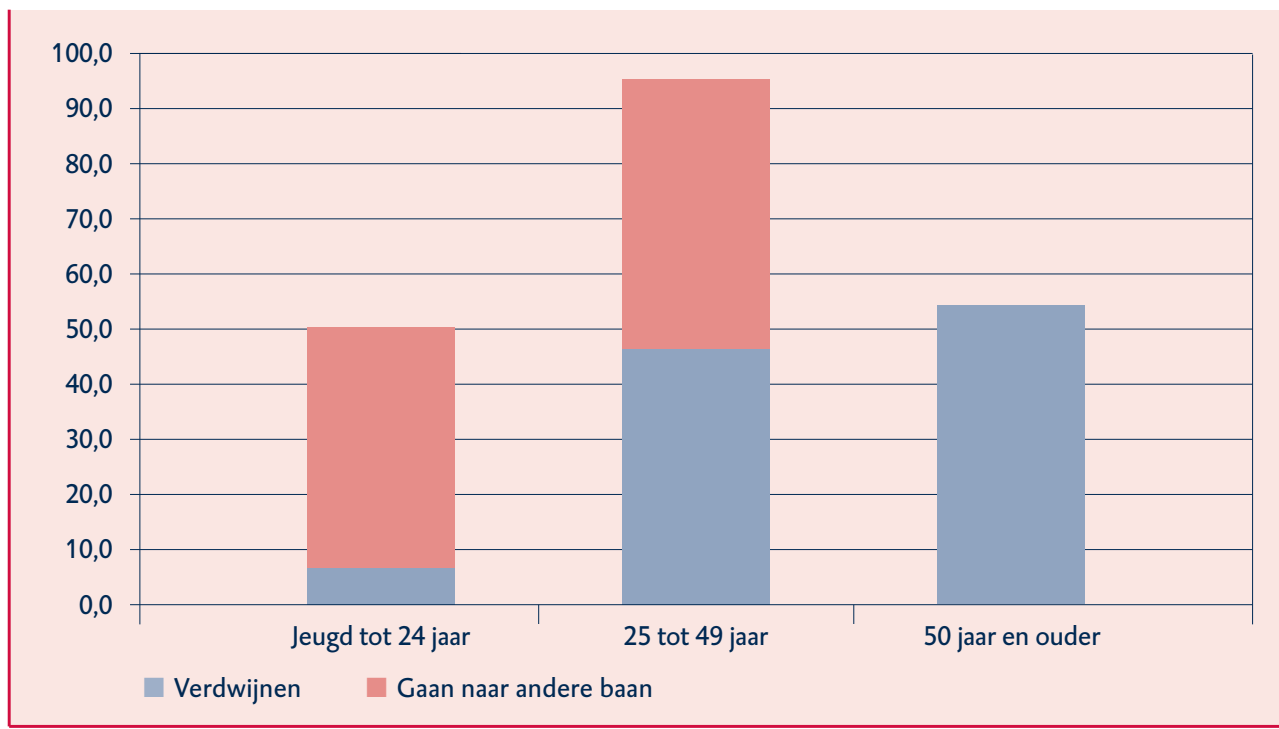

Bron: CBS/SBB, bewerking WRR 
Werknemers wier baan wordt opgeheven hebben twee mogelijke bestemmingen: of ze stappen over naar een andere baan of ze komen in een uitkeringssituatie terecht (gemakshalve noemen we dit 'verlaten van de arbeidsmarkt'). De vernietigde banen werden bezet door personen van wie aan de hand van het SsB de leeftijd is bepaald én hun arbeidsmarktstatus: andere baan of buiten de arbeidsmarkt. Van die twee bestemmingen is de (procentuele) verdeling naar leeftijd berekend. In figuur 5.10 zijn per leeftijdscategorie de twee verdelingen gecumuleerd. De figuur is zo geconstrueerd dat de twee bestemmingen ('andere baan' en 'verlaten van de arbeidsmarkt') over de drie leeftijdsgroepen elk optellen tot 1oo procent. Dit betekent dat de stukken van de staven in het diagram die dezelfde kleur hebben, samen 100 procent bedragen.

Zoals te verwachten valt is er een evident verschil tussen de jongste en de oudste leeftijdsgroep. Jongeren die hun baan kwijtraken stappen voor de overgrote meerderheid over naar een andere baan, terwijl de oudste leeftijdsgroep grotendeels de arbeidsmarkt verlaat. Voor de middelbare leeftijdsgroep zijn de beide bestemming meer gelijkmatig verdeeld.

In figuur 5.11 is eenzelfde - maar spiegelbeeldige - benadering toegepast voor baancreatie aan de hand van toetreden tot de arbeidsmarkt dan wel komend van een andere baan. Wanneer de nieuwe banen worden opgevuld door jeugdige werknemers, dan zijn die voor het grootste deel afkomstig van buiten de arbeidsmarkt (schoolverlaters bijvoorbeeld). Bij de oudste leeftijdsgroep komt er nauwelijks iemand van buiten de arbeidsmarkt. Oudere werknemers die eenmaal de arbeidsmarkt hebben verlaten, zijn minder dan de andere leeftijdsgroepen betrokken bij het opvullen van de nieuwe banen. In de middelbare leeftijdscategorie komen de twee afkomstmogelijkheden voor, zij het dat 'komende van een andere baan' wat vaker te zien is dan 'komende van buiten de arbeidsmarkt' (bijvoorbeeld herintreders). Toch werken oudere werknemers steeds meer tot op hogere leeftijd door. De participatie van 55- tot 64-jarigen is van 1996 tot 2005 verdubbeld, terwijl het aantal personen in de leeftijd van 55- tot 64-jarigen in die periode slechts met een derde is toegenomen. Door de vergrijzing van de beroepsbevolking zal de noodzaak tot mobiliteit ook voor oudere werknemers toenemen.

In de regel kunnen oudere werknemers hun loopbaan voortzetten bij de werkgever waar men al langer een arbeidsrelatie mee heeft. Er zijn echter weinig bedrijven meer waar van tijd tot tijd als gevolg van veranderende markt- of productieomstandigheden geen noodzaak tot aanpassingen in het personeelsbestand nodig worden geacht. Waar met ontslag bedreigde oudere werknemers in het verleden gebruik konden maken van regelingen voor vervroegde uittreding, wordt bij het afsnijden van deze uittreedroutes verwacht dat zij omzien naar ander werk. Deze werknemers zijn gedwongen een nieuwe stap in hun loopbaan te zetten en dat levert thans meer problemen op dan voor jongere werknemers. 
Figuur 5.11 Baancreatie en de afkomst van de nieuwe werknemers naar leeftijd

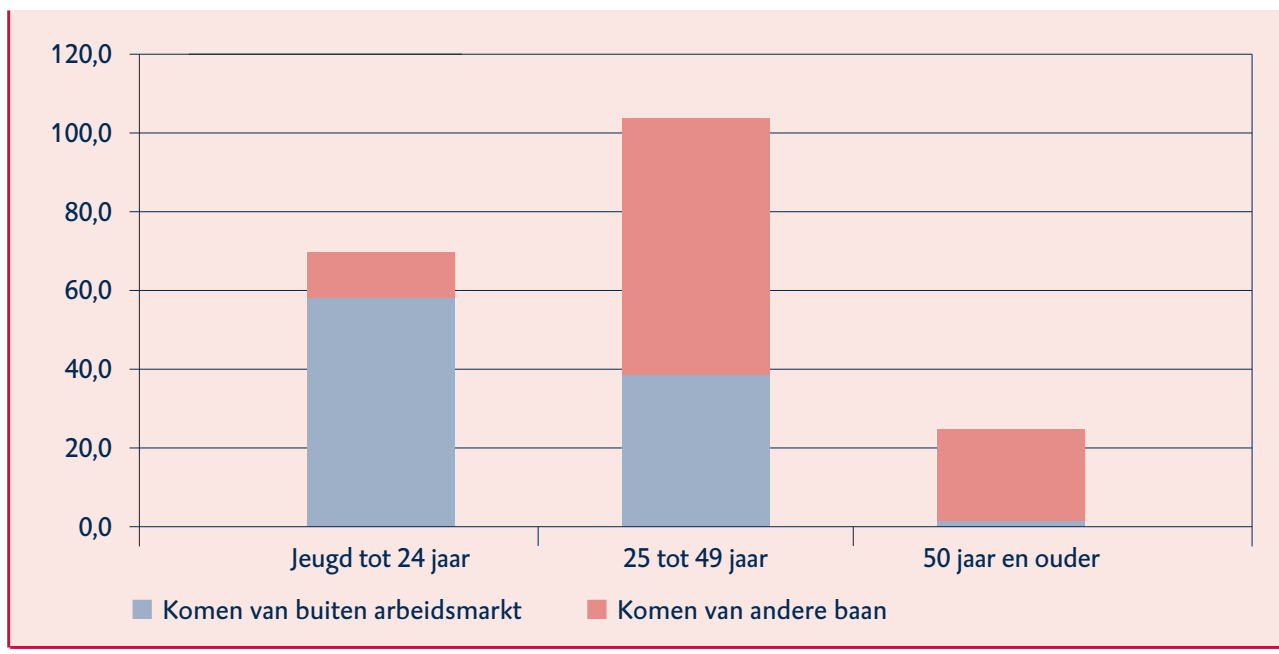

Bron: CBS/SBB, bewerking WRR

De uitstroom van oudere werknemers uit een uitkeringssituatie naar werk is gering. Voor een deel ligt dat aan de relatieve aantrekkelijkheid van die uitkeringen. Voor een deel ligt dat ook aan het feit dat werkgevers voor het vervullen van vacatures bij voorkeur werven onder jongeren. Werknemers die aan de tweede helft van hun loopbaan zijn begonnen hebben al wat meer moeite om van baan te wisselen, en oudere werknemers hebben ronduit grote moeilijkheden om nog van baan te wisselen (Kerhofs 2001). De vraag naar oudere werknemers kan zwak zijn, omdat veel oudere werknemers lange tijd in hun ontwikkeling hebben stilgestaan. Er is weinig geïnvesteerd in hun arbeidsvaardigheden en zij hebben zelf weinig gedaan om voorbereid te zijn op mogelijke wendingen in hun loopbaan. Daarnaast zijn de gezondheidsrisico's voor oudere werknemers groot. Dat houdt voor bedrijven financiële risico's in.

Ook het bestaan van interne arbeidsmarkten speelt een rol: interne kandidaten gaan niet zelden voor. Loopbanen op interne arbeidsmarkten zijn over het algemeen opwaarts gericht. Dat geldt voor de functie-inhoud en dat geldt ook voor de beloning. Zolang de werknemer aan de verwachtingen kan voldoen, is het systeem in het voordeel van zowel de werknemer als de werkgever. De werknemer heeft een duidelijke prikkel tot prestatie en wordt daarvoor ook beloond. De boog moet gespannen blijven. Het nadeel van het systeem ontstaat op het moment dat de werknemer niet aan de verwachtingen voldoet en zijn prestaties niet verder toenemen of zelfs teruglopen. Er is dan vaak onvoldoende flexibiliteit in de arbeidsorganisatie om de arbeidsrelatie aan de gewijzigde omstandigheden aan te passen door horizontale mobiliteit of zelfs neerwaartse mobiliteit.

De arbeidskosten van de meeste werknemers stijgen met de leeftijd. Dat is vooral het geval voor hoger opgeleiden. Bij lager opgeleiden is er al snel in de loopbaan 
nog slechts sprake van een geringe stijging van de arbeidskosten (Ter Rele 2006). Anciënniteit speelt in de meeste cao's een rol in de beloningssystematiek. Dat kan betekenen dat oudere werknemers in relatie tot hun productiviteit meer betaald krijgen dan waar zij op een bepaald moment goed voor zijn.

De beloningsstructuur in veel arbeidsorganisaties zet een rem op de mobiliteit van werknemers. De beloningsstructuur is in belangrijke mate bepaald door aan functies gerelateerde loonschalen waarvan de invulling het product van onderhandeling tussen de sociale partners is. De productiviteit van de werknemer varieert met de leeftijd. Aan het begin van de loopbaan is de productiviteit door een gebrek aan ervaring laag. Vervolgens neemt de productiviteit toe om op een bepaald moment te pieken. Gelderblom c.s (2003) concluderen dat de productiviteit van werknemers gemiddeld iets boven de 50 jaar op het hoogste niveau ligt, terwijl dat 10 jaar eerder tussen 40 en 45 jaar was. Het is mogelijk dat een toegenomen aandacht voor scholing geleid heeft tot een stijging van de meest productieve leeftijd. Voortgaande investeringen in de arbeidsvaardigheden van oudere werknemers zouden deze leeftijd nog verder kunnen doen stijgen. De indruk bestaat dat de lagere productiviteit van oudere werknemers voor een deel het gevolg is van verwaarlozing in het onderhoud van hun inzetbaarheid.

In het voorgaande is duidelijk gemaakt dat het nagenoeg ontbreken van een arbeidsmarkt voor oudere werknemers aan de vraagzijde vooral te maken heeft met de arbeidskosten van oudere werknemers, met hun inzetbaarheid en met leeftijdsdiscriminatie. Maar oudere werknemers kunnen er zelf veel aan bijdragen om een werkende arbeidsmarkt voor oudere werknemers te creëren. Daarvoor zullen echter wel gunstige randvoorwaarden moeten worden geschapen. In hoofdstuk 7 wordt hierop teruggekomen.

\subsection{CONCLUSIES}

Flexibiliteit is noodzakelijk omdat het ervoor zorgt dat de juiste man/vrouw op de juiste plaats komt. De empirische gegevens weerspreken niet dat de Nederlandse arbeidsmarkt die functie vervult. Er is relatief veel creatie en destructie en baanwisseling. In een hoogconjunctuur profiteren alle inkomensgroepen van creatieve destructie. Uit het overzicht blijkt ook dat vrijwel alle arbeidsmarktgroepen in meer of mindere mate hun aandeel hebben in de mobiliteit en flexibiliteit. Er zijn geen scherpe contrasten waardoor de bewegelijkheid op de arbeidsmarkt exclusief aan één of meerdere groepen moet worden toegeschreven. Wel is er een aantal concentraties waarneembaar van groepen met een van het gemiddelde afwijkend patroon.

Zo doet externe mobiliteit zich vooral voor bij jonge mensen. Voor een deel is dat onderdeel van een normaal proces van toetreding tot de arbeidsmarkt. Schoolverlaters betreden de arbeidsmarkt vaak zonder precies te weten waar ze willen werken. In de eerste jaren van de loopbaan is het logisch dat er regelmatig van baan wordt gewisseld, terwijl men zoekt naar de best passende baan. Jonge 
mensen hebben ook nog geen hoge salarissen. Dat verklaart de combinatie van veel mobiliteit bij jongeren en lage aanvangssalarissen. Jongeren zijn de meest mobiele groep. Oorzaak hiervan is dat jongeren naast hun studie vaak een bijbaantje hebben op tijdelijke basis. Wanneer ze klaar zijn met studeren en de arbeidsmarkt betreden, breekt een fase aan waarin het zoeken naar de juiste baan centraal staat. Hierdoor wordt er vaak van werkgever gewisseld totdat de goede match gevonden is, men ondertussen al wat ouder is geworden en op zoek gaat naar meer stabiliteit. Ook geldt voor jongeren het meest dat tijdelijk werk gezien moet worden als opstapje voor vast werk. Voor deze categorie werknemers is er dan ook geen sprake van segmentatie. De hoge mobiliteit is als het ware natuurlijk, en wordt uiteindelijk 'beloond' met een vast contract. Wat lager opgeleide jongeren betreft, is er wel enige voorzichtigheid geboden. De klassiek werkende jongeren, op zoek naar een voltijdse vaste baan, wordt namelijk meer dan incidenteel weggeconcurreerd door de breder en flexibeler inzetbare student die een bijbaantje zoekt. Naast deze groep van jongeren voor wie mobiliteit op de arbeidsmarkt een vanzelfsprekend middel is om verbetering van positie te verwerven zijn drie groepen waarneembaar die worden geconfronteerd met lage kansen om toe te treden tot dan wel om werkzaam te blijven op de arbeidsmarkt.

1. Externe mobiliteit is problematisch voor oudere werknemers. In de zin dat het nauwelijks voorkomt bij oudere leeftijdsgroepen. Er is pas sprake van een arbeidsmarkt als er voldoende baanwisseling plaatsvindt. Zo bekeken kan men eigenlijk zeggen dat er (nog) geen arbeidsmarkt voor oudere werknemers bestaat.

2. Vrouwen bezetten in het begin van hun carrière voltijdbanen. Wanneer er gezinsuitbreiding komt, keren een aantal lager opgeleiden de arbeidsmarkt de rug toe. Hoogopgeleide vrouwen kiezen soms voor werken in deeltijdbanen. Ook na eventuele herintreding blijven veel vrouwen werken in grote deeltijdbanen. Ze doen dit wel langere tijd, en vaker in een vast dienstverband. In de verhouding tussen voltijd/deeltijd is de situatie van mannen versus vrouwen tegengesteld; in absolute zin werken viermaal zoveel vrouwen in deeltijd dan mannen, terwijl viermaal zoveel mannen als vrouwen voltijd werken.

Het werken in deeltijdbanen heeft er niet toe geleid dat vrouwen extra mobiel zijn. Voorzichtigheid is geboden voor de overgang van arbeidsmarkt naar zorg en andersom. Herintreding blijkt lastig, en ook de mogelijkheden om een binding met de arbeidsmarkt te houden moet, óók voor laagopgeleide vrouwen, gemakkelijk worden gemaakt.

3. Aan de onderkant van de arbeidsmarkt tekenen zich een aantal problemen af. Veelvuldige baanwisselingen, korte baanduur en werkloosheid zijn sterk geconcentreerd bij een beperkt aantal mensen. Ook in hoofdstuk 3 bleek al dat met name het opleidingsniveau de bepalende factor is: hoe lager het opleidingsniveau en daarmee de inkomenshoogte, hoe hoger de werkloosheid. De instroom van banen naar de werkloosheidsregelingen is substantieel. Jaarlijks stromen bijna 200.0oo personen naar de uitkeringsregelingen voor werkne- 
mers onder de 65 jaar. Dit is bijna 40 procent van het jaarlijkse totaal aan uittreders van de arbeidsmarkt. Het overgrote deel van deze groep zit in de leeftijdscategorie 30-55 jaar. Jaarlijks stromen circa 100.00o personen uit de uitkeringsregelingen terug naar de arbeidsmarkt. Slechts een kwart van de werklozen stroomt uit naar een baan in dienstverband of als zelfstandige. Nader onderzoek wijst erop dat we hier niet alleen te maken hebben met langdurige werkloosheid maar ook met herhalingswerkloosheid. Hoewel de werkloosheidsontwikkeling de afgelopen periode relatief gunstig is en de langdurige werkloosheid is gedaald, ziet de uitstroom uit de werkloosheid er zorgelijk uit.

4. Veel allochtonen hebben arbeidsmarktkwalificaties waardoor zij aangewezen zijn op het laagste segment. Maar behalve de kernmerken van laagopgeleiden in het algemeen kunnen allochtonen daarnaast nog andere tekorten vertonen die voor hen de toetreding tot de arbeidsmarkt extra kunnen bemoeilijken. Niet zozeer cognitieve vaardigheden staan centraal, maar vooral ook zaken als sociale vaardigheden, taalbeheersing, loyaliteit en motivatie spelen een rol bij het verkrijgen van een baan

5. Naast afstanden tot de arbeidsmarkt speelt vermoedelijk ook discriminatie een rol (WRR 2006: 205). Dit ondanks het feit dat een derde van de bedrijven een voorkeursbeleid heeft waarbij werving van allochtonen de meeste prioriteit geniet. Een serieuzer antidiscriminatiebeleid ligt daarmee in de rede (WRR 2006: 217). 


\section{NOOT}

I Ter oriëntatie, de bovengrens van het eerste deciel is in 2002 ongeveer 300 euro per maand. Bij een weekinkomen van 65 euro moet men denken aan bijverdiensten op basis van ca. 8 uur per week tegen het minimumloon. Personen in de eerste decielen zijn werknemers die geen volledig arbeidsinkomen hebben en op relatief kleine deeltijdbaantjes werken. Het minimumloon zit aan de bovengrens van het derde deciel. De bovengrens van het vijfde deciel is bijna 1900 euro per maand (het modale inkomen - de grens waarbij de ene helft van de werkende bevolking minder verdient en de andere helft meer dan dit maandinkomen, bedraagt ca. 1.6oo euro per maand). De benedengrens van het tiende deciel (het 'grootverdienersdeciel') is bijna 3.700 euro per maand. Dat is ruim twee keer het modale inkomen. 


\section{FLEXIBILITEIT EN SOCIAAL-ECONOMISCHE INSTITUTIES}

\subsection{INLEIDING}

Veel arbeidsmarktwetgeving staat thans bij veel economen in een kritisch daglicht. Arbeidsmarktregulering lijkt moeilijk verenigbaar met flexibilisering. Niettemin is het van belang flexibilisering van de arbeidsmarkt helder te onderscheiden van liberalisering van de regels die voor het functioneren ervan gelden. Het oogmerk van flexibilisering is het versoepelen van de arbeidsmarkt, zodat de allocatie van arbeid wordt geoptimaliseerd, aanpassingen snel kunnen verlopen, potentiële kwaliteiten worden ontwikkeld en benut, en de uitkeringsafhankelijkheid die vermijdbaar is wordt tegengegaan. Regels kunnen de flexibiliteit zowel bevorderen als hinderen. De vergelijking met het reguleren van verkeersstromen dringt zich op. Het verwijderen van verkeerslichten of rotondes op overvolle kruisingen zal niemand bepleiten, maar het weghalen van verkeerslichten die weggebruikers veroordelen tot wachten zonder dat er concurrerend verkeer is, verdient weer wel aanbeveling.

Dit hoofdstuk is een inventariserende zoektocht. Een vijftal belangrijke sociaaleconomische instituties wordt geïnventariseerd op hun invloed op de flexibiliteit van de arbeidsmarkt. In het bijzonder wordt onderzocht in hoeverre zij bijdragen aan een zodanige participatie dat de allocatie van arbeid en de arbeidsproductiviteit optimaal zijn, en welke mogelijkheden bestaan om hun effectiviteit op dat punt te vergroten. Als om die reden bepaalde varianten van een positieve beoordeling worden voorzien, dan komt die hier rechtstreeks voort uit deze doelstelling. De aanbevelingen van het rapport die in het volgende hoofdstuk worden gedaan, hebben een bredere basis.

Het ongunstige daglicht waarin arbeidsmarktregulering staat heeft ook te maken met de stand van de economische wetenschap. Op het niveau van de afzonderlijke instrumenten heeft veel sociaal beleid een negatief effect; relaties laten zich op gedesaggregeerd niveau ook betrekkelijk eenvoudig, want concreter beoordelen. Maar op het geaggregeerde niveau blijken de zogenaamde genereuze verzorgingsstaten het niet slechter, en niet zelden zelfs beter, te doen dan de liberaal ingerichte economieën. Hoofdstuk 4 van het recente WRR -rapport De verzorgingsstaat herwogen doet hiervan verslag (WRR 2006). Recente studies geven aan hoe moeilijk het is om op dit hogere niveau oorzakelijke verbanden aan te tonen, en tot welke grote verschillen van opvatting deze interpretatieruimte leidt (Agell 2002; Storm en Naastepad 2005; Pilat 2005). Veel arbeidsmarktregels hebben de voortdurende kritische aandacht van de sociale partners. Het is in Nederland niet goed voorstelbaar dat, als sociale partners gezamenlijk een andere regelgeving voorstaan waartegen het algemeen belang zich niet verzet, zo'n verandering lang zou uitblijven. Met dit oogmerk evalueert de Stichting van de Arbeid dan ook regelmatig wetgeving, waarvan de resultaten in het frequente tripartiet overleg 
met het kabinet worden besproken. Zo heeft de Stichting de Wet Flexibiliteit en Zekerheid geëvalueerd aan de hand van een onderzoek dat toont dat er een zeker evenwicht tussen flexibiliteit en zekerheid is ontstaan (Stichting van de Arbeid 2004). Ook de overheid zelf entameert regelmatig dereguleringsprojecten om de regelgeving van schadelijke elementen te ontdoen.

Flexibiliteit is een te algemeen begrip om zonder nadere duiding als leidsnoer te kunnen dienen voor het voeren van beleid. Zo acht Wilthagen c.s een hoger aandeel van werknemers met een vast contract een illustratie van het feit dat de flexibilisering van de arbeidsmarkt stagneert (Wilthagen et al. 2006: 154). De vraag is of dit wel terecht is; een vast contract biedt vaak een betere basis om het aanpassingsvermogen van werknemers te ontwikkelen dan een tijdelijk contract.

Arbeidsmarktregels kennen vaak vele aspecten, die elk voor bepaalde oogmerken schadelijk dan wel profijtelijk kunnen zijn. Gelet op de vele beleidswensen op het terrein van de arbeidsmarkt betreffende participatiegraden, aanpassingsvermogen, productiviteitsontwikkeling en verkorting van verblijfsduren in de sociale zekerheidsarrangementen, zullen daarom in dit hoofdstuk in de paragrafen 6.2 tot en met 6.6 achtereenvolgens de ontslagbescherming, het minimumloon, het arbeidsmarktbeleid, de Ww en de cao's worden bezien om te kijken op grond van welke voor- en nadelen wijziging van deze onderdelen mogelijk aanbeveling verdient. Ontslagbescherming, werkloosheidsregeling en activerend arbeidsmarktbeleid worden in de literatuur steeds meer in samenhang gezien; ze raken, in termen van dit rapport, primair respectievelijk de baanzekerheid, de inkomensbescherming en de werkzekerheid.

In het onderstaande schema staan de belangrijkste probleemgroepen gepresenteerd en wordt de relatie met de geselecteerde instituties geduid. De eerste twee groepen, ouderen en laagopgeleiden, hebben een deelnemingsgraad lager dan de helft van het gemiddelde. De participatie van de derde groep, de uitkeringsontvan-

\section{Schema 6.1 Relatie doelgroepen en geselecteerde instituties}

\begin{tabular}{|c|c|c|c|c|c|}
\hline & $\begin{array}{r}\text { Ontslag- } \\
\text { recht }\end{array}$ & $\begin{array}{r}\text { Minimum- } \\
\text { loon }\end{array}$ & $\begin{array}{l}\text { Arbeids- } \\
\text { marktbeleid }\end{array}$ & WW & $\begin{array}{l}\text { Cao- } \\
\text { bepalingen }\end{array}$ \\
\hline \multicolumn{6}{|l|}{ Lage participatie } \\
\hline Ouderen & $\checkmark$ & & & & \\
\hline Laagopgeleiden & & $\checkmark$ & & & $\checkmark$ \\
\hline Uitkeringsontvangers & & & $\checkmark$ & $\checkmark$ & \\
\hline Transities & & & & & \\
\hline Jeugdigen & & & $\checkmark$ & & $\checkmark$ \\
\hline Vrouwen & & & $\checkmark$ & & $\checkmark$ \\
\hline Werkenden & $\checkmark$ & & & $\checkmark$ & $\checkmark$ \\
\hline
\end{tabular}


gers, kan bij arbeidsongeschiktheid en bij een herhaaldelijk gebruik veel lager uitvallen dan bij een op activering gericht beleid nodig is. De volgende drie groepen zijn vermeld met het oog op de overgangsproblematiek: bij jongeren gaat het om de aansluiting van werk op school, bij vrouwen om de overstap van zorgtaken naar betaalde arbeid en bij werkenden om een soepele baanwisseling wanneer de noodzaak (ontslag) of wenselijkheid (betere allocatiemogelijkheden) hierom vraagt.

\subsection{ONTSLAGBESCHERMING}

\subsubsection{INLEIDING EN BESCHRIJVING VAN DE PRAKTIJK}

De meeste beëindigingen van arbeidsrelaties in ons land vinden plaats met instemming van beide partijen. Het gaat dan onder meer om het vertrek van werknemers na afloop van een tijdelijk contract, beëindiging met wederzijds goedvinden of ontslag gedurende een proeftijd. Het aantal onvrijwillige beëindigingen vormt slechts circa 20 procent van het totaal (Van Zevenbergen en Oelen 2000: IV).

De wetgever heeft in ons land geregeld dat een arbeidsovereenkomst niet eenzijdig mag worden beëindigd, tenzij hiervoor toestemming is verleend. Deze toestemming kan worden afgegeven door het CWI dan wel door de rechter. Uitgangspunt voor de toekenning is de vraag of het ontslag op goede gronden wordt aangevraagd. De ontslagbescherming in Nederland neemt een middenpositie in ten opzichte van andere OECD-landen (OECD 2004: 72). Deze positie wordt in belangrijke mate bepaald door de bescherming voor tijdelijke arbeid die aan relatief weinig eisen hoeft te voldoen. Voor reguliere banen echter is de ontslagbescherming hoger dan in de meeste andere OECD-landen (CPB 2006b: 134 en 135).

Het unieke duale stelsel in ons land, waarbij zowel het CWI als de rechter de toestemming voor het ontbinden van de arbeidsovereenkomst kan verlenen, is al vaak onderwerp van discussie geweest (Commissie-Rood 200o). Het duale stelsel bevat enkele incongruenties. Het CW I beoordeelt primair de rechtmatigheid van het ontslag, de rechter vooral de billijkheid ervan. Het CWI stelt als regel geen ontslagvergoeding vast, de rechter wel. Bovendien sluiten de regelingen elkaar niet uit: de werknemer kan ook, nadat de ontbinding van de arbeidsrelatie door het CWI is toegestaan, een beroep doen op de rechter. Het CWI beoordeelt de rechtmatigheid van het ontslagvoorstel op twee gronden: de bedrijfseconomische situatie en in de persoon van de werknemer gelegen overwegingen. De werkgever moet daarom zijn verzoek tot ontslag doen vergezellen van een schriftelijke onderbouwing. Hoewel de procedure via het CWI op zichzelf kosteloos is, zijn er aan een ontslag wel kosten verbonden. Het gaat om de volgende posten:

- opstellen van de benodigde documenten ter onderbouwing van de aanvraag;

- loondoorbetaling gedurende de periode dat de procedure loopt (variërend van 44 tot 67 dagen, zie Knegt 20oo: 67-68); 
- loondoorbetaling gedurende de opzegtermijn na de uitspraak van het CWI;

- eventuele (vrijwillige) ontslagvergoeding.

Ondanks deze kosten wordt de keuze voor de CWI-route primair ingegeven door het feit dat de route via de kantonrechter nog duurder is (Van Zevenbergen en Oelen 2000: vi). Het gaat dan om de kosten van juridische bijstand, maar vooral ook om de hoge ontslagvergoedingen. Bijna alle werkgevers laten zich bij een procedure juridisch bijstaan (Bureau Bartels 2006: 32), met alle financiële consequenties van dien. Daarnaast zijn er de ontslagvergoedingen conform de zogenaamde kantonrechtersformule, inhoudende dat elk dienstjaar tot de toekenning van een maandsalaris leidt met inachtneming van een vermenigvuldigingsfactor wanneer leeftijd of overwegingen van billijkheid daartoe aanleiding geven.

De kosten van de CWI-procedure liggen belangrijk lager dan die van de route via de kantonrechter. Volgens een onderzoek gehouden onder werkgevers liggen de kosten van een ontslag in het laatste geval ongeveer vijfmaal hoger dan in het eerste geval (Van Zevenbergen en Oelen 200o: 28). De hoogte van de eenmalige ontslagvergoedingen varieert, zoals de kantonrechtersformule doet vermoeden, sterk. Een derde ontvangt een bedrag lager dan 10.000 euro, een derde een bedrag tussen 10.000 en 50.000 euro, en een derde een bedrag dat vanaf 50.000 euro kan oplopen tot 640.00o euro (Knegt 2005: tabel 8). Het zijn juist deze ontslagvergoedingen die Nederland onderscheiden van andere landen (Deelen et al. 2006).

Ofschoon het CWI geen ontslagvergoedingen toekent, kunnen deze natuurlijk wel door de werkgever worden verleend. In ongeveer de helft van de gevallen gebeurt dat ook (Knegt 2005: tabel 2). Ook buiten de sfeer van gedwongen ontslagen worden vergoedingen toegekend. Ongeveer twee derde van de sociale plannen die bij een reorganisatie of inkrimpingsoperatie worden opgesteld, kennen een vertrekstimuleringsregeling. De bedragen die bij vrijwillig ontslag worden toegekend zijn in niet geringe mate geïnspireerd door de kantonrechtersformule en kunnen de hoogte ervan zelfs te boven gaan (Tros et al. 2005: 530-531). Kijken we naar de redenen voor de ontslagaanvragen, dan is er informatie beschikbaar voor zover het gaat om de CWI-route.

De bovengenoemde ontslagredenen zijn in hoge mate bepalend voor de keuze van de route: via CWI dan wel kantonrechter. Bij bedrijfseconomische omstan-

Tabel 6.1

Ingediende ontslagaanvragen 2005 naar reden

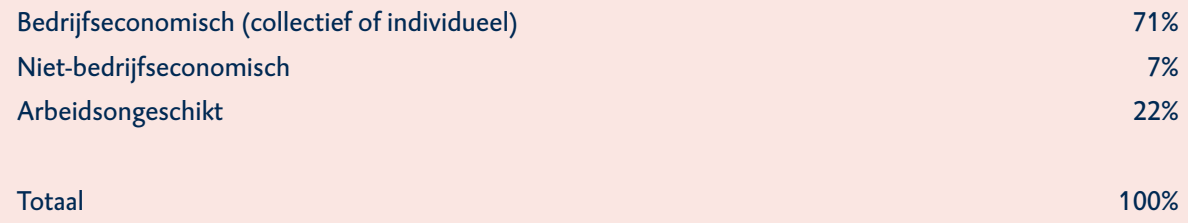


digheden en arbeidsongeschiktheid wordt voor het overgrote deel gekozen voor het CWI; bij ontslag vanwege in de persoon gelegen factoren (disfunctioneren; verwijtbaar handelen zoals diefstal; verstoring arbeidsrelatie) is de kantonrechter evident favoriet (Van Zevenbergen \& Oelen 2000: 23; Van Ewijk en Engelen 2001: 2O; Bureau Bartels 2006: 49). Het aantal zaken bij het CWI en de kantonrechter is vrijwel gelijk; naar grootte van de bedrijven gezien maakt vooral het MKB gebruik van de CWI-route.

Ten slotte nog een opmerking over het preventieve karakter. Het oogmerk van de preventieve ontslagtoets is immers het voorkomen van onredelijke ontslagen. In niet weinig gevallen worden verzoeken om ontslagen door het CWI niet gehonoreerd. Toch blijken in de praktijk nagenoeg alle werknemers voor wie de werkgever een ontslagaanvraag heeft ingediend, uiteindelijk toch te zijn vertrokken (Van Zevenbergen en Oelen 20oo: 46). Het oogmerk van het in stand houden van de arbeidsrelatie wordt derhalve niet verkregen. Deze conclusie verdient echter nuancering. Omdat de inspanningen en kosten verbonden met (het indienen van) een ontslagaanvrage hoog zijn, kan de preventieve werking zich ook uitstrekken tot het uitblijven van dergelijke aanvragen. In díe gevallen is het minder waarschijnlijk dat de werknemers de arbeidsrelatie beëindigen, omdat de wens van de werkgever dan niet tot uitdrukking komt in een ontslagaanvrage.

\subsubsection{SOCIAAL-ECONOMISCHE ASPECTEN}

Ontslagbescherming is primair ingegeven door de wens om de werknemer te beschermen tegen ongemotiveerde beslissingen van de werkgever om de arbeidsovereenkomst te beëindigen. Daarmee wordt tevens voorzien in een vorm van inkomenszekerheid. Omdat ontslagbescherming bijdraagt aan de stabiliteit van de arbeidsrelatie, wordt het voorts aantrekkelijker voor de werknemer om te investeren in de kwaliteit van die relatie. Ook beperkt de ontslagbescherming de instroom in de werkloosheidsregeling. Tegenover deze voordelen staan ook nadelen. Bedrijfseconomisch wenselijke beëindigingen van arbeidsovereenkomsten kunnen door ontslagbescherming worden verhinderd. Daardoor kunnen er minder baanopeningen ontstaan voor nieuwe toetreders. In zoverre discrimineert ontslagbescherming de outsiders - doordat de werkloosheidskansen onevenwichtig worden verdeeld - in nadelige zin ten gunste van de insiders. Voorts verhogen de kosten van een ontslagvergunning de loonkosten. Berekend is dat een vermindering van de ontslagbescherming met 40 procent de werkloosheid met 0,4 procentpunt zou doen verminderen (СРB 2006b: 137). Ook Belot en Van Ours concluderen dat ontslagbescherming een negatief effect heeft op de arbeidsmarktdynamiek, met name op baancreatie en op de transities tussen werkloosheid en werkgelegenheid (Belot en Van Ours 2007). Maar er zijn ook studies die concluderen dat het wegnemen of verlichten van de ontslagbescherming economisch nadelig is (Storm en Naastepad 2005).

In het streven naar werkzekerheid zou het gewenst zijn om de ontslagbescherming om te bouwen naar een mobiliteitsbevordering. Tegenover het risico van 
baanverlies staat dan de waarborg dat de overgang naar een volgende baan zal worden bewerkstelligd. Om dit begrip van werkzekerheid nader vorm te geven zijn diverse gedachten ontwikkeld, die variëren op de omzetting van de ontslagvergoeding naar een vergoeding voor scholing, voor een reïntegratietraject, of voor een termijn gedurende welke men een andere baan probeert te vinden (Verhulp 2005a: 22). Uitwerking van deze gedachten, het investeren in mobiliteit via employability, roept enkele vragen op. Wie is verantwoordelijk voor het investeren in employability? Is een dergelijke investering een afdoende alternatief of kan dit worden gecombineerd met vormen van zekerheden dat men ook een nieuwe baan zal vinden? Moet de employability-investering op iedereen van toepassing zijn of alleen op degenen die met ontslag worden bedreigd, of alleen op degenen met een zodanige arbeidsmarktpositie dat hun kansen op een nieuwe baan beperkt moeten worden geacht? Het afhankelijk maken van ontslagbescherming van employability impliceert een zekere verplaatsing van de verantwoordelijkheid van de werkgever naar de werknemer. Wijzigingen in een loopbaan vergen immers primair het engagement van de betrokkene zelf.

Een aantal van de hierboven genoemde voordelen kan ook op andere wijze worden verkregen dan door middel van ontslagbescherming. Inkomensbescherming wordt ook geboden door de ww, terwijl de afwenteling op de ww kan worden tegengegaan door een ontslagbelasting of door premiedifferentiatie. Tevens kan men denken aan een verplichting aan het UWV om gedurende de eerste fase van de werkloosheidsperiode de wW uitsluitend uit te keren als tegenprestatie voor deelname aan een reïntegratietraject. Het ontbreken van enigerlei vorm van ontslagbescherming zou echter ook stabiliteit aan de arbeidsrelatie kunnen ontnemen, waardoor deze niet alleen korter kan worden maar ook kwalitatief wijzigingen zou kunnen ondergaan.

\subsubsection{ARBEIDSRELATIES EN ONTSLAGBESCHERMING}

Stabiele arbeidsrelaties bieden evidente voordelen. Kortdurende arbeidsrelaties verhogen de arbeidskosten, omdat de minder productieve inwerkfase een groter deel gaat uitmaken van de totale baanduur. Stabiele relaties leiden ook tot een commitment van de kant van de werknemer waardoor de productieve prestatie zal toenemen en risico's van bedrijfsdiefstal of dagdieverij afnemen. Stabiele arbeidsrelaties zullen ook het klimaat doen ontstaan waarin investeringen in human capital zullen plaatsvinden. Veelal wordt hierbij gedacht aan bedrijfsscholing waarmee het technische kennisniveau wordt vergroot of verbreed (Belot en Van Ours 2007: 10). Storm en Naastepad (2005) concluderen dat "werknemers meer gemotiveerd zijn om hun kennis en vaardigheden aan te wenden ten bate van de onderneming, als ze in voldoende mate door het arbeidsbestel worden beschermd”.

Niet zonder belang zijn naast deze technische vaardigheden de sociale en communicatieve vaardigheden. Een aantal ontwikkelingen maakt juist deze laatste vaardigheden actueel. Ten eerste is er de voortdurende structuurverschuiving naar de postindustriële samenleving. Veruit de meeste werkgelegenheid bevindt 
zich thans in de dienstensectoren waarin klant- en servicegerichtheid een veel toonaangevender rol spelen dan in de industrie of landbouw. Ten tweede heeft zich in de afgelopen decennia een proces voltrokken waarbij individuele werknemers meer en meer op hun persoonlijke bijdrage aan het bedrijfsresultaat worden beoordeeld. In het verlengde hiervan worden werknemers meer bewust gemaakt van de wijze waarop hun werkzaamheden van invloed zijn op het eindproduct. Oriëntatie op afnemers en klantgerichtheid krijgt ook langs deze weg een accent. De sociale dimensie en het ontwikkelen van maatschappelijke competenties krijgen daardoor naast de traditionele scholingscursussen een steeds belangrijker aanzien (SER 2002a: 42).

Veel van deze vaardigheden kunnen het beste in de relevante context, te weten op de werkplek, worden verworven. Het lijkt gewenst dat arbeidsrelaties zodanig bestendig zijn dat deze leeraspecten adequate aandacht kunnen krijgen, ook voor degenen die in dit opzicht relatief grote achterstanden vertonen. In dit licht bezien lijkt de vormgeving van de preventieve ontslagtoets van belang. Bij ontslagaanvragen op grond van het disfunctioneren van werknemers dient uit stukken te blijken dat de werkgever de werknemer heeft gewezen op zijn tekortkomingen en op de mogelijkheden om deze weg te nemen of althans te verminderen. Daartoe worden werkverslagen, beoordelingen en verslagen van functioneringsgesprekken overgelegd (Knegt 20oo: 64). Op deze wijze wordt de zogenaamde poortwachtersfunctie, die erop gericht is dat geen werknemers worden toegelaten tot de ww die door adequaat optreden van de kant van de werkgever werkzaam hadden kunnen blijven, door het CWI goed ingevuld. De vraag blijft of met deze zeef niet te veel ontslagen worden tegengehouden.

Idealiter moet de ontslagbescherming ertoe bijdragen dat de optimale baanduur wordt bereikt. De hoogte van deze optimale duur is van vele factoren afhankelijk en kan per werknemer variëren. Zo merkt het СРB terecht op dat "ontslagbescherming de prikkels van werknemers om te investeren in blijvende inzetbaarheid vermindert" (СРВ 1999: 123). Dit kan natuurlijk ook de inzetbaarheid van de werknemer bij de eigen werkgever betreffen. Baanonzekerheid wordt dan als positieve factor gezien. Iets vergelijkbaars geldt voor het investeren in human capital. Ook bij afwezigheid van elke vorm van ontslagbescherming zal een werkgever investeren in de technische en sociale vaardigheden van medewerkers om hun productieve bijdrage aan het bedrijfsresultaat te verhogen. Werkgevers menen dan ook in grote meerderheid dat een aanzienlijke versoepeling van het ontslagrecht niet van invloed is op hun scholingsbeleid (Bureau Bartels 2006: 88). De waardering van de verschillende factoren is dus nauw verbonden met de vormgeving van de ontslagbescherming.

\subsubsection{KNELPUNTEN}

Naast macro-economische aspecten en overwegingen kan ook worden gekeken naar de concrete knelpunten van het ontslagstelsel zoals die thans worden ervaren. 
Een eerste onderwerp betreft het voor ons land unieke duale ontslagstelsel. In het verleden is het duale karakter van het ontslagstelsel vaak onderwerp van discussie geweest. Diverse malen is reeds voorgesteld om de preventieve ontslagtoets te vervangen door een repressieve (Commissie-Rood 2000: 143). Niet uitgesloten is dat het hierbij gaat om niet zozeer een praktisch als wel een theoretisch knelpunt, omdat "de rechtspraktijk inmiddels heel goed met die twee wegen [blijkt] te kunnen leven” (Staal 2005: 456).

Om inzicht te krijgen in de knelpunten die in de dagelijkse praktijk worden ervaren kan aansluiting worden gezocht bij onderzoeken die hiernaar zijn gedaan. Onderzoek uit 2000 laat zien dat bijna 40 procent van de werkgevers van oordeel is dat het duale stelsel te weinig bescherming biedt aan de belangen van de werkgever (tegenover 33 procent die vindt dat deze bescherming wel voldoende is). Gaat het om de bescherming van de werknemer, dan vinden werkgevers in grote meerderheid dat deze voldoende wordt beschermd (Van Zevenbergen en Oelen 2000: 58-59). Recent onderzoek toont dat werkgevers in grote meerderheid (bijna 80 procent) vinden dat het ontslagrecht de bedrijfsvoering hindert. Het blijkt dat met name de moeilijkheden die men ondervindt om slecht functionerende medewerkers te ontslaan, voor deze opvatting de meest genoemde verklaring vormt. Een andere klacht is dat, wanneer het dan toch tot ontslag komt, er een ontslagvergoeding verstrekt moet worden. De hoogte ervan wordt door de meeste werkgevers irreëel genoemd (Bureau Bartels 2006: 62, 63, 71 en 46).

In het licht van de hierboven genoemde categorie van slecht functionerende werknemers is het interessant de gevolgde ontslagroutes nog eens nader te bezien. Ten opzichte van de totale groep werknemers, dus inclusief degenen die om bedrijfseconomische redenen worden ontslagen, of om redenen van arbeidsongeschiktheid, gaat het immers om een categorie van minder dan 1o procent van de goedkeuringen die door het CWI aan ontslagaanvragen worden toegekend (szW 2005: 4). Het is aannemelijk dat, zoals besproken, dit percentage hoger ligt voor de ontbindingen die via de kantonrechter tot stand komen. Omdat de beëindigingen van arbeidsverbanden via het CWI dan wel de kantonrechter tezamen ongeveer 20 procent van het totaal van de beëindigingen beloopt, en het deel dat om persoonlijke redenen wordt ontslagen relatief klein is, vormt deze laatste groep slechts een gering percentage van het totaal der beëindigingen. Uitgaande van de cijfers die beschikbaar zijn voor de instroom in de ww blijkt dat ontslagen als gevolg van in de persoon gelegen omstandigheden ongeveer 4 procent van het totale aantal beëindigingen betreffen (Van Ewijk en Engelen 2001: 40, tabel A 10). Toch is het juist deze groep die ondanks het lage gewicht de steen des aanstoots lijkt te zijn. Een verklaring hiervoor kan worden gevonden door te kijken naar de ontslagroutes. Ofschoon het totale aantal procedures via enerzijds het CWI en anderzijds de kantonrechter al enkele jaren ongeveer dezelfde aantallen vertoont, loopt de samenstelling fors uiteen.

Aanvragen vanwege bedrijfseconomische redenen en vanwege arbeidsongeschiktheid gaan in meerderheid naar het CWI; verzoeken om ontbinding van 
arbeidsrelaties vanwege persoonlijke omstandigheden (slecht functioneren, ongeschiktheid voor functie) gaan in hoofdzaak naar de kantonrechter (Van Zevenbergen en Oelen 2000: 23; Van Ewijk en Engelen 2001: 40). De verklaring voor dit grote verschil ligt aan het feit dat de CWI-route in het geval van een ontslagaanvrage om persoonlijke redenen veel voorbereidingen vergt, tijdrovend is en bovendien weinig zekerheid biedt of de aanvrage ook wordt toegekend (Van Zevenbergen en Oelen 2000: VI; Van Ewijk en Engelen 2001: 33; Bureau Bartels 2006: 42, 49 en 50). De route via kantonrechter heeft deze nadelen niet, omdat deze er als regel van uitgaat dat het verzoek om tot ontbinding van een arbeidsrelatie over te gaan impliceert dat een voortzetting ervan geen perspectief biedt. De kantonrechter concentreert zich daarom in de meeste gevallen op de hoogte van de toe te kennen ontslagvergoeding. Dat maakt deze route weliswaar helder en duidelijk, maar ook tot een kostbare aangelegenheid. Voor relatief kleine bedrijven kan zo'n financiële last te hoog zijn om te dragen, zodat blijkt dat vooral bedrijven met meer dan 100 werknemers gebruikmaken van de kantonrechtersroute (Bureau Bartels 2006: 48; Van Zevenbergen en Oelen 2000: 34).

Voor het midden- en kleinbedrijf is er dan eigenlijk geen alternatief, omdat de route via het CWI tijdrovend, veeleisend en onzeker is. Deze drie aspecten staan niet los van elkaar. In het geval van slecht functioneren of verwijtbaar handelen dient de werkgever een dossier te overleggen waaruit dit blijkt. Ook wordt van de werkgever verlangd pogingen te hebben ondernomen om het functioneren te doen verbeteren. Beide eisen zijn moeilijk verenigbaar: men moet investeren in verbeteringen en tegelijk rapportages aanleggen met een negatieve strekking die anticiperen op ontslag (Knegt 2000: 64). Voorts valt disfunctioneren heel moeilijk met objectieve precisie te meten. Veel kwalificaties lenen zich voor interpretatie en hebben daardoor het risico te leiden tot een welles-nietesdiscussie (Knegt 2000: 64). Voordat een dossier zodanig helder is dat er een ontslagaanvrage op kan worden gebaseerd, moet er veel evident en aantoonbaar materiaal zijn overlegd. Deze eisen leiden ertoe dat, na een eerste contact met het CWI, lang niet alle wensen om tot ontslag over te gaan tot een aanvrage leiden. Ook in het vervolgtraject valt een aanzienlijk deel af: van de wel ingediende aanvragen wordt 11 à 13 procent niet in behandeling genomen en van de aanvragen die wel worden bezien, wordt 33 procent weer ingetrokken nadat om aanvullende informatie is gevraagd. Van de resterende aanvragen wordt uiteindelijk 94 procent gehonoreerd. Per saldo blijkt dat in het geval van ontslag om persoonlijke redenen 56 procent van de ingediende aanvragen wordt gehonoreerd, en als rekening wordt gehouden met het ontmoedigende effect van de eerste contacten met het CWI, dan gaat het om minder dan de helft (Knegt 2000: 64-67). Voor 2005 is het percentage van 56 overigens opgelopen naar 67 (szW 2005: 6), maar onbekend is nog steeds het ontmoedigingseffect.

Deze percentages kunnen natuurlijk geen uitsluitsel geven over de kwaliteit van de ontslagbescherming. De wetgeving moet werknemers beschermen tegen willekeur, zodat onrechtmatige vormen van ontslag worden voorkomen. Het probleem is natuurlijk dat in concrete gevallen het verre van eenvoudig is om 
slecht functioneren aantoonbaar te maken. Wat de verschillende stappen wel laten zien is dat er werkgevers kennelijk veel aan gelegen is om de ontslagaanvrage gehonoreerd te zien. Wanneer het gaat om de wensen van werkgevers ten aanzien van een aanpassing van het ontslagstelsel, dan blijkt dat de opvatting dat "functioneren (en competenties) een belangrijker criterium zou moeten zijn voor ontslag" het meest wordt geuit, namelijk door 59 procent van alle geraadpleegde werkgevers (Bureau Bartels 2006: 100). Ook het feit dat van alle groepen die in de WW instromen, degenen met een CWI-procedure er het langste verblijven, is geen indicatie dat het gaat om werknemers die relatief snel een (andere) werkgever weten te vinden (Van Ewijk en Engelen 2001: 22).

Om de nadelen van de CWI-route te omzeilen kiezen de meeste werkgevers voor de route via de kantonrechter. De kosten hiervan nemen zij op de koop toe. Voor de werkgevers die zich zo'n uitgave niet kunnen veroorloven, ontbreekt echter dit alternatief. Vooralsnog heeft dit bij sociale partners niet geleid tot een voorkeur voor een ander ontslagstelsel (SER 2005: 16).

Behalve dit belangrijke knelpunt zijn er nog andere mineure kwesties. Zo wordt de duur van de ontslagprocedures bij arbeidsongeschiktheid fors verlengd wanneer om een advies wordt gevraagd aan de uitvoeringsinstantie. Door gebruik te maken van het dossier dat op basis van de Wet Verbetering Poortwachter al beschikbaar is, kan de procedure belangrijk worden verkort. Ook enkele verbeteringen met betrekking tot collectief ontslag lijken binnen de bestaande wetgeving mogelijk (Bureau Bartels 2006: 56-57).

\subsubsection{SLOTOPMERKINGEN}

Het huidige duale stelsel gebaseerd op een preventieve ontslagtoets, lijkt, hoe uitzonderlijk dit stelsel ook is ten opzichte van andere Europese stelsels, als regel geen noemenswaardige problemen op te leveren. Dit geldt dan met name voor de ontslagen om bedrijfseconomische redenen en vanwege arbeidsongeschiktheid door ziekte. Voor de relatief kleine categorie van ontslagen vanwege in de persoon gelegen omstandigheden, lijken er wel problemen te zijn. Ook al blijkt deze categorie slechts enkele procenten te belopen van het totaal der beëindigingen, het vormt wel de bron van vele klachten die werkgevers hebben ten aanzien van het ontslagstelsel. Deze klachten zijn tweeledig: enerzijds gaat het om de lage kansen om via de CWI-route tot goedkeuring van een ontslag te komen, anderzijds gaat het om de ontslagvergoedingen die de rechter toekent en die tot hoge bedragen kunnen oplopen.

Het probleem van de CWI-route is de moeilijke bewijsvoering op grond waarvan ontslag op redelijke grond kan worden verleend. Deze bewijsvoering leidt tot een groot tijdsbeslag, veeleisendheid en onzekerheid over de uitkomst. Disfunctioneren is moeilijk zodanig te registreren dat er geen ruimte is voor weerleggingen. Dossiers kan worden tegengeworpen dat een andere interpretatie van gebeurtenissen, verantwoordelijkheden en taakopvattingen tot andere conclusies leidt. Het aanvechten van de redelijkheid van het ontslag met het oogmerk 
om de ontbinding van de arbeidsrelatie te voorkomen, speelt bij de kantonrechtersroute in veel mindere mate. De kantonrechter beoordeelt de billijkheid immers overwegend ter vaststelling van de ontslagvergoeding. Omdat voor de groep van minder functionerende werknemers de kantonrechtersroute het meest frequent wordt gevolgd, heeft de preventieve werking aldus sterk aan betekenis ingeboet.

\subsection{HET MINIMUMLOON}

\subsubsection{INLEIDING}

Het minimumloon kreeg algemene ingang in de Nederlandse arbeidsverhoudingen op grond van het Buitengewoon Besluit Arbeidsverhouding 1945. Dit besluit vormde de basis voor het College van Rijksbemiddelaars om cao's goed te keuren, waarbij ook criteria werden gehanteerd met betrekking tot de laagste lonen. De minimaal toegestane hoogte hiervan werd afgeleid van het bedrag nodig om in bescheiden kosten van levensonderhoud te voorzien. In 1969 werd de Wet Minimumloon van kracht, met een generieke werking. Daarmee kwam een eind aan de periode waarin het minimumloon primair van toepassing werd geacht op vakvolwassen mannelijke werknemers en voor vrouwen kon worden afgeweken van het minimumloon. Met ingang van 1972 werd de aanpassing van het minimumloon afhankelijk gesteld van de ontwikkeling van de regelingsloonindex (Teulings et al. 1998: 33-50).

Het aandeel WML'ers in de werkgelegenheid bedraagt momenteel iets meer dan 5 procent, met een oververtegenwoordiging van vrouwen en jongeren. Het brutominimumloon bedraagt nu iets meer dan de helft van het modale loon. In nettotermen gaat het om iets minder (alleenstaanden) of iets meer dan 70 procent (gehuwden). Een gehuwde minimumloner draagt in ons land de facto nauwelijks bij aan de collectieve middelen. De ratio van het brutominimumloon en het gemiddelde loon (dat iets hoger ligt dan het zgn. modale loon) van 50 procent is het resultaat van het in de jaren tachtig gevoerde beleid van ontkoppeling. In 1983 bedroeg deze ratio nog 62 procent. Hierdoor is in het gebied tussen dit achtergebleven minimumloon en de hoogte die het gehad zou hebben als het in dezelfde mate zou zijn gestegen als de overige lonen, een extra werkgelegenheid ontstaan van 600.00o banen (Vogels 2003: Di1). Dit grote effect laat zien dat het brutominimumloon vergeleken met 1983 naar een veel evenwichtiger niveau is gedaald; een verdere daling zal dan ook zeker niet meer zo'n werkgelegenheidseffect teweegbrengen.

Het minimumloon wordt sinds 1991, net als de uitkeringen, jaarlijks bezien op basis van de WKA, de Wet Koppeling met Afwijkingsmogelijkheid. De aanpassing volgt de regelingsloonindex (koppeling aan de loonstijging), maar hiervan kan worden afgeweken wanneer de ontwikkeling van de verhouding actieveninactieven daartoe aanleiding geeft. 
De totstandkoming van de hoogte van het minimumloon vormde in 1990 aanleiding voor de WRR om te adviseren om het minimumloon niet langer te baseren op de minimumbehoeften van een gezin maar op de individuele behoeften. Uitgaan van een minimumloner als gezinshoofd was immers nog slechts van toepassing op ongeveer o,4 procent van de werknemers (WRR 1990: 11). Verlaging van het minimumloon tot 70 procent van het toen geldende niveau, lag dus in de rede. In de reactie op het rapport stelde de regering dat kostwinners op minimumniveau ruim vertegenwoordigd zijn onder uitkeringsontvangers. Door het voor hen relevante loon op de arbeidsmarkt met 30 procent te verlagen ten opzichte van de uitkering zou hun het perspectief op een financieel profijtelijke terugkeer naar de arbeidsmarkt worden ontnomen.

De hoogte van het minimumloon wordt als cruciaal gezien voor de werkgelegenheid in het arbeidsmarktsegment dat zich op en vlak boven dit loonniveau bevindt. Voor de werkgelegenheidssituatie van laagopgeleiden is het minimumloon zeker van belang, al is het bepaald niet het enige instrument. Voor wat betreft de hoogte van het minimumloon lijkt de wet van vraag en aanbod te dicteren dat een lager minimumloon altijd beter is voor de werkgelegenheid dan een hoger niveau. Maar wat voor producten opgaat, geldt niet ook voor arbeidskrachten. Als een kritische grens wordt overschreden, gaan negatieve effecten domineren (Teulings et al. 1998: 104). Daarom is recentelijk het minimumloon in het VK ingevoerd, en daarom ook werden voor de vs positieve verbanden gevonden tussen de hoogte van het minimumloon en de werkgelegenheid op dit loonniveau. In hun studie concludeert Teulings c.s. dan ook dat "de invloed van het minimumloon wordt overschat" (Teulings et al. 1998: 134). Dat in de OECDlanden allerlei combinaties van hoogte van het minimumloon enerzijds en de hoogte van de werkloosheid onder laagopgeleiden anderzijds voorkomen, geeft aan dat andere factoren in het spel zijn (SZW 2000: 37).

De participatie onder laagbetaalden is zoals bekend relatief laag. In het OECDgebied is de werkgelegenheid onder laagbetaalden circa 50 procent tegenover 80 procent voor de hoger opgeleiden groepen (OECD 2003: 86-87). Deze constatering doet vermoeden dat het opleidingsniveau dé allesbeheersende factor is. Gelet evenwel op de verschillen in participatiegraden onder laagbetaalden tussen de OECD-landen, die variëren van 20 tot 80 procent, zijn de kansen op een baan ook voor de laagopgeleiden afhankelijk van het gevoerde beleid. Nederland behoort tot de landen die relatief gunstig scoren met de werkgelegenheid onder laagopgeleiden, en beter dan landen met een laag minimumloon zoals Amerika en Engeland. Dit illustreert de hierboven geformuleerde opvatting dat het minimumloon niet dominant is ter verklaring van de arbeidsmarktparticipatie van de laagopgeleiden. Uitgaande van de in ons land gebruikte definities blijkt dat van de laagopgeleiden 51 procent participeert en van degenen met alleen basisonderwijs minder dan 40 procent (sZW 2004: 3), tegenover 85 procent voor hoogopgeleiden (RWI 2005: 52). Hoe lager de opleiding, hoe lager de arbeidsdeelname. 
De relatief geringe participatie wordt niet weerspiegeld in de werkloosheid. Het werkloosheidspercentage voor mensen met uitsluitend basisonderwijs bedraagt 8 procent (SzW 2004: 3). Dit komt omdat er naast de groepen werkenden en werkzoekenden ook nog een groep inactieven is die niet op zoek is naar een baan. Van deze groep is een groot deel uitkeringsontvangers. Terwijl personen met uitsluitend basisonderwijs, mavo of vmbo ongeveer een derde deel van de bevolking van 25-64 jaar uitmaken (RWI 2005: 44, fig. 30), is het aandeel van deze opleidingscategorieën in de uitkeringen 55 procent. Met andere woorden: de relatieve kans om een uitkeringsontvanger is 2 à 2,5 maal zo groot bij personen uit de laagste opleidingsniveaus als bij de hoger opgeleiden. Het lijkt dus ook zaak om mensen met een uitkering de overstap te doen maken naar de arbeidsmarkt. De vraag die dan opkomt, is of er voor hen wel voldoende banen zijn. En ook of zij wel gemotiveerd zijn, omdat immers in ons land het minimumloon grosso modo eenzelfde netto-inkomen oplevert als het sociale minimum. De vraag is ook of werkgevers laagopgeleide personen willen aannemen als ze ook hoger opgeleide werknemers kunnen krijgen.

\subsubsection{VRAAG- EN AANBODVERHOUDINGEN}

Door de Raad voor Werk en Inkomen (RWI) is berekend dat om de participatiegraad onder laagopgeleiden dezelfde te doen zijn als die van hoogopgeleiden, er 1,4 miljoen banen voor laagopgeleiden nodig zouden zijn $(2005,23)$. Een dergelijk cijfer suggereert dat er een groot vraagtekort is naar laagopgeleiden, maar een blik op het werkloosheidscijfer voor de groep geeft aan dat het aantal werkzoekenden relatief beperkt is. Dan gaat het om gemiddeld genomen niet meer dan 100.0oo personen (De Graaf-Zijl et al. 2006: 3). De vraag- en aanbodverhoudingen zijn thans dus niet zozeer uit balans als het cijfer van 1,4 miljoen doet vermoeden.

Van belang is de vraag hoe deze verhouding zich gaat ontwikkelen. Drie factoren spelen hierbij een rol: de kennisintensiteit van de beroepsbevolking ten opzichte van die van de aangeboden banen, de invloed van globalisering en de omvang van de persoonlijke dienstverlening.

De eerste factor betreft de ontwikkeling waarbij de banen die erbij komen een steeds hogere opleidingsgraad vereisen, zodat de vraag naar mensen met een lage opleiding navenant zal dalen. Dit zal hun loonniveau nadelig beïnvloeden, ten gunste van dat van hoger opgeleiden. Dit zal uiteraard niet optreden wanneer het aanbod van hoger opgeleiden nog sneller zou stijgen dan de vraag naar deze categorie. Dit ligt evenwel niet in de lijn der verwachting. De algemene verwachting is daarom dat de loonverschillen zullen toenemen (Jacobs 2003; Goos en Manning 2003).

De invloed van globalisering en offshoring betreft de gevolgen die de Nederlandse arbeidsmarkt ondervindt van de toegenomen migratie van werknemers en de internationalisering van productieprocessen. De gevolgen van offshoring voor de 
arbeidsmarkt zijn nog beperkt, maar zouden voor de komende periode van tien jaar een verlies van circa 30.000 banen kunnen inhouden (European Commission 2005a: 221). In de komende jaren zal het voor wat betreft de migratie primair gaan om werknemers afkomstig uit de nieuwe EU-lidstaten. De verwachtingen over de gevolgen hiervan zijn gematigd; het СРВ verwacht enige verdringing in de sectoren waarin deze migranten gaan werken (СРВ 2006b). Ontwikkelingen in het Verenigd Koninkrijk en - vooral - Ierland laten echter grote effecten zien.

De derde genoemde factor betreft de productie van huishoudelijke diensten via de markt. Freeman en Schettkat (2005) zijn van mening dat de grotere hoeveelheid banen in de vs ten opzichte van de EU niet zozeer te maken heeft met de hoge mate van arbeidsmarktregulering in de EU, maar vooral met het verschil in de hoeveelheid huishoudelijk werk die in de vs wordt uitbesteed. Hierbij moet men denken aan koken, kinderverzorging, ouderenzorg en schoonmaken. Culturele zowel als financiële oorzaken zijn hierbij van belang. Voor wat betreft de betaalbaarheid van huishoudelijke diensten is het relevant dat de loonverschillen zowel als de netto-inkomensongelijkheid in de vs groter zijn dan in de EU. Deze beide mogelijke verklaringsgronden zijn natuurlijk niet op korte termijn overdraagbaar naar de EU. Dit neemt niet weg dat de toenemende participatie, en hiermee de toename van het aantal tweeverdieners, een potentiële vraag inhoudt naar door de markt voortgebrachte huishoudelijke diensten.

Het ziet er per saldo niet naar uit dat de drie genoemde factoren op middellange termijn de arbeidsmarkt voor laagopgeleiden een drastisch ander aanzien zullen geven. Migratie en de tendens naar een hogere kennisintensiteit zullen het loon van laagbetaalden wel neerwaarts beïnvloeden. Via de vraag naar huishoudelijke diensten kan dat weer tot extra banen leiden.

Een factor die dit arbeidsmarktsegment wel een ander aanzien heeft gegeven is de bezetting van banen voor laagopgeleiden door hoger opgeleiden. Er zijn twee belangrijke redenen waarom deze banen niet voorbehouden blijven voor laagopgeleiden. De eerste is de armoedeval. Het uitkeringsalternatief is vaak zo aantrekkelijk dat voor hen voor wie dit alternatief actueel is, de drang om een baan te vinden niet erg groot is. De tweede factor is dat er een veel beter opgeleide aanbod is. Personen die partner zijn van een kostwinner en personen met een andere bron van inkomen kunnen via een laagbetaalde baan gemakkelijk en flexibel wat bijverdienen. Waarom opteren deze hoger opgeleiden voor deze laagbetaalde banen, terwijl ze ook voor hoger gekwalificeerde arbeid in aanmerking zouden kunnen komen? De aanwezigheid van een hoofdbron van inkomen vermindert de noodzaak om hoge eisen te stellen aan het extra inkomen. Bovendien zijn laagbetaalde werkzaamheden gemakkelijk in maatwerk te verdelen: een caissière wordt niet minder productief als de werktijden kort zijn en verspreid over meerdere dagen. Dan is er hun aantrekkelijkheid voor werkgevers. Werkgevers kijken ook naar meer aspecten dan alleen het opleidingsniveau, maar ook naar sociale vaardigheden, taalbeheersing, uiterlijk en geïnteresseerdheid (De Graaf-Zijl et al. 2006: 15). Ook uit ander onderzoek blijkt dat deze sociaal-econo- 
mische vaardigheden, waaronder ook loyaliteit, betrouwbaarheid en discipline, cruciaal zijn (Hövels et al. 1999: 127).

Het is niet onaannemelijk dat als regel door hoger opgeleiden gemakkelijker aan deze criteria voldaan kan worden dan door lager opgeleiden. Studenten illustreren deze ontwikkeling. Ongeveer 70 procent van de studenten met een baan is van mening dat voor het werk dat zij doen een mavo/vmbo-niveau voldoet (De Graaf-Zijl et al. 2006: 5). Dit betekent dat studenten voor 55.0oo fte's banen voor laagopgeleiden bezetten (Steijn en Hofman 1999: 149). Het flexibele karakter van deze banen blijkt ook uit het feit dat van de 200.00o mensen die werkzaam zijn op het minimumloon, er maar 35.0oo een volledige baan hebben (RWI 2005: 50). De RWI concludeert dan ook dat het minimumloon als inkomensbasis voor werknemers "nauwelijks een rol speelt" (2005: 53).

\subsubsection{VERGROTING FEITELIJK AANBOD}

Gemiddeld genomen zijn er in de afgelopen jaren zo'n 45.0oo onvervulde vacatures per jaar geweest voor laagopgeleiden (De Graaf-Zijl et al. 2006: 5). Blijkbaar is er, gelet op dit grote aantal, te weinig aanbod om deze vacatures adequaat te kunnen bezetten. Dit kan zowel het gevolg zijn van te weinig reëel aanbod als van te weinig gevarieerd aanbod, of van aanbod dat de hierboven genoemde sociale vaardigheden en competenties mist. Waarom bieden zo weinigen van de potentiële maximale doelgroep van 1,4 miljoen mensen zich aan? Diverse verklaringen bieden zich aan: de onaantrekkelijkheid van het werk, de lage kans om aangenomen te worden (De Graaf-Zijl et al. 2006:4) en het ontbreken van een financiële prikkel. Voor kostwinners biedt een baan tegen het minimumloon geen financiële voordelen, voor alleenstaanden slechts een beperkt voordeel. De armoedeval, de afwezigheid van financiële vooruitgang bij de overgang van een uitkering naar betaalde arbeid, wordt in stand gehouden als gevolg van het inkomensbeleid gericht op de sociale minima. Omdat dit inkomensbeleid in grote mate is gedecentraliseerd naar gemeenten, is sprake van specifiek op uitkeringsontvangers gericht beleid. De voordelen voor deze groep bereiken niet degenen die tegen het minimumloon arbeid verrichten. Ofschoon de arbeidskorting dit wel doet (nl. een fiscaal voordeel voor alleen werkenden) is deze, omdat zij in Nederland van toepassing is op alle werkenden, een vrij duur instrument. Daarom kan de arbeidskorting niet zo hoog worden vastgesteld dat de armoedeval verdwijnt. De armoedeval is een wijdverspreid Europees probleem dat in de loop van de tijd alleen maar lijkt te zijn toegenomen (Galussak en Pavel 2005: 197). Vandaar dat de aandacht uitgaat naar andere instrumenten. Een andere manier om het aanbod te stimuleren is het activerend arbeidsmarktbeleid. Dit onderwerp komt elders in dit hoofdstuk aan de orde.

\subsubsection{VERGROTING VAN DE VRAAG}

Afgezien van de aspecten die aangrijpen op opleidingsniveau en sociale vaardigheden, zijn de instrumenten in deze sfeer van financiële aard. Het verlagen van 
het niveau van het wettelijke minimumloon, dan wel het verlagen van de loonkosten door het toekennen van vrijstellingen in de fiscale of premiesfeer, of door het toekennen van loonkostensubsidies, hebben gemeen dat het voor de werkgever financieel aantrekkelijker wordt om een laagopgeleide in dienst te nemen. Een combinatie van instrumenten vormt de verlaging van het minimumloon die wordt gecompenseerd door een zogenaamde Earned Income Tax Credit (EITC). Deze fiscale korting (op een afdracht) of aanvulling (als er geen afdracht is) vergt wel een inkomensafhankelijke vormgeving. Immers, als iedereen deze korting zou ontvangen, zoals dat met de arbeidskorting het geval is, is een beduidende korting financieel geen reële optie.

Met de EITC is in de vs ervaring opgedaan sinds 1975. De vormgeving is met name gefocust op gezinnen met kinderen. In de vs heeft de EITC primair een inkomenspolitieke functie. Omdat de armoedevalproblematiek in de vs minder urgent is dan in ons land, is de functie van de EITC in de vs niet zozeer arbeidsmarktpolitiek van aard. De EITC geeft inkomenssubsidie tot 40 procent van het verdiende inkomen en loopt af tot o procent in een traject van 13.000 naar 32.ooo dollar bruto-inkomen per jaar. Circa 20 miljoen mensen participeren in het schema (Meyer en Holtz-Eakin 2001: 2). De werkgelegenheidseffecten onder alleenstaande ouders zijn 'unprecedented' (155). De uitvoeringskosten zijn nogal hoog, ongeveer even hoog als de overgedragen sommen $(197,226)$. Voor de Amerikaanse arbeidsmarkt lijkt de EITC zeer succesvol (zie ook OECD 2005: 151). Ook in Denemarken is in 2003 een EITC geïntroduceerd (Pedersen 2005: 84). Anders dan in de vs was het oogmerk hier primair gelegen in de vermindering van de nadelen van de armoedeval. Beide EITC's hebben gemeen dat ze het netto-inkomen van werkenden verbeteren. Tegenover deze EITC's staat immers geen verlaging van het minimumloon. Dat wil zeggen dat het aanbod van laagbetaalde arbeidsplaatsen (anders dan door de wisselwerking met een grotere vraag hiernaar) niet primair wordt gestimuleerd. Omdat de effectiviteit van een EITC van veel factoren afhangt (aantal gewerkte uren; wel of geen partner; wel of geen kinderen; wel of geen verrekening met inkomensafhankelijke voorzieningen), vergt invoering veel maatwerk (Blundell 2006).

\subsubsection{SLOTOPMERKINGEN}

Lage loonkosten zijn een remedie voor aanbodoverschotten op de arbeidsmarkt zoals een eenvoudig vraag- en aanbodmodel leert. De vraag is of dit statische uitgangspunt ook dienstbaar is in een dynamisch perspectief. Een eerste blik op de Amerikaanse arbeidsmarkt rechtvaardigt deze vraag. Ondanks het feit dat het minimumloon in procenten van het gemiddelde loon in de vs fors lager ligt dan in ons land, is de nettoparticipatie onder laagopgeleiden er ook lager (Teulings et al. 1998: 86 en 94). Er zijn dus andere factoren dan het loonkostenniveau werkzaam, en deze factoren kunnen gezamenlijk het effect van de loonkosten domineren. 
Een evidente alternatieve benaderingslijn grijpt aan op het opleidingsniveau. Het gaat immers om de discrepantie tussen productiviteit en loonkosten. Zoals hierboven is besproken wordt de productiviteit door meer factoren bepaald dan het opleidingsniveau alleen. Naast het kennisaspect zijn immers ook sociale en communicatieve vaardigheden van belang, alsmede werkervaring.

Op elk van deze drie terreinen (kennis, vaardigheden en werkervaring) kunnen beleidsinspanningen worden ontwikkeld. Het verhogen van het opleidingsniveau zal niet gemakkelijk zijn, omdat het leerpotentieel niet bijzonder groot is (SCP 2005: 79). Het volgen van werkgerelateerde cursussen in combinatie met het verrichten van arbeid kan de interesse voor leerwegen stimuleren die zonder deze concrete samenhang moeilijk kan worden opgewekt. Dat er forse productiviteitswinsten zijn te boeken op de werkplek blijkt uit de loonsverhogingen die laagbetaalden weten te realiseren. In Amerika blijkt dat in een periode van negen jaren het gemiddelde inkomen in deze groep is verdubbeld (Andersen et al. 2005: 51). Dit effect van 'learning by doing' zou ook een verklaring kunnen vormen voor het feit dat de werkloosheid onder laagopgeleiden na de fasegewijze afschaffing van de SPAK (inz. afdrachtvermindering lage lonen) vanaf 2001, niet dramatisch is toegenomen. De tijdens het werken opgedane productiviteitsverhoging kan de SPAK-subsidie, welke gedurende diverse jaren is toegekend, ten dele, overbodig hebben gemaakt.

Het grote aantal vroegtijdige schoolverlaters in ons land, groter dan in diverse andere landen van de EU, vormt een weinig vruchtbare voedingsbodem voor de hier bepleite verhoging van de productiviteit. De basis voor een succesvol verloop van de scholingsfase wordt gelegd in de eerste levensjaren. Probleemgezinnen en gezinnen met opvoedingsproblemen bieden niet de discipline en motivering die hiervoor nodig is (Heckman en Krueger 2002: 147). Zij laten zien dat het rendement van het begeleiden van zeer jongere kinderen, en dan met name gericht op non-cognitieve vaardigheden, een veelvoud is van het rendement van het begeleiden van jongeren bij het afronden of afbreken van hun primaire vervolgonderwijs (Heckman en Kruger 2002: 91).

\subsection{ACTIVEREND ARBEIDSMARKTBELEID}

\subsubsection{INLEIDING}

Het arbeidsmarktbeleid in Nederland is de afgelopen decennia geleidelijk steeds activerender geworden. In steeds toenemende mate worden uitkeringsontvangers gestimuleerd tot herintreding op de arbeidsmarkt. Daarnaast is het arbeidsmarktbeleid van accent veranderd. In plaats van specifieke ondersteuning ligt de aandacht steeds meer bij generieke, marktconforme maatregelen. In Bijlage III wordt een overzicht gepresenteerd van het arbeidsmarktinstrumentarium en de groepen waarop dit instrumentarium van toepassing is. 


\subsubsection{REÏNTEGRATIE VAN UITKERINGSONTVANGERS}

De vraag naar het rendement van het arbeidsmarktinstrumentarium, ofwel waar de meeste winst is te behalen, is niet alleen een kwestie van de kwaliteit van het instrument, maar hangt ook af van de kenmerken van de doelgroep. Belangrijkste factoren zijn hierbij:

a. de relatieve omvang van de doelgroep,

b. de afstand van de doelgroep tot de arbeidsmarkt,

c. de uitkeringsafhankelijkheid van de doelgroep.

Ad a) Non-participatie treft men vooral aan onder laagopgeleiden, ouderen en uitkeringsontvangers. Voor de twee eerstgenoemde groepen geldt dat hun participatie lager of gelijk is aan de helft van het gemiddelde. De non-participatie van uitkeringsgerechtigden hangt af van hun verblijfsduur in uitkeringsregelingen. De participatie van vrouwen is sterk afhankelijk van de vraag of ze behoren tot de categorie laagopgeleiden en/of ouderen.

Ad b) Als de afstand tot de arbeidsmarkt groot is, zal het onevenredig meer moeite kosten om een doelgroep tot toetreding tot de arbeidsmarkt te bewegen dan voor een groep waarvoor de belemmeringen relatief gering zijn.

Ad c) Als men een uitkering ontvangt heeft reïntegratie een dubbel profijt. Enerzijds versterkt men het financiële draagvlak, anderzijds wordt het beroep op de financiële middelen van de publieke sector verkleind.

Kijken we naar de aantallen, dan blijkt dat er bijna een miljoen personen zonder betaald werk of uitkeringen zijn. Velen hiervan zijn vrouwen (szw 2006: 41). Er zijn in Nederland ongeveer 630.00o vrouwen die prioriteit toekennen aan de zorg voor het gezin en dat niet verenigen met een betaalde baan. Beschikbaarheid van betaalbare en kwalitatief goede kinderopvang zou onvoldoende soelaas bieden om deze groep tot participatie te bewegen omdat, aldus het SCP, de zorgrol vooral wordt bepaald door de opvattingen over het opvoeden van kinderen. Maar zelfs als deze factor niet zou spelen, dan nog gaat het om laagopgeleiden. Hoogopgeleide vrouwen werken voor het overgrote deel. De afstand van deze groep tot de arbeidsmarkt is derhalve tweeledig bepaald (RWI 2006: 20, 35-37).

\section{Tabel 6.2 Uitkeringsontvangers WW, Bijstand en WAO, 2006}


De groep uitkeringsontvangers die in beginsel voor reïntegratie in aanmerking komt bestaat uit deelnemers aan de ww, arbeidsongeschikten en de bijstandspopulatie.

Bij dit aantal passen enkele kanttekeningen.

Ten eerste zijn niet alle uitkeringsgerechtigden sollicitatieplichtig. Daarnaast meent Divosa dat zelfs de helft van de bijstandspopulatie "naar verwachting geen perspectief heeft op regulier werk" (Divosa 2006:7). Voorts zijn er de volledig arbeidsongeschikten van wie ongeveer de helft weer geheel of gedeeltelijk herstelt (SER 2004, bijl. 8: 189). Aldus blijft er van 1,5 miljoen personen uit de tabel per saldo een groep van ongeveer 1 miljoen uitkeringsontvangers over die kunnen profiteren van begeleiding en ondersteuning bij reïntegratie.

Naast de doelgroep van personen zonder inkomen en uitkeringsontvangers zijn er ook nog de laagopgeleiden en ouderen met een uitzonderlijk lage participatie. De laagopgeleiden kwamen al ter sprake in paragraaf 6.3; voor de ouderen geldt dat het beleid er primair op is gericht de incentives om uit te treden te neutraliseren. De groep uitkeringsontvangers blijkt dus niet alleen relatief omvangrijk, maar bovendien ook zeer aantrekkelijk om te reïntegreren, vanwege de vergroting van het draagvlak voor de overheidsfinanciën, maar ook vanwege de vermindering van het beroep daarop. Daarom zullen hieronder met name de reïntegratiemogelijkheden van deze groep worden bezien.

Wanneer een uitkeringsontvanger onvoldoende meewerkt aan het vinden van een passende baan, staat de overheid het middel van sanctioneren ter beschikking. In Nederland wordt daar, hoewel in toenemende mate, in relatief weinig gevallen gebruik van gemaakt. Bovendien zijn de consequenties bescheiden. Iemand moet het echt erg bont maken, wil de uitkering niet langer toegekend worden. Het sanctiebeleid wordt belemmerd door een moeilijke bewijsvoering. Uiteindelijk gaat het om gedragsuitingen, en degenen die de kunst beheersen de negatieve gedragsuitingen niet te vertonen, zullen moeilijk kunnen worden gesanctioneerd. Bovendien zullen werkgevers geen voorkeur hebben voor werknemers die door de dreiging van een sanctie solliciteren.

Een wellicht effectievere wijze van activering is een voortdurende actieve bemoeienis met de reïntegratie-inspanningen. Veel landen kennen daarom de figuur van een reïntegratieadviseur die voortdurend de vinger aan de pols houdt. In ons land heeft het UWV voor dit doel de reïntegratiecoach ingevoerd. Zelfs het houden van uitsluitend een intakegesprek, heeft, ten opzichte van de situatie van afwezigheid van enige vorm van interventie, al een zeer substantieel effect op het werkloosheidsniveau (OECD 2005: 182). Dit is ook een van de achtergronden van de zogenaamde sluitende aanpak, die in het kader van de Employment Strategy van de EU is ondernomen, en waarmee wordt beoogd dat elke uitkeringsontvanger in de eerste periode van de inactiviteit een reële ondersteuning krijgt aangeboden. Natuurlijk is zo'n voortdurende begeleiding kostbaar, temeer daar een grote vaardigheid gewenst is om in de individuele gevallen met passende reactie te komen. Onnodige twijfels over de effectiviteit van het actief arbeidsmarktbe- 
leid (zie hieronder) verhinderen echter dat in deze sfeer grote investeringen worden gedaan.

Het scala van instrumenten dat van toepassing is op reïntegratietrajecten is zeer ruim. Het voeren van een gesprek is de lichtste vorm, terwijl het volgen van een langdurige opleiding dan wel het aanbrengen van (kostbare) werkplekaanpassingen aan de andere kant van het spectrum staan. Daartussen bevinden zich sollicitatiecursussen, loopbaanoriëntaties, vormen van empowerment, werkervaringstrajecten en revalidatietrainingen. Het is van belang dat de keuze aansluit bij de wensen en mogelijkheden die de uitkeringsontvanger zelf ziet. Die wensen moeten dan wel werkgeoriënteerd zijn. De waarborg hiervoor is te vinden door de keuze van een reïntegratiebedrijf dat wordt afgerekend op resultaat. Een effectieve vorm om de persoonlijke inbreng mogelijk te maken is het sinds enkele jaren in ons land werkzame instrument van de individuele reïntegratieovereenkomst (IRO). Een uitkeringsontvanger maakt dan zelf de keuze voor een reïntegratietraject of -bedrijf, en het betreffende bedrijf ontvangt hiervoor een vergoeding, die deels afhankelijk is van de relatieve prestaties die het levert om betrokkene ook daadwerkelijk een baan te doen vinden. Een plaatsingsresultaat telt wanneer de duur ervan ten minste zes maanden beloopt. Een andere mogelijkheid is het aangaan van een contract tussen de uitkeringsontvanger en de uitvoeringsinstantie. Ofschoon zo'n contract een zekere eenzijdigheid kent (tenslotte kan de echte tegenprestatie, namelijk het beëindigen van de uitkering vanwege het vinden van een nieuwe betaalde baan, bezwaarlijk met 1oo procent zekerheid van de uitkeringsontvanger worden verlangd), werkt dit in de praktijk wonderwel (Sol en Westerveld 2005: VI).

\subsubsection{RECENTE ONTWIKKELINGEN}

Als uitvloeisel van de vele hervormingen in de sociale zekerheid in ons land, heeft ook het reïntegratiebeleid een aantal veranderingen ondergaan. De grootste veranderingen betreffen die uit de Wet structuur uitvoering werk en inkomen (SUWI) uit 2001, die de uitvoering van de werknemersverzekeringen regelt. Deze wet gaat uit van een uitvoering van de reïntegratie van uitkeringsontvangers op basis van uitbesteding aan private organisaties. Vervolgens is in het verlengde hiervan besloten tot een volledige resultaatfinanciering (SZW 2002).

Voorts heeft ook de sluitende aanpak meer accent gekregen: een aanpak waarbij aan allen die voor een werkloosheidsuitkering in aanmerking komen, ondersteuning wordt geboden om weer terug te keren in het arbeidsproces. De voorschriften met betrekking tot de inhoud van die aanpak laten ruimte voor variatie. Naar aanleiding van de herkeuringsoperatie van WAO'ers, van wie de mate van arbeidsgeschiktheid opnieuw wordt beoordeeld in het licht van het nieuwe zogenaamde Schattingsbesluit, heeft de sluitende aanpak voor deze groep geleid tot een zodanig aanbod van ondersteuning als nodig is om een reële kans te verkrijgen op een baan c.q. op urenuitbreiding als men reeds over een deeltijdbaan beschikte. Ook de invoering van de nieuwe wet voor gedeeltelijk arbeidsgeschikten en volledig 
arbeidsongeschikten, de WIA, die voor de nieuwe instroom met ingang van 2006 de WAO vervangt, impliceert een versterking van de rol van de reïntegratie. Het onderdeel van de WIA dat de gedeeltelijk arbeidsgeschikten betreft, kent immers een uitkeringsverlaging voor degenen die niet de helft van hun resterende verdiencapaciteit benutten via een betaalde baan. Dit zal een belangrijke stimulans vormen voor het vinden van zo'n baan en bijgevolg zal de belangstelling voor het verkrijgen van hulp hierbij groeien.

Een aanzienlijk deel van de middelen die de overheid heeft gereserveerd voor reïntegratie, staat ter beschikking van de gemeenten. Het gaat hierbij om een bedrag van ruim 1,5 miljard euro, waarvan een aanzienlijk deel nog door gemeenten is vastgelegd in gesubsidieerde arbeid (WIW/ID) (SZW 2005a). Een deel van deze middelen zouden de gemeenten via aanbesteding aan private reïntegratiebedrijven ter inkoop van trajecten moeten aanwenden. Tegen dit voorschrift bestonden bezwaren, omdat een vrije beschikbaarheid de gemeenten de mogelijkheid verschaft dit geld in te zetten voor andere vormen van activering dan via reïntegratie naar reguliere banen. Bovendien vergt de verplichte aanbesteding een leerproces; met name kleine gemeenten zijn niet zonder meer in staat om te profiteren van de mogelijkheden die de reïntegratiemarkt biedt. Ook het succesvol contracteren van een reïntegratiebedrijf veronderstelt ervaring en expertise. Door samenwerkingsverbanden zou geïnvesteerd kunnen worden om de kennis van de markt te vergroten en het optimaal benutten ervan mogelijk te maken. Door de verplichting tot aanbesteding te heroverwegen zijn potentiële voordelen van marktwerking in de sfeer van diversiteit van producten, innovatie en kostenbesparing door concurrentie, verloren gegaan. Daar komt bij dat private reïntegratiebedrijven naar de mening van de cliënten op de relevante aspecten telkens beter (in een tweetal gevallen evengoed) scoren dan gemeenten of UWV (RWI 2005a: 9).

Ook de openbare aanbesteding van reïntegratietrajecten voor ontvangers van uitkeringen uit hoofde van werknemersverzekeringen op basis van volledige resultaatfinanciering staat op enkele onderdelen ter discussie. Toch zijn er vele voordelen. Zo is als gevolg van resultaatfinanciering de gemiddelde trajectprijs gedaald van 5000 naar 3000 euro, een besparing van niet minder dan 40 procent (zie tabel 6.4 bij Borea 2006).Ondanks deze aanmerkelijke verlaging van de trajectprijs, is de uitstroom van deelnemers naar reguliere banen met 30 procent gestegen (SZW 2006c: 3). Per plaatsing zijn de kosten dus meer dan gehalveerd. Natuurlijk heeft deze drastische verandering consequenties gehad voor de reïntegratiemarkt en de uitvoering. De overgang van een contract op basis van te leveren inspanningen naar te leveren resultaten stelt veel hogere eisen aan reïntegratiebedrijven die daar wisselend op hebben gereageerd. Voorts is er de vraag of resultaatfinanciering ook voor kleinere producten doelmatig is. Als iemand op slechts een klein onderdeel bijgespijkerd moet worden, ligt het niet in de rede de financiering van een relatief bescheiden dienstverlening afhankelijk te maken van het feit of betrokkene vervolgens wel of niet een baan vindt. 
Een andere kwestie betreft de zogenaamde afroming. Hierbij wordt gedoeld op de omstandigheid dat reïntegratiebedrijven die een contract afsluiten voor een groot aantal cliënten, alleen de meest kansrijken een traject zullen aanbieden. Voor de minder kansrijken is een traject of relatief kostbaar of is de kans op plaatsing geringer, zodat onder een stelsel van resultaatfinanciering deze kosten niet goedgemaakt zullen worden. Het winstoogmerk leidt ertoe dat kansarmen het nakijken hebben. Het gevaar bestaat dan dat alleen de meest kansrijken worden geïntegreerd, terwijl juist deze groep wellicht ook zonder reïntegratietraject de overgang naar de arbeidsmarkt had kunnen maken. Afroming zou dan leiden tot een weinig rendabele inzet van middelen. Afroming veronderstelt dat een reïntegratiebedrijf aan de poort kansrijken van kansarmen kunnen onderscheiden. Maar als het ene reïntegratiebedrijf dat kan, kan de concurrent dat ook. Derhalve zal in een systeem van openbare aanbesteding de prijs voor dit type contracten afnemen, waardoor er geld overblijft voor de groepen die meer inspanning vergen. Beter nog is het wanneer die kennis om kansarmen van kansrijken te onderscheiden, door de aanbesteder wordt benut om op die manier homogene groepen samen te stellen van elk van beide categorieën. De moeilijkere groep kan dan voor een hoger bedrag worden aanbesteed dan de gemakkelijker plaatsbaren.

Deze oplossing is inmiddels toegepast op het derde punt van kritiek op resultaatfinanciering, namelijk dat door af te rekenen op resultaat, scholing de facto niet meer tot de mogelijkheden zou behoren. Inmiddels is een zogenaamd scholingsprotocol opgezet op grond waarvan cliënten kunnen worden geselecteerd voor wie scholing behulpzaam zou zijn voor het vinden van de weg naar de arbeidsmarkt. De voorkeur voor scholing stamt uit de tijd van vóór de marktwerking, waarbij reïntegratiebedrijven werden gecontracteerd voor het leveren van trajecten, ongeacht de vraag of deze wel of niet zouden leiden tot een baan. Scholing is dan een aantrekkelijke bezigheid, de activiteit wordt algemeen als nuttig ervaren, terwijl de kostbaarheid ervan omzetvergrotend werkt. Met nut wordt in dit verband niet op effectiviteit gedoeld. De effectiviteit van scholing van werkzoekenden is immers dubieus. Het algemene beeld, dat ook naar voren komt in buitenlandse studies, is dat reguliere reïntegratietrajecten niet alleen goedkoper maar ook effectiever zijn dan scholing (szW 2004a: 4 en 5; De Koning et al. 2004: 70-71; Kluve 2006: 27).

\subsubsection{DE EFFECTIVITEIT}

Over de effectiviteit van het activerend arbeidsmarktbeleid is veel discussie. Intuïtieve opvattingen hierover zijn zelden eensluidend. Naast het meten van de resultaten is er vervolgens de vraag over de invloed van de reïntegratietrajecten op die resultaten. Met andere woorden, als men niet weet hoeveel personen er aan de slag zouden zijn gegaan zonder reïntegratie-inspanningen, blijft men in het duister tasten naar de effectiviteit van dit beleid. Er zijn diverse pogingen ondernomen om deze zogenaamde netto-effectiviteit te meten (TNO: 2005). 
Het CPB is kritischer op het arbeidsmarktbeleid dan op een negatieve manier van interventie, te weten sancties. Een intensivering van het sanctiebeleid met 1 procent zou een verhoging van het reïntegratie-effect met 3 procent tot gevolg hebben (CPB 2006: 101). Vanuit financieel opzicht is er wat te zeggen ten voordele van sancties in vergelijking met reïntegratie-instrumenten. Immers, sancties vergen, afgezien van de uitvoering, geen uitgaven en leveren zelfs geld op. Maar vanuit arbeidsmarktperspectief ontbreken die voordelen. Een sanctionering is alleen effectief als dreiging; het door het СРВ geraamde werkgelegenheidseffect ontstaat alleen omdat men voor de dreiging zwicht. Het betalen van de sanctie alleen draagt immers niet bij aan de participatie. Dat het de aansporing is die effect sorteert wordt ook bevestigd door de uitvoeringspraktijk in een aantal Europese landen en de literatuur (SEOR 2006: 76).

Hierboven zagen we ook al dat een aansporing door het enkel voeren van gesprekken tot een substantiële vermindering van de inactiviteit leidt. In het kader van de 'work first'-benadering verlangen gemeenten een tegenprestatie van aanvragers van een bijstandsuitkering. Deze vraag alleen al leidt ertoe dat 17 procent van de aanvragen wordt ingetrokken (Divosa 2006: 11). Een positieve aansporing, waarbij de vinger aan de pols wordt gehouden en bovendien ook nog reïntegratiehulp wordt geboden, moet daarom effectiever zijn dan sancties alleen. Het ontbreken van adequate pogingen om een baan te vinden is immers niet altijd een kwestie van onwil alleen. Zou dat wel zo zijn, dan zou het niet toekennen van uitkeringen de aangewezen weg zijn. Veel mensen met een eenzijdige werkervaring en een beperkt opleidingsniveau hebben niet de intellectuele veerkracht om zelf een geheel nieuwe start te maken op de arbeidsmarkt. Wordt de inactiviteit voorafgegaan door ontslag of gedeeltelijke arbeidsongeschiktheid, dan kan dat al een reden zijn voor twijfels over de eigen daadkracht, die eerder moeten worden gecompenseerd door ondersteuning dan door sanctionering. Een reïntegratiebeleid dat als onmisbaar kenmerk heeft dat men niet met rust gelaten wordt zolang het zoekgedrag niet tot resultaat heeft geleid, moet daarom effectiever zijn dan een sanctiebeleid alleen (SEOR 2006: 78).

Algemene uitspraken lijken wel mogelijk wanneer deze worden gebaseerd op datgene wat aan materiaal is verzameld in de verschillende landen die veel ervaring hebben met dit type beleid. Recentelijk heeft SEOR een veelomvattende literatuurstudie verricht waarin is geprofiteerd van de vele beschikbare informatie (SEOR 2005). De conclusie die SEOR hieruit trekt is dat actief arbeidsmarktbeleid als effectief moet worden beschouwd (SEOR 2005: 85). Maar er zijn verschillen. Voor incentives (sancties en subsidies) en interventies (zoals bemiddeling) is het beeld met betrekking tot de effectiviteit duidelijk positief. Scholing daarentegen levert een gemengd beeld op, terwijl de creatie van additionele banen in de publieke sector een negatieve effectiviteit heeft. Deze zo uiteenlopende waardering voor de drie onderscheiden vormen (incentives en interventies; scholing en training; gesubsidieerde banen) stemt geheel overeen met een na het SEORrapport verschenen literatuuroverzicht. Hierin wordt voorts ook geconcludeerd dat meer dan de arbeidsmarktinstituties en de conjuncturele omstandigheden, de 
gekozen vormen van arbeidsmarktbeleid bepalend zijn voor de effectiviteit (Kluve 2006: 27,1).

De betekenis van een activerend arbeidsmarktbeleid heeft er ook toe geleid dat de OESO de aanvankelijke uitsluitend op marktconformiteit geïnspireerde aanbevelingen uit de OECD Jobs Studies heeft aangevuld ten gunste van deze vormen van beleid. Het activerend arbeidsmarktbeleid vormt ook de hoofdzaak van de Europese Werkgelegenheidsstrategie (Bradley en Stephens 2007). Layard (2005: 173) concludeert dat landen die hun uitkeringsregime combineren met een activerend arbeidsmarktbeleid een veel lagere werkloosheid vertonen.

\subsubsection{SLOTOPMERKINGEN}

Het Nederlandse arbeidsmarktbeleid, als we daar het voorwaarden scheppende beleid niet toe rekenen, kent als belangrijkste beleidsinstrumenten subsidies, sancties en interventies in de vorm van reïntegratietrajecten, en door de overheid gecreëerde banen voor groepen die niet (onmiddellijk) voor een reguliere baan in aanmerking kunnen komen. Subsidies komen thans alleen nog voor bij gemeenten. In het verleden evenwel hebben vele subsidieregelingen bestaan. Gerichte subsidies ontmoeten vele bezwaren (criteria voor vaststelling doelgroep, bureaucratische rompslomp bij aanvragen, onbillijkheden bij lange duur, twijfels over permanentie) die vervallen bij een generieke vormgeving. Deze vorm is evenwel relatief erg duur, omdat ook degenen die zonder deze subsidie een baan zouden hebben gehad ervan profiteren.

Gelet op de vele wisselingen in het instrumentarium van het arbeidsmarktbeleid lijkt het wenselijk om de huidige focus op reïntegratietrajecten te bestendigen. Veranderingen in beleid doen afbreuk aan de geloofwaardigheid, belasten de uitvoering en verhinderen dat verbeterprocessen kunnen worden ontwikkeld. Vanwege de effectiviteit die uit vrijwel alle onderzoeken blijkt, zou het sanctiebeleid kunnen worden geïntensiveerd. Voor degenen die oneigenlijk gebruikmaken van sociale uitkeringen, omdat voor hen een betaalde baan een concreet alternatief vormt, zal zo'n intensivering zeker effectief zijn. Voor het merendeel van de uitkeringsontvangers die te maken hebben met een zekere afstand tot de arbeidsmarkt, zal een sanctiebeleid pas echt effectief zijn, wanneer het onderdeel vormt van een reïntegratiebeleid dat ook diensten en stimulansen bevat. Recent onderzoek, gebaseerd op ervaringen in Denemarken waar geen enkele mate van vrijblijvendheid is als het gaat om het na verloop van enige tijd participeren in reïntegratietrajecten, toont dat dit type beleid een effect heeft dat vergelijkbaar is met dat van beëindiging van de uitkering na verloop van die tijdspanne. Dit laat zien dat reïntegratietrajecten hoogstwaarschijnlijk zelfs de meest effectieve beleidsvorm zijn, mits het commitment waarmee de verplichting om aan deze trajecten deel te nemen, ook echt stevig is (Geerdsen 2006: 749).

Bij de reïntegratietrajecten doen zich actuele keuzemogelijkheden voor, zowel ten aanzien van de inhoud (meer of minder scholing), de inspraak van betrokke- 
nen (zoals dat met de IRO is geregeld), de uitvoeringsmodaliteiten (wel of niet met inschakeling van particuliere organisaties) en de aard van het gewenste product (een contract over inspanningen of over resultaat). Vanuit het veld, de cliënten, en de politiek wordt veel aandrang uitgeoefend om reïntegratietrajecten in te vullen met scholing, maar veel onderzoek betwijfelt de effectiviteit ervan. Positief zijn de onderzoeken wel over de inspraak die men de uitkeringsontvanger toekent, hetzij via medebeslissing, hetzij via een contract. Bij inschakeling van het particuliere bedrijfsleven kan men profiteren van de diversiteit aan diensten die reïntegratiebedrijven bieden, en ook van de innovatie en concurrentie die deze laten zien. Daarvoor is dan wel nodig dat de aanbesteding niet leidt tot zogenaamde bulkcontracten waarbij een meer persoonlijke benadering erg moeilijk realiseerbaar wordt. Door voor relatief kleine groepen, bij voorkeur van homogene samenstelling, met enige regelmaat en met inbegrip van regionale spreiding, aan te besteden, kan optimaal van het pluriforme aanbod worden geprofiteerd.

De overstap naar resultaatfinanciering heeft zowel de gemiddelde trajectprijs fors verlaagd als de effectiviteit substantieel verhoogd. Mogelijk heeft deze overstap de prijsconcurrentie te veel accent gegeven waardoor er contracten zijn aangeboden tegen een prijs die onvoldoende aandacht mogelijk maakt voor alle deelnemers. Als dat zo is, is dat reden om deze onvolkomenheden op te ruimen, maar niet om terug te keren naar een situatie waarbij terugkeer naar de arbeidsmarkt meer een bijkomstigheid was dan een doel. Zo meent ook SEOR dat uitkeringsinstellingen "dienen te sturen op kosten en netto-effectiviteit" (SEOR 2005: 89).

\section{$6.5 W W$}

\subsubsection{INLEIDING}

De werkloosheidswet biedt bescherming tegen inkomensverlies als gevolg van werkloosheid. Ofschoon de wW zowel in vergelijking tot werkloosheidsregelingen in het buitenland (zie SzW 2006: fig. 2.3) als in vergelijking tot het financiële beslag van andere sociale uitkeringen geen opvallende plaats inneemt, is ze toch voortdurend onderwerp van discussie. Ten eerste is er de verwachting dat de bijdrage die de ww levert aan een activerend sociale zekerheidsstelsel, belangrijk kan worden vergroot. Ten tweede speelt de ww een rol in de discussie over het flexibeler maken van de arbeidsmarkt; ontslagbescherming en wW vormen tot op zekere hoogte communicerende vaten. Ten derde is er de relatie met de zogenaamde nieuwe risico's, in welk verband de vraag opkomt of de ww niet kan worden benut voor het opvangen ervan (WRR 2006: 158). Bovendien is het financiële element nooit ver uit de buurt. In tijden van laagconjunctuur, wanneer de budgettaire middelen toch al krap zijn, loopt het volume in de ww op, waarmee een extra financiële tegenvaller ontstaat. Zo liep het beroep op de ww tussen 2001 en 2005 op van ruim 170.000 naar ruim 290.000 personen.

Door het huidige kabinet zijn er vele veranderingen aangebracht in de ww. Deze betreffen niet alleen hoogte en duur, maar ook de toetredingsvoorwaarden, de 
vrijstelling van de sollicitatieplicht, de zogenaamde verwijtbaarheidstoets, alsook de reïntegratiemogelijkheden vanuit de ww. Het gaat onder meer om het volgende.

- De vervolguitkering is vervallen met ingang van augustus 2003 (werklozen van voor die datum hadden na afloop van hun loongerelateerde uitkering ook nog recht op een vervolguitkering van twee jaren ter hoogte van 70 procent van het minimumloon, en voor 57,5-jarigen was de duur zelfs 3,5 jaren).

- De maximale duur van de uitkering wordt gereduceerd van 60 naar 38 maanden.

- Om tot de Ww te kunnen toetreden moet men 4 (was 3) van de 5 voorafgaande jaren hebben gewerkt, alsook 26 van de voorafgaande 36 (was 39) weken.

- Wie niet aan de hierboven genoemde jareneis voldoet, maar wel aan de wekeneis ontvangt een loongerelateerde uitkering van 3 maanden (was 6 maanden uitkering van 70 procent minimumloon). Gedurende de eerste 2 maanden is de uitkering 75 procent.

\subsubsection{KNELPUNTEN IN DE WW}

De belangrijkste wijziging in de ww is ongetwijfeld de verkorting van maximale duur van 5 naar ruim 3 jaren. Met deze maatregel wordt met name beoogd het gebruik van de ww als middel van vervroegde uittreding tegen te gaan. Personen, ouder dan 57,5 jaar die ontslagen werden, konden onder het oude regime van de ww genieten tot het bereiken van hun pensioengerechtigde leeftijd. In de leeftijdscategorie van 60 jaar en ouder is circa 15 procent werkzaam, de overigen zitten in de vut/prepensioen, of, wat nog iets vaker voorkomt, in de WAO of de WW (SER 2005a: 202, zie ook 276). Deze wijziging in de WW past derhalve in het beleid gericht op het verhogen van de participatie van ouderen, welke verhoging in het licht van de vergrijzing hoogst welkom is.

Vanuit dit gezichtspunt heeft de wW een zekere ambivalentie. De inkomensbescherming die de WW aan ontslagenen biedt, stelt hen in staat om op zoek te gaan naar een baan die aansluit bij hun kwaliteiten. Zonder deze inkomenszekerheid zouden ontslagenen zich genoodzaakt kunnen zien om veel minder kieskeurig te zijn. Het onvoldoende benutten van het (kwalitatieve) arbeidspotentieel zou schadelijk zijn voor de economische ontwikkeling. Een zo hoog mogelijke uitkering zou dit risico verminderen. Echter, als er geen inkomensachteruitgang zou zijn, zou dit niet alleen de druk wegnemen om te opteren voor een inferieure baan, maar ook voor een passende baan. Dit gevaar van moral hazard kan worden tegengegaan door een effectief zoekgedrag op te leggen. Dit is in essentie de kern van het Deense arbeidsmarktmodel. Een hoge werkloosheidsuitkering wordt gecombineerd met actief beleid om de uitkeringsontvanger weer aan een baan te helpen. ${ }^{1}$ Dit model veronderstelt de aanwezigheid van:

- een effectief reintegratiebeleid met evidente sancties op gebrek aan medewerking,

- een zodanig arbeidsethos en sociale controle dat die medewerking er in praktisch alle gevallen ook is, en 
- een voorraad van banen (die per definitie een publieke voorziening inhoudt) om bij een tekort aan banen (in het algemeen of voor bijzondere groepen) toch de herintreding op de arbeidsmarkt te kunnen realiseren.

Aan deze voorwaarden lijkt in Nederland (nog) niet ten volle te zijn voldaan. Vandaar dat het probleem van moral hazard in Nederland serieus de aandacht verdient. Empirische studies bevestigen dit. Veertig procent van de werklozen in Nederland vertoont te weinig zoekgedrag of ziet af van passend werk. Een langere uitkeringsduur leidt, zo blijkt uit onderzoek voor meerdere landen waaronder Nederland, tot een hogere werkloosheid (CPB 2004a: 12 en 14). Moral hazard kan ook de werkgever betreffen. Met name bij cyclische werkloosheid is er het gevaar dat werkgevers het risico van cyclische patronen in de economische bedrijvigheid via tijdelijke werkloosheid afwentelen op de wachtgeldfondsen.

Afgezien van een geringe beschikbaarheid van banen (hetgeen tijdelijk een belemmerende factor kan vormen; op lange termijn volgt de werkgelegenheid het aanbod) en een suboptimaal zoekgedrag, kan herintreding ook belemmerd worden door een onvoldoende mate van employability. Werknemers die een verouderde vakkennis hebben of actuele werkervaring missen, zullen minder gemakkelijk een baan vinden tegen het oude loon, dan werknemers die juist wel veelgevraagde kwaliteiten bezitten. De werkgever zou er daarom op aangesproken kunnen worden de employability van het personeel op niveau te houden. Door de kosten van de ww te verhalen op de werkgever krijgt deze belang bij een korte duur ervan. Moeilijkheid van deze benadering is dat ook werkgevers van wie de werknemers wel employable zijn, geconfronteerd kunnen worden met de noodzaak van ontslagen. Premiedifferentiatie zou dan moeilijk te rechtvaardigen zijn. Bovendien grijpt premiedifferentiatie niet aan op moral hazard van de zijde van de werknemers.

Een andere indicatie voor het onbedoeld gebruik van de wW als gevolg van moral hazard, kan gevonden worden in de zogenaamde herhalingswerkloosheid. De aanspraak die men heeft op de ww kent een onbeperkte gebruikswaarde. Wie eenmaal voldaan heeft aan de eis van 3 uit 5 jaren te hebben gewerkt, en vervolgens op basis van halfjaarlijkse contracten aan de slag gaat, kan in theorie elk jaar gebruikmaken van een loongerelateerde ww-uitkering. Per jaar immers wordt dan voldaan aan de wekeneis.

Door SEOR is onderzoek verricht naar het gecumuleerde gebruik van de WW. Daartoe is een panel van 65.000 personen over een periode van twaalf jaren gevolgd. Vervolgens heeft men op basis van dit bestand ook levenslopen gesimuleerd. Men concludeert dat over de gehele levensloop bezien ongeveer 40 procent van de bevolking een of meerdere malen van de ww heeft gebruikgemaakt. Tien procent hiervan (dus 4 procent van de bevolking) legt beslag op 40 procent van de WW-uitkeringen (SEOR 2005a: III-IV). Als het gebruik van de WW volkomen gelijk gespreid was, zou op levensloopbasis i procent van de werknemers beslag leggen op 1 procent van de $\mathrm{WW}$-uitkeringen. Waar 40 procent al opgaat aan de 4 procent veelgebruikers, blijft voor de resterende 96 procent dus nog 60 procent 
over. De 4 procent veelgebruikers profiteren derhalve met een factor 16 meer van de ww dan de 96 procent overige werknemers. In tijd gemeten legt iets meer dan tien procent beslag op de helft van de Ww in uitkeringsjaren (SEOR 2005a: IV). Door deze uitkeringsjaren te relateren aan het aantal loontrekkers in arbeidsjaren in dezelfde periode van twaalf jaren, 1989-2000, blijkt dat veelgebruikers per jaar 21 procent doorbrengen in de $\mathrm{WW}$, met andere woorden op lifetimebasis (van $18-65$ jaar), tien jaren. ${ }^{2}$ Het is de vraag hoe deze periode geïnterpreteerd moet worden. Als het gaat om personen met een grote afstand tot de arbeidsmarkt kan het zijn dat men enerzijds is aangewezen op banen met een tijdelijk karakter en anderzijds dat men niet zo succesvol is in het vinden van dergelijke banen dat er sprake is van een ononderbroken loopbaan. In dat geval zou de ww een middel vormen om deze personen toch voor de arbeidsmarkt te behouden. Dit middel is dan wel relatief duur, en niet zozeer een smeermiddel maar veeleer een hulpmotor om een slecht geolied functioneren op de arbeidsmarkt in stand te houden.

\subsubsection{ACTIVERING}

Moral hazard in de ww kan dus verschillende vormen aannemen, en zich effectueren bij de instroom naar de ww, bij de uitstroom en bij de herhaalde instroom. Dit onderscheid is van belang, omdat elk type moral hazard om een andere beleidsreactie vraagt. Vanuit het oogpunt van flexibiliteit is een hoge uitstroom wenselijk. Als deze verzekerd is, maakt een hoge instroom en zelfs ook een hoge herhaling niet zoveel uit. Helaas stelt de uitstroom teleur. Van degenen die instromen in de wW verlaat ongeveer de helft de ww vanwege het hebben van werk. Dit ligt voor alle leeftijdscategorieën ongeveer gelijk, met uitzondering van de hoogste leeftijdscategorie waarvoor werkhervatting minder vaak voorkomt. Ook voor de verblijfsduur in de ww zijn de verschillen niet groot. De gemiddelde verblijfsduur voor de leeftijdscategorie 25-54 jaar is ongeveer een half jaar (SER 2005a: 168). Recent onderzoek toont aan dat werkloosheid geen blijvend effect heeft op de kans op betaalde arbeid. Waar het arbeidspotentieel niet wordt benadeeld, geldt dat wel voor het verdienpotentieel; hoe langer men werkloos is, hoe groter de kans dat het loon achterblijft bij het oude loon (OsA 2006: 54). Het is dus zaak deze verblijfsduur zo kort mogelijk te houden.

Om de uitstroom te bevorderen zijn de afgelopen jaren vele maatregelen getroffen. Ondanks deze inspanningen was de uitstroomkans vanuit de WW naar een betaalde baan in 2002 lager dan tien jaar eerder. (SER 2005a: 203), dit als gevolg van de conjuncturele neergang. De verwachting is derhalve gerechtvaardigd dat deze kans de komende jaren zal verbeteren. Daarvoor is het dan wel noodzakelijk dat de intensivering en de verbeteringen in het reïntegratiebeleid niet aan slijtage onderhevig zijn. De sluitende aanpak, de intensieve begeleiding, de resultaatfinanciering en het stringentere sanctiebeleid zullen daartoe de aandacht moeten blijven ontvangen. 


\subsubsection{SPAREN VOOR DE WW}

Om het onbedoelde gebruik van de ww door moral hazard te voorkomen, zou de WW kunnen worden omgevormd van een werknemersverzekering naar een stelsel van individuele rekeningen. In een simpele versie zouden de huidige wWpremieafdrachten gestort kunnen worden op de rekening van degenen voor wie de premieafdracht plaatsvindt. Een verblijf in de ww wordt dan gefinancierd door trekkingen op deze persoonlijke rekening. Wie een batig saldo heeft kan dit benutten aan het einde van de loopbaan, een negatief saldo moet worden aangezuiverd door of wordt kwijtgescholden aan betrokkenen. Ook kan het bereiken van een negatief saldo ertoe leiden dat men een beroep moet doen op de bijstand (Rezwani \& Hendrix 2002). In zo'n variant zullen de meeste mensen geld overhouden, een klein percentage zal (veel) geld tekortkomen. Het niet aanzuiveren, zeker wanneer het gaat om minder draagkrachtigen, zal op inkomenspolitieke en praktische bezwaren stuiten. Bij kwijtschelding vervalt een belangrijk voordeel van een spaarvariant, omdat gedragseffecten dan beperkt zullen blijven tot de groep die een beroep doet op de ww, maar slechts in die mate dat er een zeker positief saldo op de rekening blijft staan. Het gaat hierbij om ongeveer 20 procent van de verzekerde populatie (SEOR 2005a: III). ${ }^{3}$

Voor de grote groep die geld overhoudt, ligt het in de rede het gespaarde bedrag aan het eind van hun loopbaan beschikbaar te stellen. Wanneer dit bedrag wordt aangewend om vervroegd uit te treden, wordt het oogmerk van hogere participatie onder ouderen voor deze personen niet bereikt. Dit is een ander nadeel van de spaarvariant. Tenzij een negatief saldo wordt kwijtgescholden, betekent deze spaarvariant het einde van de solidariteit in de ww. Het opzetten van een verplichte spaarregeling, die slechts voor een klein percentage gunstige gedragseffecten kan sorteren, lijkt een omslachtige route om de solidariteit in de ww te beëindigen. Wanneer personen met een negatief saldo in de bijstand terechtkomen, zal bovendien het solidariteitsaspect langs een achterdeur weer binnenkomen. Het alternatief van het afschaffen van de ww waarbij de keuze tot verzekeren van het werkloosheidsrisico wordt overgelaten aan de burgers, verdient dan afweging.

Een wat andere variant is de spaarvariant te beschouwen als een employabilityverzekering. De besparingen kunnen dan ook worden aangewend voor scholing, een sabbatical of voor het ontwikkelen van een eigen bedrijf. Zo'n verzekering biedt ook perspectieven voor een betere verdeling van werk en zorgtaken over de levensloop. Immers, door te investeren in het behouden en vernieuwen van het individuele menselijke kapitaal, kan het arbeidzame leven worden verlengd. Waar nu mensen door veroudering van hun kennis en vakbekwaamheid vervroegd uittreden, is dan een profijtelijke voortzetting weer mogelijk. Ook zou de levensfase waarin men vanwege de zorg voor kinderen, het investeren in een loopbaan en eventueel hoge financiële verplichtingen in verband met een eigen huis, wat gemakkelijker gemaakt kunnen worden. Het is deze samenhang die door Bovenberg steeds wordt benadrukt: "reconciliation of work and family goes 
beyond child-care facilities and parental leave during the family phase but involves the entire life course" (Bovenberg 2005: 18).

Niet alleen door verlenging van het arbeidzame leven, maar ook door een andere organisatie van de sociale zekerheid zou deze verlichting tijdens het 'spitsuur' van het leven kunnen worden verkregen. De gedachte hierbij is dat driekwart van alle collectieve heffingen uiteindelijk leiden tot uitkeringen aan dezelfde personen van wie deze heffingen afkomstig zijn. Slechts een vierde komt ten goede aan anderen, in het kader van inkomensherverdeling (Bovenberg 2005: noot op 15). Door de introductie van individuele spaarrekeningen kunnen individuen zelf hun prioriteiten stellen met betrekking tot het doel waarvoor en het moment waarop men geld van deze rekening wil gebruiken. Onvoorzienbare risico's worden op minimaal niveau verzekerd, omdat men individueel door benutting van zijn/haar spaarrekening dit minimale uitkeringsniveau kan verhogen.

\subsubsection{SLOTOPMERKINGEN}

Zoals hierboven is besproken, wordt de wens om de ww te beoordelen op mogelijkheden tot verbetering, ingegeven door het oneigenlijke gebruik ervan door moral hazard. Moral hazard kan tot uitdrukking komen in een grotere instroom, een kleinere uitstroomkans naar betaald werk en een hogere gebruiksfrequentie.

De regulering van de instroom dient in samenhang te worden gezien met het ontslagrecht, omdat beide (het toestaan van ontslag en het toekennen van een uitkering) twee kanten van één (overheids)medaille zijn. Een grotere instroom dan nodig kan worden voorkomen door het vergroten van de werkzekerheid. Het aanpassingsvermogen is dan zodanig ontwikkeld dat de tijd tussen de dreiging van ontslag en de ingang ervan meer dan nu het geval is, kan worden benut voor het vinden van een nieuwe baan. Bevordering van de interne flexibiliteit is hierbij behulpzaam.

Met betrekking tot de verblijfsduur blijken twee factoren essentieel om een onnodig lange verblijfsduur te beperken, namelijk een voortdurende aandacht of begeleiding om het zoekgedrag op een actief niveau te houden, en het aanreiken van instrumenten in de vorm van reïntegratietrajecten om een eventuele afstand tot de arbeidsmarkt te verkleinen. Ofschoon sanctiebeleid onmisbaar is voor het tegengaan van evidente gevallen van misbruik, kan het algemene oogmerk, het voorkomen dat mensen de uitkeringssituatie als een normale situatie ervaren, beter worden bereikt door ondersteunende begeleiding.

Voor wat betreft de reïntegratietrajecten zal het veelzijdige aanbod van private bedrijven nodig zijn om aan de verscheidenheid aan wensen te kunnen voldoen. Resultaatfinanciering, zo werd in par. 6.3 besproken, is nodig om de effectiviteit te kunnen waarborgen. Keuzevrijheid, zoals vormgegeven door de IRO, kan ook een bijdrage leveren aan de effectiviteit, zolang de oriëntatie op terugkeer naar de arbeidsmarkt vooropstaat. 


\subsection{CAO's}

\subsubsection{INLEIDING}

Cao's vormen de concretisering van vele aspecten van arbeidsrelaties. Opvattingen en wensen met betrekking tot de flexibilisering en dynamisering van de arbeidsmarkt krijgen praktische betekenis wanneer deze in cao-afspraken neerslaan. Wettelijke regelgeving kan niet los worden gezien van afspraken in cao's. Veel sociale regelgeving heeft het karakter van minimumbepalingen of -voorzieningen. Worden deze waarborgen verlaagd, zoals in de afgelopen jaren vanwege de budgettaire sanering en de liberalisering van de arbeidsmarkt, vaak het geval was, dan kan toch de oude situatie als uitkomst van het cao-overleg worden gehandhaafd. Het 'opvullen' van het zogenaamde WAO-gat vormt hiervan het bekendste voorbeeld. Omgekeerd kunnen moderniseringen in cao's worden bevorderd door wetgeving. Veranderingen in cao's die de overgang vergemakkelijken naar een situatie waarin niet baanzekerheid maar werkzekerheid wordt nagestreefd, zijn dan ook van evident belang. Naast deze overgang van baanzekerheid naar werkzekerheid kunnen employability-afspraken een grotere reikwijdte krijgen als het gaat om het streven naar een hogere participatie. De bekende problemen: het laagste segment van de arbeidsmarkt, het combineren van arbeid en zorg, en de inschakeling van oudere werknemers, komen dan in beeld (Wilthagen 2005: 83).

Verbetering van employability wordt niet zelden gelijkgesteld met scholing, of het actualiseren van de vakkennis die werknemers hebben, en het vergroten van de kennis van de ontwikkelingen op de onderdelen van de arbeidsmarkt waarvan zij deel uitmaken. De werkgever kan door het stimuleren, (mede) financieren en qua tijdsbeslag mogelijk maken van dergelijke activiteiten, de employability vergroten. Naast de verantwoordelijkheid van de werkgever is vooral ook die van de werknemer cruciaal. Ervaringen met individuele reïntegratiecontracten (Sol \& Westerveld) laten immers zien dat de eigen inbreng van de werkloze een belangrijke factor is voor het welslagen van reïntegratietrajecten. Het gunnen van de regie over een loopbaan aan de betrokkene zelf zien we ook terug in cao's waar sprake is van het instrument van persoonlijke ontwikkelingsplannen.

Binnen het ruime terrein van de 'flexicurity-strategieën' hebben cao-bepalingen als het gaat om de overgang naar een andere baan, een minder heldere betekenis. Cao-bepalingen betreffen de oude werkgever, niet de nieuwe, en hierdoor is sprake van een inherente spanning. Alleen in onvoorziene omstandigheden immers, zoals een teleurstellende ontwikkeling in het functioneren van een werknemer of overbodig geworden arbeidsplaatsen, is vertrek van werknemers in het belang van de werkgever, en juist dit onvoorziene karakter maakt het onwaarschijnlijk dat cao-bepalingen die dit vertrek vergemakkelijken, soepel en vanzelfsprekend van de grond komen. Voorzorgsmaatregelen hebben bovendien een generiek karakter, zodat deze ook ten goede komen aan werknemers voor wie ontslag niet van toepassing zal blijken te zijn. Wanneer deze werknemers door 
het bevorderen van hun employability ertoe gebracht worden van baan te veranderen, zijn de maatregelen zelfs contrair aan het belang van degene die ze als onderdeel van een cao ontwikkelt. Ook om deze reden lijkt de primaire regie voor employability bij de werknemer te moeten liggen.

In ruimere zin kunnen vele arrangementen bijdragen aan het bevorderen van werkzekerheid. Bezien vanuit de arbeidsmarkt wordt flexibiliteit (anders dan die van de werknemer) ook vergroot door de 'numerieke flexibiliteit', die wordt bereikt door overwerk, flexibele week- of jaarroosters, en oproepcontracten (Tijdens en Van der Meer 2000: 19).

\subsubsection{ONTWIKKELINGEN IN NEDERLANDSE CAO'S}

In de jaren zestig en zeventig vormde de loonontwikkeling het hoofdbestanddeel van het cao-overleg. Later zijn ook andere onderwerpen deel gaan uitmaken van het arbeidsvoorwaardenoverleg. Zaken als loopbaanbegeleiding, arbeidsomstandigheden en het combineren van arbeid en zorgtaken deden hun intrede (Verhulp 2005a: \$5.1). In 2001 publiceerde de Stichting van de Arbeid de nota Werk maken van employability-beleid. De stichting wilde hiermee een nieuw evenwicht bevorderen van "vergroting van de flexibiliteit van arbeid in samenhang met vergroting van de werkzekerheid van werknemers". De nota onderscheidt hierbij de volgende vier typen van 'nieuwe(re) typen van cao-bepalingen':

- Arbeidsmarktgerichte voorzieningen, zoals het opzetten van een vacaturebank en een periodieke arbeidsmonitoring in de bedrijfstak;

- Diagnosestellende voorzieningen, zoals een employability-scan, een systeem van Eerder Verworven Competenties, en het opstellen van een scholing- en ontwikkelingsplan;

- Financiële maatregelen zoals het toekennen van een (persoonlijk) opleidingsplan, en

- Loopbaanbevordering en mobiliteitsvergroting, zoals loopbaangesprekken en de inrichting van een mobiliteitscentrum.

Voor wat betreft de rolverdeling staat in de 'Conclusies en Aanbevelingen' dat "de werkgever en de werknemer in dezen een eigen en een gezamenlijke verantwoordelijkheid hebben".

Employability heeft in de opzet van de Stichting van de Arbeid een duidelijk karakter van voorzorg: er wordt aanbevolen om te investeren in 'baanzekerheid' gedurende de vervulling van een lopende functie. ${ }^{4}$ Het blijkt dat in vrijwel alle cao's één of meer van de hierboven genoemde typen van cao-bepalingen voorkomen. Zo kennen vrijwel alle cao's bepalingen met betrekking tot scholing (szW 2006b: \$8). Het merendeel hiervan heeft evenwel betrekking op functiegerichte scholing. Het is de vraag of dit bijdraagt aan employability. Als de functie nogal specifiek is en de scholing de band met de functie versterkt, kan de employability mogelijk zelfs afnemen. Algemene vormen van scholing komen slechts bescheiden voor en raken minder dan 2 procent van de werknemers. Ofschoon employability-afspraken ook voorkomen, hebben de meeste betrekking op werkzoeken- 
den en daarmee komen we terecht bij de nazorg. Afgezien van voorlichting komen andere employability-afspraken in cao's in 2005 slechts sporadisch voor. Bezien over een periode van 2000-2005 wordt geconstateerd dat "het percentage cao's met afspraken over employability (...) vrijwel constant is gebleven". Met betrekking tot persoonlijke opleidingsplannen en functioneringsgesprekken is er wel sprake van een stijging.

Voor wat betreft de participatie van laagopgeleiden zijn de cao-bepalingen met betrekking tot de laagste loonschalen van belang. Om voor laagopgeleiden de stap naar een baan mogelijk te kunnen maken is het nodig dat er banen zijn met zodanig lage lonen dat ook weinig productieve werkzoekenden interessant zijn voor een werkgever. Vanwege de armoedeval bevinden de reguliere loonschalen zich boven het niveau van het minimumloon. Dit om het verschil met een bijstandsuitkering interessant genoeg te laten zijn. Om voor jongeren de toegang tot de arbeidsmarkt mogelijk te maken zijn aanloopschalen en doelgroepschalen geïntroduceerd. Als men via deze lager betaalde schalen binnenkomt, kan men door het opdoen van werkervaring doorgroeien naar de reguliere schalen. Ruim een kwart van de cao's kent dergelijke schalen. Doelgroepenschalen starten exact op het niveau van het wettelijke minimumloon, de aanloopschalen 2 à 3 procent daarboven, terwijl de reguliere schalen 8 procent hoger uitkomen. Van belang is ook dat in de afgelopen jaren de laagste schaalbedragen zijn gedaald, waarmee de arbeidsmarktkansen voor laagopgeleiden dus verbeteren. Deze beweging is voor alle sectoren zichtbaar. Ook de spreiding is gereduceerd; waar in 1999 de laagste schaalbedragen varieerden tussen 103 procent en 116 procent van het minimumloon, is dat in 2005 een bandbreedte van 102 procent tot 108 procent (SZW 2006b: 7-15). Met betrekking tot levensloopregelingen zijn de ontwikkelingen minder aansprekend. Weliswaar is voor ongeveer driekwart van de werknemers een of meer afspraken hierover opgenomen in cao's, maar deze zijn voor het merendeel niet uitgewerkt. Het gaat om met name verlofregelingen die van toepassing zijn op verlof tijdens de loopbaan of voorafgaand aan het pensioen (sZW 2006b: 27). Ook in het ruimere kader van het flexibiliseringsstreven zijn de nieuwe initiatieven niet noemenswaardig. Cao's voorzien niet in bovenwettelijke arrangementen om arbeid en gezinstaken te combineren (Schreuder 2004: 25).

Voor wat betreft de participatie van ouderen is enige urgentie geboden. De participatie van mannen van 60 tot en met 64 jaar is in 2005 nog geen 34 procent tegenover ruim 90 procent voor de leeftijdscategorie 50-54 jaar. Voor vrouwen gaat het om 18 procent tegenover ruim 6o procent (Ekamper 2006). De urgentie tot verruiming van de participatie is gelegen in de drastische beperkingen die in de uittrederoutes WAO/WIA, WW en vut zijn aangebracht. Voor nieuwe categorieën zal met name een beroep moeten worden gedaan op eigen besparingen om eerder dan op 65-jarige leeftijd te kunnen ophouden met werken. Overigens zijn er ten aanzien van de participatie wel vorderingen gemaakt: tien jaren terug bedroeg het percentage niet 34 maar 20 procent. Stijging van dit percentage verdient ook prioriteit in het licht van de thans in discussie zijnde maatregel om de pensioengerechtigde leeftijd te verhogen. Uitgaande van de huidige participatiegraad van 64-jarigen, te 
weten 8 procent, zal dit nauwelijks soelaas bieden; eerst dient de participatie van de categorie jonger dan 65 jaar te worden verhoogd (СРВ 2006: 126).

In het advies Van alle leeftijden heeft de SER geadviseerd een tweesporenbeleid te volgen: enerzijds een verbeterde incentivestructuur, anderzijds een leeftijdsbewust personeelsbeleid (SER 2005b: 9). Tot het tweede spoor behoren de zogenaamde 'ontziemaatregelen' waarmee ouderen worden ontzien als het gaat om overwerk, ploegendiensten en nachtdiensten (SER 2005b: 55). De mogelijkheid van demotie wordt ook genoemd, maar dan op initiatief van de werknemer die een minder zware of belastende functie op een lager niveau zou willen. Kijken we naar de cao's, dan blijkt dat 30 procent ervan leeftijdgerelateerde employabilityafspraken bevat (szW 2006b: 48). Veel van deze afspraken betreffen extra verlofen vakantiedagen, alsook flexibelere werkroosters (Tros 2004: 11). Ook voor deze afspraken geldt dat hun aantal in de loop van de periode 2000-2005 vrijwel constant is gebleven (SzW 2006b: 49).

Met betrekking tot de nazorg, het bevorderen van employability van degenen die ontslagen worden, is het beeld niet rooskleuriger. De essentie van de employability-gedachte in de nazorg komt erop neer dat de geboden ondersteuning niet financieel van aard is, maar activerend. Dit in lijn met de gedachte "werk boven inkomen" en met de verandering van een passief naar een activerend beleid. Vooralsnog blijkt het accent op financiële tegemoetkomingen te worden gehandhaafd. Overigens kan ook de financiële steun activerend worden ingezet.

Wanneer het in een cao overeengekomen uitkeringsbedrag oploopt bij het vinden van een nieuwe baan, is er een duidelijke incentive tot reïntegratie. Voor de periode 2001-2005 als geheel is de conclusie dat "het beeld ten aanzien van externe herplaatsing minder activerend is" en dat "sociale partners nog steeds duidelijk prioriteit leggen bij inkomenszekerheid”, terwijl ook de financiële incentives niet verbeterd zijn (Tros et al. 2005: 537, 536, 534). Scholingsafspraken zijn in hoofdzaak functiegebonden en bieden niet de ruimte voor een niet-functiegebonden oriëntatie (Tijdens en Van Klaveren 2004: 63). Wel worden afspraken gemaakt om de interne herplaatsingen beter te benutten.

\subsubsection{ONTWIKKELINGEN IN EUROPA}

Ondanks het feit dat er in Nederland weinig toename is geweest van cao-afspraken die de employability bevorderen, is ons land toch toonaangevend op dit terrein, dit overigens samen met Denemarken (Wilthagen 2004: 92; Bonoli \& Sarfati 2002: 480). Dit komt niet doordat de institutionele setting in andere landen sterk zou afwijken van die in Nederland. Ruim 70 procent van alle werknemers in de EU valt onder een cao, waarbij het in de meeste gevallen gaat om bedrijfstak-cao's (Visser 2001). De belangrijkste beweging die in de EU in cao's wordt gemaakt is die van decentralisatie. Dit vanwege de "reorganisatie van het werk en de vervanging van hiërarchische organisaties met eenvoudige taken door plattere structuren rond complexer zaken die meer besluitvorming op lagere niveaus in de organisatie vereisen" (Visser 2001: 3). Hoewel in vele lidstaten de 
vergrijzingsproblematiek pregnanter en de participatiegraad lager is dan in ons land, ontbreekt het er aan initiatieven om met combinaties van flexibiliteit en zekerheid ouderen te activeren (Tros 2005: 17). Het is dus niet goed mogelijk om bij het analyseren en adviseren over 'flexicurity'-initiatieven aansluiting te vinden bij datgene wat er in het buitenland gebeurt.

Met betrekking tot de participatie van ouderen verdient de Deense situatie bespreking. Tegenover een werkgelegenheidsgraad voor de categorie van 55 jaar en ouder van iets meer dan 40 procent voor de vijftien EU-landen, kent Denemarken een cijfer van 60 procent. Afgezien van een aanpassing van de regelingen voor vervroegde uittreding in 1999 heeft de overheid geen bijzonder beleid gevoerd, omdat dit een taak voor het bedrijfsleven is. Noch speelt, anders dan in Nederland, dit onderwerp er prominent bij de cao-onderhandelingen (Tros 2004: 8).

\subsubsection{DE RELATIE TUSSEN FLEXICURITY EN WETGEVING}

Zoals in de inleidende paragraaf is opgemerkt, worden veel arbeidsvoorwaardelijke aspecten geregeld, ingekaderd of bevorderd door wettelijke maatregelen. Dit kan ook raken aan het onderwerp van flexibiliteit en zekerheid. Zo wijst Tros c.s. op de optie om "employability-kosten in mindering te brengen op de ontslagvergoeding": "in sociale plannen waarin veel investeringen in werk-naar-werk trajecten zijn geregeld, zou dan kunnen worden volstaan met lagere ontslagvergoedingen" (Tros et al. 2005: 536). Ook het voorstel van de FNV om werkgevers zelf de werkloosheidsuitkering te laten betalen, heeft een verschuiving van inkomens- naar werkzekerheid op het oog. De werkgever kan immers de premielast ontgaan of verminderen door "het voorkomen van ontslag. Bijvoorbeeld door scholing van de werknemer en hun naar nieuw werk te begeleiden" (Ton Heerts, Nos journaal, 11-7-2006). Ook hier wordt de relatie met het ontslag gelegd. Bij deze opties kunnen enkele kanttekeningen worden gemaakt. Het is de bedoeling van de FNV dat werkgevers en werknemers samen verantwoordelijk worden gemaakt. Als deze verantwoordelijkheid ertoe strekt dat er bereidheid is tot het aanbieden en ontvangen van scholing is er veel gewonnen, maar de vraag is of dit in termen van werkzekerheid een afdoende invulling is. Voor externe mobiliteit is het ook nodig om "medewerkers mentaal onafhankelijk te maken en zelf eigenaar te laten zijn van de eigen loopbaan", zoals het oogmerk is van enkele recente employability-afspraken (SzW 2006b: 49). Het zal evenwel niet eenvoudig zijn om deze afspraken en deze oogmerken zo concreet te doen zijn dat ze een reële afruil met de ontslagbepalingen kunnen vormen, zodat het de vraag is of hiermee volstaan kan worden.

Ten tweede is er de in paragraaf 6.2.2 gesignaleerde spanning binnen een generiek employability - beleid in de sfeer van de voorzorg. Employability als onderdeel van nazorg laat zich moeiteloos formuleren, omdat de individuele casus hierbij het vertrekpunt vormt. Generieke voorzorg daarentegen omvat iedereen, ook degenen die de werkgever liever niet mobiel ziet worden. Een regierol van de werknemer lijkt daarom onmisbaar. 
Ten derde is er de vertaalslag van employability-inspanningen naar werkgelegenheid. Wanneer deze inspanningen pas als volwaardig worden beschouwd als deze daadwerkelijk tot een baan hebben geleid, wordt de inzet een werkgarantie. Zoals gezegd zou zo'n garantie de flexibiliteit op de arbeidsmarkt schaden. Maar als het geen werkgarantie is, wat is het dan wel? Het antwoord op deze vraag is met de nodige creativiteit en overleg zeker wel tot een goed einde te brengen, maar dan moeten er ook daadwerkelijk stappen in die richting worden gezet. Ook volgens Tros c.s. is het ontbreken van een antwoord op deze vraag de reden dat men vooralsnog opteert voor inkomenszekerheid: "als er weinig garanties op nieuw werk worden gegeven, is de neiging voor de vakbeweging groot de compensatie voor ontslag te zoeken in inkomen" (Tros et al. 2005: 536).

\subsubsection{SLOTOPMERKINGEN}

Van degenen die instromen in de ww doet 14 procent dit door tussenkomst van het CWI of de kantonrechter vanwege het verkrijgen van de ontslagvergunning. Deze zelfde groep evenwel vormt meer dan de helft ( 54 procent) van de groep van 'langverblijvers', personen die gedurende meerdere jaren in de Ww vertoeven (Van Ewijk \& Engelen 2001: 10). Het tekort aan employability lijkt zich derhalve met name bij deze groep voor te doen, en niet bij de 86 procent instroom van overige categorieën. Hun kans om langverblijver te worden is bijna 8 keer kleiner (54/14 gedeeld door 46/86). Beleid gericht op het versterken van de employability van een werknemer zal dus vooral effectief zijn als het degenen bereikt die via een ontslagprocedure werkloos worden. De aanwezigheid van een ontslagprocedure, anders dan pro forma, duidt op de afwezigheid van instemming met het beëindigen van de arbeidsrelatie. Wie zich concentreert op de voorwaarden waaronder het contract wordt ontbonden, zal minder geneigd zijn te anticiperen op een vervolg van de loopbaan na het ontslag. Naast deze mogelijke attitudekwestie kan ook feitelijke geschiktheid voor een volgende baan een probleem zijn. Afwezigheid van instemming duidt er ook op dat men een voorkeur heeft om de oude baan te continueren. Deze oriëntatie impliceert dat men zich niet vanzelf door scholing, netwerken of het verwerven van nieuwe competenties voorbereidt op een andere baan.

Meer aandacht voor het risico een baan te verliezen en de noodzaak een andere baan te verwerven kan worden bevorderd door werknemers met deze eventualiteit te confronteren. Zo geeft de Stichting van de Arbeid de volgende cao-bepaling inzake een persoonlijk ontwikkelingsplan als voorbeeld: "De werkgever bespreekt ten minste eenmaal per jaar met elke werknemer de ontwikkeling in zijn functioneren en inzetbaarheid in het licht van persoonlijke omstandigheden en ambities, ontwikkelingen op het vakgebied van de werknemer, in de onderneming en op de arbeidsmarkt. Afspraken die in dit gesprek worden gemaakt, worden schriftelijk vastgelegd, waarbij de afspraken gericht op behoud en ontwikkeling van de inzetbaarheid het karakter van een op de werknemer afgestemd ontwikkelingsplan dragen. (Cao's AKzo Nobel)" (Stichting van de Arbeid 2001: 11). 
Op dergelijke wijze zou het aanpassingsvermogen van werknemers kunnen worden vergroot en hun kwetsbaarheid bij onvoorziene omstandigheden kunnen worden verminderd. Het is bemoedigend dat juist in dit opzicht cao's wel een groter bereik vertonen. Inmiddels heeft 50\% van de cao's afspraken hierover opgenomen. Ongetwijfeld zal de uitwerking en naleving van zo'n relatief nieuw item mogelijkheden tot verbeteringen vertonen. Ook het zeer bescheiden percentage van afspraken over een persoonlijk opleidingsbudget, in zekere zin het complement van het persoonlijke ontwikkelingsplan, geeft aan dat de effectieve implementatie van deze bepaling nog bescheiden is.

Een volgend onderwerp betreft de participatie van ouderen. Ondanks de urgentie van het probleem blijken de cao-afspraken ter bevordering van de participatie van ouderen geen stijging te vertonen. $\mathrm{Nu}$ is het zo dat degenen die op hogere leeftijd uittreden, inkomen ontlenen aan WAO, WW en vut. De toegang tot de WAO is strenger geworden, de maximale verblijfsduur in de wW is verkort van 5 naar 3 jaar (terwijl de vervolguitkering al eerder was verdwenen) en de VUT wordt in toenemende mate actuarieel neutraal, hetgeen in de praktijk de benutting van deze route zeer sterk zal doen verminderen. Ondanks de dominantie van werkende mannen in de oudere leeftijdsklassen, wordt er voor ongeveer de helft in deeltijd gewerkt (Tros 2004: 10). Tegelijkertijd zijn er geen signalen die erop duiden dat demotie een grote vlucht neemt. Kennelijk is de voorkeur om minder dagen te werken, veel sterker dan de voorkeur om lichter werk te gaan doen.

\subsection{CONCLUDERENDE OPMERKINGEN}

In het voorafgaande is een vijftal instituties besproken. In het WRR-rapport $D e$ verzorgingsstaat herwogen wordt behandeld hoe Nederland zich door voortdurende aanpassingen zou kunnen moderniseren in respons op actuele ontwikkelingen. Dat gebeurt met behoud van de karakteristieken die kenmerkend zijn voor onze verzorgingsstaat. In plaats van een drastische keuze voor een andersoortig beleid gaat het veeleer om klein en groot onderhoud. Grosso modo geldt dat ook voor de arbeidsmarktinstituties, al zijn de onderlinge verschillen niet gering. Met betrekking tot het ontslagrecht zijn diverse wijzigingen doorgevoerd (versoepelingen met tijdelijke contracten; beperking verwijtbaarheidstoets; vervanging lifobeginsel door afspiegeling) zonder dat de hoofdstructuur van het ontslagrecht is veranderd. Problemen die zich in de sfeer van het ontslagrecht voordoen lijken zich te concentreren in een relatief kleine groep van werknemers die naar de mening van de werkgever niet naar behoren functioneren.

Met betrekking tot het minimumloon zien we dat, met behoud van de functie van het WML in het loongebouw, door ontkoppeling (van het WML van de lonen) belangrijke werkgelegenheidseffecten voor laagopgeleiden zijn geëffectueerd, terwijl door wijzigingen in het bruto-nettotraject de koopkracht geen nadeel van deze ontkoppelingen heeft ondervonden. Het loslaten van deze lijn, waardoor het minimumloon onder het uitkeringsniveau zou komen te liggen, zal de groep van uitkeringsontvangers doen groeien. Het arbeidsmarktbeleid vertoont een 
duidelijke trend van een toenemend activerend karakter, maar er is ook een komen en gaan van maatregelen, initiatieven en experimenten. Dit tast de geloofwaardigheid aan en ook ontbreekt daardoor de tijd om te investeren in de effectiviteit van het beleid. De concentratie van het huidige arbeidsmarktbeleid op reïntegratie-inspanningen, in combinatie met de work-first-benadering van gemeenten, is aantoonbaar succesvol en kan ook worden aanbevolen op basis van de internationale literatuur. Het zou de voorkeur verdienen als incidentele tegenvallers of gebeurtenissen niet langer tot beleidswijzigingen leiden, maar aanleiding geven tot verbeteringen, zodat deze vorm van activering verder aan kwaliteit wint. De $W W$ heeft ook grote veranderingen ondergaan, maar de wenselijkheid van verdere aanpassingen tekent zich af vanwege de mogelijke aansluiting bij de gedachtevorming van individuele spaarvarianten en vanwege de wenselijkheid om de tijd die men in de ww doorbrengt meer dienstig te laten zijn aan het bevorderen van employability. Ten slotte geven ook de cao's een ontwikkeling te zien waarbij nieuwe thema's vrij soepel worden geagendeerd. Het uitwerken en concretiseren van deze voornemens, om de hiermee beoogde doelstellingen te effectueren, is hierbij een logische vervolgstap.

Het intact laten van beleid wanneer geen evidente problemen in het geding zijn, is ook raadzaam, omdat de hier besproken instituties deel uitmaken van de normen en omgangsvormen die er op de arbeidsmarkt en in de arbeidsrelaties bestaan. Zoals werkzekerheid de flexibiliteit ten goede kan komen, kan zekerheid in de basispatronen van onze instituties een goede basis verschaffen voor het introduceren van veranderingen die geboden zijn. De hier besproken thema's vertonen een duidelijke samenhang. Ontslagbescherming en de ww bieden beide vormen van inkomenszekerheid. In het employability-kader wordt geprobeerd beide dienstbaar te maken aan het streven naar werkzekerheid. Het streven naar werkzekerheid is er altijd al geweest in de vorm van het reïntegratiebeleid. Met employability als gemeenschappelijk kenmerk is er dus alle reden om aanpassingen in deze regelingen naar meer werkzekerheid, in samenhang te bezien. 


\section{NOTEN}

I Snelheid is overigens geen kenmerk van het Deense stelsel, omdat werklozen eerst de tijd gegund wordt zelf een baan te zoeken. Pas na het verstrijken van deze periode volgt de verplichting tot medewerking aan reïntegratie (zie Geerdsen 2006: 740).

2 Een simpele berekening maakt deze uitkomst ook intuïtief plausibel. Als 60 procent van de bevolking nooit een beroep doet op de ww, zal het gemiddelde beroep van de 40 procent wel gebruikers, uitgaande van een gemiddelde wWbezettingsgraad van 4 procent, 1o procent bedragen, ofwel 4,5 jaar op lifetimebasis. Verdelen we deze groep van 40 procent in vier subgroepen van elk 1o procent, en gaan we er hypothetisch van uit dat de eerste groep 1 jaar in de WW doorbrengt, de tweede 2 jaar en de derde 5 jaren, dan is de verblijfsduur van de vierde groep, met het hoogste gebruik, gecumuleerd 1o jaren.

3 Er is bovendien het risico van een pervers effect wanneer degenen die op lifetimebasis geen tekort zouden vertonen, maar op enig moment wel een tekort hebben, gedemotiveerd raken om een baan te zoeken op grond van een inschatting dat het saldo toch niet meer positief zal worden.

$4 \quad$ Van nazorg is sprake als ontslag actueel is. 


\section{HOOFDLIJNEN VAN EEN TOEKOMSTBESTENDIGE ARBEIDSMARKTPOLITIEK}

\subsection{INVESTEREN IN WERKZEKERHEID}

Dit rapport gaat over investeren in werkzekerheid. Investeren is daarbij een centraal begrip, dat verwijst naar een dubbele opdracht. Daarbij gaat het allereerst om het investeren in mensen, om het investeren in werknemers. Die zullen in de toekomst steeds minder kunnen vertrouwen op een baan voor het leven. Die baanzekerheid zal daarom moeten worden vervangen door werkzekerheid. Het vertrouwen in werkzekerheid kan alleen ontstaan indien er bij voortduring wordt geïnvesteerd in werknemers op een arbeidsplek, in werklozen op zoek naar een baan en in mensen die nu nog buiten de arbeidsmarkt vallen. Door investeringen in hun vaardigheden worden ze inzetbaar. Door die investeringen blijven ze inzetbaar in een steeds meer veranderlijke arbeidsomgeving. Maar investeren in mensen zelf is niet voldoende. Een adequate toerusting van werknemers vraagt ook om investeringen die zijn gericht op de verandering van onze huidige arbeidsmarktinstituties. Ook dat vraagt om investeringen en een op de toekomst gericht groot onderhoud van die instituties. De bestaande arbeidsmarktinstituties zijn ontwikkeld in een tijd waarin de Nederlandse economie nog vooral nationaal, en de Nederlandse arbeidsorganisaties nog vooral industrieel waren georiënteerd. Een toekomstbestendige arbeidsmarktpolitiek zal rekening moeten houden met een economie die omwille van internationalisering over een groot aanpassingsvermogen moet beschikken.

Doelstellingen zullen moeten worden geformuleerd voor een werkelijkheid waarin arbeidsorganisaties er heel anders uit gaan zien. Een toekomstbestendige arbeidsmarktpolitiek zal rekening moeten houden met een samenleving die ook in cultureel opzicht sterk veranderd is, en waarin zich heel nieuwe vormen van onzekerheid zullen manifesteren. Van werknemers en van grote en kleine werkgevers zal worden verwacht dat zij zich adequaat aan telkens nieuwe situaties kunnen aanpassen. Daarvoor moeten nieuwe combinaties van flexibiliteit en zekerheid worden ontwikkeld. Het gaat daarbij om nieuwe ambities, die moeten worden ondersteund door vertrouwenwekkende instituties. Instituties die dus niet langer primair zijn gericht op compensatie van het verlies van 'de baan voor het leven', maar instituties die bijdragen aan werkzekerheid voor iedereen in een economie die snel moet kunnen veranderen. Investeren in flexibiliteit en werkzekerheid is dus niet alleen een opdracht voor de huidige arbeidsmarkt: het is vooral ook een opdracht voor de toekomst. Al in de komende decennia zal de arbeidsmarkt immers te maken krijgen met een lage of zelfs negatieve groei van het arbeidsaanbod. Daardoor kunnen situaties van kwantitatieve krapte ontstaan die in vele sectoren van onze economie voor grote problemen kunnen zorgen. Als de lonen als gevolg van krapte op de arbeidsmarkt in delen van de marktsector snel stijgen, heeft dat bijvoorbeeld 
negatieve consequenties voor de publieke sector, die als gevolg van afspraken in de sfeer van het begrotingsbeleid en de daar vooralsnog beperktere mogelijkheden voor productiviteitsverbetering, al snel zal worden geconfronteerd met scenario's van verschraling en versobering.

Om deze en elders in het rapport uitvoerig behandelde overwegingen is het nodig en urgent om te werken aan nieuwe richtingen voor een toekomstbestendige arbeidsmarktpolitiek. Het onderzoek dat voor dit rapport is verricht maakt duidelijk dat toekomstige problemen in het functioneren van de arbeidsmarkt niet alleen een kwantitatief karakter hebben. Er is ook sprake van een meer kwalitatief probleem. In een wereld waarin nieuwe patronen van globalisering, veranderingen in de manier waarop arbeidsorganisaties worden ingericht als gevolg van het steeds snellere tempo van product- en procesvernieuwing draagt arbeidsmarktpolitiek in belangrijke mate bij aan de mogelijkheden om onze welvaart vast te houden. De doorwerking van demografische factoren zoals de vergrijzing en de ontgroening, de betekenis van maatschappelijke ontwikkelingen zoals de combinatie van arbeid en zorg, en de verandering van een passieve naar een activerende sociale zekerheid, vertalen zich in steeds hogere eisen aan het aanpassingsvermogen van onze economie.

In de hoofdstukken 3, 4 en 5 is de feitelijke mobiliteit van de huidige Nederlandse arbeidsmarkt uitvoerig belicht. Daarin komt naar voren dat de mobiliteit eenzijdig aan het begin van de loopbaan geconcentreerd is en dat bepaalde groepen op de arbeidsmarkt noodgedwongen meer mobiliteit vertonen dan gemiddeld. Door de mobiliteit te optimaliseren kan het maatschappelijke en economische draagvlak worden versterkt. Met het oog op de toekomst moeten de mogelijkheden voor interne en externe mobiliteit van werknemers versterkt worden.

Dit hoofdstuk wijst nieuwe richtingen voor een toekomstbestendige arbeidsmarktpolitiek, die investeert in werkzekerheid. De manier waarop dat gebeurt, spoort met de veranderingen in de opvattingen ten aanzien van het sociaal beleid, waarbij er een nieuw evenwicht tussen rechten en plichten wordt nagestreefd. Het centrale thema van dit rapport is het investeren in de capabilities van mensen en in werkzekerheid. Werknemers hebben de regie in de richting en inhoud van deze investeringen, maar krijgen daarvoor door werkgevers en samenleving middelen aangereikt. Deze investeringen liggen aan de basis van werkzekerheid. Door deze investeringen zijn mensen voor de hele duur van hun loopbaan beter inzetbaar. Het aanreiken van middelen om in capabilities te investeren heeft een tweeledig effect. Het vergemakkelijkt de overgangen op de arbeidsmarkt voor de werkenden, en het bevordert de participatie van degenen die geen baan hebben of deze dreigen te verliezen.

Mobiliteit, verandering van de ene baan naar de andere, kent risico's. Is of voelt men zich wel geschikt voor die andere baan? Het risico van werkloosheid raakt een fundamentele waarde, niet alleen door de financiële consequenties, maar 
nog meer door het verlies aan eigenwaarde en sociale contacten (Layard 2005: 62-68). Bescherming tegen verlies van werk verdient een hogere prioriteit dan bescherming tegen verlies aan inkomen alleen. De arbeidsmarkt is veel meer dan een markt waar vraag en aanbod samenkomen. De uitkomsten van deze markt zijn immers in hoge mate bepalend voor de sociale kansen die mensen worden geboden.

Bij inactiviteit en werkloosheid gaat het volgens de richting die dit rapport wijst niet langer primair om schadeloosstelling voor verlies van werk, maar om het aanreiken van de middelen om de schade van dat verlies zelf te kunnen herstellen. Eenzelfde idee ligt ook aan de basis van de omzetting van een passieve naar een activerende sociale zekerheid die al eerder is ingezet.

Het vergroten van capabilities vormt de essentie van het beleid gericht op werkzekerheid. Het verschaffen van de juiste capabilities behoort in Sens visie tot de kern van het tegenwoordige overheidsoptreden (Sen 1999; Layard 2005: 113). Overheden moeten mensen in staat stellen zich die capabilities te verschaffen, en moeten dus niet passief en afhankelijk makend zijn, maar activerend en zelfstandigheid bevorderend. Systemen die mensen afhankelijk houden, of tot afhankelijkheid verlokken, zijn hoogstens incidenteel sociaal, maar niet structureel. Het verwerven en onderhouden van capabilities behoort tot de verantwoordelijkheid van individuen: de overheid en de sociale partners moeten de voorwaarden scheppen om mensen in de gelegenheid te stellen deze verantwoordelijkheid te nemen. Betere onderlinge afstemming van instituties en versterking van hun functionaliteit ten behoeve van werkzekerheid, zullen hun effectiviteit vergroten.

In dit hoofdstuk zal de hier besproken richting verder worden uitgewerkt. Het gaat daarbij over de uitwerking van de richting waarin volgens de raad een toekomstgerichte arbeidsmarktpolitiek zich de komende jaren zou moeten ontwikkelen. Het gaat de raad daarbij vooral om de richting, aan de hand waarvan de concrete inrichting van het beleid de komende jaren kan worden getoetst en vormgegeven. De raad zal terughoudend zijn bij het formuleren van elementen die de daadwerkelijke en concrete inrichting van dit beleid betreffen. Daarbij is het nodig om aandacht te geven aan een veelheid van vaak nog onvermoede uitvoeringsaspecten die de reikwijdte en doelstelling van dit rapport te boven gaan. Wel is duidelijk dat de hieronder beschreven richting een breuk betekent met de nog veelal traditionele wijze waarop bijvoorbeeld het huidige, gedecentraliseerde arbeidsvoorwaardenbeleid wordt vormgegeven. Het verder ontwikkelen van de hier beschreven richting vergt niet alleen het verder investeren in een inhoudelijke uitwerking ervan, maar vraagt ook om het vormgeven van een leerweg waarlangs deze vernieuwingen tot een succes kunnen worden gemaakt. In paragraaf 7.6 zal daarom afzonderlijk op dit belangrijke onderwerp van wat men een vorm van sociale innovatie zou kunnen noemen, worden ingegaan. 


\subsection{HET BEVORDEREN VAN WERKZEKERHEID}

\subsubsection{GENERIEKE UITGANGSPUNTEN}

Bij het ontwerpen van een beleid gericht op werkzekerheid wordt een aantal generieke uitgangspunten in acht genomen.

- Werkzekerheid veronderstelt preventie: wanneer pas aan werkzekerheid wordt gewerkt als ontslag dreigt, is men eigenlijk te laat. Huidige voorbeelden van WW-preventie worden veelal gekenmerkt door een (te) late start (Evers et al. 2004: 80).

- Werkzekerheid vereist het verwerven en op peil houden van capabilities: alleen dan kunnen personen voortdurend in aanmerking blijven komen voor nieuwe banen.

- Werkzekerheid vergt betrokkenheid van alle partijen: werknemers, werkgevers, cao-partijen en overheid hebben elk hun rol bij werkzekerheid.

- Werkzekerheid vereist maatwerk en differentiatie: de wijze waarop werkzekerheid wordt vormgegeven moet voor de verschillende arbeidsmarktsegmenten en -groepen adequaat zijn. Dit vraagt om decentrale invullingen met oog voor individuele wensen.

- Werkzekerheid vereist daarom wederzijds verplichtende zelfregulering: een brede betrokkenheid van alle partijen in combinatie met het bieden van maatwerk vergt een vormgeving die recht doet aan de arbeidsmarktgroepen en bedrijfsspecifieke situaties.

Tezamen genomen geven deze uitgangspunten een duidelijk perspectief in welke richting de bestaande arbeidsmarktarrangementen de komende jaren moeten worden herijkt. Toepassing van deze uitgangspunten vraagt op de korte termijn in ieder geval tot een betere afstemming van de bestaande instituties en legt daarmee een belangrijke basis voor een verdere toekomstbestendige invulling van werkzekerheid.

Bij dreigend verlies van werkgelegenheid geldt dat hoe eerder mobiliteit mogelijk is, hoe minder de schade als gevolg van werkloosheid zal zijn. Door de voorwaarden en ondersteuning zo in te richten dat alle vormen van mobiliteit zoveel mogelijk de kenmerken hebben van vrijwilligheid, ontstaat er een situatie die voor alle partijen aantrekkelijker is. In plaats van curatieve compensatie wordt hier gekozen voor preventieve toerusting. Mogelijkheden om capabilities te verwerven moeten in een heel vroeg stadium worden aangeboden (Heckman 2006).

\subsubsection{INHOUDELIJKE HOOFDLIJNEN}

In deze paragraaf bespreken we de uitgangspunten bij het vormgeven van werkzekerheid. Het basisprincipe daarbij is dat zo vroeg mogelijk wordt geïnvesteerd in de capabilities van de werknemer, waardoor hij of zij gewapend is tegen de risico's van de flexibele arbeidsmarkt van de toekomst. Deze aanpak heeft niet alleen consequenties voor de mobiliteit van baan naar baan, maar ook voor die van func- 
tie naar functie en voor de transities van buiten naar binnen de arbeidsmarkt. Deze consequenties zullen voor elk van deze gevallen worden uitgewerkt nadat het basisprincipe op hoofdlijnen is vormgegeven.

Werkzekerheid kan worden opgebouwd uit de volgende inhoudelijke oriëntaties:

1 investeren in een leven lang leren en loopbaanregie;

2 inkomensbescherming ten dienste van werkzekerheid;

3 bundeling van de reïntegratie-inspanningen;

4 een antwoord bieden voor de 'nieuwe risico's' .

Deze vier oogmerken worden nu door de bestaande arbeidsmarktinstituties in sterk wisselende mate bediend. Dat komt doordat deze arbeidsmarktinstituties, die in de volgende subparagrafen nader worden besproken, zich grotendeels los van elkaar hebben ontwikkeld. De gegroeide versnippering is niet doelmatig, vooral omdat het ontbreekt aan een gemeenschappelijke richting. De raad stelt voor om een inhoudelijke samenhang ook qua timing tussen arrangementen aan te brengen, en ze qua timing op elkaar af te stemmen. In het poortwachtersmodel van de WAO/WIA is een succesvolle invulling gegeven aan zo'n afstemming. Elk van deze vier oriëntaties komt terug in de volgende subparagrafen.

Nieuwe ambities vragen om nieuwe allianties. Om werkzekerheid daadwerkelijk te kunnen realiseren is een ambitieuze aanpak nodig. Het bundelen, afstemmen en versterken van scholingsinvesteringen, loopbaanplanning, activerende inkomensbescherming, rë̈ntegratie-inspanningen en sociale zekerheid is hiervoor een eerste vereiste.

\subsubsection{INVESTEREN IN LEVENSLANG LEREN EN LOOPBAANREGIE}

In hoofdstuk 6 is gebleken dat, hoewel vrijwel alle cao's afspraken kennen over vormen van investeren in 'werkzekerheid', deze in de praktijk toch vaak beperkt blijven tot bestaande functies. Scholing, die algemeen als een hoofdbestanddeel ter invulling van deze afspraken wordt beschouwd, ligt daarom vaak in het verlengde van deze functies. Algemene scholing, die wel bijdraagt aan werkzekerheid in ruime zin, komt slechts sporadisch voor.

Een scholingsinspanning als invulling van inzetbaarheid (employability), dient niet louter ingegeven te worden door de actuele behoefte van het bedrijf, maar dient ook steeds meer geënt te worden op een loopbaanperspectief (binnen en buiten het huidige bedrijf). De ontwikkeling van dat perspectief is primair een zaak van de werknemer. De helft van de cao's kent afspraken, of beginselafspraken, over loopbaanbevordering en mobiliteit. De uitwerking van deze afspraken behoort evenwel nog niet tot de staande praktijk.

Scholing, een leven lang leren en loopbaanplanning zijn de essentiële investeringselementen voor werkzekerheid tijdens de loopbaan. Door deze in samenhang tot ontwikkeling te brengen, kunnen ze een belangrijke rol spelen bij de 
transities van functie naar functie en van baan naar baan. Dat betekent dat de invulling van de afspraken over scholing een minder functiegebonden karakter moet krijgen, en moet aansluiten op de conclusies die uit het loopbaanperspectief voortvloeien. Ook kunnen de leerwensen andere activiteiten betreffen dan scholing alleen, zoals het verwerven van sociale vaardigheden of het meedoen aan functieroulatie. Het loopbaanperspectief kan aan de orde komen bij het persoonlijke ontwikkelingsplan, bij het bedrijfsontwikkelingsplan, bij loopbaanadvisering of bij mobiliteitsbemiddeling.

Afspraken over de investering in scholing en over het loopbaanperspectief (bijvoorbeeld die in cao's) moeten vergroting van werkzekerheid als doel krijgen.

\subsubsection{INKOMENSBESCHERMING TEN DIENSTE VAN WERKZEKERHEID}

De ww biedt een vorm van inkomensbescherming voor periodes van werkloosheid tussen twee banen in. Bij onvrijwillig ontslag zijn er echter nog andere vormen van inkomensbescherming, te weten de loondoorbetaling gedurende de opzegtermijn en de ontslagvergoeding. Deze drie vormen van inkomensbescherming zijn niet op elkaar afgestemd. De hoogte van de ene vorm is niet van invloed op de andere twee. Ook zijn ze qua timing en qua oogmerk onvoldoende gericht op het creëren van werkzekerheid.

Bij de overgang van de ene baan naar de andere baan is inkomensbescherming niet alleen noodzakelijk als tijdelijke bescherming tegen een forse inkomensdaling. De drie hier genoemde vormen van inkomensbescherming zouden alle drie ook een functie kunnen hebben als een financiële ondersteuning bij het zoeken naar een nieuwe baan. Maar die functie is niet altijd even evident en ook is er geen afstemming tussen deze inkomensinstrumenten. Zo is het niet ondenkbaar dat een hoge ontslagvergoeding vooral uitstel of afstel kan betekenen van het zoeken naar een volgende baan. Herijking ten dienste van werkzekerheid ligt in de rede.

De loondoorbetaling gedurende de opzegtermijn en de ontslagvergoeding moeten, met het oog op werkzekerheid, opgaan in één regeling ter financiering van de loondoorbetaling in een afgebakende zoekperiode.

\subsubsection{BUNDELING VAN REÏNTEGRATIE-INSPANNINGEN}

Wanneer de werkgever tot ontslag wil overgaan, dient hij de mogelijkheden onderzocht te hebben om de betreffende werknemer voor zijn bedrijf te behouden. Ook wanneer dit enige aanpassingen zou vergen van de werkzaamheden van de competenties van de werknemer, is de werkgever daartoe gehouden. Wanneer desondanks ontslag onvermijdelijk is, zal gezocht moeten worden naar mogelijkheden voor een baan elders. Outplacement-trajecten vormen doorgaans een belangrijk bestanddeel van sociale plannen. Wanneer outplacement door de werkgever en de werknemer geen succes heeft gehad vóór de datum van ontslag, dan zal het CWI de werkzoekende beoordelen op de kansen op herintreding. Zijn 
deze groot, dan kan het CWI besluiten tot lichte vormen van reïntegratie-inspanningen. Zijn deze kansen niet groot, of hebben de inspanningen onder regie van het CWI niet het beoogde effect, dan zal het UWv het vervolg ter hand nemen, wat als regel een regulier reïntegratietraject impliceert.

Op dit moment staan de reïntegratie-inspanningen van de werkgever (in samenwerking met de werknemer die op zoek is naar een nieuwe baan) grotendeels los van de reïntegratie-inspanningen die in een vervolgtraject tijdens een werkloosheidsperiode door publieke instellingen zoals het CWI en het UWV worden geleverd. Een bundeling van deze beide investeringen in reïntegratie ligt om doelmatigheidsredenen voor de hand. De wijze van aanbesteding kan profiteren van een bundeling van expertise. Zo adviseert SEO dat het de voorkeur verdient dat het UWv bedrijven laat bieden op het plaatsingspercentage, uitgaande van een gefixeerde prijs (SEO 2006: 49).

Wanneer reïntegratie in één keer succesvol is, bespaart dit tijd en geld. Daarenboven kan een bundeling van beide reïntegratie-investeringen mogelijk tot gevolg hebben dat werkloosheid daarmee kan worden voorkomen. Wanneer een periode van werkloosheid kan worden vermeden is dat altijd winst voor de betrokken werknemer en voor de samenleving.

Het bundelen van de reïntegratie-inspanningen door werkgever, CWI en UWV draagt bij aan de snelheid en de effectiviteit ervan.

\subsubsection{EEN ANTWOORD BIEDEN VOOR DE 'NIEUWE RISICO'S'}

In hoofdstuk 1 is opgemerkt dat de hier voorgestelde nieuwe richtingen voor een toekomstgericht arbeidsmarktbeleid mede zijn gebaseerd op nieuwe inzichten over het sociale beleid, die aansluiten bij de huidige maatschappelijke omstandigheden. Welke groepen worden geholpen, en onder welke condities, en wanneer, zijn vragen die voor verschillende arbeidsmarktgroepen en onder verschillende omstandigheden, anders moeten kunnen worden beantwoord. De specifieke problemen zijn daarbij waarschijnlijk steeds belangrijker dan het behoren tot een bepaalde groep per se. Bij het ontwerpen van het socialezekerheidsstelsel in ons land heeft inkomensbescherming vooropgestaan. Intussen is de activerende rol van de socialezekerheidsregelingen goed in de steigers gezet. Daarmee is reïntegratie nog steeds primair een aangelegenheid van degenen die hun baan al zijn kwijtgeraakt. Daarnaast zijn er ook instrumenten tot ontwikkeling gebracht om mensen die door persoonlijke omstandigheden hun baan dreigen te verliezen, te behouden voor de arbeidsmarkt. Daardoor is het bijvoorbeeld gemakkelijker geworden om arbeid en zorg en arbeid en scholing te combineren. Het beslag van deze instrumenten op het totale budget is echter bescheiden, en dat geldt ook voor de zogenaamde 'nieuwe risico's' (combinatie arbeid en zorg, arbeid en scholing en de inschakeling van kwetsbare groepen op de arbeidsmarkt; zie ook WRR 2006:158 en subparagraaf 7.6.2). 
Bij de vormgeving van werkzekerheid moet rekening worden gehouden met werknemers die arbeid en zorg of arbeid en onderwijs moeten of willen combineren, met werknemers die om persoonlijke omstandigheden hun baan dreigen te verliezen en met groepen die buiten de arbeidsmarkt staan.

\subsection{WERKZEKERHEID EN DE TRANSITIES VAN FUNCTIE NAAR FUNCTIE}

In de hierboven geformuleerde aanbevelingen geeft de raad enkele richtingen aan voor de manier waarop op een toekomstbestendige wijze vormgegeven kan worden aan werkzekerheid. Het betreft daar vooral hoofdrichtingen, geïnspireerd door de analyses die wijzen op de noodzaak en de wenselijkheid van aanpassingen en veranderingen die nodig zijn om het doel van werkzekerheid dichterbij te brengen. In het vervolg van dit hoofdstuk worden op basis van deze hoofdrichtingen de mogelijke contouren van werkzekerheid verder uitgewerkt voor elk van de drie centrale transities van dit rapport: de transities van functie naar functie, van baan naar baan, en van buiten naar binnen.

\section{7·3.1 INTERNE MOBILITEIT}

Bij een overgang van functie naar functie binnen een bedrijf is er geen sprake van werkloosheid. In zoverre is de werkzekerheid niet in directe zin aan de orde. Maar op indirecte wijze is de relatie evident. Ten eerste kan door interne mobiliteit het risico van werkloosheid worden verminderd. Wie op vele uiteenlopende plaatsen inzetbaar is, is veel minder kwetsbaar wanneer bepaalde bedrijfsactiviteiten worden verminderd of afgestoten. Ten tweede heeft interne mobiliteit een belangrijke functie voor externe mobiliteit. Wie heeft geleerd om gemakkelijk om te gaan met nieuwe werkzaamheden, contacten en taken binnen het bedrijf zal het ook minder bezwaarlijk vinden dergelijke veranderingen tegen te komen buiten het bedrijf. Het investeren in soepele overgangen van functie naar functie vormt dus een krachtige impuls voor het vergroten van de werkzekerheid.

Ofschoon diverse initiatieven zijn ontwikkeld, schort er nog veel aan de inzetbaarheid die nodig is om gemakkelijk van functie naar functie te kunnen veranderen. Bedrijfsopleidingen liggen vaak in het verlengde van de huidige functie. Veertig procent van de werkgevers in het OSA-arbeidsvraagpanel acht zijn huidige personeel niet voldoende toegerust voor toekomstige ontwikkelingen binnen het eigen bedrijf (Brouwer et al. 2001).

Het versterken van de mogelijkheden van interne mobiliteit is primair een zaak van werkgevers en werknemers. Dat geldt in beginsel ook voor de kosten van zo'n beleid. Wanneer door het vergemakkelijken van interne mobiliteit een vergroting van de werkzekerheid kan worden verkregen, zal het beroep op de werkloosheidsregelingen afnemen. De hierdoor vrijvallende middelen bieden compensatie voor de kosten van het ontwikkelen van interne mobiliteit. 


\subsubsection{LOOPBAANPERSPECTIEF}

Het is zaak om de interne mobiliteit op gang te brengen, los van de context van reorganisaties en ontslagen. Preventie vergt inspanningen lang voordat ontslagen zich aandienen. Hier is een belangrijke regierol weggelegd voor de werknemer. Een werknemer kan zelf veel bijdragen aan werkzekerheid. Werknemers houden zich op de hoogte van de maatschappelijke ontwikkelingen rondom hun beroep. Zij onderhouden hun vakmanschap, en spiegelen hun functioneren aan dat van hun collega's. Zij hebben opvattingen over andere beroepen die verwant zijn aan hun vak, aan hun hobby's, of beroepen die regionaal eruit springen. Met deze oriëntaties kunnen werknemers zich een beeld vormen van de loopbaanmogelijkheden. Het ontwikkelen van dat beeld kan een vast onderdeel worden gemaakt van al bestaande kaders. Dit kan gebeuren via loopbaanperspectieven, mobiliteitsafspraken, jobroulatieschema's, detacheringen of persoonlijke ontwikkelingsplannen, maar ook in het kader van bedrijfsontwikkelingsplannen of loopbaanadvisering. Het agenderen van het ontwikkelen van een loopbaanperspectief is een taak van de werkgever. Het kan onderdeel vormen van de reguliere functioneringsgesprekken, waarvoor het initiatief ook bij de werkgever ligt. Het ontwikkelen van de inhoud van het perspectief behoort tot de verantwoordelijkheid van de werknemer. Alleen de werknemer kan de keuzes maken voor zijn eigen loopbaan.

Ofschoon inzetbaarheid of employability-afspraken thans in meer dan de helft van de cao's voorkomen, is het gewenst dat de ontwikkeling van individuele loopbaanperspectieven algemeen ingang gaat vinden, als basis voor de feitelijke loopbaanontwikkeling en als basis voor het vergroten van de inzetbaarheid van alle werknemers. Bij het verkennen van de loopbaanmogelijkheden is de ervaring die men heeft opgedaan in de huidige baan richtinggevend. Sterke en zwakke punten op uiteenlopende terreinen kunnen ertoe leiden dat nagedacht wordt over een loopbaanvervolg waarbij de sterke punten meer worden benut en de zwakke punten minder. Ook kan zo'n analyse ertoe leiden dat men investeert in leerwegen om die zwakke punten te elimineren.

Functioneringsaspecten kunnen een rijke schakering vertonen. Het gaat om veel meer dan het kennisniveau dat men in technische zin bezit. Zoals in hoofdstuk 6 is gebleken, tellen sociale vaardigheden, motivatie, loyaliteit en discipline even zwaar, zo niet zwaarder. Het leerpotentieel ten aanzien van deze aspecten moet dan ook volle aandacht krijgen.

Cao-afspraken over individuele loopbaanperspectieven met het oog op het vergroten van de inzetbaarheid van werknemers moeten algemene ingang vinden.

\subsubsection{TIJD EN MIDDELEN}

Modaliteiten van loopbaanperspectieven, eenmaal opgesteld, hebben als logisch vervolg dat tijd, middelen en instrumenten worden gevonden om de aanbevelin- 
gen ervan uit te werken. Een persoonlijk opleidingsbudget zou daarvan deel kunnen uitmaken. Op dit moment zijn er betrekkelijk weinig cao-afspraken die hierin voorzien. Ook al is vooral bij kleine bedrijven het gebruik van de omvangrijke reserves in de O\&O-fondsen toegenomen (Baris en Verhulp 2007), toch bestaat de indruk dat deze fondsen op dit moment nog niet ten volle hiervoor worden benut. Het vergroten van sociale vaardigheden en het verwerven van noodzakelijke attitudes zal andere inspanningen vergen dan louter op cognitieve kennis gerichte opleidingen. Trainingen, begeleiding en monitoren kunnen de gewenste veranderingsprocessen bevorderen. Veranderingen in de werkplekken kunnen ook ertoe bijdragen dat men profijtelijke werkomgevingen leert te onderscheiden van minder passende.

Het ligt in de rede dat de bereidheid van de werknemer om te investeren in zijn loopbaan toeneemt met de daadwerkelijke mogelijkheden om hier wat aan te doen. Persoonlijke leerrechten zijn in dit verband voorgesteld (Baris en Verhulp 2007; SER 2006). Duidelijk moge zijn dat deze in het verlengde moeten liggen van loopbaanopties die primair door de werknemer zelf zijn overdacht. Cursussen en bijscholing die niet passen in het loopbaanperspectief genieten geen voorrang. Investeringen in employability moeten immers hun waarde bewijzen op het moment dat een transitie naar een andere baan of functie actueel is. Dan moet de werknemer in de positie verkeren om eerder overwogen loopbaanopties te kunnen benutten. Alleen de werknemer kan dit commitment voor zichzelf aangaan.

Een verdere stap in deze gedachtegang vormt het stimuleren van interne mobiliteit, ook wanneer de noodzaak van een reorganisatie niet aan de orde is. Veel bedrijven kennen processen waarbij werknemers rouleren. Dit zal gemakkelijker zijn naarmate de personeelsomvang groter is. Voor een tweemansbedrijf waarin er een de baas is, valt er weinig te rouleren. Ook is mobiliteit moeilijker naarmate functies minder gemeenschappelijke kenmerken hebben. Niet elke ICT-medewerker kan de functie van personeelsadviseur zonder mankeren overnemen, en omgekeerd. Voor die situaties, die eerder regel dan uitzondering zijn, zal het nodige moeten gebeuren. Benutting van branchegewijze of regionale initiatieven kan hier een oplossing bieden. Detachering vormt hiervoor een modaliteit. Ondanks praktische beperkingen is interne roulatie toch een belangrijke toetssteen als het gaat om de vraag hoe serieus men het investeren in employability moet nemen. Als een werknemer meer dan een decennium op dezelfde plaats zit, is de voorbereiding om te blijven participeren op een steeds veranderende arbeidsmarkt bepaald onvoldoende als die positie slechts een beperkt scala van functievereisten kent. Tegenover het toekennen van de regieverantwoordelijkheid aan de werknemer moet dan ook de verplichting staan van de werkgever om de mogelijkheden te bieden om deze verantwoordelijkheid in te vullen.

Investeringen in het loopbaanperspectief vergen tijd en middelen. Bronnen als o\&O-fondsen dienen hiervoor via persoonlijke opleidingsbudgetten en persoonlijke leerrechten productief gemaakt te worden. (Aanvullende) initiatieven op het niveau van de branche of regio zijn daarvoor zeer gewenst. 


\subsection{WERKZEKERHEID EN DE TRANSITIE VAN BAAN NAAR BAAN}

\subsubsection{SAMENVOEGING VAN INKOMENSBESCHERMING EN EMPLOYABILITY}

\section{Inkomensbescherming}

Zoals opgemerkt zal de ervaring die men opdoet bij functiewisseling de stap naar baanwisseling vergemakkelijken. De meeste baanwisselingen worden vrijwillig ondernomen. Bij vrijwillig ontslag is vaak sprake van een positieverbetering. Gedwongen ontslag kent overwegend nadelen: voor de werkgever (vanwege de onkosten en vergoedingen), voor de werknemer (vanwege de inkomensachteruitgang en de mentale schade ondervonden door werkloosheid) en voor de overheid (vanwege de uitkeringen en de reïntegratie-inspanningen).

Het aanbrengen van werkzekerheid moet ertoe leiden dat onvrijwillige baanwisselingen zoveel als mogelijk de kenmerken hebben van vrijwilligheid. In de tijd die gelegen is tussen de dreiging of aankondiging van ontslag en de effectuering daarvan, zou men kans moeten zien om op eigen sterkte een andere baan te verwerven. Employability is daartoe het middel, geïnitieerd door loopbaanwensen die men al eerder heeft geformuleerd. Wanneer ontslag in het verschiet ligt, komen diverse vormen van inkomensbescherming en reïntegratie aan de orde, waarvan de bundeling, zoals hierboven is besproken, kan bijdragen aan efficiency en het voorkomen van de schade die door werkloosheid wordt berokkend.

Integratie van de drie vormen van inkomensbescherming betekent het in samenhang bezien van de loondoorbetaling tijdens de opzegtermijn, de ontslagvergoeding en ook de werkloosheidsuitkering. Het integreren van de reïntegratieinspanningen betekent dat de trajecten van de werkgever, CWI en UWV worden gebundeld. Het samenbrengen van deze activiteiten ter bevordering van de werkzekerheid betekent dat de inkomensbescherming dienstbaar wordt gemaakt aan het vinden van een nieuwe baan. Hoe zou dit samenvoegen er in hoofdlijnen uit kunnen zien?

Als een werknemer die ontslag is aangezegd, erin slaagt een nieuwe baan te vinden tegen min of meer dezelfde arbeidsvoorwaarden, vervalt vanuit inkomensbescherming de reden voor het toekennen van een ontslagvergoeding. Als de loondoorbetaling tijdens de opzegtermijn niet primair wordt benut voor het vinden van een nieuwe baan, heeft deze uitbetaling vooral de functie van inkomensbescherming. Zonder gecombineerd te worden met reïntegratie-inspanningen hebben beide uitbetalingen het karakter van compensatie voor (anders optredende) werkloosheid, een functie die ook wordt vervuld door de ww.

Gedurende de opzegtermijn en zeker na goedkeuring van het ontslag is de werkgever niet langer gehouden reïntegratie-inspanningen te verrichten, tenzij in sociale plannen anders is overeengekomen. Bij ontslag vanwege persoonlijke omstandigheden liggen reïntegratiepogingen door de werkgever niet meer in de rede. De werkgever heeft immers moeten aantonen dat hij deze al (via met name interne overplaatsing) eerder, maar vruchteloos, heeft ondernomen. Beide 
vormen van inkomensbescherming zijn vanuit het oogpunt van werkzekerheid gemiste kansen.

Door de reïntegratie-inspanningen te bundelen kan sneller en effectiever worden gewerkt. De opeenvolging van reïntegratie-inspanningen schaadt de effectiviteit en geloofwaardigheid. Na een poging volgt er immers weer een andere. Deze halfslachtigheid kan worden vermeden door meteen voluit in te zetten op reïntegratie.

De aanvang hiervan kan samenvallen met het tijdstip waarop de werkgever tot de conclusie is gekomen dat hij tot ontslag wil overgaan. Deze conclusie moet natuurlijk aan betrokkene schriftelijk worden meegedeeld. Daarop kan dan een opzegtermijn volgen, gedurende welke loondoorbetaling van toepassing is, en die het karakter heeft van een zoektijd. In deze periode immers krijgt reïntegratie maximale voorrang. De duur van deze opzeg- en zoekperiode zal variëren met het dienstverband. De werkgever is immers meer reïntegratie-inspanningen verschuldigd jegens zijn werknemer naarmate deze langer in dienst is, omdat de werkgever al die tijd heeft kunnen investeren in de employability van de werknemer. Als die investering een goede is geweest zal deze zich uitbetalen in een verkorting van de opzeg- en zoekperiode, die met het vinden van een baan wordt beëindigd. De zoekperiode neemt zo de plaats in van de ontslagvergoeding, waarin de duurafhankelijkheid van het arbeidsverleden tot uitdrukking komt. De reïntegratie-inspanningen tijdens de zoekperiode vergen maatwerk. Wenselijke verschillen naar branche, regio en individu moeten kunnen worden gehonoreerd. De invulling van de reïntegratie-inspanningen is onderwerp van het cao-overleg. In paragraaf 7.4.3 wordt dit uitgewerkt. Gezien de essentie van deze inspanningen voor het verkrijgen van werkzekerheid, zou deze vorm van ontslag afhankelijk gemaakt moeten worden van het bereiken van cao-afspraken over deze invulling.

Als is voldaan aan drie formele elementen (tijdige aankondiging, inachtneming van de zoektermijn en adequate invulling van de activiteiten tijdens de zoekperiode), is tussenkomst van CWI of kantonrechter bij ontslagverlening niet meer nodig.

Gelet op de veelheid van inhoudelijke en procesmatige veranderingen die de hier geschetste aanpak impliceren, wordt in paragraaf 7.6 ingegaan op de mogelijkheid van een ingroeimodel in een overgangsfase.

\section{Employability}

Om de reïntegratie zo effectief mogelijk te maken is het nodig dat ook de expertise en instrumenten van het UWV worden benut. Inschakeling van private reïntegratiebedrijven blijft hierbij, zoals thans ook het geval is, een reële optie. Het is nu al mogelijk de inschakeling van het Uwv bij de reïntegratie te verwerven vóór het moment van het ingaan van het ontslag. Dit zou in deze gedachtegang een gangbare praktijk worden. De aard en reikwijdte van de reïntegratie-inspanningen, alsmede de optie dat de zoekperiode al dan niet benut kan worden voor het 
voltooien van de bestaande baan, zijn onderwerpen waarover sociale partners nadere afspraken kunnen overeenkomen. Het ligt in de rede dat deze inspanningen in het verlengde liggen van de activiteiten die in het kader van het loopbaanperspectief en de daaruit voortvloeiende scholingsinspanningen zijn ontplooid. Op de verankering van de hierover te maken afspraken wordt in de volgende paragraaf nader ingegaan.

De voordelen van zo'n gedachtegang betreffen primair de snelheid. Het is een feit dat reïntegratie succesvoller verloopt naarmate er meer snelheid wordt betracht. Als men eenmaal werkloos is, leiden het verlies van het dagelijkse contact met de werkvloer en het verlies van arbeidsritme tot een achterstandspositie, terwijl het stigma van de werkloosheid de werkzoekende bij sollicitaties parten kan spelen. Bovendien concentreert de werkzoekende dan alle energie op het vinden van een nieuwe baan, terwijl thans die energie niet zelden wordt gestoken in het zo lang mogelijk aanvechten van het ontslag. Deze drastische heroriëntatie is vergelijkbaar met die van de nieuwe arbeidsongeschiktheidsregeling, waarbij "het activeren van beschikbare arbeidsgeschiktheid voorrang krijgt op het verzekeren van arbeidsongeschiktheid" (SER 2002: 33). In lijn hiermee wordt hier bepleit om voorrang te geven aan het benutten van de geschiktheid voor een nieuwe baan, in plaats van aan het compenseren voor de ongeschiktheid van de oude baan. Het bundelen van alle middelen en expertise komt de geloofwaardigheid en de effectiviteit van de reïntegratiepogingen ten goede. Via de aansluiting bij het loopbaanperspectief en de daaruit volgende activiteiten is de inbreng van de werkzoekende verzekerd. Zoals blijkt uit de ervaringen met IRO's (Individuele Reïntegratieovereenkomsten) is dit een cruciale factor voor het succesvolle verloop van reïntegratietrajecten. De besparingen van de omzetting van de ontslagvergoeding in de zoekperiode en de besparingen door het lagere beroep op de werkloosheidsregeling, kunnen worden aangewend voor de financiering van de employability-inspanningen in deze fase.

Bundeling van de beschikbare middelen en expertise op het terrein van reïntegratie verdient aanbeveling omdat deze tijdwinst en grotere slagkracht kan opleveren.

\subsubsection{ORIËNTEREN, LEREN EN REÏNTEGREREN}

Hierboven is beschreven dat de ontwikkeling van een loopbaanperspectief de basis zou moeten vormen voor de leer-en opleidingsactiviteiten tijdens het werk. Ook is aangegeven dat reïntegratie bij dreiging van baanverlies in het verlengde moet liggen van deze activiteiten. Een eerste voorwaarde is dan dat deze activiteiten een individueel karakter moeten hebben. Voorts is van belang dat de opleidingen bijdragen aan de employability en niet primair gericht zijn op de bestaande baan. Essentieel is dat de leeractiviteiten de actieradius van de werknemer vergroten. Daarvoor moet men zich oriënteren op de buitenwereld, het vakgebied, de (regionale) arbeidsmarkt en de interesses die men heeft. Het signaleren van lacunes en het ontwikkelen en concretiseren van leerwensen is daarom van belang. De Stichting van de Arbeid heeft hiertoe de optie van een employability-scan geop- 
perd (SER 2OO2: 53). Voorts hebben sociale partners, onderwijsveld en gemeenten recentelijk in een manifest bepleit om iedereen de mogelijkheid te geven om tijdens zijn loopbaan een EVC-procedure (Erkenning van Eerder Verworven Competenties) te volgen. Deze kan dan worden benut "voor bredere loopbaanmogelijkheden binnen én buiten de eigen sector en inzicht in de daarvoor benodigde scholingsinspanningen" (HBO-raad en RWI 2006: 8). In België is met dit doel voor ogen het recht op een loopbaanoriëntatie ontwikkeld, met inbegrip van ondersteuning door een externe loopbaanadviseur (EIRR 2006: 28-29).

Ook moet er ruimte zijn voor het versterken van sociale vaardigheden en werkattitudes. In hoofdstuk 6 bleek immers dat dergelijke aspecten in toenemende mate bepalend zijn voor het succesvol vervullen van een baan. Voor het midden- en kleinbedrijf is voorts gebleken dat trainingsbegeleiding sterk bepalend is voor het succes van opleidingen (De Kok 2003: 160).

Wanneer reïntegratieondersteuning aan de orde is, moet er ook ruimte zijn voor de overgang naar een baan als zelfstandige ondernemer. Zeker voor personen met een ruim arbeidsverleden kan het aantrekkelijk zijn te opteren voor een bestaan als zelfstandige. Continuering van de werkzaamheden is mogelijk door middel van het overnemen van een bestaand bedrijf. Неt MKв heeft aandacht gevraagd voor het feit dat het overheidsbeleid te veel gericht is op bedrijfsovernames binnen de familie. Het vergemakkelijken van de toegang tot de bestaande kredietfaciliteit voor bedrijfsoverdrachten voor juist de wat minder grote kredieten wordt als een belangrijke wens ervaren. Andere knelpunten bij bedrijfsoverdrachten kunnen worden weggenomen door een adequate ondersteuning van of bemiddeling bij de aan- en verkoop van een bedrijf (ING Bank en MKB 2005).

Een belangrijk element betreft het verplichtende karakter. Een zo gewichtige kwestie als werkzekerheid vergt heldere afspraken. Die afspraken bieden de werknemer zowel rechten als plichten. Enerzijds moet men aanspraak kunnen maken op tijd en middelen voor het ontwikkelen van een loopbaanperspectief, het volgen van opleidingen en cursussen, en het benutten van reïntegratieondersteuning, anderzijds is men ook gehouden hierin te investeren. Er is dus ook een leerplicht (Krause 2006). Door het aanbrengen van deze nieuwe fundamenten onder scholing en opleidingen kan er een einde komen aan het feit dat er "geen duidelijk beleid zit achter de besteding van opleidingsbudgetten” (zie par. 4.3.5). Met de toenemende vraag zullen ook de o\&O-fondsen meer worden aangesproken.

Ontwikkeling van het loopbaanperspectief en de hieruit voortvloeiende opleidingen is ook noodzakelijk omdat zij een effectieve basis voor reïntegratie-inspanningen opleveren.

\subsubsection{VERANKERING VAN AFSPRAKEN OVER EMPLOYABILITY}

In deze paragraaf wordt aandacht besteed aan de vraag hoe de employabilityafspraken zo stevig kunnen zijn dat men er staat op kan maken. Keerzijde van de medaille dat employability-inspanningen op individueel niveau te regelen zijn, is 
dat ze ook op individueel niveau zonder negatieve invloed op de arbeidsrelatie opvraagbaar moeten zijn. Daarom moeten deze aanspraken contractueel of wettelijk worden vastgelegd. Wanneer in eerste instantie afspraken in cao's worden neergelegd, wordt recht gedaan aan de behoefte aan differentiatie die zich in de praktijk voordoet. Daarbij is de financiële omvang van de overeengekomen arrangementen niet zonder belang. Het zou wenselijk zijn om uit te gaan van een financieel beslag dat voor alle bedrijven in zekere mate vergelijkbaar is. Niet alleen bevordert dit een min of meer gelijke aanpak in het bedrijfsleven, hetgeen dienstig is met het oog op de concurrentieverhoudingen. Ook maakt het een financiële verevening eenvoudiger indien men vanwege de overloopeffecten tot een gemeenschappelijke financiering wil overgaan, zoals aanvankelijk het oogmerk was van de O\&O-fondsen. Met name voor het Mкв kan dit van belang zijn. De nadere uitwerking van de oriëntatie-, scholings- en reïntegratie-inspanningen in cao's biedt de ruimte voor differentiatie en ook voor individueel maatwerk. Circa 85 procent van de werknemers in Nederland heeft te maken met afspraken die in meer dan rooo cao's (bedrijfstak- en ondernemingscao's) worden overeengekomen. Afgezien van de verschillen tussen deze cao's zijn er vele mogelijkheden voor differentiatie binnen cao's. Cao's kunnen kaderbepalingen opnemen waarbij de uitwerking en detaillering wordt overgelaten aan gedecentraliseerde niveaus, waaronder ondernemingsraden. Maar cao's kunnen ook keuzemogelijkheden bieden (cao à la carte) tot op individueel niveau.

Speciale aandacht verdient in dit verband het midden- en kleinbedrijf. Omdat 70 procent van de werkgelegenheidsmutaties zich in het MKB voordoen, heeft deze sector bij uitstek met deze problematiek van doen (Bangma et al. 2005: 32). Van de MKB-bedrijven kent 80 procent deels betaalde cursussen of opleidingen (Valk 2006: 4). De organisatie van scholing, die voor een kleine organisatie een grote belasting kan vormen, wordt vaak ter hand genomen door brancheorganisaties en/of regionale samenwerkingsverbanden. Het MKB kent 135 brancheorganisaties die zich steeds meer op de arbeidsmarktvraagstukken van hun leden richten. Gelet op de schaalomvang zullen jobroulatie, functiewisseling en reïntegratie vaak in samenwerking met andere bedrijven moeten plaatsvinden. Ook hiervoor kunnen brancheorganisaties goede diensten bewijzen en zij doen dat ook, zoals blijkt uit de initiatieven die zijn ontwikkeld voor de reïntegratie van gedeeltelijk arbeidsgeschikten.

Ook met het oog op de financiering ligt het uitwerken van deze richting in caoafspraken voor de hand. De gedeeltelijke omzetting van passieve vormen van inkomensbescherming door de werkgever naar actieve vormen kan het beste worden vormgegeven op cao-niveau. Het te verwachten geringere beroep op de WW kan als premieverlichting worden meegenomen. Maar ook anderszins kan een grotere bijdrage van de overheid (door middel van ondersteuning door het UWV en/of ruimere fiscale facilitering van opleidingen, dan wel door middel van een groter aandeel bij het verminderen van de zogenaamde nieuwe risico's, zie par. 7.6 ) tot uitdrukking komen. Met de primaire financiering door werkgevers en overheid ligt ook enige medefinanciering door werknemers in de rede. Dit is 
immers in lijn met de verantwoordelijkheid die zij hebben als regiehouder van hun loopbaan.

Wanneer er in betekenende mate cao's tot stand zijn gekomen met dergelijke uitwerkingen, kan de wetgever de hoofdlijnen daarvan overnemen. De belangrijkste gemeenschappelijke categorieën die uit de cao-afspraken blijken, kunnen het raamwerk vormen van een geschikte publiekrechtelijke regeling. Een kaderwet is een van de mogelijke regelingen. Een dergelijke algemene regeling is vooral van belang voor werkgevers met werknemers die niet onder een cao vallen, maar kan natuurlijk ook worden benut voor die onderdelen van het bedrijfsleven die, hoewel onder een cao vallend, nog niet tot afspraken zijn gekomen.

Een verdere ontwikkeling en verankering van de aanspraken op ondersteuning van employability-inspanningen zou primair op het niveau van cao-afspraken moeten worden geregeld; de voornaamste afspraken kunnen vervolgens ook in een meer algemeen werkende kaderwet worden neergelegd.

\subsection{WERKZEKERHEID EN DE TRANSITIES VAN BUITEN NAAR BINNEN}

Het vertrouwen dat men zonodig of desgewenst een nieuwe baan kan vinden, is niet in alle lagen van de bevolking even groot. Probleemgroepen zijn oudere werknemers en werknemers aan de onderkant, waaronder veel allochtonen met een lage opleiding. Werknemers die hun betaalde arbeid combineren met zorgtaken, veelal vrouwen maar zij niet alleen, hebben ook problemen bij het vinden van banen die deze combinatie toestaan. De aansluitingsproblemen komen tot uitdrukking in de lagere participatie van deze drie groepen. Van een flexibele arbeidsmarkt die tevens waarborgen biedt voor werkzekerheid op een passend niveau, mag verwacht worden dat deze problemen kunnen worden weggenomen. In lijn met het normatieve kader uit hoofdstuk 1 wordt ook hier het uitgangspunt gevolgd dat met voorrang geïnvesteerd moet worden in de capabilities van mensen.

\subsubsection{OUDERE WERKNEMERS}

Oudere werknemers vormen als regel geen aantrekkelijke doelgroep voor werkgevers. Als er gedwongen ontslagen zijn, zouden oudere werknemers hiervoor vaak worden voorgedragen, als het 'lifobeginsel' (last in, first out), dat inmiddels is opgevolgd door het afspiegelingsbeginsel, dit niet zou verhinderen. Eenmaal ontslagen zijn werkgevers niet snel geneigd hun een nieuwe baan aan te bieden. Dat deze situatie tot nu toe niet tot onoverkomelijke problemen heeft geleid, komt omdat er vele uittredingsroutes waren. Niet alleen de vut maar ook de WAO is intensief benut voor oudere werknemers, terwijl ook de wW - aangevuld met bovenwettelijke tegemoetkomingen - een aantrekkelijke mogelijkheid was, zeker in combinatie met een vrijstelling of een soepel regime ten aanzien van de sollicitatieplicht. In de nabije toekomst zijn deze drie routes zo niet meer bruikbaar. Vervroegde uittreding moet in toenemende mate betaald worden op basis van 
een per individu actuarieel neutraal budget. De WAO is met de herziening van het schattingsbesluit en met de introductie van de WIA uitsluitend toegankelijk voor personen met een medische beperking. De duur van de WW voor ouderen is teruggebracht tot 38 maanden zonder generieke uitzonderingen ten aanzien van de sollicitatieplicht. Toch hoeft de toekomst niet per se onheilspellend te zijn. OECD-landen zonder uittreedroutes voor ouderen slagen erin om hen te laten participeren, zonder noemenswaardige werkloosheid (OECD 2006a: 67).Wat is er nodig om de voorwaarden voor volledige werkgelegenheid voor ouderen te verkrijgen?

Om dit onderwerp te bespreken wordt opnieuw onderscheid gemaakt naar interne en externe mobiliteit. De problemen die ouderen thans ontmoeten, worden vooral zichtbaar na ontslag. Eenmaal ontslagen is het niet gemakkelijk om weer een baan te vinden. Het probleem is er echter natuurlijk al eerder. Dat blijkt uit het feit dat werkgevers graag met voorrang afscheid zouden willen nemen van oudere werknemers. Ouderen die wel een baan hebben, vormen weliswaar nog geen probleem op de open arbeidsmarkt, maar wellicht al wel voor hun werkgever. De belangrijkste verklaring voor de thans weinig rooskleurige positie van ouderen op de arbeidsmarkt is gelegen in de hoge loonkosten. De hoge kosten van oudere werknemers zijn vooral het gevolg van de beloningssystemen. Loonschalen zijn niet neerwaarts aan te passen. Lonen stijgen niet zelden met de lengte van het dienstverband en dus met de leeftijd.

Waarom zijn ouderen niet meer altijd het loon waard, dat hun eerder met graagte is toegekend? Dat komt omdat hun productiviteit is afgenomen. Dit heeft verschillende oorzaken. Veel oudere werknemers hebben lange tijd in hun ontwikkeling stilgestaan. Hun vakopleiding is verouderd en hun vermogen en ambitie om nieuwe technieken te leren hanteren zijn beperkt. En er is weinig geïnvesteerd in hun arbeidsvaardigheden en men is slecht voorbereid op mogelijke wendingen in de loopbaan. Daarnaast is hun lichamelijke conditie niet meer dezelfde. De belastbaarheid daalt met de jaren en de gezondheidsrisico's nemen toe.

Tegenover deze nadelen staan ook voordelen. Ouderen hebben veel werkervaring. Voorts hebben ouderen voordelen voor het bedrijf waar ze werken vanwege de specifieke kennis van producten en processen van dat bedrijf, en de netwerken van afnemers en toeleveranciers. In veel gevallen wegen deze voordelen niet op tegen de nadelen. Maar ontslagbescherming verhindert dat de werkgever met voorrang afscheid neemt van de oudere werknemers. Daarom worden de problemen pas manifest bij gedwongen ontslagen om bedrijfseconomische redenen, waarbij ouderen, naar evenredigheid, voor ontslag kunnen worden voorgedragen. Maar, zoals gezegd, de problemen beginnen daar niet. Onderzoek van Van Praag en Hop toont aan dat structureel ruim de helft van de ontslagen oudere werknemers bij een nieuwe werkgever geen baan vindt tegen het oude loon (Van Praag en Hop 1996: 36). Waarom wordt de oudere werknemer dan toch in dienst gehouden? Dit heeft twee oorzaken. Het in dienst houden van een oudere werk- 
nemer betekent dat de werkgever geen kosten hoeft te maken voor een ontslagprocedure. Daardoor is de oude werkgever bereid de oudere werknemer met een langdurig dienstverband toch aan te blijven houden. Ten tweede profiteert de werkgever van de bedrijfsspecifieke kennis, die verloren gaat bij ontslag. Beide elementen zijn niet relevant voor een werkgever die overweegt om een solliciterende oudere in dienst te nemen. Daarom zal een nieuwe werkgever een loon aanbieden dat, aldus het genoemde onderzoek, voor de helft van de groep vanaf 55 jaar lager is dan het loon bij de oude werkgever. Daarmee dreigen oudere werknemers die door omstandigheden hun baan kwijtraken, van goed beschermde insiders permanente outsiders te worden.

Ontslagbescherming voor oudere werknemers verhindert dat hun afnemende productiviteit wordt doorvertaald naar een lager loon. Demotie, de overgang naar een lichtere functie met een dienovereenkomstig lager loon, betekent immers ontslag uit de oude functie en aanstelling in een nieuwe. Tenzij er sprake is van vrijwillige medewerking (waarbij de oudere werknemer opteert voor vrijwillig ontslag in ruil voor een nieuwe baan), kan demotie niet worden gerealiseerd. Een demotiebeleid is in Nederland, en in de andere EU-landen, dan ook geen algemeen verschijnsel.

In paragraaf 7.4 is voorgesteld om het ontslagstelsel te laten opgaan in een samenstel van maatregelen waardoor via preventie en samenvoeging van inkomensbescherming en reïntegratie-inspanningen de werkzekerheid wordt vergroot. De raad meent dat dit model ook voor ouderen een essentiële verbetering inhoudt. Het bijhouden van nieuwe technieken en vaardigheden wordt dan, in het kader van het eigen loopbaanperspectief, een gangbare praktijk. Tegelijkertijd moet interne mobiliteit van de grond komen. Het risico van vastgeroest raken in een baan met steeds dezelfde functievereisten, vermindert dan.

Een andere kostenfactor die we bespraken is de afnemende belastbaarheid. Daar kan een oplossing voor gevonden worden door werken in deeltijd te vergemakkelijken. Zoals in hoofdstuk 6 is beschreven, werkt maar liefst de helft van de oudere mannelijke werknemers in deeltijd. Van de ouderen die nog willen werken, wil twee derde een deeltijdbaan ( CBS 2006: 57). Omdat mannen in de afgelopen decennia in overgrote meerderheid in voltijdbanen werkten, is dit een verandering die, anders dan demotie, kennelijk wel gemakkelijk is te organiseren. Blijkbaar wil men hiervoor wel inkomensoffers brengen. Het blijkt dus dat verlichten van de omvang van de baan een hogere prioriteit geniet dan een verlichting van de inhoudelijke zwaarte van de baan. Blijft over het gezondheidsrisico, waartegenover de grotere werkervaring staat, en, bij interne mobiliteit, het voordeel van bedrijfsspecifieke kennis. Ook kan leeftijdsdiscriminatie een rol spelen. Leeftijdsdiscriminatie bij werving en selectie is onderdeel van de cultuur die wordt gekenmerkt door een voorkeur voor jongere werknemers. Zoals besproken komt deze voorkeur vermoedelijk voort uit kostenbewustzijn. In de hier voorgestelde aanpak kan het kostennadeel worden gemitigeerd. Het tegengaan van dan nog resterende leeftijdsdiscriminatie is wenselijk voor het effectief 
creëren van een arbeidsmarkt voor oudere werknemers. Leeftijdsdiscriminatie is lastig aan te pakken, want het is in individuele gevallen moeilijk hard te maken. De Wet gelijke behandeling op grond van leeftijd bij de arbeid (WGBL) uit 2004 verbiedt discriminatie bij onder meer de werving en selectie van werknemers. Via monitoren kan inzicht worden verkregen in het aannamebeleid van bedrijven. Als zou blijken dat ouderen stelselmatig ondervertegenwoordigd zijn, zou dit probleem geagendeerd moeten worden, met het oog op het nemen van maatregelen.

Zoals al vaker is opgemerkt vergt een beleid gericht op het investeren in capabilities een opbouwfase. De hier voorgestelde combinatie van preventie en integratie is pas effectief als werknemers van dit beleid hebben kunnen profiteren. Voor oudere werknemers van nu zal dit weinig soelaas meer bieden, terwijl anderzijds de maatregelen die de bestaande uittrederoutes niet langer openstellen, al genomen zijn. Op korte termijn kan dit tot problemen leiden. Daarom adviseert de raad hier, voor de generatie die nu tot de ouderen gerekend worden, de mogelijkheid voor van een fiscale tegemoetkoming die hen in staat zou stellen om zonder inkomensverlies te opteren voor een vierdaagse werkweek dan wel een vijfdaagse werkweek tegen een lager loon. In België is de mogelijkheid van een publiek gefinancierde vrije dag per week recentelijk overeengekomen (EIRR). Een dergelijke maatregel heeft het risico van een grote deadweight-loss: degenen die al gekozen hebben of die zonder problemen hun functie uitoefenen, zouden ook zo'n meevaller krijgen. Dat maakt de keuze voor een algemene variant minder logisch.

Een geclausuleerde variant, waarbij zo'n tegemoetkoming niet algemeen maar slechts na gedwongen ontslag beschikbaar zou zijn, zou deze risico's verminderen. Het gaat dan vermoedelijk om enkele duizenden personen per jaar. Een verdere toespitsing kan worden verkregen door alleen de lagere inkomensgroepen aan zo'n regeling te laten deelnemen. Voor hen weegt een inkomensachteruitgang het zwaarst, terwijl juist in deze categorie de lasten van fysieke arbeid een voortzetting van het oude beroep kunnen bemoeilijken. Een nadeel van deze beperking is wel dat degenen die intern van baan veranderen er niet van profiteren. Alles afwegend adviseert de raad bij wijze van overgangsregeling voor zo'n tegemoetkoming voor ouderen. Tegenover de kosten van zo'n maatregel staan de opbrengsten van een geringer beroep op de ww, omdat de tegemoetkoming uitsluitend ten goede komt aan werkenden. Als het jarenlang mogelijk was om ongeveer zeventig procent van de werknemers ouder dan 60 jaar van een volledig inkomen te voorzien, zonder enigerlei tegenprestatie in de vorm van betaald werk, moet het ook mogelijk zijn een tegemoetkoming ter waarde van het inkomen van een dag per week te fourneren, als daartegenover vier werkdagen staan. Naarmate het hierboven bepleite voorstel ingang zal hebben gevonden, en daarmee het bevorderen van de employability ook voor ouderen een 'going concern' is geworden, zal de noodzaak van zo'n regeling geringer worden en uiteindelijk vervallen. Voor volgende generaties zal de implementatie van employabilityversterking ook eenvoudiger zijn, omdat hun opleidingsniveaus gunstig afsteken ten opzichte van die van de huidige ouderen. Vandaar dat zo'n overgangsregeling 
van een heldere horizonbepaling kan worden voorzien. Een tijdsduur van tien jaar, waarbinnen degenen die nu jonger zijn dan 55 jaar zich kunnen aanpassen aan de nieuw te ontwikkelen mogelijkheden, ligt dan in de rede.

Met een beleid langs deze lijnen meent de raad dat de arbeidsmarktvooruitzichten (in termen van 'werkzekerheid') voor oudere werknemers verbeterd kunnen worden. Wanneer de toerusting van oudere werknemers om een nieuwe baan te vinden is verbeterd, zal er behoefte ontstaan aan een goed werkende arbeidsmarkt voor ouderen. De CWI's zouden zich kunnen inspannen voor deze relatief nieuwe doelgroep, en landelijke of regionale initiatieven kunnen promoten en aanvullen vanuit de eigen expertise. Het gevoel van urgentie dat vanwege de jeugdwerkloosheid heeft geleid tot een Taskforce, zou ook voor de ouderen niet misstaan.

Het in paragraaf 7.4 voorgestelde samenstel van maatregelen ter vergroting van de werkzekerheid, houdt ookvoor ouderen een essentiële verbetering in. De voorstellen voor werkzekerheid bieden vooral soelaas voor de volgende generaties oudere werknemers. Voor de huidige generatie oudere werknemers is invoering van een fiscale tegemoetkoming wenselijk, die hen na ontslag in staat stelt om zonder al te groot inkomensverlies te opteren voor een vierdaagse werkweek of voor een vijfdaagse werkweek tegen een lager brutoloon. Ook is aandacht nodig voor leeftijdsdiscriminatie.

\subsubsection{ZORGENDE WERKNEMERS}

Ook werknemers met kinderen lopen vanwege de onvermijdelijke verdeling van prioriteiten tussen werk en gezin een extra risico ten aanzien van hun werkzekerheid. De onderbroken of de verminderde participatie van werknemers met kinderen heeft op de lange termijn gevolgen voor hun loopbaan. Doordat het zwaartepunt van de zorgperiode vaak samenvalt met de periode waarin de werknemer cruciale stappen moet zetten voor opwaartse mobiliteit in het vervolg van de loopbaan, nemen de kansen op opwaartse mobiliteit af. Zorgende werknemers hebben daardoor in hun latere loopbaan een lager loon dan gemiddeld en participeren minder dan gemiddeld in voltijd wanneer daar, gelet op de combinatie van zorg en werk, wel ruimte voor bestaat. Het probleem met deze groep is niet zozeer gelegen in tekorten aan capabilities als wel in belemmeringen om deze te benutten.

In het recente WRR -rapport De verzorgingsstaat herwogen wordt uitvoerig ingegaan op de zorgtaken voor ouderen. Bijna 13 procent van de bevolking ouder dan 18 jaar verleent zorg aan vooral oudere familieleden. Deze vorm van zorgverlening wordt vaak gecombineerd met een deeltijdbaan. Een ander probleem wordt gevormd door de dalende vruchtbaarheidsgraad, hetgeen in verband wordt gebracht met de hoeveelheid betaalde arbeid. Een flexibele arbeidsmarkt zal daarom deze combinaties van werk met zorgen voor kinderen en ouderen moeten accommoderen. In het voornoemde rapport wordt bepleit dit niet in financiële zin te regelen (via spaarloon en levensloopregelingen), maar primair door het mogelijk blijven maken van deeltijdbanen en door goede verlofregelingen. Een te kleine 
deeltijdbaan kan de carrièremogelijkheden beknotten; bij een deeltijdbaan van vier in plaats van vijf dagen of bij een deeltijdbaan met een verminderde dagelijkse werktijd, lijkt dit risico veel minder groot. Ouders met kinderen zouden om deze reden de gezamenlijk gewenste zorgdagen beter kunnen delen dan ze bij een van de partners te concentreren.

In het licht van de dalende vruchtbaarheidsgraden verdient het de voorkeur een basale vorm van het zorgverlof in financieel opzicht publiek te regelen in plaats van op individuele basis: gezien het lage gemiddelde geboortecijfer per gezin ligt een periode van één jaar zorgverlof per kind in de rede. Met een introductie van keuzevrijheid ten aanzien van het gebruik van deze voorziening kan bijgedragen worden aan het vergemakkelijken van het combineren van arbeid en zorg, waarbij mogelijk ook de aanwending in andere fasen van de levensloop betrokken kan worden. Met betrekking tot kinderopvang wordt, conform het rapport over de verzorgingsstaat, een voor iedereen gemakkelijk toegankelijke basisvoorziening bepleit.

In het recente rapport 'De verzorgingsstaat herwogen' is gepleit voor verruiming van zorgverlof en voor kinderopvang als basisvoorziening. Deze maatregelen zullen de combinatie van zorg en werk vergemakkelijken en aldus ook een positieve invloed hebben op de allocatie en de participatie op de arbeidsmarkt.

\subsubsection{WERKNEMERS AAN DE ONDERKANT}

\section{Aanpassen van loonkosten versus investeren in productiviteit}

Werknemers met minder opleiding ondervinden vaker dan werknemers met meer opleiding de negatieve gevolgen van de arbeidsmarktdynamiek. Zij zijn daar slecht tegen gewapend. Om de werkloosheid onder laagopgeleiden tegen te gaan wordt met enige regelmaat bepleit om het minimumloon te verlagen. Discussies in ons land over een lager minimumloon zijn altijd losgekoppeld van het uitkeringsniveau. Toch is het juist de vraag wat er gebeurt met het sociaal minimum als echt relevante factor als het gaat om de effectiviteit van een verlaging van het minimumloon. De Mooij laat zien dat zowel een verlaging van het minimumloon als van het sociaal minimum grote werkgelegenheidseffecten heeft, maar dat het effect van uitsluitend een verlaging van minimumloon verwaarloosbaar is (o.8 respectievelijk o.1 procent, De Mooij 2006: 83). Echter, een simultane verlaging van het minimumloon en de uitkeringen (anders dan via ontkoppeling) is nooit voorgesteld. Een verlaging van uitsluitend het minimumloon in Nederland zal, zo werd in het vorige hoofdstuk besproken, enerzijds wat werkgelegenheid creëren, anderzijds meer uitkeringsontvangers. Het uitkeringsalternatief wordt dan immers relatief aantrekkelijker. Vanwege de aanwezigheid van de armoedeval zullen personen die de kostwinner zijn, meer nog dan nu het geval is in de uitkeringsregelingen terechtkomen.

Uit Britse en Amerikaanse ervaringen blijkt dat een compenserende maatregel in de vorm van een earned income tax credit (EITC), die dan wel op deze groep van 
kostwinners toegesneden zou moeten worden, zeker nuttig is in termen van arbeidsparticipatie en armoedebestrijding, maar ook niet zonder risico's. Weliswaar verslechtert dan niet het netto-inkomen dat met een brutominimumloon wordt verkregen, maar wel verslechtert het perspectief om aan dit laagste loonniveau te kunnen ontsnappen. Immers, een loonstijging die boven de grens van het EITC uitkomt, zal tot een afbouw van deze subsidie leiden. De kans om aan de armoedeval te ontsnappen wordt dan kleiner. Een EITC dat niet wordt gecombineerd met een verlaging van het minimumloon zal de armoedeval wel verlichten, mits deze inkomensverbetering niet wordt doorvertaald naar de uitkeringen.

Verlaging van het wettelijke minimumloon acht de raad niet alleen ten principale onwenselijk, maar levert ook op de korte termijn weinig op. Het verdringen van laagopgeleiden door beter opgeleiden die al een andere bron van inkomen hebben, zal er alleen maar door toenemen. In combinatie met een EITC zou dit nadeel kunnen worden beperkt, maar dit vereist een erg fijnmazige vormgeving, zo bleek in hoofdstuk 6 .

Net zoals het sociaal minimum vertegenwoordigt ook het minimumloon bovendien een normatieve standaard van beschaving die in ons land niet onderschreden zou moeten worden. Werknemers die onder deze norm zitten, moeten door scholing en werkervaring naar het gewenste niveau van productiviteit gebracht worden. Daarvoor zijn grote inspanningen van een reïntegratieapparaat zowel denkbaar als gerechtvaardigd. Er zal een gedifferentieerd aanbod van trajecten moeten worden ontwikkeld om de diversiteit aan achterstanden weg te werken. Met de invoering van de WwB hebben veel gemeenten gekozen voor de Work First-benadering. Daarmee is ook een prioriteit ontstaan voor het aan een baan helpen van de meest kansrijken. Deze aanpak heeft ook nadelige consequenties. De minst kansrijken krijgen immers de minste aandacht (RWI 2006a: 53). Zij staan helemaal onder aan de reïntegratieladder. Als voor hen de stap naar een reguliere baan te hoog is, zal in eerste aanleg moeten worden volstaan met het aanbieden van ander werk. Om de reïntegratie te bevorderen is het gewenst dat jongeren beschikken over startkwalificaties. Nederland heeft in dit opzicht een grote inhaalslag te maken (WRR 2006: 193-196).

Werkervaringsplaatsen kunnen vertrouwdheid met het arbeidsproces herstellen. Gemeenten zouden zich hiervoor moeten inspannen (SzW 2006: 45). Gemeenten hebben hiervoor ook de middelen (in 2005 betrof het overschot op het zogenaamde W-deel ruim 500 miljoen euro, RWI 2006: 49). Werkervaringsplaatsen vertonen de beste uitstroom naar reguliere betaalde banen (SCP 2006: 83-88). Met deze uitstroom vervalt het belangrijkste bezwaar tegen gesubsidieerde arbeid zoals dat uit de internationale literatuur tevoorschijn komt. Het bevorderen van de uitstroom ondervindt veel baat van regionale netwerken. Participatie van werkgevers uit de regio is hierbij een beslissende succesfactor (RWI 2006: 36 ). Het CWI heeft een dergelijke aanpak met veel succes geëntameerd, zodat gemeenten die zo'n aanpak ontberen, de bestaande goede voorbeelden met vrucht kunnen volgen (SzW 2006: 35). 
Handhaving van het minimumloon is ook van belang vanuit een perspectief van armoedebeleid. Participatie op de arbeidsmarkt onder laagopgeleiden is belangrijk, omdat hiermee sociale integratie wordt bevorderd en sociale uitsluiting wordt tegengegaan. Dit stelt eisen aan de kwaliteit van die participatie. Het creëren van banen op een zo laag loonniveau dat daarmee de doorstroom naar reguliere banen feitelijk onmogelijk wordt, leidt niet tot sociale insluiting. Zonder een substantiële deelname van laagopgeleiden op de arbeidsmarkt blijkt het moeilijk te zijn om de armoede onder de lage inkomensgroepen tegen te gaan (Föster en d'Ercole 2005: 27, 11a).

Investeren in de vereiste kwalificaties vergt wel een lange adem. Voor sociaal zwakkere gezinnen zal interventie op jeugdige leeftijd nodig kunnen zijn. Maar de vraag is ook of er op de lange termijn wel een alternatief is. "In the longer term, improving education and overall well-being for children in the lower part of the ability range is the key", meent Stephen Nickell (2005). De optie geeft mede invulling aan de ruimere uitdaging om de verheffingsfunctie van de verzorgingsstaat nieuw leven in te blazen (WRR 2006: 253). Voor komende generaties is het daarbij vooral zaak om individuele scholingstekorten in een vroeg stadium te voorkomen. Het aanbieden van een vroegtijdige interventie aan gezinnen met kinderen, lijkt hiervoor de beste waarborg te bieden, zo wordt in het vorige hoofdstuk betoogd. Hierbij moet gedacht worden aan bijvoorbeeld een voorschoolse opvang met een accent op het aanreiken van opvoedingselementen die buiten het bereik liggen van sociaal zwakke gezinnen. In de sfeer van het herstel is aandacht voor vroegtijdige schoolverlaters van belang. Voor degenen die hebben afgehaakt van de arbeidsmarkt ten slotte, vormen reïntegratietrajecten de aangewezen weg., waarbij geprofiteerd kan worden van een leeftijdsbewust reïntegratiebeleid (szw 2006: 26).

In aansluiting op de voorrang voor het investeren in capabilities, zijn grote inspanningen op het gebied van scholing en reïntegratie van laagopgeleiden gerechtvaardigd. Deze route is veeleisend, maar draagt bij aan een duurzame maatschappelijke samenhang en vormt een structurele bouwsteen van het beleid gericht op vermindering van armoede. Een verlaging van het minimumloon moet worden verworpen: zij kan weliswaar leiden tot meer banen aan de onderkant van het loongebouw, maar verbetert het langetermijnperspectief voor de groep van laagopgeleiden geenszins.

\section{Laagopgeleiden}

Een belangrijke optie voor laagopgeleiden is voorts het zelfstandig ondernemerschap. In 2005 hebben naar raming ongeveer 75.000 personen een bedrijf gestart. Allochtonen zijn in deze groep oververtegenwoordigd. Persoonlijke eigenschappen blijken doorslaggevend te zijn voor het starten van een eigen bedrijf. Het opleidingsniveau is minder bepalend. Uitkeringsgerechtigden nemen onder starters een opvallende plaats in: 10 procent in 2004. De belangrijkste problemen die men ontmoet betreffen de financiering, de regelgeving en gebrek aan ervaring (Velden et al. 2006: 31-40.). Het blijkt dat uitkeringsontvangers die een eigen 
bedrijf beginnen minder snel terugvallen in uitkeringsafhankelijkheid dan degenen die werknemer worden. In de bijstand is een voorziening voor starters; zij kunnen hun inkomsten combineren met een uitkering (voor zover deze het maximum van de uitkering niet te boven gaan) en ze kunnen in aanmerking komen voor een krediet en begeleiding. In de WW is medio 2006 een regeling ingevoerd om een onderneming te starten in combinatie met een wW-uitkering. Eerder stond het beschikbaarheidsvereiste dat in de weg.

Veel allochtonen hebben arbeidsmarktkwalificaties waardoor zij aangewezen zijn op het laagste segment. In zoverre zijn de hier gepresenteerde aanbevelingen bij uitstek ook op hen van toepassing. Maar behalve de kernmerken van laagopgeleiden in het algemeen kunnen allochtonen daarnaast nog andere tekorten vertonen die voor hen de toetreding tot de arbeidsmarkt extra bemoeilijken. In hoofdstuk 6 is gewezen op de ontwikkeling die aangeeft dat tegenwoordig niet zozeer cognitieve vaardigheden centraal staan, maar dat vooral ook zaken als sociale vaardigheden, taalbeheersing, loyaliteit en motivatie een rol spelen bij het werven van personeel. Wanneer er voor allochtonen op deze terreinen leerwensen bestaan, dienen naar de mening van de raad middelen te worden gereserveerd om hierin te voorzien. Een doelgroepenbeleid wordt echter niet aanbevolen. Naast afstanden tot de arbeidsmarkt speelt vermoedelijk ook discriminatie een rol (WRR 2006: 205). Dit ondanks het feit dat een derde van de bedrijven een voorkeursbeleid heeft waarbij allochtonen de meeste prioriteit genieten. Daarom ligt een serieuzer antidiscriminatiebeleid in de rede (WRR 2006: 217).

Het beleid gericht op substantiële investeringen in scholing en reïntegratie verdient voor allochtonen aanvulling met een streng antidiscriminatiebeleid. Beleid gericht op het stimuleren van zelfstandig ondernemersschap biedt voor deze groep perspectief. Waar evident problemen bestaan, dient voor deze groep ruimte te zijn voor specifieke leerwensen.

\subsection{HET ONTWIKKELEN VAN WERKZEKERHEID ALS LEERPROCES}

\subsubsection{CULTUURVERANDERINGEN}

Hierboven zijn enkele hoofdlijnen geschetst van een bijstelling van het arbeidsmarktbeleid op grond waarvan transities op en naar de arbeidsmarkt gemakkelijker kunnen plaatsvinden. Dit is van belang voor onze productiviteit en ons concurrentievermogen, maar ook voor de participatie. Het helpt bovendien om de veranderlijkheid als gevolg van de globalisering op te vangen, en de gevolgen van de vergrijzing te accommoderen. Bij het aangeven van een nieuwe route is onderscheid gemaakt tussen preventie en integratie. Preventie betreft alle inspanningen om voorbereid te zijn op mobiliteit, integratie betreft de bundeling van maatregelen om te voorkomen dat een dreigend ontslag tot werkloosheid leidt. Het is duidelijk dat voorkomen beter is dan genezen, zeker wanneer dat voorkomen gebaseerd is op empowerment en eigen regie. Beter voor de werknemer en de werkgever en beter voor de economie. Het betekent ook dat een gewenst carrière- 
verloop, het werken in afwijkende arbeidspatronen en het combineren van arbeid en zorg gemakkelijker realiseerbaar worden. In de afgelopen decennia is veel werk gemaakt van onder andere het doen welslagen van een op activering gerichte sociale zekerheid. De leuze ‘Werk boven inkomen’ markeert de jarenlange inspanningen om dit streven ingang te doen vinden, niet alleen maatschappelijk maar ook qua keuze van instrumenten. Voor de hier bepleite weg, van curatieve compensatie naar preventieve toerusting, is nog meer cultuurverandering nodig. De vanouds geprefereerde inkomens- en baanzekerheid moeten immers plaatsmaken voor een minder tastbare werkzekerheid. De daarvoor benodigde instituties moeten dan wel op een niveau presteren dat het vertrouwen ook werkelijk kan schragen.

\subsection{2 'NIEUWE RISICO'S'}

Een belangrijke steun voor het realiseren van werkzekerheid kan, naast de noodzakelijke herijking en onderlinge afstemming van instituties, worden gevonden in een vernieuwing in het sociale beleid. Zoals werd opgemerkt hebben de zogenaamde 'nieuwe risico's' (combinatie van arbeid met werk of scholing) weliswaar ingang gevonden in het stelsel van sociale zekerheid, maar vooralsnog op een bescheiden niveau. Het combineren van arbeid en zorg is slechts bescheiden belegd met budgettaire middelen, en dat geldt ook voor de ondersteuning van tussentijdse (bij)scholing en de overgang van school naar werk. Verdere vernieuwingen zijn gewenst zoals het ontwikkelen van scholingsfaciliteiten of leerrechten voor werknemers met een arbeidsrelatie (uitzendbanen, tijdelijke arbeidscontracten) waarbij de werkgever niet in scholing voorziet.

De belangstelling voor de nieuwe risico's is ontstaan in een periode waarin ook het beroep op de oude klassieke zekerheden (inkomensbescherming uit hoofde van bijstand, wW en WAO) veel te hard groeide. Onder die omstandigheden was het verre van eenvoudig de nieuwe risico's institutioneel te beleggen met overheidsvoorzieningen. Van de door Günther Schmid onderscheiden zes nieuwe risico's zijn er vier die in dit rapport centraal staan: de transitie van school naar werk, (bij)scholing, de laagopgeleiden en de oudere werknemers. De andere twee, die samenhangen met levensloop en partnerkeuze, kunnen ook van invloed zijn op de (wijze van) participatie op de arbeidsmarkt (WRR 2006: 158). In een recente studie illustreert Schmid welke intensiveringen deze nieuwe risico's behoeven. Hij noemt als voorbeeld het Zweedse programma voor laagopgeleiden die scholing en training krijgen aangeboden, dit ongeacht hun arbeidsmarktstatus en leeftijd. Voor Nederland zou dit programma een jaarlijkse investering van 700 miljoen vergen en inhouden dat 200.000 personen meer aan opleidingen zouden deelnemen (Schmid 2006). Maar ook de in paragraaf 7.3 en 7.4 beschreven scholingsinspanningen verdienen ondersteuning, in welk verband recentelijk de introductie van een scholingsverlofkorting is voorgesteld, naar analogie van de ouderschapsverlofkorting (Wetenschappelijk Instituut voor het CDA: 81). In paragraaf 7.4 wordt nog een andere intensivering gesuggereerd, te weten een aanwending van $\mathrm{WW}$-middelen die vrijkomen vanwege de hier voorgestelde aanpak, ten 
behoeve van de employability. In dit verband wordt ook verwezen naar hoofdstuk 6 waarin een aantal mogelijkheden is besproken om het risico van moral hazard in de ww te beperken.

Investeren in beperking van de 'nieuwe risico's' levert een belangrijke bijdrage aan werkzekerheid.

\subsubsection{AANPASSINGEN IN DE ARBEIDSORGANISATIE EN HET ARBEIDS- VOORWAARDENOVERLEG}

In paragraaf 7.3 en 7.4 is ervan uitgegaan dat de uitwerking van het levenslang leren als zodanig, en als voorzorg voor een mutatie van baan naar baan, vormgegeven wordt in de arbeidsorganisatie. Dan kan op adequate wijze invulling worden gegeven aan de wensen en mogelijkheden van de werknemers, de bedrijfsorganisatie en de regionale omstandigheden.

De hierboven genoemde cultuuromslag, de verwachtingen ten aanzien van de individuele werknemer met betrekking tot de invulling van het loopbaanperspectief en het omgaan met leerrechten en -plichten, de aansluiting met de herijkte instituties, en de inhoudelijke wijzigingen voor de arbeidsorganisaties, vormen gezamenlijk een grote uitdaging voor alle betrokken partijen. Nog maar enkele decennia terug kon een vakman met dezelfde instrumenten aan de slag waarvan zijn vader zich ook bediende. De kans dat zoon of dochter thans gedurende hun werkzame leven met hetzelfde instrumentarium uit de voeten kunnen, is inmiddels minimaal geworden. Die ontwikkeling vormt een grote uitdaging voor de werknemer en daarmee ook voor de arbeidsorganisatie. Ook de druk die uitgaat van zzp'ers (zelfstandigen zonder personeel) voor meer handelingsvrijheid, kan beschouwd worden als een illustratie van de behoefte aan flexibiliteit waarin de gebruikelijke arbeidspatronen onvoldoende voorzien.

In hoofdstuk 6 is gebleken dat veel vernieuwingen hun weg naar cao-bepalingen hebben gevonden, maar ook is gebleken dat deze bepalingen in niet weinig gevallen geen follow-up hebben gekregen. En ook lijkt het erop dat verdere verbeteringen uitblijven. Ook voor het MKB, die voor de hier bepleite aanpak sectorale en branchegewijze uitwerkingen nodig heeft, geldt dat de initiatieven in deze sfeer, alhoewel aansprekend, nog verre van algemeen zijn. Het begeleiden van grote veranderingen in het arbeidsproces door passende afspraken in het arbeidsvoorwaardenoverleg, stelt hoge eisen aan beide partijen. In het verleden zijn er weinig voorbeelden die aangeven dat dit proces gemakkelijk van de grond is te trekken (Korevaar 2000: 207).

Niet zelden is de moeilijkheid om tot een vernieuwend personeelsbeleid te komen afgekocht met financiële tegemoetkomingen. Innovatief arbeidsvoorwaardenoverleg zal moeten inspelen op het vernieuwende vermogen van de arbeidsorganisatie, tegelijkertijd met het vormgeven van op individuen afgestemde scholingstrajecten. Het verbinden van de arbeidsorganisatie met de arbeidsvoorwaarden vraagt ook aan werkgevers een verruiming van het overleg. Voor de 
vakbeweging betekent dit een definitiever afscheid van een traditionele behartiging van belangen van traditionele werknemers. "Als vakbonden ook in de toekomst de beste willen zijn, moeten zij erin slagen om nieuwe items sneller te ontwikkelen en sneller uit te voeren", schrijft Korevaar (2000: 294). Deze fundamentele vraagstukken vragen om een nieuwe sleutelrol. Het behouden en opnieuw verwerven van die sleutelrol vergt een intensieve leerweg. Om het welslagen van deze vorm van sociale innovatie mogelijk te maken, wijst de raad in onderstaande paragraaf op de mogelijkheid van een ingroeimodel voor het bereiken van het in paragraaf 7.3 en 7.4 beschreven doel. Conform dit doel zou ook in een ingroeimodel het ontslagrecht onderdeel uitmaken van het samenstel van aanpassingen. Daarom wordt in de onderstaande paragraaf ook op de actuele aspecten van dit dossier ingegaan.

Geconfronteerd met de nieuwe ontwikkelingen op de arbeidsmarkt en binnen de arbeidsorganisatie, verwacht de raad dat het arbeidsvoorwaardenoverleg traditionele oriëntaties zal weten in te ruilen voor innovatieve cao-afspraken waarmee deze en toekomstige ontwikkelingen kunnen worden geaccommodeerd.

\subsubsection{EEN INGROEIMODEL ALS OVERGANGSFASE}

Het dossier van de ontslagbescherming vraagt op korte termijn om nadere aanpassingen. Het zou te betreuren zijn als deze aanpassingen niet vooral in het teken zouden staan van het versterken van de werkzekerheid. Het geïsoleerd bezien van het ontslagrecht leidt immers tot minder interessante opties. Eén optie is het versoepelen en vereenvoudigen van de ontslagbescherming door ontslag toe te staan wanneer een ontslagvergoeding wordt uitbetaald, zoals door Blanchard en Tirole (2004) is voorgesteld, maar deze bevordert de werkzekerheid in het geheel niet. Wel ontstaat het risico van werkloosheid en afwenteling. Immers, een versoepeling van het ontslagrecht samen met een verlaging van de ontslagvergoeding, maar zonder complementen in de sfeer van de employability, zal leiden tot een stijging van het beroep op de ww. Een andere optie, het vervangen van het huidige stelsel van ontslagbescherming, dat wordt gekenmerkt door dualiteit en een preventieve toets, door een enkelvoudige repressieve toets, lijkt om meerdere redenen een grote stap. Ten eerste mag op basis van het beschikbare onderzoeksmateriaal niet worden aangenomen dat dit tot substantiële effecten leidt voor wat betreft de participatie op de arbeidsmarkt. Ten tweede is het de vraag of het tegemoetkomt aan de problemen die er zijn met betrekking tot het ontslagstelsel. Deze problemen doen zich immers vooral voor, zo bleek in hoofdstuk 6 , met betrekking tot de ontslagen om persoonlijke omstandigheden die samenhangen met het functioneren. De andere ontslaggronden, die het overgrote deel uitmaken, ontmoeten veel minder procedurele bezwaren.

Ontslagen vanwege het persoonlijk functioneren (verwijtbaar gedrag, disfunctioneren, verstoorde arbeidsrelatie) zouden daarom bij wijze van overgangsfase volgens de opzet die in paragraaf 7.4.1 is geschetst, kunnen worden afgewikkeld. 
Dit zou betekenen dat ontslagen op deze gronden dan zonder tussenkomst van CWI en/of kantonrechter worden toegestaan, mits de betrokkene tijdig en met inachtneming van een nader vast te stellen zoektijd, over dit voorgenomen ontslag is geïnformeerd. Een derde conditie wordt gevormd door deze mogelijkheid alleen open te stellen voor die werkgevers die cao's zijn overeengekomen waarin invulling is gegeven aan de reïntegratie-inspanningen welke gedurende de zoektijd van toepassing zijn. Het ligt in de rede om bij deze afspraken ook aandacht te schenken aan preventieve vormen van investeringen in employability waarvan in subparagraaf 7.4.2 een aantal modaliteiten is besproken. In dit kader zou de Stichting van de Arbeid een stramien kunnen ontwikkelen ter ondersteuning van het gedecentraliseerde overleg. Inbreng van de middelen en expertise van het UWV is gewenst om de reïntegratie maximale kans van slagen te geven. Zoals opgemerkt zou de zoektijd dienen te variëren met de duur van het dienstverband, waarmee de duurafhankelijkheid van de ontslagvergoeding wordt getransponeerd naar die van de zoektijd. De ontslagvergoeding wordt dan, voor deze categorie, ingeruild voor investeringen in employability en reïntegratieondersteuning en in de loondoorbetaling in de zoekperiode.

De met deze laatste drie posten samenhangende kosten maken dat deze nieuwe ontslagroute initieel gezien niet onmiddellijk veel goedkoper zal uitvallen. Een verdringing van de ontslagroutes voor voorgenomen ontslagen vanwege bedrijfseconomische omstandigheden of arbeidsongeschiktheid door deze nieuwe vorm, is dan ook niet op voorhand te verwachten. Besparingen komen immers vooral ex post tot uitdrukking in het niet volledig benutten van de zoekperiode voorafgaand aan de ontslagdatum en het geringere beroep op de ww, alsook in de macro-economische voordelen van een beter functionerende arbeidsmarkt. Niettemin lijkt een passieve registratie van deze nieuwe ontslagroute door het CWI gewenst.

Op deze wijze zou echter al wel praktijkervaring worden verkregen met een toekomstgerichte vorm van ontslagbescherming die geheel in het teken komt te staan van werkzekerheid. Cao-partijen krijgen in zo'n ingroeimodel de gelegenheid optimale employability- en reïntegratie-inspanningen te ontwikkelen. Naarmate deze vorm beter zijn bruikbaarheid bewijst en naarmate in het bedrijfsleven ook de preventieve aanpak wordt toegepast (welke aanpak vooral bij de beteropgeleide jongere jaargangen op de arbeidsmarkt gemakkelijker ingang zal kunnen vinden), kan worden overgestapt naar een generieke invoering. Dan wordt een situatie bereikt waarin de relevante arbeidsmarktinstituties met voorrang zijn afgestemd op het bereiken van werkzekerheid. Het activerende streven van 'Werk boven inkomen', dat nu betekenis heeft in de curatieve fase, is dan al van kracht voordat het risico van werkloosheid actueel is.

Het verdient overweging om in een overgangsfase de in dit hoofdstuk ontwikkelde ontslagroute gebaseerd op drie formele elementen (tijdige aankondiging, inachtneming van de zoektermijn en adequate invulling van de activiteiten tijdens de zoekperiode-zie par.7.4.1) toe te passen voor de kleine categorie van ontslagen wegens 
persoonlijk functioneren, om de bruikbaarheid van deze nieuwe aanpak verder te verkennen en deze lerenderwijs te ontwikkelen.

\subsubsection{DE ESSENTIE VAN WERKZEKERHEID}

Het basisprincipe van de aanbevelingen in dit hoofdstuk is dat structureel wordt geïnvesteerd in de vaardigheden en de inzetbaarheid van de werknemer, waardoor hij of zij gewapend is tegen de risico's van de flexibeler arbeidsmarkt die in verband met een aantal structurele ontwikkelingen onvermijdelijk is. Werknemers hebben de regie van deze investeringen, maar krijgen daarvoor door werkgevers en samenleving middelen aangereikt. Deze investeringen liggen aan de basis van werkzekerheid.

Een beleid van investeren in werkzekerheid ligt in de lijn van activerend en op werk gericht beleid dat al eerder is ingezet, bouwt verder op het streven naar leven lang leren, en maakt gebruik van veranderingen die zichtbaar zijn in vele cao's en in recente aanpassingen in de sociale wetgeving. Deze ontwikkelingen worden in dit rapport gebundeld, beter op elkaar afgestemd en aangevuld en daardoor gesmeed tot een samenhangend beleidspakket voor al die plekken van de arbeidsmarkt waar werkzekerheid in het geding is. Dit is het geval bij de transities van functie naar functie, van baan naar baan en van buiten naar binnen de arbeidsmarkt. In dit rapport wordt voor deze drie plekken een consistent en samenhangend beleidspakket voorgesteld.

Een hoog niveau van werkzekerheid wordt verkregen door op een viertal terreinen de instituties te herijken. Deze betreffen het investeren in leven lang leren en de loopbaanplanning; de inkomensbescherming ten dienste van de werkzekerheid; de bundeling van de reïntegratie-inspanningen en het antwoord bieden op de 'nieuwe risico's'. Deze bestanddelen vormen een samenhangend geheel, dat vervolgens specifiek kan worden uitgewerkt voor het versoepelen van transities van functie naar functie en van baan naar baan.

Bij de overgang van functie naar functie en de interne flexibiliteit binnen bedrijven staat de vormgeving van het loopbaanperspectief centraal. Scholing en opleiding, maar ook jobroulatie, moeten in het verlengde van de ontwikkeling van een loopbaanperspectief liggen. Bepleit wordt dat in cao's afspraken over de ontwikkeling van het loopbaanperspectief worden gemaakt, zodat deze algemene ingang krijgen. Voorts wordt geadviseerd tijd vrij te maken en middelen te investeren in de employability-behoeften in de vorm van opleidingen en cursussen en in ondersteuning bij reïntegratie.

Bij de overgang van baan naar baan is het cruciaal dat de drie vormen van inkomensbescherming, die op dat moment een rol spelen, te weten loondoorbetaling, ontslagvergoeding en ww-uitkering, in samenhang worden bezien. Op die manier kunnen ze beter dan nu worden ingezet bij de overgang naar een andere baan. Wanneer aan drie formele elementen - tijdige aankondiging, inachtneming 
van de zoektermijn en adequate invulling van de activiteiten tijdens de zoekperiode - is voldaan, kan tussenkomst van CWI of kantonrechter bij de ontslagverlening achterwege blijven. Van belang is voorrang te geven aan het benutten van de geschiktheid voor een nieuwe baan, in plaats van aan het compenseren voor de ongeschiktheid van de oude baan. Om lering op te doen met deze vorm van het ontwikkelen van werkzekerheid wordt een ingroeimodel in overweging gegeven waarbij de voorgestelde aanpak vooralsnog beperkt blijft tot de groep van ontslagenen op grond van persoonlijk functioneren. Vanzelfsprekend zullen de reïntegratie-inspanningen bij de overgang van de ene baan naar de andere in het verlengde liggen van de investeringen in employability die eerder in de loopbaan hebben plaatsgevonden. Hierop verder bouwend wordt geadviseerd de reïntegratie-inspanningen van de werkgever, CWI en UWV te bundelen met het oog op de tijdwinst en de effectiviteit.

De afspraken over investeringen in inzetbaarheid en reïntegratie vergen een verankering die in eerste aanleg in cao-afspraken kan worden gevonden. Daarmee wordt ruimte gelaten aan de decentrale, gedifferentieerde invulling die past bij een toekomstige organisatie van de arbeid. Op basis van de contouren van deze afspraken kan vervolgens een kaderwet worden geformuleerd, om de reikwijdte van succesvolle instrumenten meer algemeen te doen zijn.

Bij transities van buiten naar binnen gaat het vooral over het vormgeven van werkzekerheid van groepen die nog te vaak of te lang buiten de arbeidsmarkt staan of een hoge kans lopen buiten de arbeidsmarkt te vallen. Voor oudere werknemers is het up-to-date houden van hun inzetbaarheid van groot belang. Alleen het duurzaam onderhouden van capabilities kan de vooruitzichten voor de volgende aankomende generaties oudere werknemers verbeteren. Voor de huidige generatie ouderen wordt een fiscale tegemoetkoming bepleit die compensatie biedt voor een werkdag per week, omdat blijkt dat niet de inhoudelijke werkdruk maar de wekelijkse werkduur voor ouderen thans het primaire knelpunt vormt.

Voor werknemers die arbeid en zorg combineren wordt een verruiming van het zorgverlof aanbevolen. Voor het verbeteren van het arbeidsmarktperspectief van laagopgeleiden heeft de route van investeren en optillen van hun productiviteit veruit de voorkeur boven de inspiratieloze weg van een verlaging van het minimumloon. De keuze voor investeren in capabilities vergt weliswaar intensieve ondersteuning, maar in feite is er op lange termijn geen andere juiste keuze te maken, wil men de maatschappelijke en inkomenspolitieke samenhang in ons land intact laten. Voor allochtone laagopgeleiden zijn specifieke aanvullingen gewenst. In dit verband (maar dat geldt ook voor andere groepen) verdient het stimuleren van zelfstandig ondernemersschap aandacht. Het beleid dat hier wordt ontwikkeld, biedt ook mogelijkheden voor combinaties van werk, zorg en scholing, en nog ruimer, aangrijpingspunten voor het omgaan met de nieuwe risico's van de moderne arbeidsmarkt. 
De som van de hierboven uitgewerkte beleidsaanbevelingen vormt een samenhangend pakket van investeringen in werkzekerheid. Realisering vereist de nodige veranderingen in de bestaande arbeidsmarktcultuur. De inspanningen die in de afgelopen decennia gericht waren op de activering van de sociale zekerheid en op werk boven inkomen, markeren niet alleen substantiële beleidsveranderingen, maar ook een andere visie op de rol van werk in het leven van burgers en in de samenleving. Voor de hier bepleite weg van investeringen in inzetbaarheid is nog meer cultuurverandering nodig. De vanouds geprefereerde inkomens- en baanzekerheid moet plaatsmaken voor een minder tastbare werkzekerheid. Het hier aangereikte pakket van investering en reïntegratie is zeker niet gemotiveerd door het verdedigen van onhoudbare linies, maar is gericht op het investeren door werknemers, werkgevers en samenleving in de opbouw van het vermogen om adequaat te kunnen inspelen op toekomstige veranderingen.

Werkzekerheid is het antwoord op de uitdagingen van een steeds veranderlijker arbeidsmarkt. Werkzekerheid is echter een hoofdrichting, die in de komende jaren in concrete vormen van uitwerking en inrichting op een zorgvuldige wijze verder gestalte moet krijgen. Werkzekerheid vereist een heroriëntatie en een samenhangende kijk op een aantal van de huidige arbeidsinstituties. Werkzekerheid vereist vooral een investering in de inzetbaarheid van werknemers en van potentiële werknemers die zo vroeg mogelijk begint en een leven lang wordt gecontinueerd. Werkzekerheid betekent een omslag van curatieve interventies naar een structureel op preventie gericht beleid van duurzame inzetbaarheid. Die omslag komt niet vanzelf. De wisselwerking van institutionele aanpassingen en afspraken in het arbeidsvoorwaardenoverleg kan tot steeds betere invullingen leiden. Dit zal de nodige energie vergen. Tegelijkertijd zijn de baten van een beleid van investering in werkzekerheid in economische en sociale termen omvangrijk. Werkzekerheid is een onmisbare bouwsteen in de economie van morgen. 


\section{LITERATUUR}

Acemoglu, D. (2002) 'Technical Change, Inequality, and the Labor Market', Journal of Economic Literature, Vol. XL, 1: 7-72.

Agell, Jonas (2002) 'On the Determinants of Labour Market Institutions: Rent Seeking vs Social Insurance', German Economic Review 3, 2: 107-135.

Andersson, F., H.J. Holzer en J.I. Lane (2005) Moving Up or Moving On, New York: Russell Sage.

Bangma, K.L., P.M. de Jong-'t Hart en P.A. van Eck van de Sluis (2006) Bedrijvendynamiek en werkgelegenheid, Zoetermeer: EIM.

Baris, A. en E. Verhulp (2007) 'Flexibiliteit en ontslagrecht', blz. 131-208 in D. Scheele, J.J.M. Theeuwes en G.J.M. de Vries (red.), Arbeidsflexibiliteit en ontslagrecht, WRR Verkenning 14, Amsterdam: Amsterdam University Press.

Bartelsman E.J. en M. Doms, 200o, 'Understanding Productivity: Lessons from Longitudinal Microdata', Journal of Economic Literature 38, 3: 569-594.

Becker, G. (1994) Human Capital: A Theoretical and Empirical Analysis, with Special Reference to Education, Chicago: University of Chicago Press.

Beer, P. de (1996) Het onderste kwart. Werk en werkloosheid aan de onderkant van de arbeidsmarkt, Den Haag: Sociaal en Cultureel Planbureau.

Bekker, S., P. Ester en T. Wilthagen (2005) Jong en oud op de arbeidsmarkt. Generaties, transities en levensloop, Den Haag: Reed Business Information.

Bekker, S., D. Fouarge en M. Kerhofs (2003) Trendrapport Vraag naar arbeid 2002, OSApublicatie A2oo.

Belot, M. en J. van Ours (2007) 'Arbeidsmarktinstituties en arbeidsmarktdynamiek', blz. 261-294 in D. Scheele, J.J.M. Theeuwes en G.J.M. de Vries (red.), Arbeidsflexibiliteit en ontslagrecht, WRR Verkenning 14, Amsterdam: Amsterdam University Press.

Blanchard, O. en J. Tirole (2004) 'Redesigning the Employment Protection System', De Economist 152: 1-20.

Blinder, A.S. (2006) 'Offshoring: the next industrial revolution?', Foreign affairs 82: 113-128. Blundell, Richard (2006), 'Earned income tax credit policies: Impact and optimality, The Adam Smith Lecture, 2005', Labour Economics 13 (2006) 423-443.

Bolweg, J.F. en A.W. de Korte (1994) De nieuwe werknemer?, Assen: Van Gorcum.

Bonoli, G. \& H. Sarfati (2002) 'Conclusions: the Policy Implications of a Relationship' in H. Sarfati \& G. Bonoli (red.) Labour Market and Social Protection Reforms in International Perspective, Aldershot: Ashgate.

Borea (2006) Brief aan de leden van de Vaste Kamercommissie szw d.d. 24 april 2006 (www.borea.nl).

Bovenberg, L. (2005) Balancing work and family life during the life course, Tilburg: Netspar.

Bradley, David en John D. Stevens (2007) 'Employment Performance in OECD Countries: A Test of Neo-Liberal and Institutional Hypotheses', Comparative Political Studies, 40 (12) (nog niet gepubliceerd).

Brouwer, P., M.H.H. van Lin en W.S. Zwinkels (2001) Inzetten op inzetbaarheid. Employability in organisaties, Tilburg: OSA. 
Bureau Bartels (2006) Onderzoek ontslagrecht ervaren door werkgevers (onderzoek in opdracht van szw).

Castells, M. (1996) The Rise of the Network Society, Malden, Mass.: Blackwell Publishers.

Centraal Bureau voor de Statistiek (2001) Meer opleidingen in het bedrijfsleven, CBSwebpublicatie.

Centraal Bureau voor de Statistiek (2003) Ruim negen jaar bij dezelfde baas, CBS-webpublicatie.

Centraal Bureau voor de Statistiek (2006) 'Hoeveel ouderen willen werken', Sociaaleconomische trends, 2006, afl. 4, Voorburg: CBS.

Centraal Planbureau (1999) Macro Economische Verkenning 1999, Den Haag: CPB.

Centraal Planbureau (2000) Centraal Economisch Plan 20oo, Den Haag: Sdu Uitgevers.

Centraal Planbureau (2004) Arbeidsmarktberichten, Den Haag: Sdu Uitgevers.

Centraal Planbureau (2004a) 'Towards efficient unemployment insurances in the Netherlands', СРВ Memorandum.

Centraal Planbureau (2006) Centraal Economisch Plan 2006, Den Haag: Sdu Uitgevers.

Centraal Planbureau (2006a) Macro Economische Verkenning 2007, Den Haag: Sdu Uitgevers.

Centraal Planbureau (2006b) 'Vrij verkeer werknemers nieuwe EU-lidstaten', СР В Notitie, 3 april 2006.

Commissie-Rood (Adviescommissie Duaal Ontslagstelsel) (200o) Rapport van de Commissie Duaal Ontslagstelsel.

Dalen, H. van en K. Henkens (2004). 'De verborgen waarde van de oudere werknemer' Bevolking en Gezin 33 (1): 29-6o.

Davis, S., J. Haltiwanger en S. Schuh (1996) Job Creation and Job Destruction Cambridge, MA: MIT Press.

De Nederlandsche Bank (2005) Kwartaalbericht Maart Belemmeringen bij het vergroten van de Nederlandse arbeidsduur.

Deelen, A.P., E.L.W. Jongen en S.S. Visser (2006), 'Employment Protection Legislation', СРВ Document.

Deloitte en Touche (2002/2004) Made in Holland (I-III), Rotterdam: Deloitte en Touche.

Department of Labor (1999) Futurework; Trends and Challenges for work in the 21st Century, website www.dole.gov.

DiPrete, T.A., P.M. de Graaf, R. Luykx, M. Tahlin en H.P. Blossfeld (1997) ‘Collectivist versus individualist mobility regimes? Structural change and job mobility in four countries', American Journal of Sociology 103: 318-358.

Divosa (2006) WWB-monitor 2006, Meer perspectiefvoor mensen, Utrecht: Divosa.

Doeringer, P.B. en M.J. Piore (1971) Internal Labor Markets and Manpower Analysis, Lexington Mass.: Heath Lexington Books.

Dworkin, R. (200o) Sovereign virtue: the theory and practice of equality, Cambridge, MA: Harvard University Press.

EIRR (2006) 'National pension agreement concluded', European Industrial Relations Review, maart 2006: 28-29.

Ekamper, P. (2006) 'Werkende ouderen in België en Nederland - de cijfers', Tijdschrift voor HRM 9, 1: 6-20.

Esping Andersen, G. (red.) (2002) Why We Need a Welfare State, Oxford: Oxford University Press. 
European Commission (2005) European Economy, no. 6/2005.

European Commission (2005a) European Economy, Special Report no 2/ 2005. .

European Commission (2006) Labour Market and Wage Developments in 2005, Special Report no. 4/2006.

Europese Stichting tot verbetering van de levens- en arbeidsomstandigheden (2001), http://www.eurofound.eu.int/publications/files/EFo149NL.pdf.

Evers, G.H.M., A.C.J.M. Wilthagen en I. Borghouts-van der Pas (2004) Best practices in WW-preventie, Tilburg: OSA.

Ewijk, M. van en M. Engelen (2001) Ontslagroutes naar de WW (Research voor Beleid, onderzoek in opdracht van szw).

Ferrera, M, A.C. Hemerijck en M. Rhodes (2003), 'Recasting European Welfare States', blz. 346-366 in J. Hayward en A. Menon (eds.) Governing Europe, Oxford: Oxford University Press.

Förster, M en M.M. d'Ercole (2005) 'Income Distribution in OECD Countries in the Second half of the 1990s', OECD Social, Employment and Migration Papers, Paris: OECD.

Freeman R. (1995) 'The Limits of Wage Flexibility for Curing Unemployment', Oxford Review of Economic Policy 11, 1: 63-72.

Freeman, R.B. en R. Schettkat (2005) 'Jobs and Home Work', Economic Policy, January 2005: 5-50.

Galussák. K. en J. Pavel (2005) 'Does Work Pay? Incidence of Unemployment and Inactivity Traps in the Czech Republic' in European Commission, European Economy, Special Report, no.2/2005, Brussel: EC.

Geerdsen, L.P. (2006) 'Is there a threat effect of labour market programmes? A study of ALMP in the Danish UI system', The Economic Journal 116 (July) 738-750.

Gelderblom, A., J. de Koning en J. Kroes (2003) Leeftijdssamenstelling en bedijfsprestaties, OSA-publicatie A2O1.

Gesthuizen, M. en J. Dagevos (2005) Arbeidsmobiliteit in goede banen: oorzaken van baan- en functiewisselingen en gevolgen voor de kenmerken van het werk, Den Haag: SCP.

Gielen, A. en J. van Ours (2006) 'Ontslag op volgorde. Van dienstjaren naar afspiegeling bij collectief ontslag. Raakt het doel of schieten we mis?’ ESB 91, 4480: 83-85.

Gómez-Salvador, Ramón; Julián Messina \& Giovanni Vallanti ‘Gross Job Flows and Institutions in Europe', Labour Economics, 11 (2004): 469-485.

Goos, M. \& A. Manning (2003) Lousy and Lovely Jobs: The Rising Polarization of Work in Britain, London: Centre for Economic Performance.

Graaf-Zijl, M. de, P. Berkhout, P. Hop en D. de Graaf (2006) De onderkant van de arbeidsmarkt vanuit werkgeversperspectief (SEO-rapport in opdracht van het ministerie van Economische Zaken), A'dam: SEO.

Hall, P. en D. Soskice (2001) Varieties of capitalism. The Institutional; Foundations of Comparative Advantage, New York: Oxford University Press.

Hamel, G. en C.K. Prahalad (1994) Competing for the future, Harvard Bussiness School Press.

Hamermesh, D.S., W.H.J. Hassink en J.C. van Ours (1996) 'Job turnover and Labor turnover: a taxonomy of employment dynamics', Annales d'Economie et de Statistique 41/42: 21-40. 
HBO-raad en RWI (2006), Manifest op initiatief van -, Talent ontwikkelen, talent benutten, Den Haag.

Hebbink, G., M. Kerkhofs, J. Theeuwes en I. Woitiez (1996) Mobiliteit van oudere werknemers, OSA-werkdocument Wi51.

Heckman, J.J. (2006) 'Skill formation and the economics of investing in disadvantaged children’, Science, 5782: 1901-1902.

Heckman, James J. \& A.B. Krueger (2002) Inequality in America, Cambridge (Mass.): MIT Press.

Heijden, H. van der en S. Bochhah (2006) De werkelijkheid van morgen. Zeven megatrends die HRM op zijn kop zetten, Deventer: Kluwer.

Hövels, B., P. den Boer en J. Frietman (1999) 'Formele opleidingskwalificaties en competenties: wat telt voor laagopgeleiden’ Tijdschrift voor Arbeidsvraagstukken 1999 15, 2: 124-134.

ING Bank en M КВ (2005) Bedrijfsoverdracht in het MKB, moeilijkof makkelijk?, 1 oktober 2005.

Jacobs, B. (2004) 'The Lost Race between Schooling and Technology', De Economist 152: 47-78.

Kerhofs, M. (2001) Arbeidsparticipatie van ouderen, OSA-publicatie A181,

Kluve, J. (2006) 'The Effectiveness of European Active Labor Market Policy' Discussion Paper nr. 2018, Bonn: IZA.

Knegt, R. (200o) Evaluatie-onderzoek ontslagvergunningsprocedure RDA (Hugo Sinzheimer Instituut), Amsterdam

Knegt, R. (2005) Ontslagvergoeding en WW (Hugo Sinzheimer Instituut, rapport uitgebracht aan het ministerie van szw).

Kok, J. de (2003) Human Resource Management within Small and medium-Sized Enterprises, Rotterdam: Tinbergen Instituut.

Koning, J. de, G. Bijwaard, A. Gelderblom en J. Kroes (2003) Arbeidsmarkttransities en aanboddiscrepanties, Tilburg: OsA.

Koning, J. de, A. Gelderblom, K. Zandvliet en R. Blanken (2004) Werkt scholing voor werklozen? (onderzoek door SEOR) Den Haag: RWI.

Koning, J. de, J. Kroes, en H. van der Steen, A. (2006) Patronen van werk en gebruik van sociale regelingen, Rotterdam: SEOR.

Korevaar, K. (200o) Strategische arbeidsvoorwaardenvorming, Amsterdam: Mets en Schilt.

Krause, R. (2006) 'The Legal Regulation of Flexicurity’, www.tilburguniversity.nl/flexicurity.

Layard, R. (2005) Happiness, Lessons from a New Science, London: Allen Lane.

Leeuwe, P. van, D. Scheele, J. Theeuwes en T. Woortman (2006), 'Arbeidsdynamiek en vergrijzing', Sociale samenhang in beeld, het SSB nu en straks. Symposium 2005, Den Haag: CBS.

Lommerud, K.E. en S. Vagstad (200o), Mommy Tracks and Public policy: On Self-Fulfilling Prophecies and Gender Gaps in Promotion, CEPR Discussion Paper nr. 2378, CEPR, London.

Meyer, B.D. en D. Holtz-Eakin (red.) (2001) Making Work Pay, The Earned Income Tax Credit and Its Impact on America's Families, New York: Russell Sage.

Ministerie van Sociale Zaken en Werkgelegenheid (2000) De Nederlandse Verzorgingsstaat, Den Haag: Sdu Uitgevers. 
Ministerie van Sociale Zaken en Werkgelegenheid (2002) Naar een werkende reïntegratiemarkt, 28 nov. 2002

Ministerie van Sociale Zaken en Werkgelegenheid (2004) Werkgelegenheid aan de onderkant van de arbeidsmarkt, 20 juni 2004.

Ministerie van Sociale Zaken en Werkgelegenheid (2004a) Nadere Memorie van Antwoord, TK 29513, d.d. 2 december 2004.

Ministerie van Sociale Zaken en Werkgelegenheid (2005) Ontslagstatistiek, Jaarrapportage 2005 , april 2005.

Ministerie van Sociale Zaken en Werkgelegenheid (2005a) 'Motie Bakker besteding en effectiviteit reïntegratiebudget', brief 29 november 2005 .

Ministerie van Sociale Zaken en Werkgelegenheid (2006) Ontwikkelingen en keuzes in het stelsel van werk en inkomen, 28 juni 2006.

Ministerie van Sociale Zaken en Werkgelegenheid (2006a) Kwartaalbericht Arbeidsmarkt mei 2006.

Ministerie van Sociale Zaken en Werkgelegenheid (2006b) Voorjaarsrapportage caoafspraken 2006.

Ministerie van Sociale Zaken en Werkgelegenheid (2006c) WWB: van vliegende start naar blijvend succes, Den Haag: szw.

Moor, I., I. Vossen en M. Arents (200o) Benefit dependency ratios by gender, An international comparison, Rotterdam: NEI.

Mooij, R. de (2006) Reinventing the Welfare State, Den Haag: СРB.

Nagelkerke, A.G., W.G.M. Plessen en A.C.J.M. Wilthagen (red.) (2006) Interne flexibilisering: Juridische en organisatorische randvoorwaarden en ontwikkelingen, Zutphen: Paris.

Nickel, S. (2005) 'The Lower Lecture: Employment, Unemployment and Low Pay' in I. Marx en W. Salverda (red.) Low-wage Employment in Europe, Leuven:Acco.

Oeij, P.R.A., E.P. Miedema en A. Goudswaard (2002) Deflexibilisering van arbeid, Hoofddorp: TNO Arbeid.

Organisatie voor Strategisch Arbeidsmarktonderzoek (2006) Loon en werk na werkloosheid OSA-publicatie A221, mei 2006.

Organisation for Economic Cooperation and Development (1994) The OECD Jobs Study, Parijs: OECD.

Organisation for Economic Cooperation and Development (2003) OECD Employment Outlook, Parijs: OECD.

Organisation for Economic Cooperation and Development (2004) OECD Employment Outlook 2004, Parijs: OECD.

Organisation for Economic Cooperation and Development (2005) OECD Employment Outlook 2005, Parijs: OECD.

Organisation for Economic Cooperation and Development (2006) OECD Economic Outlook 2006, Parijs: OECD.

Organisation for Economic Cooperation and Development (2006a) OECD Economic Surveys, Denmark, Parijs: OECD.

Ours, J. van, J. Veenman en W. Verhoven (2002) Van ouder op kind; Scholing en arbeidsmarktpositie van tweede generatie allochtone jongeren, OSA-publicatie A185.

Pederson, P.J. (2005) 'Unemployment Traps - Marginal Groups in the Danish Labour 
Market' in European Commission, European Economy, Special Report no.

2/2005, Brussel: EC.

Pilat, D. (2005) 'Arbeidsmarktregulering en economische dynamiek', ESB 9o, 4454: 90-91.

Piore, M.J. en C.E. Sabel (1984) The Second Industrial Divide: Possibilities for Prosperity,

London: Basic Books.

Poort, J. et al. (2004) Verplaatsing industrie: hoe erg is het?, SEO-rapport nr. 753, Amsterdam: SEO.

Powell, W.W. (2001) 'The Capitalist Firm in the Twenty-First Century: Emerging Patterns in Western Enterprise', blz.33-68 in P. Dimaggio (ed.) The Twenty-FirstCentury Firm: Changing Economic Organization in International Perspective, Princeton NJ: Princeton University Press.

Praag, B.M.S. van en J.P. Hop (1996) Wmin-Wmax, Een symmetrisch arbeidsmarktmodel, Den Haag: Sdu Uitgevers.

Raad voor Werk en Inkomen (2005) Arbeidsmarktanalyse 2005, Den Haag: RWI.

Raad voor Werk en Inkomen (2005a) Voldoende, nog niet afdoende (onderzoek door Regioplan Beleidsonderzoek), Den Haag: RWI.

Raad voor Werk en Inkomen (2006) Arbeidsmarktanalyse 2006, Den Haag: RWI.

Raad voor Werk en Inkomen (2006a) De route naar resultaat, Reïntegratiemarktanalyse 2006, Den Haag: RWI.

Raad voor Werk en Inkomen (2006b) De regio centraal, Advies over afstemming en samenwerking op regionale arbeidsmarkten, Den Haag: RWI.

Rawls, J. (1971) A theory of justice, Harvard: Harvard University Press.

Rele, H.J.M. ter (2006) Measuring lifetime redistribution and incentive distortions by Dutch collective arrangements, СРВ Discussion Paper (forthcoming).

Rezwani, N. \& P. Hendrix (2002) Verplicht sparen voor het werkloosheidsrisico, Doetinchem: Elsevier.

Salverda, W. (2003) 'Jeugdwerkloosheid revisited: Terug naar de jaren tachtig?’, Tijdschrift voor Arbeidsvraagstukken, 19, 4: 332-349.

Schippers, J., C. Remery en J.P. Vosse (2001) 'Tien jaar flexibilisering tussen onderzoek en beleid', blz. 19-39 in P. Ester, R. Muffels en J. Schippers (red.) Flexibilisering, organisatie en employability, Bussum: Coutinho.

Schmid, G. (1995) 'Is Full Employment Still Possible? Transitional Labour Markets as a New Strategy of Labour Market Policy', Economic and Industrial Democracy, 16, 3: 429-456.

Schmid, G. (2005) Sharing risks; on social risk management and the governance of labour market transitions, Amsterdam: Hugo Sinzheimer-Lecture, 10 november 2005.

Schmid, G. (2006) 'Active Ageing in Europe: Innovating the management of transitions from work to retirement', www.tilburguniversity.nl/flexicurity.

Schreuder, K. (2004) 'The work-family balance in collective agreements. More female employees, more provisions?' Working Paper 2004-28 Amsterdam: AIAS.

Sen, A. (1999) Development and Freedom, New York: Alfred Knopf.

SEOR (2005) Effectiviteit van reïntegratie (onderzoek in opdracht van het ministerie van

SzW) Rotterdam: SEOR.

SEOR (2005a) Patronen van werk en gebruik van sociale regelingen, Rotterdam: SEOR.

SEOR (2006) Effectiviteit van sancties bij arbeidsmarkt- en reïntegratiebeleid (opdrachtgever ministerie van SZW) Rotterdam: SEOR. 
Sociaal-Economische Raad (2002) Werken aan arbeidsgeschiktheid (Advies 02/05).

Sociaal-Economische Raad (2002a) Het nieuwe leren (Advies 02/10).

Sociaal-Economische Raad (2004) Verdere uitwerking WAO-beleid, (Advies 04/O2).

Sociaal-Economische Raad (2005) Ontslagpraktijk en Werkloosheidswet (Advies 05/o6).

Sociaal-Economische Raad (2005a) Toekomstbestendigheid Werkloosheidswet (Advies 05/05).

Sociaal-Economische Raad (2005b) Van alle leeftijden (Advies 05/o2).

Sociaal-Economische Raad (2006) Welvaartsgroei door en voor iedereen (Advies 06/o8).

Sociaal en Cultureel Planbureau (2004), Sociaal en Cultureel Rapport 2004, Den Haag: SCP.

Sociaal en Cultureel Planbureau (2005) Mobiliteit in goede banen. Oorzaken van baan- en functiewisselingen en gevolgen voor de kenmerken van het werk. Den Haag: SCP.

Sociaal en Cultureel Planbureau (2005) Niet-westerse allochtonen met een stabiele arbeidsmarktpositie: aantallen en ontwikkelingen, Den Haag: SCP.

Sociaal en Cultureel Planbureau (2006) Hoge jeugdwerkloosheid onder etnische minderheden, Den Haag: SCP.

Sociaal en Cultureel Planbureau (2006a) Maten voor gemeenten 2006, Den Haag: SCP.

Sol, E. en M. Westerveld (red.) (2005) Contractualism in Employment Services, Den Haag: Kluwer Law I.

Staal, H.W.M.A. (2005) 'Een ideologische worsteling in de zomerreprise’, SMA 60, 10: $455-457$.

Steijn, A.J. en W.H.A. Hofman (1999), 'Zijn lager opgeleiden de dupe van de toestroom van studenten op de arbeidsmarkt? Over verdringing aan de onderkant van de arbeidsmarkt', Tijdschrift voor arbeidsvraagstukken 15, 2: 149-161.

Stichting van de Arbeid (2001) Werk maken van employability, Publicatienr. 2/o1.

Stichting van de Arbeid (2004) Nota inzake de evaluatie Wet flexibiliteit en Zekerheid, Publicatienr. 5/04.

Stichting voor Economisch Onderzoek (2006) Werkt de reïntegratiemarkt?, Amsterdam: SEO.

Storm, S. en C.W.M. Naastepad (2005) 'De schaduwzijde van arbeidsmarktflexibilisering', ESB 90, 4454: 86-89.

Teulings, C.N., E.H.W.M. Vogels en L.G.M. van Dieten (1998) Minimumloon, Arbeidsmarkt en Inkomensverdeling, Den Haag: Sdu Uitgevers.

Tijdens, K. en M. van Klaveren (2004) 'Een onderzoek naar cao-afspraken op basis van de FNV cao-databank en de AWVN-database', A IAS Working Paper 2003-19.

Tijdens, K. en M. van der Meer (200o) 'Flexibele regels: een onderzoek naar de relatie tussen cao-afspraken en het bedrijfsbeleid', A IAs Research Report nr. 5, Amsterdam: AIAS.

TNO (2005) Verraderlijk effectief, Prestatiemeting van reïntegratie en activering deel 2, Hoofddorp: TNO.

Tros, F. (2004) Towards 'flexicurity' in policies for the older workers in EU-countries? Paper Amsterdam: Hugo Sinzheimer Instituut.

Tros, F. (2005) Flexicurity and HR-strategies for the older workers, TLM.NET workingpaper, 2005-13.

Tros, F.H., C.W.G. Rayer en E. Verhulp (2005) 'Flexibiliteit en zekerheid in sociale plannen. Naar meer activering?’ SMA 60 (11/12): 529-538. 
Valk, W.D.M. van der (2006), Scholing in het $M K B$, Zoetermeer: EIM.

Velden, J. van, C. Jansen, I. Vossen en Van der Boom (2006) Ondernemend de uitkering uit, Rotterdam: ECORYS.

Verhulp, E. (2005) 'De opzegtermijnen nader beschouwd', Arbeidsrecht 12 (1): 3-7.

Verhulp, E. (2005a) 'The Evolving Structure of Collective Bargaining in the Netherlands', in S. Sciarra (red.) The Evolving Structure of Collective Bargaining in Europe, Florence: Università di Firenza.

Visser, J. (2001) 'Europa en de cao', AIAS-online research paper.

Visser, J. en M. van der Meer (2007) 'Mobiliteit. Interne arbeidsmarkten en arbeidsverhoudingen - naar een nieuwe dynamiek', blz. 17-64 in D. Scheele, J.J.M. Theeuwes en G.J.M. de Vries (red.), Arbeidsflexibiliteit en ontslagrecht, WRR Verkenning 14, Amsterdam: Amsterdam University Press.

Vlasblom, J. en J. Schippers (2005) Arbeidsmarktconsequenties van kinderen krijgen: een verkenning van de langetermijngevolgen, OSA-publicatie A216.

Vogels, E. (2003) 'Financiële prikkels aan de vraagzijde', ES B 88, 4405: Dio-11.

Vuuren, D. van en R. Euwals (2006), De structurele groei van het arbeidsaanbod op middellange termijn, СРВ Memorandum 155, Den Haag: СРВ.

Wetenschappelijk Instituut voor het CDA (2006) Investeren in participeren, Den Haag: WI CDA.

Wetenschappelijke Raad voor het Regeringsbeleid (1990) Een werkend perspectief, Rapporten aan de Regering nr. 38, Den Haag: Sdu Uitgevers.

Wetenschappelijke Raad voor het Regeringsbeleid (1996) Tweedeling in perspectief, Rapporten aan de Regering nr. 50, Den Haag: Sdu Uitgevers.

Wetenschappelijke Raad voor het Regeringsbeleid (1990) Doorgroei van arbeidsparticipatie, Rapporten aan de Regering nr. 57, Den Haag: Sdu Uitgevers.

Wetenschappelijke Raad voor het Regeringsbeleid (2006) De verzorgingsstaat herwogen. Over verzorgen, verzekeren, verheffen en verbinden, Rapporten aan de Regering nr. 76, Amsterdam: Amsterdam University Press.

Wilthagen, T. (2003) De overgankelijke arbeidsmarkt en het (on)vergankelijke sociaal recht, Tilburg: Universiteitsdrukkerij.

Wilthagen, T. (2004) 'Balancing flexibility and security in European labour markets' SER, Recent Developments in European Industrial Relations.

Wilthagen, A.C.J.M., R. Grim en A.A.G. van Liempt (2006) 'Flexibilisering arbeidsmarkt stagneert', ESB 91, 4483: 154-156.

Zant, W., R. Alessie, R. Oostendorp en M. Pradhan (200o) Flexibiliteit op de Nederlandse arbeidsmarkt: Een empirisch onderzoek op basis van OSA-vraag-en aanbodpanels, OSA-publicatie A175.

Zevenbergen, R.G. van en U.H. Oelen (200o) Het duaal ontslagrecht - beëindiging van arbeidsrelaties in de praktijk (Research voor beleid), Den Haag: Elsevier.

Zijl, M. en M. Budil-Nadvorníková (2001) Atypical labour: flexible labour from the social and employers' point of view. SEO-publicatie nr. 600.

Zijl, M., A. Heyma en G. van den Berg (2004) Stepping-stones for the unemployed: the effect of temporary jobs on the duration until regular work, Amsterdam: SEO.

Zijl, M. en M. van Leeuwen (2004). Tijdelijk werk: tussenstap of springplank. Onderzoek naar het stepping-stone effect van tijdelijke banen, Amsterdam: SEO. 


\section{BIJLAGE I: \\ FLEXIBILITEIT EN ZEKERHEID: WETTELIJKE REGELINGEN}

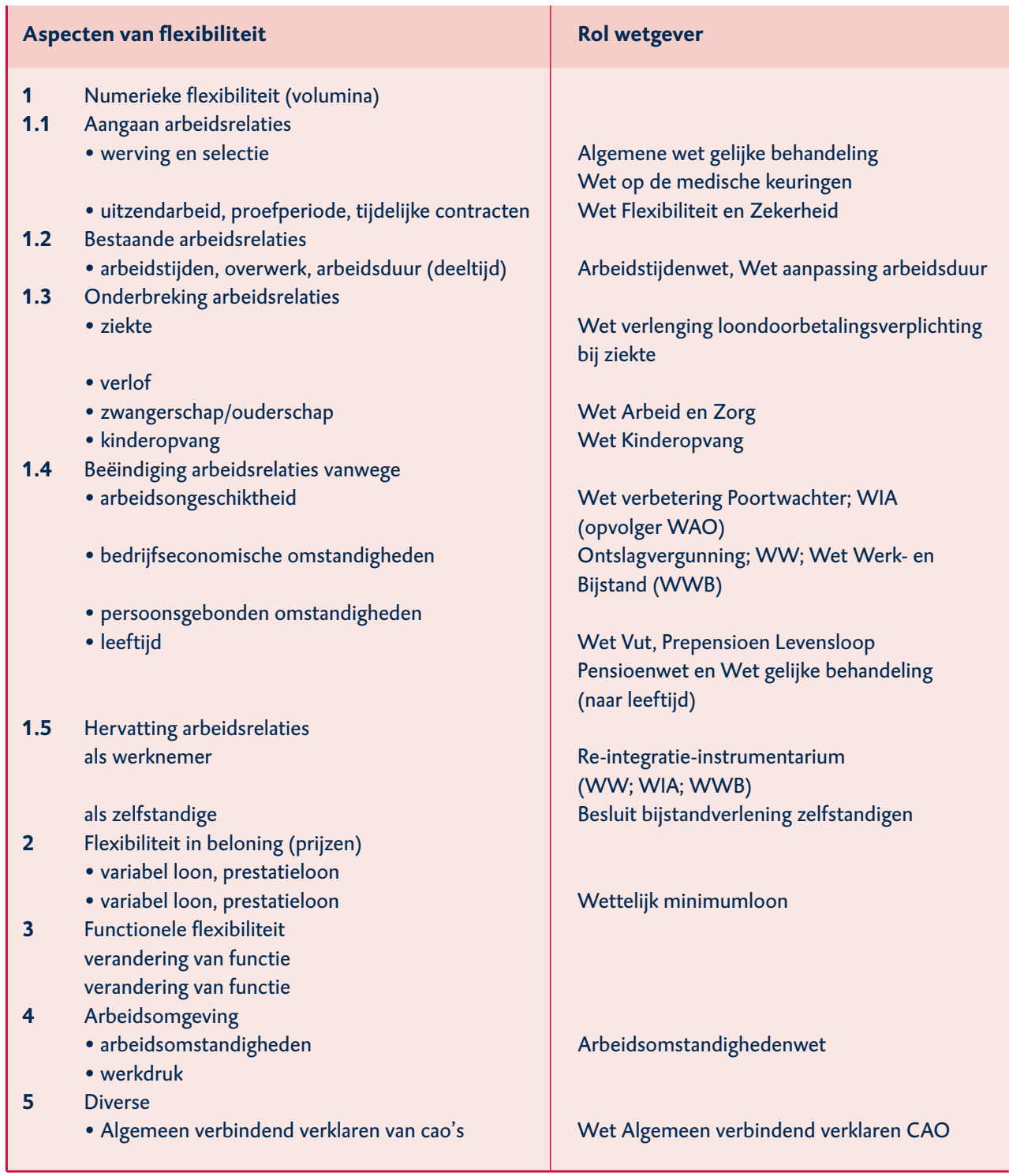




\section{BIJLAGE II: \\ HRM-GESPREKKEN}

Drs. C. Blokland

Drs. A. van Delft

Mr. F.C.A. van Haasteren

Drs. G.J. Haveman

Mevrouw A. Heilbron

De heer J.H.M. Hendriks

Drs. L.M.L.H.A. Hermans

De heer P.W.J. Huiskens

Drs. H.J.M. Knaapen

De heer W.E. Kooijman

De heer A. Kuiper

Drs. J.C. Lammers

Ir. P.H. Paternotte

Mr. A. de Roock

De heer K. Roskam

Mr. H.R. de Ruiter

De heer E. Verboom

Drs. M.F. de Vries

De heer J. Vriesman

Drs. A.J.M. Warnier

Drs. M.C.J. de Wildt

Drs. C.J.F.M. Schaapsmeerders
TNO

Koninklijke Vereniging мкв Nederland

Randstad Holding nv

Corus Strit Products IJmuiden b.v.

Randstad Holding nv

Alysisgroep Zorggroep

Koninklijke Vereniging MкB Nederland

Sara Lee/DE International b.v.

KPN

KLM

Randstad Holding nv

Rabobank Nederland

Sara Lee/DE International b.v.

ABN Amro bank N.V.

Draka Nederland

Heineken Nederlands Beheer

Rabobank Nederland

Ministerie van Binnenlandse Zaken en

Koninkrijkrelaties

Randstad Holding nv

Ministerie van Binnenlandse Zaken en

Koninkrijkrelaties

Qidos

Shell Nederland 


\section{BIJLAGE III: OVERZICHT VAN HET ARBEIDSMARKTBELEID IN NEDERLAND}

Wanneer de overheid zich bemoeit met de inrichting of benutting van de arbeidsmarkt is er sprake van arbeidsmarktbeleid. Met betrekking tot de inrichting kan men denken aan maatregelen die de werking van de arbeidsmarkt verbeteren of het bereik ervan vergroten. Bij een betere benutting gaat het om het stimuleren van bepaalde groepen om op de arbeidsmarkt te participeren. In dit laatste geval spreekt men van een actief of activerend arbeidsmarktbeleid. Zo is in de afgelopen decennia geprobeerd de uitkeringsontvangers waar mogelijk tot deelname aan de arbeidsmarkt te bewegen. In de periode daarvoor ging men uit van de veronderstelling dat de uitkeringsontvangers zelf al het mogelijke zouden doen om tot de arbeidsmarkt toe te treden.

De overgang van deze situatie naar de huidige was verre van eenvoudig. Het vinden van een baan is van vele factoren afhankelijk. Aan de aanbodzijde spelen de motivatie, de arbeidsmarktkwalificaties waarover men beschikt, de veranderingsgeneigdheid en de eisen die men stelt aan een nieuwe baan, een rol. Aan de vraagzijde gaat het om het aanbod van banen en om de voorkeuren van werkgevers. Het hebben van een uitkering, en bijgevolg het niet beschikken over een continue en recente werkervaring, is voor de meeste werkgevers geen aanbeveling als er ook kandidaten zijn, die niet deze achtergrond hebben.

Maar niet alleen de kans op een baan, ook subjectieve voorkeuren en alternatieve dagbestedingen, spelen een rol. Verrichten van vrijwilligerswerk, het opvoeden van kinderen en het verrichten van mantelzorg kan leiden tot vrijstelling van de sollicitatieplicht.

Het actieve arbeidsmarktbeleid grijpt primair aan op uitkeringsontvangers. In het kader van een zo groot mogelijke participatie gaat de aandacht ook uit naar degenen die geen uitkering hebben, maar ook geen betaalde baan. Deze groep kan men evenwel niet aanspreken op basis van hun plichten, omdat zij geen beroep op een uitkering doen. Ook het doorwerken na het 65 ste jaar is een serieus thema, omdat de bijdrage aan de vergrijzing dan dubbel is; enerzijds wordt het financiële draagvlak versterkt, anderzijds wordt het beroep op een overgedragen inkomen geringer.

Ook voert de overheid beleid om de belemmeringen die bij werkgevers bestaan bij het in dienst nemen van uitkeringsontvangers, te mitigeren. Zo is in mei 2006 een brede maatschappelijke campagne gestart om het imago van gedeeltelijk arbeidsgeschikte werknemers te verbeteren. De weerstanden die tegen het in dienst nemen van deze groep bestaan (met name het risico van een verhoogd ziekteverzuim en een lagere productiviteit) blijken in overheersende mate deel uit te maken van het imago van deze groep. Werkgevers die wel gedeeltelijk arbeidsgeschikten in dienst hebben, ervaren deze nadelen in de praktijk niet. 
In onderstaand overzicht is getracht om een aantal maatregelen te benoemen die bijeengenomen een belangrijk deel van het arbeidsmarktbeleid vormt. Wanneer onder arbeidsmarktbeleid wordt verstaan alle maatregelen van invloed op (vergroting van de) arbeidsparticipatie, zou ook het werkgelegenheidsbeleid en daarmee het macro-economische beleid deel hiervan uitmaken. Zou men daarentegen kiezen voor het thans gangbare begrip 'activerend arbeidsmarktbeleid', dat met name de activering van personen betreft die voor een uitkering in aanmerking komen, dan zou de afbakening van wat onder arbeidsmarktbeleid moet worden verstaan, tot een beperking leiden.

In het overzicht worden in de eerste kolom doelgroepen onderscheiden waarop de verschillende maatregelen van toepassing zijn, dan wel, als het gaat om generieke maatregelen, de doelgroepen waardoor deze maatregelen zijn geïnspireerd.

In de tweede kolom gaat het om het aanbrengen van voorwaarden om toetreding tot de arbeidsmarkt mogelijk te maken. Vaak betreft dit het wegnemen van belemmeringen. Veelal zijn deze maatregelen algemeen van aard.

In de derde kolom staan maatregelen die er specifiek op gericht zijn om voor de respectievelijke groepen de overgang naar de arbeidsmarkt te bevorderen.

\section{Tabel B-1 Overzicht arbeidsmarktmaatregelen}

\begin{tabular}{|c|c|c|c|}
\hline Doelgroep & Voorwaarden & $\begin{array}{l}\text { Gerichte onder- } \\
\text { steuning }\end{array}$ & $\begin{array}{l}\text { Begeleid of beschut } \\
\text { werken }\end{array}$ \\
\hline Werkenden & Levensloopregeling & $\begin{array}{l}\text { Wet Vermindering } \\
\text { Afdrachtskorting Onderwijs }\end{array}$ & \\
\hline Vrouwen & $\begin{array}{l}\text { Kinderopvang/ voor- en } \\
\text { naschoolse opvang }\end{array}$ & & \\
\hline Werkzoekenden & & $\begin{array}{l}\text { Sluitende aanpak } \\
\text { Sanctiebeleid } \\
\text { Re-integratietrajecten } \\
\text { Work First }\end{array}$ & \\
\hline Langdurig werklozen & Arbeidskorting & $\begin{array}{l}\text { Re-integratietrajecten } \\
\text { Subsidies }\end{array}$ & \\
\hline $\begin{array}{l}\text { Begeleid of beschut } \\
\text { werkenden }\end{array}$ & & & $\begin{array}{l}\text { WWB/ID- en WIW } \\
\text { WSW } \\
\text { Terugkeerbanen }\end{array}$ \\
\hline Etnische minderheden & Inburgering & & \\
\hline Jongeren & $\begin{array}{l}\text { Kwalificatieplicht } \\
\text { Leer-werkplicht }\end{array}$ & $\begin{array}{l}\text { Task Force Jeugdwerkloosheid } \\
\text { Ontwikkelings- en ervarings- } \\
\text { plaatsen } \\
\text { Leer-/werktrajecten }\end{array}$ & \\
\hline Ouderen & $\begin{array}{l}\text { Maatregelen VUT, } \\
\text { WW en pensioen }\end{array}$ & $\begin{array}{l}\text { Vrijstelling WAO-premie } \\
\text { Hogere arbeidskorting }\end{array}$ & \\
\hline
\end{tabular}


In de vierde kolom staan maatregelen die de tewerkstelling van personen regelen van wie verwacht wordt dat deze niet voor reguliere arbeidsplaatsen in aanmerking kunnen komen.

Hieronder zullen de verschillende regels uit het overzicht worden nagelopen.

Voor werkenden zijn er natuurlijk veel cao-afspraken (zie par. 5.6) die erop gericht zijn de employability van werknemers te bevorderen. Overheidsinterventie ligt hier dan ook minder in de rede. In het kader van de doelstellingen die de overheid heeft met betrekking tot vergroting van de participatie, levenslang leren, en het verenigen van arbeid en zorg ook in die fasen van het leven waarin deze combinatie het meeste van mensen vergt, te weten de zorg voor kinderen, is de levensloopregeling ontworpen. Vooralsnog is zowel de reikwijdte als de feitelijke benutting beperkt, zodat verdere uitwerking nodig zal zijn om de genoemde ambities te kunnen realiseren.

Er zijn thans bijna een miljoen personen zonder eigen inkomen. Het merendeel van deze personen betreffen vrouwen. In niet weinig gevallen zal het gaan om een welbewuste keuze om af te zien van betaalde arbeid, bijvoorbeeld als gevolg van een traditionele rolverdeling of als gevolg van het toekennen van prioriteit aan zorgtaken. In andere gevallen zal het gaan om vrouwen voor wie de beschikbaarheid van een adequate en betaalbare kinderopvang de bepalende factor kan zijn voor arbeidsdeelname. Vandaar dat het beleid ter zake van de kinderopvang hier cruciaal is.

Met de term werkzoekenden worden hier de personen bedoeld die een uitkering ontvangen vanwege inkomensderving als gevolg van afwezigheid van betaalde arbeid. Het gaat dan om mensen in de bijstand, de ww en de gedeeltelijk arbeidsgeschikten. In het kader van de Europese werkgelegenheidsstrategie is de zogenaamde 'sluitende aanpak' ontwikkeld, op basis waarvan iedereen die werkloos wordt binnen afzienbare termijn een aanbod krijgt voor ondersteuning om te reïntegreren. Sanctiebeleid vormt een onmisbaar element van het regime waaronder uitkeringen worden verstrekt, te weten het handhaven van de verplichting om alles te doen om weer zelfstandig in een inkomen te voorzien. Reïntegratietrajecten vormen de belangrijkste vorm van ondersteuning om de herintreding tot de arbeidsmarkt te bevorderen. Work first betreft de door gemeenten geïntroduceerde aanpak waarbij "cliënten direct een training/traject en/of werk aangeboden krijgen in plaats van ...een uitkering”. Het blijkt dat gemiddeld 17 procent van de uitkeringsaanvragen wordt ingetrokken op het moment dat gemeenten direct een tegenprestatie door middel van work first verlangen (Divosa 2006: 11).

Langdurig werklozen zijn niet zelden laagopgeleid en hebben daarom te maken met de armoedeval. De armoedeval wordt verminderd door de arbeidskorting, een fiscale tegemoetkoming waarvan uitsluitend werkenden profiteren. Er zijn naast de algemene arbeidskortingen ook tegemoetkomingen specifiek voor ouderen (vanaf 57 jaar) en voor alleenstaande ouders en tweeverdieners (de zoge- 
naamde aanvullende combinatiekorting voor werkende ouders met kinderen tot 12 jaar; de algemene combinatiekorting voor huishoudens met kinderen jonger dan 12 jaar wordt ook toegekend aan huishoudens waarvan slechts één van de partners werkt en heeft naast een arbeidsmarktmotief derhalve ook een inkomenspolitiek oogmerk.) De armoedeval vormt een disincentive voor deelname aan de arbeidsmarkt. Als deze wordt weggenomen of verminderd, blijft voor veel langdurig werklozen de stap naar een betaalde baan nog steeds erg groot.

De meeste langdurig werklozen maken gebruik van de Wet Werk en Bijstand, op basis waarvan de gemeenten hen reïntegratietrajecten aanbieden. Daarnaast kunnen door gemeenten ook subsidies worden ingezet om werklozen aan werk te helpen. In de afgelopen decennia zijn er vele generieke loonkostensubsidieregelingen geweest die de tewerkstelling van langdurig werklozen voor werkgevers goedkoper maakten (de Wet Vermeend/Moor, de KRA - Kaderregeling Arbeidsinpassing en de Wet Loonkostenreductie Minimumloon). Nadelen van deze generieke subsidies waren dat langdurigheid werd 'beloond' met een subsidie, en voorts dat na enige tijd het verschil van een wel en niet gesubsidieerde maar overigens vergelijkbare werknemer moeilijker te rechtvaardigen is. Al deze subsidieregelingen zijn inmiddels afgeschaft. De SPAK, de Specifieke Afdrachtkorting, die voorziet in een algemene loonkostenverlaging voor de lonen ter hoogte van maximaal 115 procent van het minimumloon, nam deze bezwaren weg. Het algemene karakter verving het op specifieke doelgroepen gerichte karakter, zodat echter per euro subsidieverstrekking de effectiviteit geringer is. Daarom is deze regeling via een fasegewijze afbouw afgeschaft. De subsidies die thans voorkomen zijn ingebed in het fiscale regime en hebben als oogmerk de employability te verhogen, en zijn enerzijds gericht op het behalen van de startkwalificaties, anderzijds gericht op het bevorderen van educatief verlof. Voorts krijgen werkgevers die mbo-leerlingen in de beroepsopleidende leerweg een stageplaats aanbieden een afdrachtvermindering van maximaal $€$ 1.200. Het gaat alleen om scholieren op mbo 1 en mbo 2 niveau. Voor de BBL (Beroepsbegeleidende Leerweg) bedraagt de subsidie $€ 2.500$ per kalenderjaar.

Begeleid werken is gecreëerd voor diegenen die niet over de kwaliteiten beschikken om in reguliere banen tenminste het minimumloon te verwerven. De wsw, de Wet Sociale Werkvoorziening, biedt plaats voor 9o.ooo voltijdbanen en heeft een budget van 2,2 miljard euro. Anders dan begeleid werken kent beschut werken een tijdelijke duur. Beschut werken is een optie voor degenen voor wie de stap naar een reguliere baan, met name door het ontbreken van werkroutine, arbeidsdiscipline en vaardigheden, te groot is. Diverse vormen zijn gepasseerd: de Banenpool, het Jeugwerkgarantieplan, de 'Melkertbanen'; de WIW (Wet Inschakeling Werkzoekenden), en de Instroom-Doorstroom/ID-banen. Afgezien van het vraagstuk van de indicatiestelling levert het beloningsniveau een schier onoplosbaar dilemma op. Beloning op het niveau van het minimumloon roept maatschappelijk verzet op, omdat er geen evident financieel voordeel is ten opzichte van het uitkeringsniveau. Beloning boven dit niveau maakt deze banen dermate aantrekkelijk dat de kans op doorstroom naar reguliere, marktconforme 
banen, heel gering wordt. Inmiddels worden de WIW/ID-banen afgebouwd. Hierdoor blijft voor gemeenten meer geld over voor reïntegratietrajecten. Daarmee is de verantwoordelijkheid voor deze vorm van werkcreatie gedecentraliseerd naar gemeenten. Ook is in voorbereiding een maatregel voor de moeilijkst plaatsbaren, om per 1 januari 2007 twee jaren werkervaring te kunnen opdoen met behoud van uitkering, de zogenaamde terugkeerbanen.

De inschakeling van jongeren op de arbeidsmarkt was taak van de Taskforce Jeugdwerkloosheid, die zich onder meer inzet voor bemiddeling van jongeren en het behalen van startkwalificaties in het beroepsonderwijs. Het wetsvoorstel Leer-werkplicht, waarvan de beoogde ingangsdatum augustus 2007 is, heeft als doel het aantal voortijdige schoolverlaters te verminderen en jongeren actief te houden. Het wetsvoorstel bestaat uit twee delen. De omzetting van de partiële leerplicht voor 17-jarigen in een kwalificatieplicht heeft als doel jongeren een startkwalificatie te laten behalen door introductie van een leerplicht tot 18 jaar. De leerwerkplicht van 18 tot 23 jaar is erop gericht om jongeren aan het werken, leren of een combinatie van beide te krijgen.

De ontwikkelings- en ervaringsplaatsen bieden jongeren tot 23 jaar de gelegenheid om met behoud van uitkering, stageplaatsen te lopen.

Voor ouderen zijn er vele maatregelen genomen, in feite neerkomend op het wegnemen van de inkomenspolitieke begunstiging die voor hun gold, welke evenzovele disincentives bevatte om aan de arbeidsmarkt te blijven deelnemen. De belangrijkste maatregelen betreffen het niet langer fiscaal faciliteren van de vut-regelingen, aanpassingen wetgeving ten aanzien van de pensioenwet, de herintroductie van de sollicitatieplicht en de verkorting van de maximale verblijfsduur in de wW van vijf naar ruim 3 jaren. (Zie voor een overzicht van alle maatregelen, SER 2005: 127-128.) 


\section{RAPPORTEN AAN DE REGERING}

\section{Eerste raadsperiode (1972-1977)}

1 Europese Unie

2 Structuur van de Nederlandse economie

3 Energiebeleid

Gebundeld in één publicatie (1974)

4 Milieubeleid (1974)

5 Bevolkingsgroei (1974)

6 De organisatie van het openbaar bestuur (1975)

7 Buitenlandse invloeden op Nederland: Internationale migratie (1976)

8 Buitenlandse invloeden op Nederland: Beschikbaarheid van wetenschappelijke en technische kennis (1976)

9 Commentaar op de Discussienota Sectorraden (1976)

10 Commentaar op de nota Contouren van een toekomstig onderwijsbestel (1976)

11 Overzicht externe adviesorganen van de centrale overheid (1976)

12 Externe adviesorganen van de centrale overheid (1976)

13 Maken wij er werk van? Verkenningen omtrent de verhouding tussen actieven en niet-actieven (1977)

14 Interne adviesorganen van de centrale overheid (1977)

15 De komende vijfentwintig jaar - Een toekomstverkenning voor Nederland (1977)

16 Over sociale ongelijkheid - Een beleidsgerichte probleemverkenning (1977)

Tweede raadsperiode (1978-1982)

17 Etnische minderheden (1979)

A. Rapport aan de Regering

B. Naar een algemeen etnisch minderhedenbeleid?

Plaats en toekomst van de Nederlandse industrie (1980)

Beleidsgerichte toekomstverkenning

Deel 1: Een poging tot uitlokking (1980)

Democratie en geweld. Probleemanalyse naar aanleiding van de gebeurtenissen in Amsterdam op 30 april 1980

Vernieuwingen in het arbeidsbestel (1981)

Herwaardering van welzijnsbeleid (1982)

Onder invloed van Duitsland. Een onderzoek naar gevoeligheid en kwetsbaarheid in de betrekkingen tussen Nederland en de Bondsrepubliek (1982)

Samenhangend mediabeleid (1982)

\section{Derde raadsperiode (1983-1987)}

Beleidsgerichte toekomstverkenning

Deel 2: Een verruiming van perspectief (1983)

Waarborgen voor zekerheid. Een nieuw stelsel van sociale zekerheid in hoofdlijnen (1985)

Basisvorming in het onderwijs (1986)

De onvoltooide Europese integratie (1986)

Ruimte voor groei. Kansen en bedreigingen voor de Nederlandse economie in de komende tien jaar (1987)

Op maat van het midden- en kleinbedrijf (1987)

Deel 1: Rapport aan de Regering

Deel 2: Pre-adviezen

31 Cultuur zonder grenzen (1987) 


\section{Vierde raadsperiode (1988-1992)}

Activerend arbeidsmarktbeleid (1987)

Rechtshandhaving (1988)

Allochtonenbeleid (1989)

Van de stad en de rand (1990)

Technologie en overheid (1990)

De onderwijsverzorging in de toekomst (1991)

\section{Vijfde raadsperiode (1993-1997)}

Duurzame risico's. Een blijvend gegeven (1994)

Besluiten over grote projecten (1994)

47 Hoger onderwijs in fasen (1995)

De financiering van de Europese Gemeenschap. Een interimrapport (1987)

Overheid en toekomstonderzoek. Een inventarisatie (1988)

Een werkend perspectief. Arbeidsparticipatie in de jaren '90 (1990)

Milieubeleid. Strategie, instrumenten en handhaafbaarheid (1992)

Grond voor keuzen. Vier perspectieven voor de landelijke gebieden in de Europese Gemeenschap (1992)

Ouderen voor ouderen. Demografische ontwikkelingen en beleid (1993)

Belang en beleid. Naar een verantwoorde uitvoering van de werknemersverzekeringen (1994)

48 Stabiliteit en veiligheid in Europa. Het veranderende krachtenveld voor het buitenlands beleid (1995)

Orde in het binnenlands bestuur (1995)

50 Tweedeling in perspectief (1996)

51 Van verdelen naar verdienen. Afwegingen voor de sociale zekerheid in de 21e eeuw (1997)

52 Volksgezondheidszorg (1997)

53 Ruimtelijke-ontwikkelingspolitiek (1998)

54 Staat zonder land. Een verkenning van bestuurlijke gevolgen van informatie- en communicatietechnologie (1998)

\section{Zesde raadsperiode (1998-2002)}

Generatiebewust beleid (1999)

Doorgroei van arbeidsparticipatie (2000)

Ontwikkelingsbeleid en goed bestuur (2001)

Naar een Europabrede Unie (2001)

60 Nederland als immigratiesamenleving (2001)

61 Van oude en nieuwe kennis. De gevolgen van ICT voor het kennisbeleid (2002)

62 Duurzame ontwikkeling. Bestuurlijke voorwaarden voor een mobiliserend beleid (2002)

63 De toekomst van de nationale rechtsstaat (2002)

64 Beslissen over biotechnologie (2003)

65 Slagvaardigheid in de Europabrede Unie (2003)

66 Nederland handelsland. Het perspectief van de transactiekosten (2003)

67 Naar nieuwe wegen in het milieubeleid (2003) 


\section{Zevende raadsperiode (2003-2007)}

Waarden, normen en de last van het gedrag (2003)

De Europese Unie, Turkije en de islam (2004)

71 Focus op functies. Uitdagingen voor een toekomstbestendig mediabeleid (2005)

72 Vertrouwen in de buurt (2005)

73 Dynamiek in islamitisch activisme. Aanknopingspunten voor democratisering en mensenrechten (2006)

$74 \quad$ Klimaatstrategie - tussen ambitie en realisme (2006)

75 Lerende overheid. Een pleidooi voor probleemgerichte politiek (2006)

Rapporten aan de Regering nrs $1 \mathrm{t} / \mathrm{m} 67$ en publicaties in de reeks Voorstudies en achtergronden zijn niet meer leverbaar. Alle studies van de WRR zijn beschikbaar via de website www.wrr.nl.

Rapporten aan de Regering nrs $68 \mathrm{t} / \mathrm{m} 76$ zijn verkrijgbaar in de boekhandel of via Amsterdam University Press, Herengracht 221, 1016 BG Amsterdam (www.aup.nl). 


\section{VERKENNINGEN}

\section{Zevende raadsperiode (2003-2007)}

1 Jacques Pelkmans, Monika Sie Dhian Ho en Bas Limonard (red.) (2003) Nederland en de Europese grondwet

2 P.T. de Beer en C.J.M. Schuyt (red.) (2004) Bijdragen aan waarden en normen

3 G. van den Brink (2004) Schets van een beschavingsoffensief. Over normen, normaliteit en normalisatie in Nederland

4 E.R. Engelen en M. Sie Dhian Ho (red.) (2004) De staat van de democratie. Democratie voorbij de staat

5 P.A. van der Duin, C.A. Hazeu, P. Rademaker en I.J. Schoonenboom (red.) (2004) Vijfentwintig jaar later. De Toekomstverkenning van de WRR uit 1977 als leerproces

6 H. Dijstelbloem, P.L. Meurs en E.K. Schrijvers (red.) (2004) Maatschappelijke dienstverlening. Een onderzoek naar vijf sectoren

7 W.B.H.J. van de Donk, D.W.J. Broeders en F.J.P. Hoefnagel (red.) (2005) Trends in het medialandschap. Vier verkenningen

8 G. Engbersen, E. Snel en A. Weltevrede (2005) Sociale herovering in Amsterdam en Rotterdam. Eén verhaal over twee wijken

9 D.J. Wolfson (2005) Transactie als bestuurlijke vernieuwing. Op zoek naar samenhang in beleid en uitvoering

10 Nasr Abu Zayd (2006) Reformation of Islamic Thought. A Critical Historical Analysis

11 J.M. Otto (2006) Sharia en nationaal recht. Rechtssystemen in moslimlanden tusssen traditie, politiek en rechtsstaat

12 P.L. Meurs, E.K. Schrijvers en G.H. de Vries (2006) Leren van de praktijk. Gebruik van lokale kennis en ervaring voor beleid

13 W.B.H.J. van de Donk, A.P. Jonkers en G.J. Kronjee (red.) (2006) Geloven in het publieke domein. Verkenningen van een dubbele transformatie

14 D. Scheele, J.J.M. Theeuwes, G.J.M. de Vries (red.) (2007) Arbeidsflexibiliteit en ontslagrecht

Alle Verkenningen zijn verkrijgbaar in de boekhandel of via Amsterdam University Press, Herengracht 221,

1016 BG Amsterdam (www.aup.nl). 


\section{WEBPUBLICATIES}

\section{Zevende raadsperiode (2003-2007)}

WP 1 Opvoeding, onderwijs en jeugdbeleid in het algemeen belang

WP 2 Ruimte voor goed bestuur: tussen prestatie, proces en principe

WP 3 Lessen uit corporate governance en maatschappelijk verantwoord ondernemen

WP 4 Regulering van het bestuur van maatschappelijke dienstverlening: eenheid in verscheidenheid

WP 5 Een schets van het Europese mediabeleid

WP 6 De regulering van media in internationaal perspectief

WP 7 Beleid inzake media, cultuur en kwaliteit: enkele overwegingen

WP 8 Geschiedenis van het Nederlands inhoudelijk mediabeleid

WP 9 Buurtinitiatieven en buurtbeleid in Nederland anno 2004: analyse van een veldonderzoek van 28 casussen

WP 10 Geestelijke gezondheid van adolescenten: een voorstudie

WP 11 De transitie naar volwassenheid en de rol van het overheidsbeleid: een vergelijking van institutionele arrangementen in Nederland, Zweden, Groot-Brittanië en Spanje

WP 12 Klassieke sharia en vernieuwing

WP13 Sharia en nationaal recht in twaalf moslimlanden 


\section{Investeren in werkzekerheid}

De arbeidsmarkt van de toekomst zal veel dynamischer worden vanwege de toenemende globalisering en snellere veranderingen van productieprocessen en -technieken. Het begrip van een 'vaste baan voor het leven' zal verdwijnen en dient te worden vervangen door het vertrouwen in werkzekerheid bij werknemers die met steeds meer flexibiliteit op de arbeidsmarkt te maken krijgen. Om dit te bereiken is een kanteling van het denken over werkzekerheid nodig, zo meent de Wetenschappelijke Raad voor het Regeringsbeleid (WRR). Werknemers moeten een op positieve ervaringen gestoeld vertrouwen krijgen dat zij op de arbeidsmarkt steeds weer hun weg zullen weten te vinden. Zij zullen daarvoor beter moeten worden toegerust. Een herijking van de bestaande arbeidsmarktinstituties is nodig, evenals een concretisering van het begrip 'een leven lang leren'. De WRR adviseert in dit rapport de regering en sociale partners om wederzijds verplichtende afspraken te maken, waarbij werkgevers de plicht aanvaarden dat werknemers de gelegenheid krijgen zich toe rusten voor een flexibelere inzet door middel van het verwerven van kennis en vaardigheden waardoor ook andere functies binnen hun bereik komen. Hiermee wordt niet alleen een flexibele inzet binnen het eigen bedrijf bevorderd, maar ook bij andere bedrijven. Daartegenover staat de plicht van de werknemer om hiervan gebruik te maken. Deze afspraken zullen moeten worden vastgelegd in cao's en mogelijk een wettelijke basis krijgen. Voor kwetsbare groepen op de arbeidsmarkt worden extra maatregelen bepleit om het verkrijgen van werkzekerheid te ondersteunen.

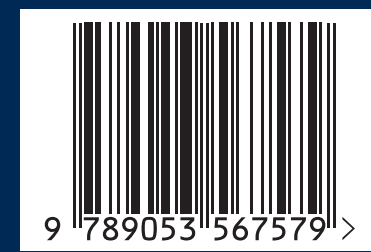

ISBN 978-90-5356-757-9 